\title{
AD-A276 654
}

|lon
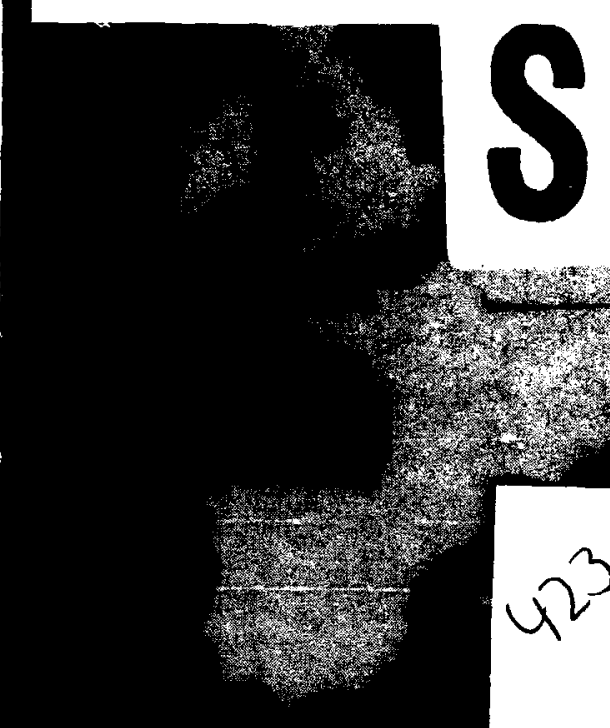

ELEC.TE

MAR 081994

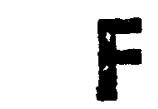

F
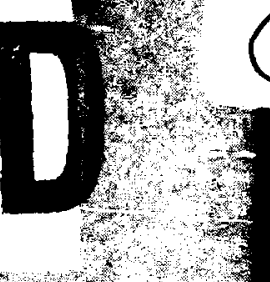

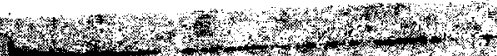

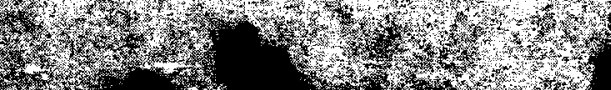

?.

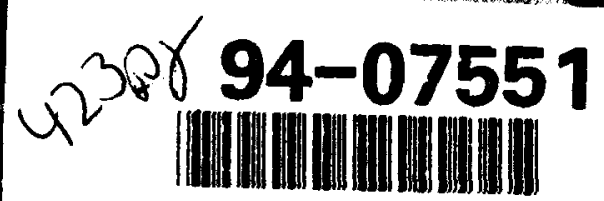

\section{THEHELSINKI PROCESS NEGOTIATING SECURITY AND COOPERATION IN EUROPE}

This document has been approved for public selecse and sala; to distribution is usidmited

\section{JOHN FRY}




$$
\begin{gathered}
\text { Best } \\
\text { Available } \\
\text { Copy }
\end{gathered}
$$




\section{The Helsinki Process Negotiating Security and Cooperation in Europe}
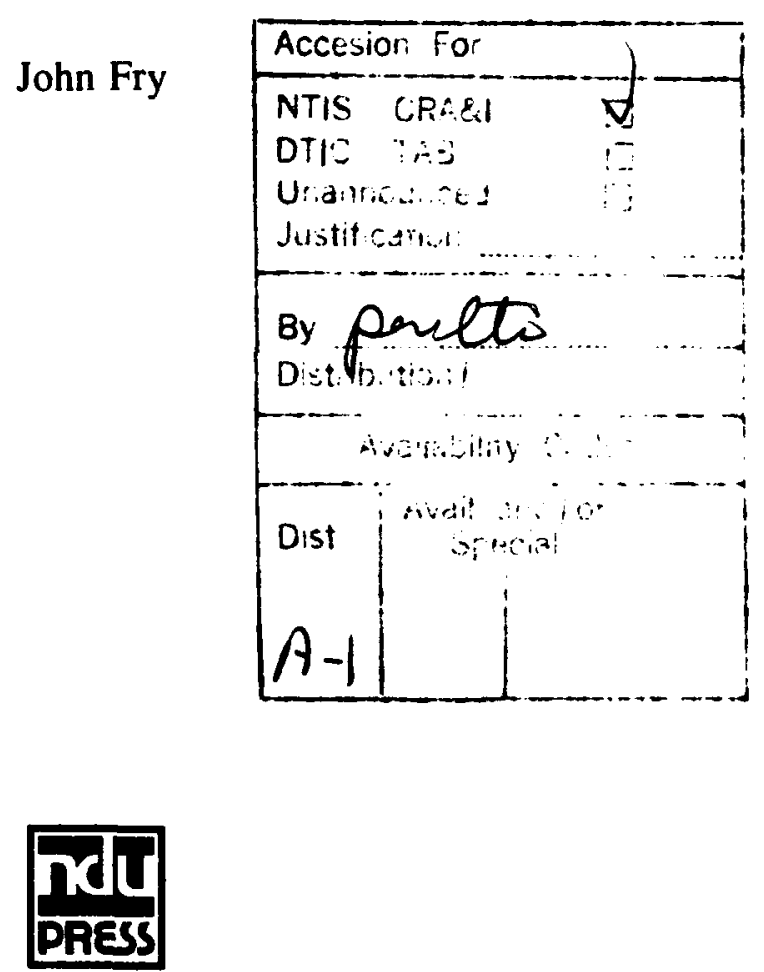

1993

National Defense University Press

Washington, DC 


\section{National Defense University Press Publications}

To increase general knowledge and inform discussion, NDU Press publishes monographs, proceedings of University-sponsored symposia, and hooks relating to U.S. national security, especially to issues of joint, combined, or coalition warfare, peacekeeping operations, and national strategy. The Press occasionally publishes out-of-print defense classics, historical works, and other especially timely or distinguished writing on national security, and it is the home of JFQ: Joint Force Quarterly, a forum for examining joint and combined warfare and exchanging ideas of importance to all services.

Opinions, conclusions, and recommendations expressed or implied in this volume are solely those of the author and do not necessarily represent the views of the National Defense University, the Department of Defense, or any other government agency. Cleared for public release; distribution unlimited.

NDU Press publications are sold by the US Government Printing Office. For ordering information, call (202) 783-3238 or write to Superintendent of Documents, US Government Printing Office. Washington, DC 20402.

Editorial services for this book were provided by Peggy Miller Associates. Washington, DC.

\section{Library of Congress Cataloging-in-Publication Data}

Fry, John, 1926-

The Helsinki process: negotiating security and cooperation in Europe / John Fry.

p. $\mathbf{c m}$.

Includes bibliographical references and index.

1. Conference on Security and Cooperation in Europe (1972: Helsinki, Finland) 2. European cooperation. 3. Security, International. I. Title.

JX1393.C65F5447 1993

$327.1^{\prime} 7^{\prime} 094$ dc20

93-38772

First printing, December 1993 
To CAREER AMBASSADOR GeORGE S. VeST,

\section{FIRST US REPRESENTATIVE TO THE CONFERENCE ON} SECURTTY AND COOPERATION IN EUROPE, WHO ADDED HIS TOUCH OF GENIUS

TO THE HELSINKI PROCESS 


\section{Contents}

Foreword $\quad x i$

Chronology of the Helsinki Process xiii

1. Agreement at Helsinki 3

Evolution of the Conference / East and West Objectives / The Final Act

2. Test of Wills at Belgrade 23

Spotlight on Human Rights / US Helsinki Commission / The Helsinki Monitoring Groups / A Presidential Initiative / Escaping Forward / The Yellow Book / A Surprise Appointment / A Question of Style / Balanced Progress at Stake / More Than a Goalless Draw

3. Crisis at Madrid 43

Few Successes, Many Failures / The Helsinki Lobby / A Difficult Meeting / Reviewing the Record / On Principles and Security / On Trade and Science / On Human Contacts, Information, and Culture / A Media Event / New Proposals / The Worst Crisis / End Game / A Fairly Substantial Document

4. Progress at Stockholm 79

Four Proposals / The Long Stall / A Significant Agreement

5. Ottawa, Budapest, and Bern 93

Ottawa on Human Rights / Budapest on Culture / Bern on Human Contacts

6. Inspiration for Change at Vienna 105

A Promising Start / Critical Review / Media Diplomacy/ More Proposals / Still More Proposals / Glasnost 
and Perestroika / Western Security / A Growing Malaise / A Successful Conclusion

7. Gaining Momentum 143

Military Security / The Human Dimension / Charter of Paris for a New Europe

8. The CSCE Pillar of Europe 165

Appendix A. The Three Baskets 175

B. The Helsinki Final Act 179

C. The Madrid Concluding Document 269

D. The Concluding Document of the Vienna Follow-Up Meeting 305

E. Charter of Paris for a New Europe 359

Notes 385

Index 401

The Author 411 


\section{Foreword}

For years to come historians will debate how the Cold War was won, what effect the Strategic Defense Initiative may have had, and whether the Chernobyl disaster hastened its end. Some may conclude that the Cold War was an extended contest of fundamental beliefs. Even in the civilized context of the series of meetings begun in Helsinki as the "Conference on Security and Cooperation in Europe" that became known as the "Helsinki Process," the conflict was intense. This book is a comprehensive account of that process, its formal agreements, and its place in promoting stability in Europe.

When the first phase of negotiations opened in 1972, the Western European governments sought progress toward a reunified Europe, US negotiators pursued mutual arms reductions, and the communist bloc had its own goals. But, according to the author, it was the notion of universal human rights that, at successive meetings in various European cities, became the motive force for change. As John Fry relates, the sessions were often extended shouting matches, pitting one group's ideology against another's. But like the proverbial water dripping on a stone, Western values gradually eroded the resistance of the communist bloc. As general agreement on human rights solidified, negotiators were also able to achieve cooperation on a range of military, security, and economic issues.

The Helsinki Process not only produced standing agreements but created an acceptable framework for 
dialogue on such current issues di easing the security concerns of Eastern Europe and the former Soviet republics. The Helsinki Process-which the author calls that "steady drumbeat of respect for human rights"has earned a place in history as one of the most successful campaigns of the Cold War.

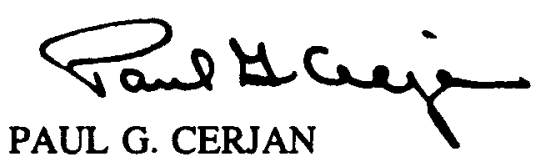

Lieutenant General, US Army

President, National Defense University 


\section{Chronology of the Helsinki Process}

Final Act signed, Helsinki, August 1975

First Follow-Up Meeting, Belgrade, October 1977-March 1978

Experts Meeting on Peaceful Settlements, Montreux, December 1978

Experts Meeting on Mediterranean Cooperation, Valletta, February-March 1979

Scientific Forum, Hamburg, February-March 1980

Second Follow-Up Meeting, Madrid, November 1980-September 1983

Conference on Confidence- and Security-Building Measures and Disarmament (CDE), Stockholm, January 1984-September 1986

Experts Meeting on Peaceful Settlements, Athens, March 1984

Seminar on Mediterranean Cooperation, Venice, October 1984

Experts Meeting on Human Rights, Ottawa, May-June 1985

Commemorative Meeting, Helsinki, August 1985

Cultural Forum, Budapest, October-November 1985

Experts Meeting on Human Contacts, Bern, April-May 1986

Third Follow-Up Meeting, Vienna, November 1986-January 1989

Negotiations on Confidence- and Security-Building Measures, Vienna, March 1989

Information Forum, London, April-May 1989 
Conference on the Human Dimension, Paris, May-June 1989

Meeting on the Protection of the Environment, Sofia, October-November 1989

Conference on Economic Cooperation in Europe, Bonn, March-April 1990

Conference on the Human Dimension, Copenhagen, June 1990

Meeting on the Mediterranean, Palma de Mallorca, September-October 1990

Meeting of Foreign Ministers, New York, October 1990

Summit Meeting of Heads of State and Government, Paris, November 1990

xiv 
The Helsinki Process 
One

Agreement at Helsinki

THE 1975 HELSINKI CONFERENCE on Security and Cooperation in Europe has served the twin goals of continued peace and greater freedom in Europe. The followup meetings from 1975 through 1990, part of the continuing Helsinki Process, form the subject of this book.

\section{Evolution of the Conference}

The genesis of the idea behind the Helsinki Process occurred two decades before the Helsinki Conference itself. Alarmed by the prospect of West Germany joining the North Atlantic Treaty Organization, and worried about his government's inability to secure Western agreement on German neutrality, Soviet Foreign Minister Vyacheslav Molotov proposed a major conference on security in Europe at a Foreign Ministers' meeting of the Four Great Powers in Berlin in February 1954. The Soviet proposal called for a 50-year treaty of collective security exclusively among European states, relegating the United States to observer status. US Secretary of State John Foster Dulles, a self-declared "observer," immediately criticized the proposed treaty as in reality a replacement of the North Atlantic Treaty. 1 The French and British objected to the propr al as well, leading to its ultimate rejection. ${ }^{2}$ 


\section{THE HELSINKI PROCESS}

When the four Foreign Ministers met again in 1955, Foreign Minister Molotov presented a revised version of the treaty, intended to replace all existing military alliances and providing for US participation. Lacking essential provisions for "the reunification of Germany by means of free elections," the revised version of the proposed treaty was similarly rejected. A decade would pass without further Great Powers' efforts toward agreement on Germany or European security. ${ }^{3}$

By the mid 1960s, the vivid scenes of Soviet repression in Hungary in 1956 began to fade. In his March 1966 address to the 23d Party Congress, General Secretary Leonid Brezhnev revived the conference idea and urged the convocation of an all-European meeting to discuss questions of security and cooperation. About this time, changes in the political climate of Europe were creating the basis for improved dialogue with the East. The Federal Republic of Germany, for example, had adopted a less restrictive policy toward Eastern Europe, opened diplomatic relations with Romania, and established a trade mission in Czechoslovakia.4

A 1967 NATO study, "The Future Tasks of the Alliance" (the Harmel Report, named after Belgian Foreign Minister Pierre Harmel), affirmed that the NATO allies wanted a "more stable relationship" with Eastern Europe and would prepare for the time when fruitful discussions "to achieve a just and stable order in Europe, overcome the division of Germany, and foster European security" might be possible. 5 Soon thereafter, however, the Soviet invasion of Czechoslovakia stilled NATO's good intention of commencing 
discussions of mutual and balanced force reductions with the East.

The potential for widening dissent in Eastern Europe and deteriorating relations with China contributed to a sense of urgency in the Soviet Union, which inspired new Soviet efforts to negotiate security and cooperation with the West. The Warsaw Pact meeting in March 1969, in Budapest, formally proposed a European security conference to "strengthen political, economic and cultural links." 6 Soviet Ambassador Anatoly Dobrynin in Washington lost no time in assuring the White House the United States would indeed be invited this time to participate in the conference.

The Ministers of the North Atlantic Council at their next meeting decided "to explore with the Soviet Union and the other countries of Eastern Europe which concrete issues best lend themselves to fruitful negotiation and an early resolution." 7 With prospects for a meeting brightening, the Finnish Government sent a memorandum to all European countries, the United States, and Canada, offering Helsinki as the conference site.

In December 1969, NATO's formal response to the Warsaw Pact initiative agreed in principle to discuss European security issues at a conference with the East. This reply made the twin goals of achieving a modus vivendi between the two parts of Germany and "improving the situation with respect to Berlin and free access to the city" preconditions for the talks. It also renewed NATO's interest in discussing mutual and balanced force reductions and advanced the novel idea that economic, technical, and cultural exchanges between interested countries could bring not only 


\section{THE HELSINKI PROCESS}

mutual benefit and understanding, as proposed by the Soviet Union and the countries of Eastern Europe, but also that "more could be achieved by freer movement of people, ideas and information between the countries of East and West." 8 The response represented the first movement toward a Western strategy for the Helsinki Conference.

From this point, with both East and West accepting the reality of a divided Europe, progress toward a European security conference accelerated with impetus from both sides. In 1970, the Federal Republic of Germany signed a treaty with the Soviet Union to "regard the frontiers of all States in Europe as inviolable" and with Poland normalizing relations and relinquishing any claim to recover territories East of the Oder-Neisse line.9 The next year the Four Powers (United States, Soviet Union, United Kingdom, and France) signed the Quadripartite Agreement on Berlin, freeing the movement of people and goods between the Western sectors of Berlin and West Gerniany, thus fulfilling one NATO prerequisite for undertaking the "Conference on Security and Cooperation in Europe (CSCE).," 10

At the Moscow summit meeting in May 1972, President Richard Nixon and General Secretary Brezhnev endorsed the principles on which the conference would be based.11 With reluctance on both sides, the Soviets agreed to enter into Mutual and Balanced Force Reduction negotiations, and the United States agreed to participate in the CSCE. The joint support of these leaders encouraged the Finnish Government to issue formal invitations to the European nations, less Albania, and the United States and Canada (35 in all) 
to attend the opening phase of the Conference in Helsinki, commencing November 22, 1972.12

Shortly thereafter, the second NATO condition was met when the two Germanys signed a treaty outlining the basis of their relationship. Reaffirming the "inviolability now and in the future of the border existing between them," the Federal Republic and the German Democratic Republic pledged to "work together to promote peaceful relations between the European States and contribute to security and cooperation in Europe." 13 This treaty set the final stage for the Helsinki Conference.

\section{East and West Objectives}

During the two decades of East-West diplomacy since the Soviets advocated the idea of a European security conference, individual states and alliances had refined their ideas of what they wanted the Conference to achieve. 14 The Soviet Union wanted to gain influence in Western Europe through a security structure outside the Warsaw Pact and NATO. The USSR also wanted to legitimize the political status quo and the frontiers of Central and Eastern Europe, which had been in part created by Soviet wartime and postwar aggrandizement. A third Soviet interest, and one less well understood than the others, was to create a framework for controlling East-West contacts, which could contain such political experiments in Eastern Europe as those which provoked the Soviet invasion of Czechoslovakia in 1968. There was unrest in Poland that year and again in 1970. Romania had elected a semi-independent foreign policy and Hungary was increasingly going its own way domestically. There was a strong East 


\section{THE HELSINKI PROCESS}

European desire for economic and technological advances, one which the Soviet Union, with its stagnant economy, was decreasingly able to meet. Yet Moscow realized that to leave such desire unmet might cause further unrest.

A leading US authority on the Helsinki Process, Ambassador Warren Zimmermann, believes the Brezhnev regime took a calculated risk by deciding to let the East Europeans turn West for those economic and technological needs which it could not or would not supply itself. Moscow sought to constrain the process by confining it within a "CSCE framework"- that is by limiting Eastern Europe's increased contacts with the West to those possible under the Conference on Security and Cooperation in Europe. Accordingly, the Soviet Helsinki proposal was heavy on economic and technological exchange within a pan-European framework.

The chief US interest in the Conference was to see that it supported mutual force reductions and USSoviet strategic arms limitations. Secretary of State Henry Kissinger saw the Helsinki Conference as part of a network of negotiations between the United States and USSR in which he was prepared to trade a strong US position in the Conference for Soviet concessions in areas he considered more important.

Western Europe held a much deeper interest in the CSCE. West Europeans wanted to begin to remove the barriers that divided Europe-the walls, barbed wire, and weapons-and to unify the continent once again. The unification factor was especially strong in the Federal Republic of Germany, which was from the outset the European NATO member most commit- 
ted to the Helsinki Process. The West Europeans, even before the United States, recognized the importance of the freer movement of people, ideas, and information as means for increasing contacts across the barriers, and thus wanted to add to the original Soviet agenda, which was primarily political and economic.

The East European satellite states had the biggest stake of all in the Conference. Their hard-line governments and especially their people saw Helsinki as a way to escape the Cold War and to gain more flexibility in relationships with both the Soviet Union and the West. Most of all, they valued the opportunities for increased economic and cultural contacts with the West promised by the Conference.

Although the neutral and nonaligned European states generally share the principles and concepts of other West Europeans, they had certain objectives of their own at the Conference. Having been left out of the Mutual and Balanced Force Reduction talks between the military alliances beginning in Vienna on October 30, 1973, their first concern was adequate security content of the Conference. They also sought a successful meeting with binding followup provisions assuring them a continuing voice in pan-European affairs. 15

The neutral and nonaligned states deserve great credit for their conciliatory role in advancing the essential compromises on human rights and freer movement which made final agreement possible. The full text of the conference agreement, entitled the "Final Act," is included for reference in appendix B. 


\section{THE HELSINKI PROCESS}

\section{The Final Act}

The negotiation of the Final Act lasted roughly two years. Once the Westem states had agreed to the principle of inviolability of frontiers, the Soviets not long afterwards yielded on human contacts and promised freer movement of people and information, including family reunification. On the eve of the Helsinki summit, Americans were more concerned with frontiers than with human rights. Strident domestic opposition to the Conference emerged over what was seen as de facto recognition of post-World War II Euronean frontiers, including incorporation of the formerly independent countries of Estonia, Lithuania, and Latvia into the Soviet Union in 1940. Opposition was especially intense among Soviet and East European emigre groups in the United States, whose most vocal spokesman was Aleksandr Solzhenitsyn. President Gerald Ford assured his critics before taking off for Europe the United States had "never recognized the Soviet incorporation of Lithuania, Latvia, and Estonia and is not doing so now." 16 In response to a Wall Street Journal editorial headline, "Jerry, Don't Go," the President told the leaders of East European ethnic groups at the White House he would rather read that, than headlines all over Europe saying, "United States Boycotts Peace Hopes." 17

Among these groups the President tried to dispel honest doubts about the Conference by casting it in a more humane light. The prospect that adversarial governments could agree, even on paper, to such principles as increased human contacts and exchanges, improved conditions for international journalists, reunification of families and international marriages, freer 
Europe, 1984

....tente

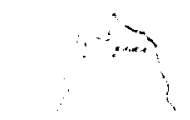

SWFDEN

$$
\because \text { ine. }
$$$$
\text { , } \quad \therefore \times *
$$

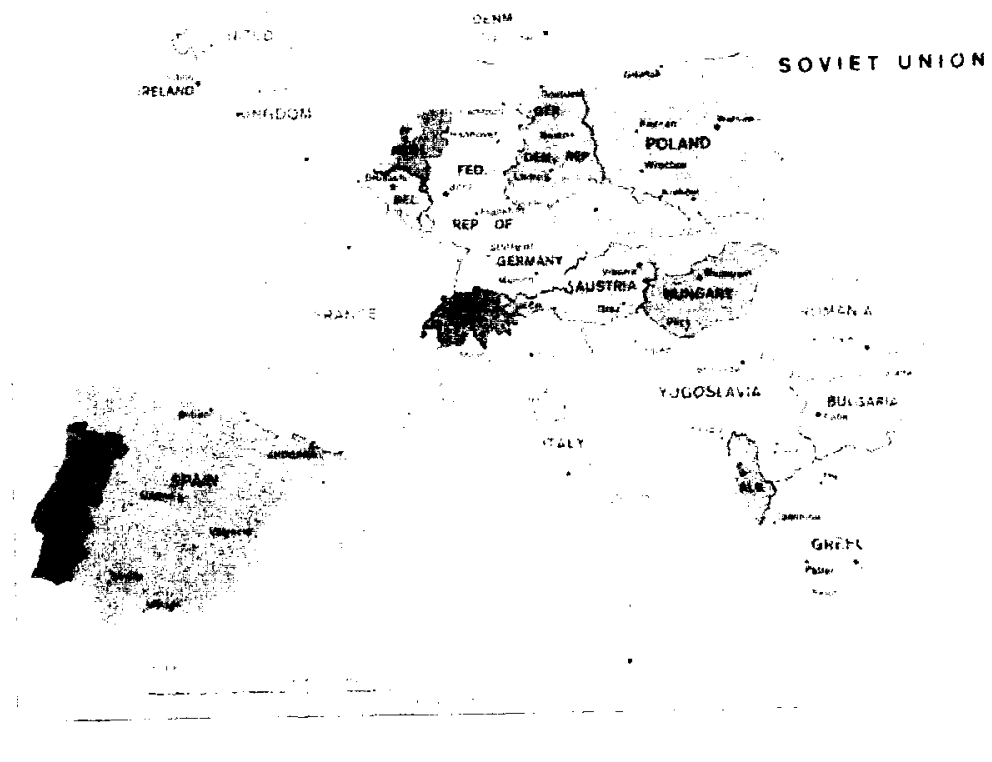

sens...

+es: 


\section{THE HELSINKI PROCESS}

flow of information and publications, and increased tourism and travel seemed to him a development well worthy of private and public encouragement by the United States.

In his address to the heads of state and government assembled in Helsinki, President Ford recognized the deep devotion Americans have to human rights and freedom and the pledges the Conference had made to the freer movement of people, ideas, and information. In concluding his remarks that day, however, he anticipated the troubles ahead in implementing these visionary accords: "History will judge this Conference not by what we say here today, but by what we do tomorrow-not by the promises we make, but by the promises we keep." 18

On August 1, 1975, Gerald Ford, Pierre Trudeau, and the leaders of 33 European states, including Leonid Brezhnev, Helmut Schmidt, Harold Wilson, and Valery Giscard d'Estaing signed the Final Act of the Conference on Security and Cooperation in Europe in Helsinki's Finlandia Hall. When the leaders had put their names to the Final Act, they had consented to two resolutions. The first committed the signatories to implement its provisions "unilaterally, bilaterally and multilaterally." The second committed them to continue the multilateral process by proceeding with a "thorough exchange of views" on the Final Act's implementation through meetings among their representatives for this purpose.

The Helsinki agreement can, therefore, be viewed in two distinct ways: as a permanent document, establishing a framework for guiding relations between the participating states in all fields, and as a process of 
dialogue and consultation. The Final Act did not specify terms under which notice of withdrawal might be served, nor did it set out procedures by which its provisions might be renegotiated at a later date. The Act is not a treaty defined by international law, but rather a set of principles of behavior for states toward their own citizens as well as other states. Jonathan Luxmoore called it the "classic statement of the purposes and parameters of detente." 19

The vast scope of the Final Act ranges from principles on sovereign equality and peaceful settlement of disputes to guidelines on teaching methods and encouraging the study of foreign languages. Its provisions fall naturally into three baskets, so called because delegates literally put their conference proposals into politi$\mathrm{cal} / \mathrm{military}$, economic, and cultural/humanitarian baskets. (See appendix A for a listing of the contents of each basket.) Basket I contains 10 generally accepted principles of interstate behavior drawn from United Nations declarations, including the inviolability of frontiers, respect for human rights, nonintervention in internal affairs and refraining from the threat or use of force. With respect to the inviolability of frontiers and the territorial integrity of states, "frontiers can be changed in accordance with international law, by peaceful means, and by agreement."

The most controversial of these guiding principles is Principle VII. "Respect for human rights and fundamental freedoms, including the freedom of thought, conscience, religion, or belief." This Principle requires the states to "respect human rights and fundamental freedoms, without distinction as to race, sex, language, or religion," to "promote and encourage the effective 


\section{THE HELSINKI PROCESS}

exercise of civil, political, economic, social, cultural, and other rights and freedoms," to "recognize and respect the freedom of the individual to profess and practice . . . religion or belief in accordance with dictates of his own conscience," and to recognize the universal significance of human rights and fundamental freedoms in ensuring friendly relations and cooperation among all states; and it confirms "the right of the individual to know and act upon his rights and duties in this field."

Because the subject of "human rights" has produced such acrimony throughout the Helsinki Process, the question naturally arises, What are human rights? In his Helsinki address, President Ford drew from the Declaration of Independence to express the American view of human rights as the "inalienable rights to life, liberty and the pursuit of happiness." Writing in "Human Rights in Our Times," James Ring Adams concludes the "theory of human rights embedded in the Final Act is primarily that of the Western liberal tradition." 20 But in relying on the UN Universal Declaration of Human Rights for the text of Principle VII, Helsinki negotiators equated economic, social, and cultural rights with civil and political rights. While Americans tend to think of human rights in civil and political terms, East European delegates usually view them in economic, social, and cultural terms, this being the basis for their most virulent attacks on the West. (The interpretation of an individual's civil, political, economic, and social rights-debated at length at the Human Rights Conference in Ottawa-is discussed in Chapter 5.) 
To thwart any possible claim of precedence among the 10 principles-for example, that nonintervention in internal affairs (Principle VI) belongs ahead of respect for human rights (Principle VII)the Final Act states that all the principles are of "primary significance," giving each of the 10 equal weight and importance. Similarly, the provisions of the Final Act are indivisible. No one section of the Act is to be emphasized at the expense of another and, conversely, no area is to be ignored or relegated to a lower status. The Helsinki Process is thus intended to achieve even progress among the three baskets toward its political-military, economic, and humanitarian goals.

The first basket also includes confidence-building measures to promote European security, including prior notification of major military maneuvers exceeding a total of 25,000 troops and other military maneuvers. prior notification of major military movements, and the exchange of observers.

To "promote economic and social progress" and to reinforce the "peace and security" of Europe, the second basket sets forth detailed guidelines and concrete recommendations for commercial, industrial, trade, scientific, technological, and environmental cooperation. Basket II describes in rich detail the kinds of economic cooperation advocated among the states. Recognizing "the growing role of international trade as one of the most important factors in economic growth and social progress," the states are encouraged to facilitate business contacts, improve the quality and increase the supply of econcmic and commercial information, and devote more attention to the knowledge 
THE HELSINKI PROCESS

and techniques required for effective marketing. Projects of common interest cited within a new framework of industrial cooperation are these:

- Exchanres of electrical energy within Europe with a view to utilizing the capacity of the electrical power stations as rationally as possible.

- Cooperation in research for new sources of energy and, in particular, in the field of nuclear energy.

- Development of road networks and cooperation aimed at establishing a coherent navigable network in Europe.

- Cooperation in research and the perfecting of equipment for multimodal transport operations and for the handling of containers.

The harmonization of standards and arbitration under "a mutually acceptable set of arbitration rules" are stated as sccond basket goals as well. A lengthy section on science and technology sets forth specific possibilities for improving cooperation among the states in agriculture, energy, new technologies, transport technology, physics, chemistry, meteorology and hydrology, oceanography, seismological research, glaciology, computer, communication and information technologies, space research, medicine and public health, and environmental research.

Similarly, the states are to make use of every suitable opportunity to cooperate in achieving such environmental goals as control of air pollution, water pollution control and fresh water utilization, protection of the marine environment, land utilization and soils, nature conservation and nature reserves, improvement of environmental conditions in areas of human settlement, and fundamental research, monitoring, forecast- 
ing and assessment of environmental changes. The development of transport, promotion of tourism, and economic and social aspects of migrant labor are other areas recommended for cooperation.

Cooperation in the four areas described in the third basket-human contacts, information, culture, and education-would contribute to the "strengthening of peace and understanding among peoples." All of these ambitious objectives are to be pursued "irrespective" of the "political, economic, and social systems" of the 35 participating states. In regard to human contacts, the states "make it their aim to facilitate freer movement and contacts, individually and collectively, whether privately or officially, among persons, institutions and organizations," including "contacts and regular meetings on the basis of family ties, reunification of families, marriage between citizens of different states, travel for personal or professional reasons, improvement of conditions for tourism, meetings among young people and sport."

To facilitate the freer and wider dissemination of information of all kinds, cooperation should include improvement in the circulation of, access to, and exchange of information, cooperation among radio, television, and press organizations, and improvement of working conditions for journalists.

Objectives for cooperation and exchanges in the field of culture are the following:

- Develop the mutual exchange of information with a view to a better knowledge of respective cultural achievements.

- Improve the facilities for the exchange of and for the dissemination of cultural property. 


\section{THE HELSINKI PROCESS}

- Promote access by all to respective cultural achievements.

- Develop contacts and cooperation among persons active in the field of culture.

- Seek new fields and forms of cultural cooperation.

Cooperation in the field of education would be fostered by expanding institutional links in education and science; improving access for students, teachers, and scholars to each other's educational, cultural, and scientific institutions; increasing the dissemination of scientific information and documents; encouraging the study of foreign languages and civilizations; and promoting the exchange of experience in teaching methods.

The prospect that such ambitious objectives can be pursued successfully over time is enhanced by the genius of the Final Act, which recognizes that true security depends upon balanced progress in security, human rights, and economic cooperation. It expresses not merely goals and principles to achieve this balance, but a program of practical steps for turning hopes into reality. It establishes a new standard toward which the states should strive and against which to measure their behavior. A long time may pass before all nations meet that standard, but the effort, in and of itself, is perceptively leading to more secure peace, greater individual freedom, and increased commerce, as affirmed at President Ronald Reagan's meeting with General Secretary Mikhail Gorbachev in Moscow in May 1988.

The Act's promise for inducing positive change in European security and cooperation stems also from 
the idea of equality expressed in Principle IX, "Cooperation among States." Acceptance of the principle of sovereign equality advanced by the Romanian and Finnish delegations at the Conference altered the pattern of East-West dialogue. Up to the time of the Conference, East-West negotiations had been carried out largely between the Warsaw Pact and NATO. The delegates agreed the Helsinki Process would take place outside these alliances. In theory at least, the smallest state would have as much to say in the outcome of negotiations as the largest, a neutral country as much as an aligned one.

The equality principle led to two important procedural rules for the Conference and the Helsinki Process: consensus voting and rotating chairmanships.21 The consensus rule meant that the big powers were not subjected to majority decisions with which they disagreed and smaller countries would participate more fully in the proceedings for they knew their consent would be necessary in final decisions. The delegates recognized that a decision reached by consensus has more moral force than one taken by majority vote. Because the Final Act was established by consensus, the participating states which signed it are bound by a mutual obligation, if not legal, a moral and political one, to fulfill all its provisions.

As important as the consensus rule has been as a cohesive force in the Helsinki Process, it has its drawbacks as well. The rule restricts decisions to the lowest common denominator of acceptance and gives decisive power to smaller states to influence the outcome of negotiations. Such power was used by Malta, for example, to insist on including in the Final Act 
THE HELSINKI PROCESS

a declaration on Mediterranean security and cooperation. The declaration noted that Europe's security is closely linked with that of the Mediterranean region, and declared that the Helsinki states should promote the "development of good neighborly relations" with nonparticipating Mediterranean states through economic, cultural, and scientific exchanges. These provisions would prove troublesome later at the Madrid review meeting.

The most important procedural rule, after the consensus rule, is the principle of rotating chairmanships in the plenary assemblies and working groups. This arrangement gives every state an equal part in chairing all the sessions. The same principle ensures all working groups are "open-ended" with free access for every state. The Helsinki Process thus excludes formal committees whose membership is confined to selected states. 22

The resolve of the Helsinki delegates "to continue the multilateral process initiated by the Conference" was a momentous decision, perhaps the most significant one of all at the Conference. The delegates realized that the Conference was a constructive part of the process of improving security and developing cooperation in Europe, which necessarily would be a long-term one. Therefore, with foresight, they included in the Final Act appropriate provisions for "Followup to the Conference." These provisions call for meetings among representatives for " $a$ thorough exchange of views both on the implementation of the provisions of the Final Act and of tasks defined by the Conference." 
The Final Act specified "the first of these meetings will be held at Belgrade in 1977" and further "this meeting will define the appropriate modalities for the holding of other meetings which could include further similar meetings and the possibility of a new Conference."

In looking back over the two years during which the Final Act was sealed, it could be said the diplomacy of Helsinki was the diplomacy of small steps. US career Foreign Service officer and Helsinki negotiator John Maresca believes it was only because the Soviets were worn down by an array of first, second, and third secretaries arguing about nuanced shades of adjectives, that they were willing gradually to make concessions on human rights and other sensitive issues. The relatively low-level Western negotiators made agreement on such sensitive subjects as human rights possible, because apparently the Soviets had concluded the results of negotiations conducted at such a low level of political interest would be quickly forgotten in Western capitals. 23

Contrary to this faulty Soviet assessment, political attention to the Helsinki accords increased in the West after the Conference, particularly in the United States. Because Soviet negotiators find it extremely difficult to make concessions under public pressure, the rise of high-level US political interest in the human rights aspects of the CSCE vith the change in US administrations after Helsinki caused Soviet willingness to participate in useful negotiations to decline proportionately. This trait would be amply demonstrated at the first Helsinki review meeting to follow in two years at Belgrade. 


\section{Two \\ Test of Wills at Belgrade}

WHEN US AMBASSADOR Arthur Goldberg, Soviet Ambassador Yuli Vorontsov, and representatives of 33 other states gathered to evaluate the performance of the Helsinki Final Act, the main concern in the minds of the Western representatives was progress in promised "human rights and freedoms."

The first Helsinki followup meeting began in the Yugoslav capital's new glass and steel Sava Center on October 4, 1977, following a two-month preparatory meeting there that summer. By that autumn, President Jimmy Carter had accorded human rights a priority higher than that of detente in US foreign policy. This precedence prompted a strong Western position on human rights at Belgrade, based on an interpretation of co-equal principles of the Final Act-"Non-intervention in Internal Affairs" and "Respect for Human Rights and Fundamental Freedoms"-that caused sharp, apparently irreconcilable conflict.24

The West, with the United States taking the lead, wanted to assail the East's abridgement of human rights; the Soviets of course did not wish to assume a defensive position. As a consequence the two nations clashed for five months at Belgrade in a monumental test of wills over this issue. Ambassador Goldberg hammered away righteously at the plight of Soviet dissidents. Soviet Ambassador Vorontsov sulked over these attacks, charging the United States with inter- 
THE HELSINKI PROCESS

ference in Soviet internal affairs and warning that the steady drumbeat on human rights could break up the meeting. 25 Diplomats from other countries, East and West alike, worried that such sharp confrontation between the superpowers would inevitably and irreparably harm the Helsınki Process.

The confrontation was predictable. The crackdown on members of the Helsinki monitoring groups in the Soviet Union and signers of the Charter 77 document in Czechoslovakia between the Helsinki and Belgrade meetings was swift and sometimes brutal. Such repression not only openly contradicted the Soviet pledges at Helsinki but also directly challenged the young US administration's commitment to human rights as the centerpiece of America's changing foreign policy. At Belgrade, Ambassador Arthur Goldberg fought hard to maintain international credibility for President Carter's commitment to this change, but his arguments constantly encountered skepticism among many delegates who saw the US position as idealistic but naive. 26

Although in his closing remarks Ambassador Goldberg called the Belgrade meeting a success, 27 the much-respected head of the Swiss delegation, Rudolf Bindschedler, gave it 1 percent success, 99 percent failure. 28 Another neutral diplomat called its thin concluding document, even though it preserved the Helsinki Process for another and brighter day, a "small harvest." 29 If these latter judgments were too harsh, they nevertheless reflected the deep disappointments and frustrations of the European delegates, who held much greater expectations for the Helsinki Process than the United States. In their view, they had far more 
to lose, so they resented what seemed like an ingenuous, perhaps even selfish US position.

Although not fully appreciated by many delegates at the time, the high standard of accountability set by the United States for implementing the Final Act in the field of human rights has since served the Helsinki Process well. Ambassador Goldberg's practice of naming persecuted human rights activists and countries responsible for their repression, although extremely controversial at the time, became generally accepted among Western delegations at Madrid in 1980-1983 and commonplace at Vienna in 19861989.30

\section{Spotlight on Human Rights}

The seeds of dissent at Belgrade were sown long before that meeting began. For reasons unforeseen by either side at the Helsinki summit, human rights emerged from its historical pattern of interest and neglect to overshadow other concerns of the Final Act between the Helsinki Conference in 1975 and the Belgrade meeting in 1977. Three events during that period made all the difference in changing national attitudes toward the Helsinki Process, particularly in the United States: the establishment of the US Helsinki Commission, the police crackdown on the Helsinki monitoring groups formed in the Soviet Union and elsewhere in Eastern Europe, and the election of a US President who placed the cause of human rights at the center of his foreign policy. 
THE HELSINKI PROCESS

\section{US Helsinki Commission}

Almost immediately after the Helsinki summit, the US Congress recognized the enormous political significance of the Helsinki accords. A Congressional delegation, while visiting Moscow less than a month after the Conference ended, was besieged by Soviet dissenters and Jewish activists urging action by the Congress to encourage liberal implementation of the Final Act within the Eastern bloc, not only in words but in reality.

The optimistic interpretation of the Helsinki accords by Soviet dissidents the delegation spoke with in Moscow and ethnic and religious constituencies at home was new to US politicians, many of whom had tended to dismiss the accords as a marginal bargain in the overall scheme of detente. 31

In response to steady pressure and appeals from dissidents in the East, especially in the Soviet Union, Poland, Czechoslovakia and East Germany, and ethnic and religious voters at home, the Congress created the Commission on Security and Cooperation in Europe over the objections of the Ford White House in June 1976, less than one year after the summit conference. The Helsinki Commission, as it is commonly known, is composed of 21 legislative and executive branch officials charged with monitoring and encouraging compliance with the Final Act. The Commission's broad mandate is to "monitor the acts of the signatories which reflect compliance with or violation of the articles of the Final Act . . . with particular regard to the provisions relating to human rights and cooperation in humanitarian fields." 
Equally as important in the long run, the Commission is further authorized and directed to "monitor and encourage the development of programs and activities of the US Government and private organizations ... to expand East-West economic cooperation and a greater interchange of people and ideas between East and West." Carrying out its mandate, the Commission actively documents violations of the Final Act, promotes public awareness of implementation of its provisions, and helps formulate and execute US Government policy on these issues. ${ }^{32}$

Regarding the Helsinki Commission an encroachment on the prerogatives of the executive branch to conduct foreign affairs, Secretary of State Kissinger and other senior administration officials reacted negatively to the Congressional initiative to establish it. They foresaw the possibility that executive branch representatives-asked to vote publicly on sensitive foreign policy questions-might be outvoted by Congressional members, which could be embarrassing. When the legislation that set up the Commission was passed, President Ford took the unusual step of signing it in private, not inviting the press to watch and not making any public statement as the bill became law. The administration's cooperation with the Commission was thus unfortunately strained for the remainder of the term. ${ }^{33}$ Incoming Secretary of State Cyrus Vance soon made amends, however. In the spring of 1977 , he praised the Commission for its "helpful and constructive role" and assured Commission Chairman Dante Fascell (D, Florida) that full cooperation between the State Department and the Commission had been achieved. ${ }^{34}$ This readied the Commission for its 


\section{THE HELSINKI PROCESS}

strong, steadfast contributions to the Helsinki Process, particularly in the field of human rights.

\section{The Helsinki Monitoring Groups}

The second significant post-summit development was the rise of the Helsinki monitoring movement in East Europe. Mass circulation of the text of the Final Act in the Eastern media familiarized millions of people with its important precepts on human rights and fundamental freedoms recently endorsed by their governments. The unexpected news of such welcome provisions ignited an extraordinary response. Within a week of the creation of the Helsinki Commission, Soviet activist Yuri Orlov and 10 others announced the formation in Moscow of the Soviet Helsinki Watch ("The Public Group to Promote Observance of the Helsinki Agreements in the U.S.S.R."). Companion bodies in Ukraine, Lithuania, Georgia, and Armenia arose as well. These small but unique and unprecedented citizens' groups were comprised of individuals stimulated by Principle VII of the Final Act to form groups to "know and act upon" their rights. Seeking to encourage Soviet authorities to bring their human rights practice more into line with pledges made at Helsinki, these groups published numerous reports documenting violations of human rights and freedoms.

Similar monitoring groups of ordinary citizens originated in other East European countries. In January 1977, in Czechoslovakia, approximately 300 citizens formed an organization known as "Charter 77," which published trenchant reports on the status of their government's implementation of its own laws and international obligations, including the Helsinki Final Act. ${ }^{35}$ 
In 978 , an affiliated group, the Committee for the Defence of the Unjustly Persecuted began to document and report violations of basic human freedoms. In 1977, in Poland, the Committee on Worker's SelfDefense broadened its activities to include human and civil rights. Two years later this Committee organized Poland's first Helsinki monitoring group, which, like its counterparts in other East European countries issued a series of critical reports documenting failures of observance of human and civil rights. This very Committee subsequently helped to form the free trade union, Solidarity, in August 1980.

The unexpected mushrooming activity of the Helsinki monitoring groups in East Europe quickly brought repressive crackdowns. In early 1977 , Soviet authorities arrested the chairman of the Soviet Helsinki monitoring group, Yuri Orlov, on charges of high treason (Article 64 of the Soviet Criminal Code) along with four other prominent human rights activists, who had been monitoring Soviet implementation of the accords. By this time, his group had published 19 reports on such matters as religious freedom, family reunification, and the rights of national minorities. 36

The Czechoslovak Government responded with a massive propaganda campaign denouncing Charter 77 and its supporters. Authorities arrested Charter 77 spokesmen Vaclav Havel, Jiri Lederer, and Frantisek Pavlicek and detained and questioned others. Many signers were dismissed from their jobs or otherwise harassed.37 Widespread Western publicity surrounding such repressive steps in the East added impetus to the Carter Administration's propensity for human rights. 
THE HELSINKI PROCESS

\section{A Presidential Initiative}

The third important development affecting the Belgrade meeting was the election of President Carter, who believed so strongly in fundamental human rights that he made the performance of other governments in providing basic freedoms to their people a significant element in US relationships with them. Secretary of State Cyrus Vance summed up the Administration's resolve to make the advancement of human rights a central part of American foreign policy in a major speech at the University of Georgia in April 1977.38 The Presidential initiative of upgrading human rights in US foreign policy catapulted the United States from a lowprofile participant at Helsinki to a high-profile, hardline participant at Belgrade.

\section{Escaping Forward}

The prospect of the thorough review of implementation of the Final Act at Belgrade prompted some steps toward liberalization in the East that might not otherwise have been taken. In the Soviet Union itself, the emigration of Jews increased dramatically just before the Belgrade meeting-rising from a 1976 average of about 1,150 to approximately 1,800 monthly. Even stolid Bulgarian officials softened their policies regarding long-standing family reunification cases. In June 1977 , apparently timed for the Belgrade meeting, the Czechoslovak Government proclaimed an amnesty for those people who had left the country after 1968, resolved 13 of 20 out tanding US family reunification cases involving children, and permitted public sale of limited quantities of certain previously unavailable Western newspapers and journals. The number of small, positive 
steps taken before the meeting began suggests an urgent effort by Eastern governments to improve their Final Act performance before it came under public scrutiny irom the West. ${ }^{39}$ About that time, the Helsinki Commission's first report to the Congress found "the record of the first two years has been more productive than the Commission expected, though far short of the high promises which the language of the Final Act holds forth." 40 Recognizing the gap between high promises and meager compliance, the Soviet Union and its allies came to the Belgrade preparatory meeting knowing their record on human rights would be broadly criticized, and they were correct.

On June 15,1977 , the preparatory meeting opened with considerable fanfare in the presence of 350 journalists. It did not take long, however, before delegates realized the kind of main meeting the West wanted was not the kind the Soviets had in mind. The West wanted a thorough review of the Act's implementation since Helsinki; the East wanted no criticism of its shortcomings, especially in the field of human rights. Instead the East favored a series of sessions devoted to future promises rather than past commitments. Senator Claiborne Pell (D, Rhode Island), cochairman of the Helsinki Commission, dubbed this Eastem tactic of blurring the distinction between reviewing implementation and advancing new proposals an attempt to "escape forward." 41

Led by Ambassador Arthur Sherer, a career Foreign Service officer and one of the architects of the Final Act, the small State Department-Helsinki Commission team in Belgrade viewed the task of the preparatory meeting as a limited, largely technical one: 


\section{THE HELSINKI PROCESS}

to set the dates, agenda, and procedures for the main meeting. The Western position had been prepared by this time in the NATO caucus, following the successful practice of consultation among the allies well honed in negotiating the Final Act. The neutral and nonaligned nations were helpful at the preparatory meeting in working out compromise positions, as they had been since the beginning of the Helsinki negotiations. Although the delegates found it necessary to continue beyond their allotted six weeks, they finished with a high degree of optimism about the main meeting in just over seven weeks, when the Yugoslav Government insisted the staff had to go on holiday.

\section{The Yellow Book}

The real importance of the preparatory round was the negotiation of vhat delegates referred to as the "Yellow Book." This was the book of decisions of the preparatory meeting. (The full title continues for 45 words in English.) After weeks of tough and sometimes acrimonious bargaining, the Yellow Book gave the West essentially what it wanted, namely, a mandate for reviewing implementation, considering new proposals for deepening cooperation, and scheduling another followup meeting. In no event would the Belgrade meeting adjourn until adoption, by consensus, of a concluding document and the setting of the time and place for another similar meeting. The decisions taken at the preparatory meeting thus established procedures of crucial significance for continuing the Helsinki Process. 42 


\section{A Surprise Appointment}

When the preparatory meeting ended, a British journalist reported a "rather low and uncertain profile of the new American Administration, which gave the impression of not having fully decided how to handle the conference." 43 Ambassador Albert Sherer fully expected that Deputy Secretary of State Warren Christopher would head the US delegation at Belgrade, deliver a keynote speech, then return to Washington leaving the actual negotiating to his team of experts.44 The Ambassador's expectations proved inaccurate when, in a surprise last-minute move, President Carter appointed Arthur Goldberg, a former Associate Justice of the Supreme Court, US Representative to the United Nations, and skilled negotiator, to head the US delegation. Ambassador Goldberg's intellect, integrity, and extraordinary experience made him the Carter administration's perfect choice to advance the cause of human rights at the conference.

When the delegation eventually lined up in Belgrade, the American presence was overwhelming, according to one delegation member. "Not only was the Congressional commission playing a much more active role, but there was a mind-boggling array of public members appointed by the White House, the Secretary of State and by Justice Goldberg himself." Over 140 Americans were authorized official badges, compared with 35 in the Soviet delegation, 12 each in the British and French, and five in the Canadian. They included representatives of the American labor movement, B'nai B'rith, a Roman Catholic monsignor, an Eskimo, a black woman lawyer, a Polish-American political science professor, a college president, busi- 


\section{THE HELSINKI PROCESS}

nessmen, professional civil rights champions, and Mesdames Goldberg and Sherer. The nature of the US delegation is particularly noteworthy because it marked the beginning of an expanded and productive role for US public diplomacy in the Helsinki Process. Frequent press conferences of the US delegation, some by public members on their own, caused the Soviet press to charge the Americans were "playing the meeting for parochial political gain." 45

\section{A Question of Style}

The Belgrade meeting began October 4, 1977, in open plenary session, for the formal welcome by Yugoslav Foreign Minister Milos Minic and opening statements by 35 heads of delegation. With international press interest still high, Ambassador Goldberg went right to the heart of the dialogue on human rights the United States sought from the meeting: "Human rights represents the widest gap between the ideals and practices of East and West. It is a sensitive subject ... but one which must be discussed." 46 The constructive discussion the United States sought never ensued. In the resulting vacuum, the two sides talked at each other month after month about past violations, and about new proposals which neither side could possibly accept under such strained circumstances.

First the French and then the Canadians spoke out about human rights violations in East Europe. The United States then took the lead for the West in criticizing the Soviet Union and Czechoslovakia, among others, for improperly harassing, arresting, imprisoning, interning in forced labor camps, confining in mental institutions, and exiling their own citizens, whose only 
crime was to monitor compliance with the Final Act and peacefully to protest violations. If other countries shared dissatisfaction with the human rights records of the Soviet Union and others, they refrained from denouncing them for fear of offending Eastern sensitivities. But other Western countries did condemn the failure and refusal of the Soviet Union and other East European countries to permit the reunion of families and emigration of ethnic and religious minorities. 47

The Soviet response to US criticism of their human rights record ran a gamut. Soviet Ambassador Vorontsov threatened at one point to break up the meeting, linking the language of discussion to that of the Cold War. The Soviet media labeled American speeches on human rights "aggressive" and "fanatical," frequently singling out Justice Goldberg for personal attack.48 When such superficial tactics failed, the East turned to a more diplomatic approach in rebutting Western criticism of human rights violations, arguing that such criticism constituted interference in their internal affairs, contrary to Principle VI of the Final Act. The Soviets persisted in these arguments even though this Principle was "meant above all to forestall military or other coercion, not to serve as a gag rule against comment on any domestic matters." 49

Under continuing pressure on human rights, the Soviets sometimes augumented their noninterference argument with a barrage of criticism on the deplorable state of social and economic rights in the United States, particularly the discrimination against blacks, unemployment, and repression of women. Such attacks had considerable significance for the Helsinki Process, because for the first time, they legitimized the criticism 


\section{THE HELSINKI PROCESS}

of the human rights performance of other states and demonstrated that states could require an accounting from each other on this issue. 50

The prolonged and divisive US-Soviet standoff on human rights strained Western unity at Belgrade. West European diplomats, whose governments had benefitted from the Helsinki Process through the repatriation of ethnic minorities from the East and in other ways felt betrayed. Representatives from neutral and nonaligned states felt isolated from their previous role as intermediaries. Strains developed even within the US delegation, as well. Veteran Helsinki negotiator Albert Sherer believed all along the United States could adopt a stance true to American human rights principles without jeopardizing realistic and practical results and without alienating our allies and other countries of Western Europe. The difference, to him, was "a question of style." 51 But by then, with the superpowers at loggerheads over human rights, there was little hope for the acceptance of new proposals.

\section{Balanced Progress at Stake}

Four new proposals were advanced under the "Confidence Building Measures and Certain Aspects of Security and Disarmament" provisions of the Final Act: one each from NATO, the neutral and nonaligned nations, Romania, and the Soviet Union.52 The earlier review of compliance in this area had shown that each state had met its obligations under the Final Act, to notify other states of its military maneuvers exceeding 25,000 troops at least 21 days in advance.

The NATO proposal, strongly supported by the United States, would strengthen provisions of the Final 
Act by prescribing additional information to be included in announcing maneuvers, adding an obligation to announce smaller scale maneuvers (those involving 10-25,000 troops), establishing a detailed code for the treatment of observers, and setting a clearly defined requirement for notification of major ground force movements.

The neutral and nonaligned proposal was conceptually similar. While evading discussion of specific proposals, the Soviet Union and its allies challenged them on general grounds. They made clear their preference for disarmament proposals over confidencebuilding measures and insisted that progress in such measures would only go hand-in-hand with progress in military detente, the theme of the Soviet proposal entitled "Programme of Action with a View to the Consolidation of Military Detente in Europe."

Based on a passage from a speech delivered by President Brezhnev on the eve of the Belgrade meeting, the Soviet proposal sought four objectives: a treaty on the non-first-use of nuclear weapons, a treaty prohibiting the employment of political and military alliances in Europe (aimed at preventing Spain from joining NATO), limits on the size of maneuvers to "say, $50,000-60,000$ men," and in a restated version, agreement on mutual renunciation of the production of the neutron bomb.

One element of the Soviet proposal called for post-Belgrade "special joint consultations" among the 35 members at a political level higher than Belgrade, to consider "all constructive proposals" concerning military security. Western diplomats soon tagged this as nothing more than a propaganda platform, leaving 


\section{THE HELSINKI PROCESS}

it with no support outside the Warsaw Pact delegations. Yugoslavia, Romania, and Sweden made a last effort to sustain momentum in the military security area by proposing a post-Belgrade working group to consider confidence-building measures. Their initiative failed, because the Soviets showed little interest in a meeting restricted to such measures. The United States and NATO allies argued that to provide for a military security working group without equivalent progress in human rights would seriously unbalance the Helsinki Process.

After the meeting, Soviet representative to the UN Commission on Human Rights Vladimir Lomeiko condemned the United States for the failure at Belgrade "to record any statement on military detente, in spite of the great interest the neutral and nonaligned nations had shown in this matter." Although the West had united in rejecting the Soviet proposal, Lomeiko asserted it was the US delegation that "prevented any decision being taken on military detente." Not all was lost, however, because the exchange of views at Belgrade encouraged more constructive discussions at Madrid, which led in tum to major progress in confidencebuilding measures at Stockholm in 1986.53

Altogether the Belgrade meeting considered more than 90 proposals from East and West alike for deepening cooperation in Europe across the enormous range of Helsinki interests: from facilitating family reunifications and binational marriages to an international code for the treatment of journalists; from aiding direct contacts between scientists to all-European, high-level meetings on environment, energy, and transportation; from respecting human rights and fundamental free- 
doms to respecting the right to work and the rights of women; and from education for peace to improving the accessibility of economic information for businessmen. All the proposals were considered, but none was adopted.

\section{More Than A Goalless Draw}

During the Christmas recess, while Ambassador Goldberg met with representatives of emigre groups in the United States and reiterated publicly his intention to press until the bitter end on humanitarian issues, the Soviets in Moscow decided to end the meeting. When the delegates reconvened in mid-January, the Soviets tabled a brief, three-page draft concluding document containing mainly their favored military security and economic cooperation proposals. Almost all delegations, except the Soviet Union's closest allies, immediately criticized the lack of balance and substance in the draft. The only positive aspect of the document was its short section scheduling the next followup meeting for Madrid in 1980. Humanitarian issues were confined to a single reference to the readiness of the participating states "to continue the expansion of cooperation in humanitarian fields, as provided for in the Final Act: human contacts, information, culture and education."

Seeking a realistic compromise, the neutral and nonaligned states circulated a draft two weeks later which the Eastern countries summarily rejected for its objectionable reference to human rights. A compromise French effort failed. A balanced, 18-page NATO text also failed when the Soviets made it bluntly clear 


\section{THE HELSINKI PROCESS}

they would never agree to any mention of human rights in the concluding document.

Recognizing that an unbalanced document would set a dangerous precedent for the Helsinki Process, the United States and its NATO allies then prepared a brief statement which formed the basis of the concluding document accepted by consensus March 9, 1978.54 Using a sports analogy, one diplomat called Belgrade a "goalless draw." ss In retrospect, the West ended up ahead. The meeting established favorable precedents for the future, and although threatened at times by US tactics, Western unity prevailed in preserving the Helsinki Process without compromising its principles.

In essence, the concluding document stated the signatory states had met, conducted the exchange of views on implementation mandated by the Final Act, and differed on the degree of implementation achieved thus far and on new proposals submitted to the meeting. It reaffirmed the political importance of the Helsinki Process and the resolve of the participating states "to implement fully, unilaterally, bilaterally, and multilaterally, all of the provisions of the Final Act." 56 Furthermore, it successfully countered one of the main Soviet themes at Belgrade-that progress in implementing the Final Act is contingent upon the favorable development of detente. The concluding document made clear that implementation of the Final Act is essential for the development of detente. Most important, the document sustained the Helsinki Process by scheduling the second followup meeting to commence at Madrid November 11, 1980, with a preparatory meeting to be held there beginning September 9. It 
also assured a thorough and detailed review of implementation at Madrid, as at Belgrade. Finally, it provided for several meetings of experts: in Switzerland in 1978, to consider a generally acceptable method for peaceful settlement of disputes; in Germany in 1978, to prepare a scientific forum; and in Malta in 1979, to discuss economic, scientific, and cultural cooperation among Mediterranean states. When the meeting formally ended the following day, Western delegates returned home disappointed, but at the same time relieved to have a concluding document and hopeful the worst was over. With the next review two years ahead, no one could yet foresee the crisis to come at Madrid. 


\section{Three}

\section{Crisis at Madrid}

BETWEEN THE BELGRADE and Madrid meetings, the Helsinki accords inspired few achievements. Among them was the meeting of experts on the "Peaceful Settlement of Disputes" at Montreaux in December 1978, which agreed on a common approach toward settling disputes, even if delegates failed to agree on specific methods. Experts meeting on "Mediterranean Cooperation" in Valletta in February and March 1979 produced worthwhile recommendations for cooperation among the Mediterranean states, including eight nonparticipating states (Morocco, Tunisia, Algeria, Libya, Egypt, Israel, Lebanon, and Syria), in the fields of economics, science, and culture. The "Scientific Forum" at Hamburg in February and March 1980 carried out its mandate by discussing problems of common interest in science and promoting wider contact and exchange among scientists and their institutions, although the meeting might have accomplished much more had it been free from the stain of invasion in Afghanistan and maltreatment of scientists. 57

\section{Few Successes, Many Failures}

In the United States, President Carter initiated steps to fulfill even more effectively the US side of the Helsinki bargain. 58 In the area of civil and political rights, such steps involved reviewing specific cases of alleged "political prisoners" and speeding legisla- 
THE HELSINKI PROCESS

tion for the potential redress of grievances by people in prisons and psychiatric hospitals.

With respect to economic and social rights, US agencies initiated special programs of improved services in education, employment, and housing. The Bureau of Indian Affairs established a new relationship with tribal governments giving Indians a more direct role in Federal policy and programs affecting their interests. The President submitted to the Senate for advice and consent the UN Covenants on Human Rights, including the UN Covenant on Civil and Political Rights and the UN Covenant on Economic, Social and Cultural Rights. The Eastern states, all parties to these Covenants, had strongly criticized the United States at Belgrade for not having ratified these documents.

By signing the Refuge Act of 1980, the President established a systematic and flexible procedure for the admission and resettlement of refugees. The United States took a major step forward in advancing economic cooperation within Basket II by adopting the Trade Agreement Act of 1979, which would move US policy toward greater participation in a more liberal world trading system.

The Carter administration's concentrated effort to accelerate US compliance with the Final Act between the Belgrade and Madrid meetings was not equalled in the Soviet Union, where the human rights record continued to worsen. As the Madrid meeting approached, the relentless government campaign of repression against human rights activists and their organizations remained in force, with more than 150 arrests of Soviet citizens for their human rights beliefs in 
six months. The slowdown of this campaign during the Moscow Olympics proved temporary, and many dissidents arrested earlier were tried and given heavy sentences. 59

Through imprisonment, harassment, and exile, Soviet authorities decimated the groups founded in the USSR to monitor Soviet compliance with the Helsinki Final Act. Rather than allow private citizens to take such action, the government chose to suppress their activities. Their advocacy of human rights was denounced and prosecuted by authorities as anti-Soviet slander and subversion. Some were subjected to psychiatric imprisonment and abuse on grounds their beliefs were evidence of insanity. Many others were sentenced to long prison terms. The co-founder of Moscow's Helsinki monitoring group, Yuri Orlov, while serving a seven-year sentence under harsh conditions in labor camp Perm 2, was sentenced in September 1980 to six months of solitary confinement for protesting inte.ference with his correspondence and demanding an improvement in camp conditions. 60

The Ukrainian Helsinki monitoring group was hit particularly hard, with most members imprisoned or exiled. Soviet authorities also systematically hounded the groups founded in Armenia, Georgia, and Lithuania. The distinguished physicist and Nobel Peace Prize winner Andrei Sakharov, one of the most forceful and eloquent spokesmen for human rights in the Soviet Union, remained cut off from most outside contacts in exile in the closed city of Gorky, where Soviet security agents took him January 22, 1980. Religious groups not registered with the Soviet government were severely harassed, and many of their leaders were im- 


\section{THE HELSINKI PROCESS}

prisoned, because mere membership in such groups was a criminal offense. Religious activists faced a wave of arrests and trials before the Madrid meeting and disturbing signs of anti-Semitism appeared in the Soviet press.61

Contrary to the Final Act's goal of freer dissemination of information, several Eastern countries continued to jam Western radio broadcasts. The Soviet Union took a major step backward on August 20, 1980, when it resumed jamming Voice of America, BBC, and the Federal Republic of Germany's Deutsche Welle broadcasts. All VOA services directed at the Soviet Union, with the exception of the English service, were being jammed on some or all frequencies. 62

East-West relations before the Madrid meeting were sharply deteriorating for another reason than repressive Soviet human rights abuses. The brutal invasion of Afghanistan in December 1979 and its continuing occupation by Soviet troops not only contradicted the spirit of the Final Act, but violated its guiding principles pertaining to the sovereign equality of states, the threat or use of force, the inviolability of frontiers, territorial integrity, internal affairs, and the equal rights and self-determination of peoples. The Final Act requires its signatories to refrain from the threat or use of force "in their international relations in general," not just in dealing with other states which signed the Helsinki accords. Such flagrant behavior toward human rights and Afghanistan gave the Soviet Union a dismal Helsinki record for the West to review at Madrid. 


\section{The Helsinki Lobby}

To deal with the Soviet's Helsinki record firmly, but less confrontationly than at Belgrade, President Carter appointed in the summer of 1980 to head the US delegation at Madrid his close friend from Georgia and former Attorney General, Griffen Bell, and as his co-chairman, Max Kampelman, a prominent Washington lawyer and well-known Democrat active in Jewish affairs. To augment the US delegation of diplomats and members of Congress, the President added 30 public members, even more than at Belgrade, from many ethnic, religious, and human rights groups known as the "Helsinki Lobby." 63 These appointments raised public diplomacy to a new height in a Presidential election campaign. The presence on the US delegation of so many influential citizens from a wide crosssection of American society demonstrated both the widespread American concern over human rights violations of the Final Act and the influence of the Helsinki Lobby in an election year.

To mark the fifth anniversary of the signing of the Helsinki Final Act, in August 1980, leaders of the US delegation met with representatives from over 100 Helsinki Lobby organizations to discuss the upcoming Madrid meeting.64 For well over an hour, spokesmen from these nongovernmental organizations questioned, criticized, and sometimes lectured Chairman Bell and his colleagues about what Washington's policy toward the Madrid conference should be, dramatizing the cunsiderable influence this group had gained since the Final Act was signed.

As a unified movement, the Lobby brings the special interests of millions of US voters to the atten- 


\section{THE HELSINKI PROCESS}

tion of government officials responsible for CSCE affairs-interests which mostly involve promoting the rights of ethnic and religious minorities and facilitating East-West emigration. At this meeting, nongovernmental organizations not represented on the US delegation were promised opportunities to meet with delegation members in the Spanish capital to receive briefings on the progress of the conference and to exchange views with US officials.

In that same month, Moscow's Helsinki monitoring group advised against transferring the boycott of the Olympic Games that summer to the Madrid conference, as was being debated in the United States, and instead advocated American participation in the meeting as a useful means for drawing public attention to Eastern abuses of human rights. The group urged that Madrid confirm the link between human rights and détente and upgrade human rights in international law. 65

\section{A Difficult Meeting}

The Madrid followup meeting of the Conference on Security and Cooperation in Europe opened on November 11,1980 , as the Helsinki community had agreed more than two years earlier at Belgrade. Until the final hours of that day in Madrid's Palacio de Congresos, delegates doubted the meeting could begin as scheduled owing to Soviet disagreement over its agenda and procedures. The preparatory meeting to resolve these questions had convened at Madrid nine weeks earlier, but despite around-the-clock negotiations for six weeks longer than originally planned and artificially stopping the conference clock at two minutes 
to midnight November 10, to gain more time, November 11 arrived without agreement.66

The deadlocked negotiations on an agenda and procedures resulted largely from Soviet efforts to deny the West sufficient time to conduct a thorough and orderly review of implementation of the Final Act since the Belgrade meeting. Repeated Soviet refusal to agree to procedural arrangements based on the Belgrade model raised fears at that point that Moscow had decided to scuttle the Helsinki Process. 67

At the preparatory meeting, the Soviet Union, in conjunction with several other Warsaw Pact countries, gradually revealed its initial position on procedures for the main meeting. This position, which was not fully disclosed until a full month into the preparatory meeting, would have severely curtailed the review of implementation of the Final Act compared to the time allowed at Belgrade. The NATO countries argued that the Yellow Book should serve as the guide for Madrid, to preserve from the Belgrade precedent adequate time to examine the record of compliance with the Final Act and to consider new proposals. The Yellow Book would also establish the clear commitment to set the date and place of the next followup meeting. These elements were missing from the procedures suggested by the Warsaw Pact.68

Without a consensus late on November 11 , the Spanish Government decided to open the main meeting at 15 minutes before midnight without an agenda. In a slightly incredulous atmosphere with no one quite ready to believe it was really happening, Spanish Foreign Minister Jose Pedro Perez Llorca stepped onto the rostrum to deliver a two-minute speech formally 
THE HELSINKI PROCESS

opening the conference, greeting the delegates, forming a working group to resolve remaining problems, and adjourning the meeting until the next day. After a long coffee break in the early hours of November 12 , during which differences subsided, working group members evolved ad hoc procedures which would permit the remainder of the week to be devoted to opening speeches by heads of delegation, in an order chosen by lot.

The Spanish and Soviet delegations succeeded in breaking the deadlock during the coffee break. Those who were there say the delegates agreed the reputation of the entire Helsinki community would be damaged if their squabbling prevented the conference from beginning as scheduled. An important factor in their agreement was the presence in the opening plenary session of more than 20 public members of the US delegation. Drawn from many areas of ordinary American life, these delegates had openly expressed shock and dismay at the quarreling and difficulties encountered in reaching agreement on straightforward procedural details for the meeting. 69

The arrangements accepted for the opening week paralleled those of the Belgrade meeting, but procedures to govern events beyond the initial speeches were missing. To extend them, the Foreign Ministers of Yugoslavia, Austria, Sweden, and Cyprus introduced a proposal late on November 13, which they characterized as a last effort to overcome the procedural impasse. The Western countries accepted the proposal immediately, even though it meant giving up important procedural safeguards, and on the evening of November 14, the Soviet Union also gave its consent. The 
plenary session then quickly adopted the proposal as the format for the Madrid meeting. 70

The format specified an initial week of speeches by the 35 delegates in plenary sessions open to the public, followed by a second week of closed plenary debate. Beginning the third week, five working groups (formally designated subsidiary working bodies) would form to review compliance with the Final Act through the sixth week of the meeting. By accepting these procedures, the West made concessions to reduce the length of review and waive the automatic requirement for a further review meeting after Madrid.

\section{Reviewing the Record}

Despite the gloomy atmosphere and loss of safeguards, the first phase of the meeting, from November 11 to December 19 , produced a more thorough and candid review of implementation than was achieved at Belgrade. This result was due $i$, a number of factors: greater allied unity, the worsened Soviet record on human rights, the invasion of Afghanistan, and the willingness of a growing number of Helsinki states to criticize the Soviet Union directly. Soviet intransigence was an important catalyst in maintaining allied unity and in encouraging allied, neutral and nonaligned nations to take a forthright position against Soviet and East European violations of their solemn commitments under the Helsinki accords. In comparison to Belgrade, the Western states were more critical and specific during the Madrid review; the American delegation alone cited 60 individual cases of human rights violations in the USSR and Czechoslovakia. ${ }^{71}$ 
THE HELSINKI PROCESS

Allied and neutral support for the critical US stance was helped by the fact that Soviet Deputy Foreign Minister and delegation head Leonid Iiyichev and Yuri Dubinin, Soviet Ambassador to Spain and the number two man in their delegation at Madrid, reacted to criticism in a far more relaxed and resigned manner than had been the case at Belgrade, where even the slightest criticism had evoked an immediate, polemical and, for some, intimidating response. When specific cases were cited or their countries were directly attacked, however, the Soviets and East Europeans counterattacked with criticism of alleged US shortcomings. Their response almost always included a repeated argument condemning interference in their internal affairs. 72

\section{On Principles and Security}

The sessions reviewing Basket I Principles were notable for the breadth of Western criticism of the Soviet invasion of Afghanistan and Soviet human rights violations. On various aspects of human rights, Ireland, the United Kingdom, Belgium, the Vatican, France, and the United States criticized official attempts to control religious life; Belgium and the United States criticized state-sponsored anti-Semitism; and Canada, Belgium, the United Kingdom, France, the Federal Republic of Germany, Ireland, and the United States criticized the repressive campaign against Helsinki monitors in the USSR and Czechoslovakia.

The time-consuming speeches by Warsaw Pact delegates concerning their own "flawless" record of implementing each Principle were also notable. In a series of lengthy speeches, the Soviet Union generally 
took a "high tone" in discussing its own record of compliance with the Principles by pointing to the numerous bilateral treaties it had signed. When the Soviet representative claimed that all ten of the Final Act Principles had been incorporated into the 1977 Soviet Constitution, the British delegation effectively undercut this claim by pointing out that an essential part of Principle VII relating to human rights had been glaringly omitted. 73

In reacting to statements by other delegations, the Soviet Union adopted a relatively restrained tone. The Soviet representative characterized Western criticism as inadmissable interference in its internal affairs but, until late in the meeting, did not counterattack with criticism of Western shortcomings. It was only when the Belgian representative labeled the imprisonment of Helsinki monitors in the USSR and Czechoslovakia "revolting and abhorrent" and called for their release, that the Soviet representative responded by saying that such "misuse" of the Madrid meeting "could result in the destruction of the CSCE process."

The Soviet delegate also reacted vituperatively to a tough US Principle VII speech by Helsinki Commission Staff Director and Deputy Chairman of the US delegation R. Spencer Oliver, by charging the United States and Great Britian with using Principle VII for Cold War purposes in their struggle against socialism and by citing a litany of "massive human rights problems" in the United States which supposedly violate the Final Act: unemployment, racial discrimination, and police brutality, among others. 74

Deputy Chairman of the US delegation Warren Zimmermann delivered a strong US statement on Prin- 


\section{THE HELSINKI PROCESS}

ciple VIII, denouncing the illegal Soviet annexation of the three Baltic states. He told the assembly the United States does not recognize the forceful incorporation of Latvia, Lithuania, and Estonia by the Soviet Union and condemned the persecution of many Baltic citizens who signed an August 1979 petition asking the Soviet government to nullify the Molotov-Ribbentrop Pact by which those states were annexed. When the Soviet representative criticized the United States for focusing on "petty issues," Ambassador Zimmermann responded that this issue was far from petty, since the smallest of these three countries was larger than eight nations represented at the Madrid meeting. Characteristically, then, the Soviets returned to their earlier argument against interference in their internal affairs. 75

The review of compliance in the military security area of Basket I produced no surprises, as all East and West states had properly implemented the key confidence-building measures set forth in the Final Act.76 Nonetheless, the US and other NATO delegations, as well as most neutral and nonaligned countries, were concerned enough about the current tense atmosphere in Central Europe, resulting from the invasion of Afghanistan and unrest in Poland, to stress the military inadequacy of these security measures.

As Soviet and Warsaw Pact troop activity near Foland's borders began to intensify during the final weeks of the meeting's first phase, Western delegations began to speak, without mentioning Poland, of the need for mandatory, verifiable and more militarily significant confidence-building measures applicable to all of Europe, not just the zone within 250 kilometers 
of Soviet borders covered by the confidence-building provisions of the Final Act.

\section{On Trade and Science}

Compared with other reviews at Madrid, meetings on trade and other aspects of Basket II were least combative. 77 The Soviet Union tended to strike a positive note, stressing the growth of East-West trade and the number of bilateral agreements concluded with various countries. During some 20 working group sessions before the Christmas break, the West mildly faulted the Soviet Union and other countries of East Europe for their failure to provide adequate facilities for Western business representatives and timely economic and commercial information, and for their adherence to overly restrictive conditions for trade. Also, Western countries commented adversely about the so-called "counterpurchase" system employed by Soviet bloc countries, a barter-like arrangement which linked exports and imports, constituting a form of protectionism.

Generally, the Soviet Union and the East European delegates maintained a low profile, refraining from directly raising such sensitive issues with the United States as its refusal to grant most-favored-nation status to all Soviet bloc countries and the imposition of trade sanctions after Afghanistan. At one point, however, the Soviets interrupted the relative calm of the proceedings by denouncing the Carter administration's action to revoke a Dresser Industries license, which would have allowed the company to sell the Soviets technological and management know-how for a nearly completed oil drilling bit manufacturing plant. The Soviets reacted strongly a second time when the 


\section{THE HELSINKI PROCESS}

US delegate attributed the deterioration of US-Soviet scientific exchanges to aggression in Afghanistan and deprivation of Soviet scientists' human rights. An intemperate response accused the United States of unilaterally, "without provocation from the East," breaking off scientific collaboration and urged the United States to review its own implementation record before lodging complaints against others. Throughout, the Western representatives reminded the Soviets that they were responsible for creating the current international friction and that, until their actions restored some semblence of international stability and mutual confidence, the level of trade and scientific cooperation would be minimal.

In reviewing scientific exchanges and the human rights of individual scientists, the United States, United Kingdom, Canada, and Sweden presented the hardesthitting statements of all the countries on topics ranging from Soviet harassment and imprisonment of refusenik and dissident scientists to the misuse of psychiatry for political purposes. The arrest of Vladimir Brailovsky, the exile of Andrei Sakharov and the psychiatric detention of Juri Kukk were cited as examples of Soviet actions which had caused many Western scientists to cease cooperation with Soviet colleagues. 78

\section{On Human Contacts, Information, and Culture}

Basket III discussions were much franker and more specific than durin he Belgrade meeting. Virtually all Western countrass raised problems ranging from restrictions on family reunification to impediments to scientific exchange and obstacles to the free flow of information. The United States continued to mention 
specific victims of Eastern failure to implement the Final Act and was not alone in employing this tactic. Even states which did not cite individuals' names made forceful and comprehensive statements on various problems. The Eastern response varied, but was impressive for its lack of vehemence and avoidance of the nonintervention argument. The Soviet delegation, in particular, let pass in silence criticism which in Belgrade would have occasioned vociferous replies.

On human contacts, as during most phases of the review, the Soviet Union came in for the largest share of criticism. Western delegations questioned the drastic reduction in Soviet Jewish emigration in 1980 (see table on page 58), deplored the increase of Soviet anti-Semitism, and criticized bureaucratic and procedural obstacles to emigration, including harassment directed against unsuccessful applicants for emigration. The United States charged the Soviet Government with misusing the family reunification provisions of Basket III, to justify restricting rather than facilitating emigration and with curtailing the availability of Soviet and East European laws and regulations concerning emigration, thus adding further obstacles to freer movement. 79

The Soviet spokesman insisted that each govemment, under the Final Act, was entitled to determine its own laws, without outside intervention. The USSR, he argued, was dealing with such matters as family reunification in a humanitarian spirit and placed no obstacles to reunification or to marriage with foreigners, claiming 15,000 family reunifications and foreign marriages had taken place in recent years. 80

The implementation records of East Germany, Romania, and Czechoslovakia also earned criticism. While 
THE HELSINKI PROCESS

\section{Table 1. Jewish Emigration from the USSR}

\begin{tabular}{|c|c|c|}
\hline 970 & & 18 \\
\hline 1971 & ........... & 13,022 \\
\hline 72 & . & 68 \\
\hline 73 & $\ldots$ & \\
\hline 74 & 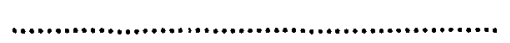 & 20 \\
\hline 75 & (2) & 13 \\
\hline 76 & 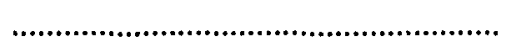 & 14 \\
\hline 77 & 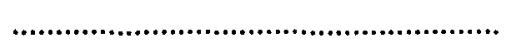 & 16 \\
\hline 78 & (1) & 28 \\
\hline 79 & 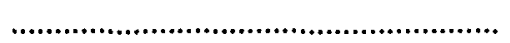 & 51,32 \\
\hline 1980 & . & 21,47 \\
\hline 1981 & . & 9,4 \\
\hline 1982 & 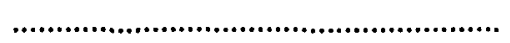 & 2,68 \\
\hline 1983 & . & 1,31 \\
\hline 1984 & 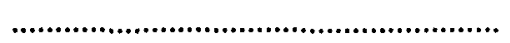 & \\
\hline 1985 & 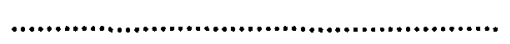 & 1,14 \\
\hline 1986 & . & ( \\
\hline 1987 & - & \\
\hline
\end{tabular}

Source: National Conference on Soviet Jewry.

several of these states had acted prior to Madrid to resolve outstanding bilateral family reunification cases, they had at the same time continued, or initiated, procedures designed to discourage emigration. In the Basket III working group, the US delegate noted with regard to the Romanian emigration process, that it had "reached the absurd point that a potential emigrant is required to submit an application in order to receive the emigration application form itself." The Federal Republic of Germany led the way in criticizing the recent imposition of higher currency exchange requirements for Western citizens traveling to East Germany. 81 
Jamming of Western radio broadcasts and working conditions for journalists captured the largest share of Western attention during the review of the information provisions of Basket III.82 The United States, United Kingdom, and Federal Republic of Germany, with the support of most other Western delegations, protested the reimposition of Soviet jamming of VOA, BBC, and Deutsche Welle in statements questioning the political weakness of regimes that went to such lengths to deny citizens access to information. The United States made the same point with regard to Soviet and East European interference with the broadcasts of Radio Free Europe and Radio Liberty. Soviet delegates countered that the West was unduly stressing certain parts of the Final Act at the expense of others, and that the flow of information would increase as detente improved.

Western delegations also protested deteriorating working conditions for journalists in the East. The United States observed that some progress, primarily in the form of bilateral agreements granting reporters multiple exit and entry visas, had occurred, but reporters still encountered obstacles to access and reporting. The United States lodged a vigorous protest over the Soviet conviction of two American reporters on charges of slander-as interpreted by the Soviet courts-and noted numerous other difficulties faced by journalists. East German authorities had, for example, adopted regulations complicating correspondent travel and making it a possible crime for citizens to communicate information to foreign journalists.

On culture and education, the East claimed it had a better record of compliance than the West. The Unit- 


\section{THE HELSINKI PROCESS}

ed States took issue with the Soviet claim that its cultural exchange program had declined for reasons beyond Soviet control. Noting the Soviet invasion of Afghanistan had made it impossible to complete negotiation of the US-Soviet bilateral cultural agreement, the US representative called for an early end to the situation which made normal relations untenable.

\section{A Media Event}

Through daily press conferences, seminars, concerts, demonstrations, symposia, art exhibits, and receptions, fifty American and European nongovernmental organizations turned the opening phase of the Madrid conference into a media event. Many prominent Soviet and East European emigres, including Aleksandr Ginzberg, General Pyotr Grigorenko, and Eduard Kuznetsov, travelled there to participate in one or more of these activities. The world press gave front page coverage to on-the-scene reports of the meeting by more than 1,500 accredited journalists, including 90 US journalists. 83

Flora Lewis, writing in the New York Times November 21, expressed the feeling of most Western journalists during the opening days of the conference:

Two weeks of the Madrid conference . . . have already shown that this time it was the Russians who made the tactical anci diplomatic mistake. ... By stonewalling bluster intended to split the West and drown out complaints of human rights violations in the East and on the invasion of Afghanistan, the Soviets managed to solidify the bickering allies, disgruntle the Warsaw Pact and draw 
even more attention to the central issues than they would otherwise have attracted.

Soviet and East European media coverage of the conference berated Western countries, particularly for raising the "unrelated" question of Afghanistan, bringing up issues which are the "internal affairs" of socialist countries, and ignoring the "most important issue of curbing the arms race." Soviet media stressed "the emphasis should be placed on reaching agreements on further practical steps to strengthen security and peaceful cooperation." Claiming the USSR wants the meeting to make balanced progress on all main provisions of the Final Act, Moscow's domestic press service charged US delegates with opposing the constructive Soviet approach.

The last week before the year-end break was a transition week, enabling the delegates both to sum up their reviews and to table new proposals for debate in the second round of the conference to convene in January. Speaking for the United States, Kampelman linked the profound transition in Europe, "in which the Helsinki Process is so important a part," and the "interrelated transition" in the United States. President Carter would soon leave office. When the US delegation returned in January, it would be under the authority of President Ronald Reagan. Ambassador Kampelman assured the assembly "American constancy to the powerful ideals of the CSCE process" would be President Reagan's objectives as they had been President Carter's. ${ }^{84}$ The adjourmment of the conference on December 19 was reported in the Washington Post the next day by Tom Bums, who noted that Western delegates were "satisfied that they had man- 


\section{THE HELSINKI PROCESS}

aged to flay the East for the invasion of Afghanistan and violations of human rights, but were apparently uncertain about the impact of their criticism."

\section{New Proposals}

More than 80 "new" proposals were tabled by delegates in Madrid the week before Christmas. Many were not really new, but repetitious of ideas floated in one forum or another during negotiation of the Final Act or at the first review meeting in Belgrade. They covered almost every imaginable aspect of EastWest relations and different interpretation of the Final Act. 85

With respect to Principles, two major Warsaw Pact proposals supported the concept of incorporating the Final Act's ten 'Principles Guiding the Relations between Participating States" into domestic and international law. The Swiss offered another experts' meeting to continue work on the peaceful settlement of disputes. Yugoslavia advanced a proposal reaffirming the Final Act as an embodiment of detente.

Western proposals attempted to strengthen and elaborate the Principles in specific ways: the United States encouraged the beginning of bilateral human rights roundtables; many Western countries advocated the removal of any obstacle to citizens monitoring compliance with the Final Act and exercising their religious rights; and the United States, Canada, and Spain called for convening an experts' meeting on human rights. Another focus of Western concern was combating intemational terrorism, as seen in a new proposal sponsored by eight Western countries, including the United States. 
Many delegations, both East and West, supported adoption of new measures in the military security field as the most effective means of furthering the Helsinki Process. Two major proposals for a post-Madrid forum on disarmament in Europe were placed in Basket 1.86 One, tabled by France and supported by nearly all NATO countries, called for a Conference on Disarmament in Europe in 1981, to adopt a coherent system of confidence-building measures applicable throughout Europe, from the Atlantic to the Urals. The US delegation, while sympathetic to many aspects of the French proposal, did not formally endorse the idea because it did not want to commit the incoming administration to such a significant new forum without an opportunity to study the proposal.

The other security proposal, put forward by Poland on behalf of the Warsaw Pact countries, called for a Conference on Military Detente and Disarmament in Europe. Envisaged as the first stage of a multistage process, the conference would convene in October 1981 in Warsaw to consider new confidence-building measures, with a second stage later devoted to arms and force reductions.

Twenty-six new and diverse proposals were placed in Basket II, covering a high-level meeting on energy (Poland and the USSR), improvement of the condition of migrant labor (Spain, et al.), improvement of business contacts (Luxembourg, et al.), encouragement of the role of small and middle-sized firms (Denmark, et al.), and development of scientific and technological cooperation (Belgium, et al.), to mention only several.87 The United States co-sponsored three proposals: on business contacts and facilities, economic and com- 


\section{THE HELSINKI PROCESS}

mercial information, and compensation trade agreements. All three proposals were designed to commit the participating states to greater adherence to principles essential for the expansion of East-West trade.

Nineteen Basket III proposals addressed the issues of human contacts (8), information (5), and cultural exchanges (6).88 The West especially supported those proposals designed to facilitate the freer movement of people and ideas-areas where current compliance was weakest. The essential elements sought by the West were contained in a package of ideas developed by the European Community, in consultation with NATO, and co-sponsored by the United States. The Western proposals, many of which were a repetition of ideas presented at Belgrade, provided that emigration requests should normally be granted, that visa fees and waiting periods should be reduced and that applicants for emigration should not be disadvantaged with regard to employment, social benefits, or other rights. In addition, the United States tabled one proposal on access to archival material and another calling for an experts' meeting on family reunification.

Eastern proposals appeared as efforts to offset Western initiatives, by matching them with an equal number suggesting action in more neutral fields, or proposing action the West would likely find unacceptable. One such Soviet proposal sought cessation of broadcasts by Radio Free Europe and Radio Liberty in an obvious effort to counter the Western information proposal, a section of which dealt with jamming. 


\section{The Worst Crisis}

When the delegates returned to Madrid in January 1981, they began the difficult task of translating the proposals submitted before Christmas into a concluding document acceptable to all 35 states. Since the Belgrade meeting had ended contentiously, with little more than an agreement to disagree and meet again in Madrid, there were great hopes the Madrid meeting would give new momentum to the Helsinki Process by adopting a set of forward-looking commitments. President Reagan named Max Kampelman to head the US delegation.

One of the first major foreign policy decisions taken by the new administration-only three weeks after the President assumed office-was to support the French proposal for a Conference on Disarmament in Europe (CDE). 89 This conference initially would negotiate a new version of the confidence-building measures of the Final Act, renamed confidence- and securitybuilding measures (CSBMs), that would be militarily significant, verifiable, politically binding, and applicable to all of Europe. At the same time, the United States and other Western states would insist that substantive commitments in the human rights field accompany any agreement on military security.

Before the three-month summer recess in July, most of the work toward an acceptable concluding document was finished: three of the four Western criteria for CSBMs-that they be militarily significant, verifiable, and politically binding-were tentatively accepted in Basket I, negotiations were virtually complete in Basket II, and provisional measures on human contacts, family reunification, and information were 


\section{THE HELSINKI PROCESS}

adopted in Basket III. Although squabbling continued on human rights, an extreme Soviet counter-proposal to include North America in the geographic area of applicability of CSBMs wrecked the opportunity for a constructive conclusion to Madrid that summer.

In a major arms control address in the fall, President Reagan reaffirmed US support for strengthening the Helsinki Process and renewed the Western motion for the $\mathrm{CDE}$ to explore new measures to enhance stability and security in Europe.90 During the late summer recess, the neutral and nonaligned countries had prepared a compromise draft of a concluding document, which succeeded in narrowing crucial East-West differences on key human rights and military security questions. Just as these countries were struggling for agreement in principle on their document, known to conference participants as RM39, on December 13 the Polish government brutally imposed martial law and suspended human freedoms throughout the country Once more the delegates reeled from the crushing impact of external events on their proceedings. Faced with their worst crisis thus far, Western and like-minded delegations could do little more in the final week of their fall session than to denounce events in Poland and adjorn, as agreed, on December 18.91

When the meeting resumed in February 1982, Foreign Ministers from virtually all Western, neutral, and nonaligned countries participated to show their outrage at the repression in Poland. US Secretary of State Alexander Haig attacked "the forcible suppression of the Polish search for freedom," stressing that this repression, "part of a broader pattern of Soviet lack of restraint," threatened the very basis of the Helsinki 
Process. How, he asked, could negotiations continue as usual on new provisions, while existing obligations were being so blatantly ignored and violated?92 Belgian Foreign Minister Leo Tindemans, speaking for the ten members of the European Community (EC), emphasized that although the EC countries continued to support the Helsinki Process, new agreements at Madrid were inconceivable while martial law existed in Poland.93

Declaring his resolute opposition to any discussion of the Polish situation at Madrid, Soviet delegation chief liyichev tried to force a "business-as-usual" negotiation of RM39, which his government had conveniently accepted during the winter recess as an acceptable basis for negotiation and eventual agreement. For a time the West was divided. Some states, including the United States, believed the session should serve to criticize violations in Poland and then recess as soon as possible to avoid the appearance of normal relations. The Federal Republic of Germany and others, at least initially, preferred to continue the meeting to keep the pressure on Poland and to avoid giving the impression the West was ending the dialogue.94 Through regular caucus meetings, the NATO countries resolved their differences and announced that at least three actions by Polish authorities were necessary before negotiations could be revived: the release of interned trade unionists and political prisoners, including Solidarity's Lech Walesa; the resumption of a dialogue between the government, the Catholic Church and Solidarity; and the lifting of martial law.

While Soviet plenary speeches were still proclaiming the necessity of resuming negotiations, Western 


\section{THE HELSINKI PROCESS}

delegates delivered some of the harshest denunciations of the Soviet political, social, and economic system ever heard in any diplomatic forum. In the twiceweekly drafting group sessions, however, NATO representatives forced a showdown through what reporters called "eloquent silence," to demonstrate convincingly that negotiations on RM39 were neither possible nor appropriate while the crisis in Poland continued. Ambassador Kampelman told Western correspondents on March 1, "there would be no normal negotiations regardless of how long the Soviet Union kept the conference in session." 95

Unable to crack strong NATO unity and perseverance-and facing nothing but further criticism at twiceweekly plenary sessions over Poland, Afghanistan, and human rights-the Soviets and their satellites had to conclude progress was impossible at Madrid under current circumstances. Thus, on March 12, the delegates decided to go home for eight months, uncertain of the future of the Helsinki Process, which at that point seemingly had collapsed. This was a time also when relations between the United States and its alliance partners remained troubled over disputes about technology for the Soviet natural gas pipeline from Siberia to Westem Europe and the political value of sanctions against the Soviet bloc.

When the meeting resumed in the autumn, the Western conditions concerning Poland for continuing negotiations had not been met. Nonetheless, Western delegates announced they were ready to continue the Madrid meeting if the East made a genuine effort to live up to its existing commitments, including real improvement of the situation in Poland. In plenary 
session November 9, the Danish Ambassador, representing the European Community, introduced five amendments to the draft concluding document which took into account the Polish situation, the continuing occupation of Afghanistan, and the dismal Eastern human rights record. The day afterwards ended a Soviet era when General Secretary Leonid Brezhnev died and Yuri Andropov, the Politburo's choice over Konstantin Chernenko, succeeded him. While formally agreeing to negotiate on what the West called "reasonable and essential" provisions, the East rejected some of them out of hand and offered only minimal concessions on others. 96

By March 1983, the atmosphere of the talks had recovered sufficently to encourage the neutral and nonaligned countries to take a further conciliatory step, by introducing a revised version of RM39 as a "basis for agreement." The revised draft reflected some of the Western proposals, notably those on trade union rights, religion, and the treatment of journalists. But key provisions such as an experts' meeting on human contacts and other provisions on human rights, which Western countries insisted would have to be part of a balanced and substantive document, were missing.97 After the Easter recess, the new head of the Soviet delegation, Vice Foreign Minister Anatoly Kovalev, praised the document, but called for unspecified improvements in it. In presenting RM39 revised, the neutral and non-aligned countries declared they had done their part; changes in the document, if any, would have to be worked out directly between East and West representatives. 


\section{THE HELSINKI PROCESS}

About this time, both sides expressed rising concern about the danger of failure to agree on a concluding document at Madrid and the consequences this might have for the Helsinki Process. Such failure certainly would delay the projected security conference, which both the Federal Republic of Germany and the Soviet Union wanted at the earliest time, each apparently believing it would assist them in their quite contrary objectives with regard to the installation of NATO intermediate range nuclear missiles in Europe scheduled to commence that autumn. When the implications of failure after such lengthy effort registered, the perception of delegates changed and the shape of agreement emerged.98

\section{End Game}

The end game at Madrid lasted for about three months. Western states announced their acceptance of RM39 revised as a basis for negotiation on April 27. The East accepted the draft on May 6, on the condition no changes would be made. Soviet agreement to the text as it stood posed a predicament for the West, which insisted on changing four words and adding two passages, one on the prohibition of radio jamming and another on convening a meeting of experts on human contacts. 99

Western delegates argued about words, because words still mattered, even after years of arduous negotiation. For instance, the ordinary person might see little reason for the West to quibble about the sentence, "The participating states express their determination to encourage genuine and positive efforts to implement the 1975 Helsinki Final Act." The West, however, 
wanted the words "genuine and positive" removed before approving the sentence. The reason was that they have become distorted in Soviet and East European dictionaries. The intention of the neutral countries which prepared the draft final document was that the sentence should demonstrate support for those trying to put the Final Act into practice, such as the Helsinki monitoring groups in the Soviet Union. The Soviets argue, however, that these groups are not making "genuine and positive" efforts, but the reverse, and therefore, the agreement will not be broken if these groups are persecuted. 100

By June 17, with the conference stalled over Soviet unwillingness to negotiate, the Spanish Prime Minister, Felipe Gonzalez, invited all the heads of delegation to his residence, where he declared the singular responsibility of the host nation to find a solution and attempted to compromise the remaining items of dispute evenly between the two sides. During the following week, support for the Gonzalez initiative grew among Western and neutral and nonaligned delegations, leading Deputy US delegation head Edward Killham to announce on June 24 the United States would "reluctantly accept" the compromise document, but would not negotiate on it.101 With new instructions from Moscow reversing the previous Soviet position of adamant opposition to an experts' meeting on human contacts, Soviet Deputy Foreign Minister Kovalev on July 1 stated his delegation's readiness to "act within the framework of the Spanish initiative, on the assumption that our partners will act just as constructively." 102 
THE HELSINKI PROCESS

By July 15, all states agreed on a 38-page concluding document, except Malta. The only remaining obstacle in the way of formal adoption of the document was the obstinate refusal of Malta to join the agreement unless its demand for a special meeting on Mediterranean security was accepted. Other states strongly opposed such a meeting, for fear Middle East issues beyond the scope of the Final Act would dominate it. The Maltese delegation changed its vote after learning that all other states had decided to proceed with a ministerial meeting to adopt a concluding document, with or without Malta. A followup to the earlier meeting on Mediterranean cooperation was programmed instead. 103

After nearly three years of exacting negotiations, in September 1983, the delegations reconvened in Madrid for closing speeches and the signing ceremony. B'nai B'rith international policy research director William Korey fairly described this occasion as "the end of the marathon, a kind of victory in Madrid." 104 But during those last few days, the prospect for a hopeful occasion was abruptly transformed into an atmosphere of sharp confrontation following the destruction of a Korean commercial airliner by Soviet military aircraft. In reference to this incident, US Secretary of State George Shultz observed "just days after accepting here a new document of still stronger commitments than those of the Final Act, the Soviet Union has ruthlessly taken the lives of 269 innocent people on a defenseless civilian airline." 105

From the same rostrum Soviet Foreign Minister Andrei Gromyko shamelessly defended the action and threatened "future intruders" with the same fate, 
which served to increase the tension and exchange of recriminations. 106 The overall result was that the meeting ended much as it had begun, on a note of uncertainty and ill will. Even the lengthy concluding document, full of promises for improved East-West relations, was largely eclipsed by the renewed confrontation.

\section{A Fairly Substantial Document}

In the final days of the meeting, one correspondent asked, "Have all these months of East-West argument and wrangling, sometimes just over a sentence or the placing of a word, been worth it?" Some critics said the agreements gained were small and insignificant, particularly at a time when East-West relations were at a low level. But most negotiators from Western and neutral countries thought that although many of them, particularly on human rights, were small steps forward, they were worth the effort to get them as building blocks for more progress in the future. 107 The text of the Madrid concluding document is given in appendix $C$.

One of the most significant achievements at $\mathrm{Ma}$ drid was the decision to convens an international conference at Stockholm in January 1984, to deal with military confidence- and security-building measures (CSBMs) and the problems of surprise military attack, which understandably continues to haunt many Europeans. The mandate for the conference was carefully structured to preclude a "disarmament" meeting in which propaganda speeches rather than constructive decisions would be the major element. The conference would be an integral part of the Helsinki Process, 


\section{THE HELSINKI PROCESS}

yet not interfere with such ongoing arms negotiations as Mutual and Balanced Force Reduction (MBFR); its first stage would deal exclusively with CSBMs designed to reduce the risk of military confrontat on in Europe, leaving "ways and a propriate means" to supplement these CSBMs for "a future followup meeting."

For Western and neutral diplomats, hard-won achievements on human rights were even more significant, especially new provisions: 108

- On monitors. New language further supports the legitimacy of monitoring groups and their activities. For example, beyond "the right of the individual to know and act upon his rights and duties in the field of human rights and fundamental freedoms," as embodied in the Final Act, the provision continues to enjoin states to "take the necessary action in their respective countries to effectively ensure this right."

- On religion. There are small but important gains over the Final Act in four areas dealing with religious freedom.

- On human contacts. Six new pledges significantly strengthen the intent of the Final Act: (1) to "favorably deal with" and "decide upon" applications for family meetings, reunification, and marriage, (2) to decide marriage and family reunification applications "within six months," the first reference to a definite time period, (3) to provide the necessary forms and information on procedures and regulations followed in emigration cases, which has been a serious problem for many trying to emigrate from the East, (4) to reduce fees charged in connection with emigration "to bring them to a moderate level in relation to an aver- 
age monthly income," (5) to assure that making or renewing applications for family reunification will not modify rights to "employment, housing, family support, access to social, economic or educational benefits," and (6) to inform applicants as "expeditiously as possible of the decision" in their cases and inform them of "their right to renew applications after reasonably short intervals" in cases of refusal. Both the fact that applicants must be informed of decisions and the recognition of the right to reapply are important because many refuseniks in the USSR have been given "final refusals" and told they should not reapply.

- On trade unions. The Final Act did not include any language on trade unions. The Madrid document reflects a Western initiative stemming directly from the suppression of Solidarity in Poland. States are to "ensure the right of workers freely to establish and join trade unions, the right of trade unions freely to exercise their activities and their rights."

- On access to diplomatic missions. Visitors to diplornatic and other official missions will be assured access to them.

- On information. Five practical steps were added on information, culture, and education and ten on the improved treatment of journalists.

- On terrorism. The Final Act does not deal directly with terrorism. The United States joined Spain and others in requiring effective state measures for preventing and suppressing terrorism, for preventing their territories from being used for organizing terrorist activities, and for refraining from directly or indirectly assisting, financing, encouraging, or tolerating terrorist or subversive activities. 


\section{THE HELSINKI PROCESS}

The Madrid document also endorsed six supplemental meetings: a second experts' meeting on the peaceful settlement of disputes in Athens in 1984; a second meeting on Mediterranean cooperation in Venice in 1984; an experts' meeting on human rights in Ottawa in 1985; a commemorative meeting in Helsinki in 1985 marking the tenth anniversary of the signing of the Final Act; a cultural forum in Budapest in 1985; and an experts' meeting on human contacts in Bern in 1986.

Not covered in the concluding document were two important issues on which delegates could not agree: barring the jamming of foreign radio broadcasts and specifying that foreign journalists should not be expelled for the content of articles they or their newspapers have published.

For most of the Madrid meeting, the Soviet Union and its allies, unlike the Western and neutral and nonaligned delegations, refused to commit themselves to continuing the Helsinki Process, by agreeing to the date and place of the next review meeting. Instead, they linked their agreement upon what they considered a "successful" outcome at Madrid, meaning the meeting had to produce a major military security conference. 109 This tactic obviously was an attempt to intimidate the other participants into believing the Helsinki Process would end if the Madrid meeting did not conclude to Soviet satisfaction. Near the end, however, with the Stockholm meeting in hand, the Soviets approved provisions in the concluding document for another review conference in Vienna beginning in November 1986. 
On the whole, the results of the Madrid meeting were mixed. On the plus side, the meeting ended with a balanced and substantive concluding document that had eluded the delegates at Belgrade. It provided the security meeting sought by the Soviets, and experts' meetings on human rights and human contacts sought by the West. At the same time, Madrid failed to produce any credible sign the Soviet Union intended to regard its new commitments any more seriously than its existing obligations under the Final Act. In fact, Soviet behavior with respect to the Act, ranging from curtailed emigration to increased political oppression, had fallen to its lowest point since 1975.110 The fact the Helsinki Process could survive this record meant the participating states still valued its potential for continuing dialogue on East-West problems and for achieving progress when international relations improved. 
Four

\section{Progress at Stockholm}

AFTER THE NONMIIITARY SIDE of the Helsinki Process was reinforced at Madrid, the challenge at Stockholm became to strengthen its obligations in the military security field. Delegates at Stockholm achieved this goal by unfolding the confidence-building measures of Helsinki into confidence- and securitybuilding measures (CSBMs), signaling a change in emphasis from quasi-military, largely voluntary measures flowing from political considerations to more militarily significant, mandatory measures intended to promote military as well as political confidence. Ambassador James Goodby, representing the United States at the beginning of the Stockholm conference, dubbed this change "a new approach to arms control." 111

The Conference on Confidence- and SecurityBuilding Measures and Disarmament in Europe (CDE) opened in Stockholm's Kulturhuset on January 17, 1984, as scheduled, to begin the first stage of its mandated work, the "negotiation and adoption" of a set of mutually complementary measures designed to "reduce the risk of military confrontation in Europe." The second, or "disarmament" stage of the negotiation, would not commence until after the Helsinki followup conference at Vienna had reviewed the Stockholm results and decided to continue the CDE.

The meeting itself marked an important expansion in the scope of East-West negotiations and a turning 


\section{THE HELSINKI PROCESS}

point for the better in Soviet-American relations. In his opening statement to the conference, US Secretary of State Shultz called for an open and comprehensive dialogue with the East and help with "healthy balance and perspective" from the neutral and nonaligned delegations, to make progress toward the goal of reducing the danger of surprise attack, miscalculation, or misunderstanding. 112

\section{Four Proposals}

Following the first week of opening statements, the NATO allies demonstrated their "seriousness of purpose" by promptly tabling a package of six CSBMs, all said to be militarily significant, politically binding, verifiable and applicable to the whole of Europe from the Atlantic to the Urals. The NATO initiatives were characterized as "concrete, practical and realistic measures, not unverifiable declarations of good intent or repetitions of commitments already undertaken in other agreements." 113 Specifically, they were intended to enhance regional trust and security in six ways:

- First, by providing information about military forces, including the structure of major military units. This would provide a common framework for the other measures and mutual understanding of the significance of particular military activities.

- Second, by previewing military activities annually, including important activities planned for the next year. This would help to clarify whether an exercise in time of tension had been planned long in advance or perhaps was meant as a warning to other states, as the case of Zapad in August 1981, one of the 
largest Soviet exercises since World War II involving 100,000 troops to intimidate Poland.

- Third, by requiring notice of important military activities 45 days in advance. This would help to clarify whether activities were routine or possibly threatening.

- Fourth, by calling for observation of military activities, involving invitations to other states to send observers to all important military activities.

- Fifth, by trying to ensure compliance and verification, including a commitment not to interfere with a state's national technical means of verification and a requirement for monitoring compliance through the use of small monitoring teams.

- Sixth, by mandating improvement of the facilities for communication among the 35 participating states.

These CSBMs were important because they promised to improve the quantity and quality of militarily significant information available to prevent crises or to contain or resolve them, should they occur, including detailed information from the states themselves and corroborative information from trained observers, national technical means, and monitoring teams. NATO members advanced these measures because they would lead gradually to greater transparency or as the Belgian Ambassador at Stockholm put it, to the "demystification" of military activities on the continent of Europe. 114

Ambassador Goodby explained the significance of the NATO measures by contrasting them with "classical" arms control measures involving force "levels." The new ideas presented at Stockholm dealt with force 


\section{THE HELSINKI PROCESS}

"operations." In contrast to "classical" arms control agreements promoting long-term stability, the agreement sought by the Western allies at Stockholnı would promote short-term stability, that is, stability during periods of intense and possibly turbulent international political developments. 115

As the heads of delegation from the alliance took turns in explaining the NATO package in daily plenary sessions, the Romanian government, following a nonpartisan foreign policy, tabled a proposal independently of the Warsaw Pact. The Romanian initiative included a number of concrete, verifiable measures not unlike those previously introduced by NATO, others designed to limit military activities, and still others of a declaratory nature hewing to Soviet interest in nuclear-weapons-free zones and a non-use of force treaty.116 By supporting some Western proposals, the government of Romania seemed as much concerned about attack from its Warsaw Pact allies as the threat from EastWest conflict, even though the country almost certainly would be caught in the middle of any such conflict.

The neutral and nonaligned nations presented their own proposal early in March amidst yet another change in Soviet leadership. Soviet leader Yuri Andropov died in February and Brezhnev's protege Konstantin Chernenko succeeded him, marking the end of a brief period of internal reform. Neither the Romanian nor the neutral and nonaligned proposal mentioned banning first use of nuclear weapons, which Soviet Foreign Minister Andrei Gromyko had set as a goal for the meeting in his opening statement. These salutary omissions benefitted the Western allies, because before the Stockholm meeting commenced, NATO had ruled out 
any alliance discussion of nuclear weapons at Stockholm. The neutral and nonaligned initiative for the most part built upon the confidence-building measures of the Final Act, a starting point welcomed by the West. 117

At the beginning, the East sought unsuccessfully to use the conference as a forum for denouncing NATO's deployment of intermediate range nuclear missiles, which had commenced the previous autumn. The Soviet package of six proposals, numerically matching those of NATO, did not come until May 8, after the Easter recess. 118 In that package, the Soviets called for unspecified improvements in the confidence-building measures adopted at Helsinki, a treaty on non-use of force in Europe, a pledge against first use of nuclear weapons, a ban on chemical weapons use in Europe, nuclear-weapons-free zones in Europe, including the Balkans and the Baltic, and subsequent reductions in military spending.

Only the proposal for improvements in confidence-building measures referred to by the Soviets as "military-technical" measures, resembled any one of the NATO proposals. The remaining ones were in NATO terminology "declaratory measures"-general pledges not to do something-and the last three concerned matters clearly outside the CDE mandate.

One troubling aspect of the Soviet package was its emphasis on nuclear weapons, directly challenging NATO's resolve to use nuclear weapons first, if necessary, to counter a Warsaw Pact attack and contrary to NATO's decision to exclude nuclear discussions at Stockholm. Ironically, the Soviets had promptly left the US-Soviet negotiations in Geneva on strategic and 


\section{THE HELSINKI PROCESS}

intermediate range nuclear forces when NATO's deployment of US cruise and Pershing missiles commenced in Europe in late 1983. The Western countries recognized soon after the Soviet proposal hit the table, that the dissimilarity of concepts for the meeting, not to mention individual proposals, meant a long meeting ahead.

In response to the Soviet interest in a non-use of force agreement, President Reagan told the Irish Parliament in June "if discussions on reaffirming the principle not to use force ... . will bring the Soviet Union to negotiate agreements which will give concrete, new meaning to the principle, we will gladly enter into such discussions." 119 But the Soviets held back at that time.

\section{The Long Stall}

One of the problems the Stockholm conference faced from the beginning was the lack of something like the Yellow Book of Belgrade or the Purple Book of Madrid containing agreed rules of procedure. A preparatory meeting held for too brief a time before the conference failed to decide such important details as procedures for establishing conference working groups. This lapse led to seemingly endless procedural wrangling, lessening the time available for debate of the substantive issues.

The impasse over procedural details essentially lasted throughout the first year, although by December 1984, the delegates finally agreed on working groups to move the meeting from plenary oratory to detailed discussion. But when the conference resumed after a holiday recess in January 1985 and NATO members 
resumed trying to explain more fully their proposal, they met a barrage of criticism. Eastem delegates charged the NATO countries with being primarily interested in "spying" on the East through the information provisions of the allied package and repeated their call for a non-use of force/no-first-use of nuclear weapons treaty. 120 Meanwhile, Ambassador Robert Barry succeeded Ambassador Goodby as head of the US delegation and shortly afterwards Mikhail Gorbachev succeeded Soviet General Secretary Chernenko, who succumbed to a heart attack after only 13 months in office on March 10.

To give impetus to the conference once again, President Reagan repeated to the European Parliament in Strasbourg in May 1985, the offer originally made in Dublin "to discuss the Soviet proposal on nonuse of force in the context of Soviet agreement to concrete confidence-building measures." 121

By autumn, under General Secretary Gorbachev, Soviet delegates appeared to adopt less obstructionist and propagandist tactics. Although not formally withdrawing their numerous declaratory measures introduced in 1984, they concentrated discussion only on non-use of force. And they explained their own CSBMs with greater precision, including the requirement for $\mathbf{3 0}$ days advance notification of ground maneuvers and military movements involving more than 20,000 troops, independent air activities involving more than 200 aircraft in the air at any one time, and independent naval maneuvers involving more than 30 ships. Even with numbers far apart from similar NATO measures, the obvious shift away from declaratory measures in favor of confidence-building proposals 
THE HELSINKI PROCESS

signaled to the West a positive change in Eastern attitude toward the CDE. 122

About the same time, further evidence appeared that the East was giving the Western and neutral and non-aligned proposals more thought. In Paris on October 3, General Secretary Gorbachev announced the Soviets were prepared to accept "mutual exchanges of annual plans of military activities subject to notification." 123 At the Geneva summit meeting in late November, President Reagan and General Secretary Gorbachev spurred the Stockholm proceedings by stating in their joint communique "their intention to facilitate ... a an early and successful completion of the work of the conference," including "mutually acceptable confidence- and security-building measures" and "the principle of non-use of force." 124

Sensing a growing inclination for compromise, the neutral and nonaligned states tabled a revised version of their earlier proposal, striking a perceptive balance, even if not entirely acceptable to the West, to keep the focus of negotiations on concrete CSBMs. Delegates thus ended the year more hopeful than the year before, but with scarcely anything to show for their two-year effort.125

By the spring of 1986, the shape of an agreement began to emerge, even with five crucial issues remaining for decision: the type and level of military activities requiring notification, observation, inspection, and constraints. With the Stockholm meeting scheduled to adjourn September 19, in time to report its results to the Vienna review meeting convening November 4 , time was running out for compromise and drafting a concluding document. The Soviets continued to hold 


\section{PROGRESS AT STOCKHOLM}

back in an apparent effort to build pressure for the end game. 126

On May 1, the Irish delegation advanced a "time constraint" that did not exclude large-scale exercises, but provided for their notification farther in advance. The formula was well designed to assure that legitimate training activity would be permitted, while discouraging sudden displays of force that could possibly be intimidating. The initiative built on the Swedish "bonus" concept, favoring activities announced well in advance. Such activities would be less constrained than those held on shorter notice, thus discouraging sudden, unexpected behavior. ${ }^{127}$

To "unblock the road ahead toward an agreement," Canadian Ambassador W. T. Delworth, representing the 16 NATO members, offered an overall compromise on "outstanding issues" in June. 128 Shortly thereafter, Soviet head of delegation Oleg Grinevsky announced Eastern readiness "to consider the issue of inspection," and in late August, agreed to aerial inspection. 129

The essential issue of notification thresholds was not resolved until the last day of the conference, Friday, September 19, and then only after stopping the clock to avoid technical adjournment. Delegates reached agreement over the weekend on notification thresholds, observation levels, and inspection quotas, adjouming at noon on Monday. The head of the West German delegation, Klaus Citron, remarked afterwards, "nothing helps so much as a date when you have to deliver your homework." 130 


\section{THE HELSINKI PROCESS}

\section{A Significant Agreement}

The Stockholm agreement, the first arms control agreement since SALT II, was a landmark achievement for arms control and the Helsinki Process. Because it narrows the possibilities for conventional aggression at the outset, it represents an important first step toward a more stable military environment in Europe. ${ }^{131}$ Reflecting more the Western than the Eastern agenda, the agreement includes the following provisions:

- On notification: $\mathbf{4 2}$ days or more prior notification of military land force activities throughout Europe involving a divisional structure or two or more brigades/regiments and at least 13,000 troops or 300 tanks; 200 or more sorties by aircraft, excluding helicopters; or amphibious landings or parachute drops involving 3,000 troops.

- On observation: mandatory invitation of observers from all Helsinki states to notified land force activities above a threshold of 17,000 troops or a threshold of 5,000 troops for amphibious lantings or a parachute assault by airborne forces.

- On forecasting: the exchange of an annual calendar of all notifiable military activities, not later than 15 November for the following year. Two constraints are imposed: large scale activities involving more than 40,000 troops must be announced in the annual calendar at least one year in advance and those involving more than 75,000 troops, two years in advance. Otherwise, they are prohibited.

- On compliance and verification: on-site inspection from the air or ground, or both, as the means of verifying compliance with agreed measures, with no right of refusal. No state will be obliged to accept 


\section{PROGRESS AT STOCKHOLM}

more than three inspections per calendar year and no more than one inspection from the same state. A state must give a reason for its inspection request, but any dispute concerning the validity of the reason will not prevent or delay the conduct of an inspection. The reply to any request will be given within not more than 24 hours and within 36 hours the inspection team will be permitted to enter the territory of the receiving state.

The issue over the Soviet proposal on refraining from the threat or use of force was resolved by including it in the agreement. Western delegates successfully reoriented it, however, to reflect a more balanced approach to security, including reference to human rights, antiterrorism, compliance with international commitments, and new barriers to the Brezhnev doctrine, by requiring that states belonging to the same alliance refrain from the threat or use of force vis-a-vis each other. 132

The obligatory measures adopted in the Stockholm document mark a significant advance over the largely voluntary measures contained in the Final Act and transform the concept of confidence-building into practical procedures. The zone of application for CSBMs has been expanded to cover more than 1,000 miles of territory east to the Urals. The troop threshold for advance notification has been cut almost in half from that adopted in Helsinki-from 25,000 to 13,000 and elements of structure and equipment have been added to the numerical threshold to make it more militarily significant and verifiable.

States are required to forecast plans a year or more in advance and to give much earlier notification 


\section{THE HELSINKI PROCESS}

of their military activities, 42 days compared to 21 . Observation has been made mandatory for activities over a given threshold. The most significant advance was the provision for on-site inspection without right of refusal. This is the very first East-West accord in which the Soviet Union has agreed to verification of military activities on its territory. If faithfully implemented, the detailed provisions of the Stockholm document can make military activities in Europe more predictable and inhibit opportunities to use military force for political intimidation. 133

The Stockholm document, however, does not incluat everything the West wanted, nor does it exhaust the potential for even better CSBMs. On the issue of inspection, the East rejected the neutral and nonaligned states' offer to provide neutral aircraft and crews. With respect to information exchange, the conference did not achieve nearly as much as might have been expected. As Ambassador Barry observed in his closing statement, "it seems to us self evident that an agreed understanding of what forces are routinely stationed in Europe, with what combat capability, is a fundamental requirement of true stability." 134

In announcing the positive outcome of the CDE conference on September 22, 1986, President Reagan linked progress in the military security field at Stockholm with "balanced progress on human rights and fundamental freedoms" at the Vienna review meeting beginning in November.135 By advancing the principle of openness in the military security field, the Stockholm accord contributes to lowering the artificial and real barriers which divide Europe. But this advance in one area of the Helsinki Process highlighted the 


\section{PROGRESS AT STOCKHOLM}

need for real progress at Vienna on human rights and fundamental freedoms, where the East's compliance record was severely flawed. The future of the $\mathrm{CDE}$ conference depended upon balanced progress at Vienna in all fields of the Helsinki Process. 
Five

Ottawa, Budapest, and Bern

IN THE MONTHC PRECEDING the Ottawa meeting, the Soviets seemed to scorn their enlarged human rights commitment at Madrid.136 Not only was there no let-up in the persecution of dissidents, refuseniks (Jews previously denied permission to emigrate), and religious activists, but suppression of national minorities and harassment of political prisoners and their families continued unabated. Moreover, Soviet authorities continued to amend the legal code to outlaw independent forms of expression and to sever contacts between Soviet citizens and foreigners.

One of the most dramatic confrontations over basic rights occurred in the Soviet Far East. An entire ethnic-German Pentecostal community, consisting of more than 20 families, banded together in hunger strikes for two months, to protest their inability to worship freely and to gain Soviet permission to leave and join relatives in the Federal Republic of Germany.

Andrei Sakharov and his wife Yelena Bonner remained in isolation, confined to the closed city of Gorky and denied contact with friends and relatives. Natan Shcharansky was confined in the internal prison of a labor camp. Yuri Orlov remained exiled and isolated in the desolate province of Yakutia, while many other human rights activists remained prisoners, some with newly extended terms. Political prisoners often endured strict confinement and frequently were not 
permitted family visits or letters. Soviet abuse of psychiatry for political purposes continued, as did poor conditions in labor camp cells and some beatings. Later, Ukrainian dissident poet Vasyl Stus died in a labor camp in September 1984.

Soviet authorities exerted steady pressure to encourage Muslims of Central Asia and Azerbaijan to abandon their religion and use the Russian language. Very few mosques in these regions remained open for use, and there were few officially recognized clergymen. Muslim clergy not sanctioned by the authorities were attacked in the official press as "vagabonds." One of them, Akverdy Eshkulov, was reportedly arrested in the Samarkand region and sentenced to two years in a labor camp for serving as a mullah without official sanction.

Across the Soviet Union a harsh campaign continued against Hebrew teachers and Jewish cultural activists, bringing the number of Jewish political prisoners to at least 22. Since teaching Hebrew is not illegal, the authorities continued the practice of finding such pretexts for arrests as "anti-Soviet slander." As shown in Chapter 3, Jewish emigration from the Soviet Union remained low at this time. Soviet authorities continued to maintain, despite contrary evidence, that the vast majority of Jews who wished to leave the country had already left, so the rate of emigration was declining naturally. In other Warsaw Pact countries the human rights record was mixed. In a few positive developments, Poland, the German Democratic Republic, and Bulgaria seemed to take the problem of family reunification more seriously. The Bulgarian Government resolved 14 out of 16 family reunification cases 
OTTAWA, BUDAPEST, AND BERN

represented by the United States. A Czechoslovak amnesty reduced the sentence of four political prisoners by up to one year. The Romanian government allowed Father Gheorghe Calcin-Dumitreasa to emigrate with his wife and son to the United States after he had spent five years in jail and a year under house arrest.

Negative tendencies continued also. The number of political prisoners in Poland doubled in six months, with most new arrests apparently aimed at Poland's flourishing underground publishing industry. In Czechoslovakia, the government denied permission for Pope John Paul II, as well as cardinals from Austria, France and the United Kingdom, to attend ceremonies marking the 1100th anniversary of the death of St. Methodius. The Hungarian government granted its police unrestricted power to watch and exile internally any adult citizen whose "attitude" posed a permanent danger to internal order and public security. The Bulgarian government continued its campaign to assimilate the Turkish minority, using its militia to enforce curfews, conduct arrests and interrogations, and imprison ethnic Turks who refused to give up their cultural identity. Romanian authorities sentenced five persons to prison terms ranging from ten months to seven years for "Bible smuggling."

\section{Ottawa on Human Rights}

As the first experts' meeting devoted exclusively to human rights, the Ottawa conference allowed its delegates only six weeks-from May 7 to June 17, 1985to consider previously intractable questions concerning "respect, in their states, for human rights and fundamental freedoms, in all their aspects, as embodied 


\section{THE HELSINKI PROCESS}

in the Final Act." With such a broad mandate and little time, the delegates from East and West commenced at once to debate inconclusively the two main themes common to continuing disagreements over human rights throughout the Helsinki Process:

- First, the proper cause-effect relationship between human rights and international relations. In his opening address, referring to the connection between human rights and relations between the states, Soviet Ambassador Vsevolod Sofinskii argued that detente leads to greater respect for human rights, and international tension leads to the suppression of human rights, the reverse of the cause-effect relationship based on Western values. US Ambassador Richard Schifter explained the Western view that "respect for human rights in individual states contributes to the improvement of international relations .... disrespect for human rights contributes to the deterioration of international relations." 137

- Second, the proper interpretation of civil, political, economic, social, and cultural rights, all characterized as "human rights" in the UN Declaration of Human Rights and in Principle VII of the Final Act under the heading "human rights and fundamental freedoms." The Western concept of human rights has evolved from English and French tradition that nations came into existence to protect the most basic rights of their citizens. These inalienable rights, known to Americans as "life, liberty, and pursuit of happiness" have been called "birth" or "natural" rights, that is, rights so basic they cannot be created by government, but only protected and certainly not taken away. 
In Helsinki terminology, these are "civil and political rights."

Although showing signs of change, the Soviet concept of human rights differs. In the Soviet Union duties come before rights and economic and social rights have higher value than civil and political rights in Soviet life. The Soviet delegation thus insisted that such matters as employment, housing, and social justice deserved equal debate at Ottawa. Subsequently, Ambassador Sofinskii's attack on the social records of Britain and West Germany caused bitter East-West arguments. ${ }^{138}$

The controversy continues because economic, social, and cultural rights, which have come to the fore in international discourse only since World War II, exist outside the Western tradition of human rights. The Soviet Union and other Eastern states have abused the Western concept of human rights by claiming to promote the economic and social rights of their citizens, while simultaneously repressing their civil and political rights. Clearly no category of rights should be allowed to become an excuse for the denial of other rights. Even if economic, social, and cultural rights have been legitimized through UN and other agreements, Western delegates have to guard against continuing debate over other legitimate rights, diluting commitments to what Western nations have called for two centuries "natural rights." 139

In parallel with the debate on human rights themes, for three weeks the Western countries critically reviewed the Eastern human rights record, criticizing particularly flagrant abuses of freedom of expression, religious liberties, and discrimination against national 


\section{THE HELSINKI PROCESS}

minorities. Certainly by that time, if not before, the Soviets had decided "to tough it out at Ottawa." 140 Although the Madrid mandate for the meeting called for "Conclusions and Recommendations," Ambassador Sofinskii rejected out of hand both the proposal for a final document of the NATO members and European Community and that of the neutral and nonaligned states, which also was acceptable to the West.

At the end, the neutral and nonaligned states stood with the West in preferring no final document to one which compromised principles or papered over differences. This anti-climax was hardly a Soviet victory, however, for the common human rights agenda evolved by the West from 45 separate proposals at Ottawa would reappear at Vienna, with Western unity and resolve stronger than ever. ${ }^{141}$

Ambassador Schifter told the Soviet delegation privately during the meeting that if the Soviet Union wanted better relations with the United States in any field, the USSR must improve its human rights record, because that is increasingly being used as a standard to measure the relationship.

\section{Budapest on Culture}

The Cultural Forum meeting in Hungary's capital city for six weeks in October and November 1985 was as disappointing to the West as the human rights conference in Canada. The differing conceptions of culture, which divided East from West from the start of the meeting, were captured by the head of Great Britain's delegation, Norman St. John Stevas, in his opening statement: "There is no such thing as socialist 
art or capitalist art, there is good art and bad art, that is all." 142

The West proposed an agenda adhering to the Madrid mandate to "discuss interrelated problems concerning creation, dissemination, and cooperation, including the promotion and expansion of contacts and exchanges, in the different fields of culture." Eastern diplomats argued to narrow this scope to emphasize the "promotion and expansion" of cultural cooperation, presumably to deflect Western criticism of the pervasive denial of self-expression in artistic and cultural endeavors in the East.

Vastly different conceptions of cultural rights, which the West wished to debate and the East wished to avoid, complicated any agreement. Western nations, for example, believe all peoples and national minorities should have the unquestioned right to pursue their cultural heritage, including the teaching of language as an integral part of self-expression. Yet in the Soviet Union, public discussion of the history, religion, or literature of minority nationalities has been officially labeled "bourgeois nationalism" and repressed as antiSoviet or subversive. Moreover, Soviet law forbids religious indoctrination outside the home and, as noted previously, a wave of arrests and trials in 1985 swept 22 Hebrew teachers and Jewish cultural activists into prison.

Access by Soviet citizens to foreign culture represented another area of dispute. The selection of foreign books and films for internal distribution has been highly restrictive, eliminating those critical of the Soviet Union and circulating those reflecting poorly on the United States. Soviet officials also determine which 
books may be exhibited at book fairs. At the Moscow Book Fair in 1983, for example, to deter religious expression, Sovie: officials seized 49 books from the stand of the American Jewish Publishers.

After prolonged debate, a compromise agenda consisted of four parts: the plastic and applied arts, including the preservation of cultural and histoncal monuments; the performing arts, including film, radio, and television; literature, including translations, especially of less widely spoken languages; and mutual cultural knowledge. 143 Because the Madrid mandate expressly called for attendance "by leading personalities in the field of culture from the participating states," the Soviets grudgingly accepted Western delegations comprised both of government officials and leading artists.

The Budapest meeting became another experience in the Helsinki Process of "political non-communication." Western delegates emphasized the right of national minorities and religious groups to preserve and develop their particular cultures and condemned censorship, jamming, restrictions on travel and impediments to access to newspapers, journals, and films. For their part, Eastern delegations delivered long speeches citing cultural accomplishments and stressed the "historic responsibility" of artists for peace. The Soviets and some of their Warsaw Pact allies sought unsuccessfully to divide the Western states by referring none too subtly to a Furopean cultural unity, implicitly excluding North America. 144

Looking back at the Budapest meeting a year later, the Soviet Committee for European Security and Cooperation charged that "certain Western countries, 
above all the USA, plainly did not seek mutually acceptable accords with the socialist countries but tried to turn the Cultural Forum into a kind of trial, use it for propaganda purposes and interference in the internal affairs of the socialist countries." 145

Although a final document was not required by the Madrid mandate, Western delegates "worked concientiously until the very end to produce one." But even with the help of encouraging communication among cultural figures from the 35 states, basic disagreements resulting from entirely different systems and ideologies stood in the way of a good document. A senior member of the Soviet delegation, Sergei Kondrashev, called it "a pity" there had been no results in Budapest, but "this did not mean the end of the Helsinki Process . . . the Soviet Union believes in these discussions and does not want to see them fade away." Most delegates, including US Career Ambassador Walter Stoessel, seemed to believe that Budapest had been one of the more successful meetings in the Helsinki Process, despite its failure to produce a final document.146 In any case, the text produced by the West would become the springboard for Westem discussion of cultural issues at Vienna.

\section{Bern on Human Contacts}

Despite long odds after Ottawa and Budapest, the Bern meeting exceeded Western expectations in achieving practical results in improving the lives of ordinary people. The Madrid concluding document had specified, at Western insistence, the experts' meeting on human contacts at Bern in April-May 1986, "to discuss the development of contacts among persons, insti- 


\section{THE HELSINKI PROCESS}

tutions and organizations." Reflecting the encouraging tone of the meeting between General Secretary Gorbachev and President Reagan in Geneva in November 1985 , the Soviet delegation promised a new "spirit" and new "practices" in the field of human contacts, and took a positive stance toward the outcome of the meeting. At the end, however, Western unity faltered and the United States stood alone in not giving approval to the final document accepted by 34 countries, thus disappointing Western and Eastern Europeans alike. 147

Veterans of the Helsinki Process said the Bern review of compliance, reinforcing Western values of accountability, was the most thorough, objective, and calm of any in its history. The issues covered were reunification of families, family visits, binational marriages, freedom of movement (including emigration), contacts among members of religious faiths and national minorities, trade union contacts, the development of tourism, and youth and sports exchanges. In discussing practices and methods approved on paper at Helsinki and Madrid, but frustrated by daily reality, the debates were honest and candid.

The Soviet Union used the Bern meeting as an occasion for taking humanitarian action helping some 200 individuals. The Romanian delegation resolved a large number of the 27 specific cases presented by the United States at Bern, and by June 1, had approved for emigration nearly 1,200 people from the US representation list. The Bulgarians had resolved favorably 12 of 18 US cases the week before the Bern meeting opened. 148 
OTTAWA, BUDAPEST, AND BERN

Following debate on 49 proposals, including 24 from the Warsaw Pact states, the NATO members and the European Community presented a draft concluding document recommending 20 practical steps for adoption. Later the neutral and nonaligned countries submitted a compromise draft which subsequently was endorsed by all countries except the United States. Negotiations continued until $40^{\prime}$ 'clock in the moming of the day the conference was to end, May 26, when the Soviets broke off the talks.

US Ambassador Michael Novak, in restımony later before the Helsinki Commission, referred to the Bern compromise as a "pale imitation" of the strong Western proposal and characterized it this way: "some of its proposals merely repeat Helsinki provisions already violated; some of its provisions are weaker than or more flawed than Helsinki; some, such as the one on religion, would have established possibly damaging precedents; and a few, at best, went modestly beyond Helsinki."' 149

The Soviet Committee for European Security and Cooperation in July 1987 gave a different account of the Bern closing, asserting that on the last night the compromise draft was tentatively approved by all delegations, including the US delegation, and only hours before the official closing ceremony Washington defiantly vetoed the final document. The Committee summed up the proceedings of $t^{\prime}$ meeting by contrasting the "broad, constructive Soviet approach to the solution of major problems of mankind" with US behavior ignoring "the will and interests of other peoples" and "wrecking the Bern accords . . . in opposition to the whole of Europe." 150 


\section{THE HELSINKI PROCESS}

Regardless of the lack of a final document, the Bern debates above all revealed the force of Western ideals-common humanitarian values and conscienceand the common interest of governments in upholding them. The basic appeal of these ideals has encouraged the East to respond in the same humanitarian language, which most Western delegates would agree offered the best hope over time of improving Eastern behavior.

The debates at Ottawa, Budapest, and Bern paved the way to Vienna. On the occasion of the 11 th anniversary of the Helsinki accords, on August 1, 1986, President Reagan stated, "we will work to ensure that the upcoming meeting in Vienna will mark a step toward making the promises of Helsinki's first decade a reality in its second." 151 
Six

Inspiration for Change at Vienna

FEDERAL CHANCELLOR FRANZ VRANITZKY cordially welcomed the foreign ministers and their national delegations to Vienna and opened the third Helsinki followup meeting at the Hofburg on Tuesday, November 4, 1986. In his opening address to delegates, he acknowledged the past "great expectations, often bitter disillusionment, and at times exhaustion," but urged new "tenacity, perseverance and a high degree of patience" for their dialogue ahead, to mark the Final Act as more than "a symbol of confidence and hope for a peaceful Europe." 152

\section{A Promising Start}

Sir Geoffrey Howe of Great Britain, speaking for the European Community, prompted delegates to check what had been done, before devising plans for the future, and, by all means, to do something for "ordinary people." 153 French Foreign Minister Jean-Bernard Raimond recalled France's "constant policy in Europe" for a quarter of a century, independent of the "ups and downs of East-West relations" and quoted General Charles de Gaulle on bringing ideals face-to-face with the constraints of reality: "One can do nothing serious if one succumbs to idle dreams, but what great things can be done without them." 154 


\section{THE HELSINKI PROCESS}

In one of the longest speeches to the assembly, West German Foreign Minister Hans-Dietrich Genscher observed that 11 years after signing the Final Act, "we are on the right path." If the Final Act is fully implemented in good faith, Europe could "regain its unity" and realize "its destiny, despite all the vicissitudes of history." The line that divides the Europeans also divides the Germans, but the Helsinki Process offers the Federal Republic hope for a state of peace in which Germany "regains its unity through selfdetermination." 155

US Secretary of State George Shultz announced he had come to Vienna "to reaffirm the determination of the United States to work energetically and in concert with our friends in support of full implementation of the principles of the Final Aci." He reminded delegations of the genius of the Final Act-the mandate for "balance between the related problems of military security, political confidence, economic cooperation, fundamental human rights and freedoms, and contacts among people"-and that "escape from the violation of existing commitments cannot be found in the flight to new commitments," what Senator Claiborne Pell earlier called "escaping forward." Secretary Shultz also introduced Ambassador Warren Zimmermann, "one of our most able veterans of CSCE diplomacy" as head of the US delegation. 156

Soviet Foreign Minister Eduard Shevardnadze called for "new political thinking" building on the positive results of the Reykjavik meeting in October 1986 between President Reagan and General Secretary Gorbachev, which would make the Helsinki Process "a kind of model for establishing a system of com- 
CHANGE AT VIENNA

prehensive security." He envisioned the Helsinki Process also "as promoting more democratic relations between states and greater democracy in public life within each country." $\mathrm{He}$ asserted the Soviet Union attaches "permanent significance" to the seventh principle of the Helsinki Final Act concerning respect for human rights and fundamental freedoms, charged the United States with "systematic and massive" violations of human rights, and surprised the assembly by proposing a forum in Moscow "to consider the whole range of these problems, including human contacts, information, culture, and education."' 157

The generally positive statements of the foreign ministers gave the Vienna meeting a promising start. Even earlier, the meeting began ivell for Western delegates at the preparatory session when favorable decisions were taken on several procedural issues which had caused significant friction at Belgrade and Madrid. One of these decisions contributed to greater "openness" of the proceedings by opening plenary meetings to the public at the end of each conference phase, as well as the beginning, as in the past. Another extended the review of implementation from five to seven weeks. And a third made an ironclad commitment of the states to a further followup meeting after Vienna. 158

Other actions before the start of the conference contributed to its successful beginning. Soviet authorities resolved the cases of two prominent prisoners of conscience: Moscow Helsinki group leader Yuri Orlov and noted poet Irina Ratushinskaya. Linked to the Daniloff-Zakharov journalist-spy exchange, Yuri Orlov suddenly was transferred from his place of Siberian 


\section{THE HELSINKI PROCESS}

exile to Moscow. Following his arrival with his wife in the United States on October 5, Orlov was hailed by President Reagan at the White House as a "hero of our time." Soviet authorities released Irina Ratushinskaya from labor a camp on October 9, after which she and her husband were allowed to travel to England for her needed medical treatment. On the eve of the Vienna meeting, the longest standing refusenik case ended when Soviet authorities allowed Benjamin Bogomolny to emigrate with his wife.159

\section{Critical Review}

As the review began, Western delegations were generous in giving the Soviets and their allies credit for timely humanitarian gestures, mainly in hope of encouraging further good behavior. But such moderation did not diminish the intensity of the review of Eastem compliance with the Helsinki Final Act and Madrid Concluding Document. The examination was rigorous, particularly in the field of human rights after the death of imprisoned dissident Anatoly Marchenko on December 8, two days before International Human Rights Day and amid indications he was going to be released. After years in Soviet labor camps, in 1967, he authored "My Testimony," the first exposé of post-Stalin camps; nine years later he helped to found the Moscow Helsinki monitoring group; and, in 1981, a Soviet court sentenced him to ten years camp plus five years exile for "anti-Soviet agitation and propaganda." In an appeal he smuggled out to participants in the Vienna meeting, he called his treatment "an assembly line to annihilation." Marchenko died of unknown causes in Chistopol prison.160 
Some neutral and nonaligned participants were so outraged by the Marchenko affair that, for the first time, they singled out the Soviet Union and its victims by name. In the most concentrated attack on human rights abuses since the beginning of the Helsinki Process in 1975, more names of individual sufferers were mentioned than ever before. In honor of Marchenko, US Ambassador Zimmermann and other NATO delegates observed a moment of silence during a plenary address, resulting in the Soviet and Bulgarian delegations leaving the meeting. In reference to Marchenko's death, Western and like-minded delegations made clear that there must be significant improvement in the human rights practices of the Eastern countries, above all the Soviet Union, for the Vienna meeting to be considered a success and for the possibility of making progress in the Helsinki Process. 161

Perhaps to lessen criticism of Marchenko's death, the week afterwards Soviet leader Gorbachev telephoned Nobel Peace Prize Laureate Andrei Sakharov on December 17, to tell him his seven-year banishment in Gorky had ended, and he and his wife were free to return to Moscow.

In commencing the review of Principles, Luxembourg set the Western tone by observing that "the development of Principle VII (human rights and freedoms) would be the key to success of the Conference." 162 As the NATO allies pressed the Eastern countries on human rights violations, particularly the Soviet Union and Czechoslovakia, Soviet human rights performance was improving. Beyond the General Secretary's personal role in allowing the Sakharovs to retum to Moscow, Soviet human rights activists re- 


\section{THE HELSINKI PROCESS}

norted that sensitive material was being published, in the Moscow Newis for example, that would have doomed its authors to persecution on political charges earlier. Gorbachev's campaign for "openness" in Soviet society, which had begun to take hold by this time, permitted Soviet citizens to express their views and criticize their government within broader limits. Reflecting this change, the Soviet press printed more articles critical of various aspects of Soviet society and politics, as well as foreign articles and opinions.

New decrees on the release of political prisoners and new emigration rules, marking further progress in Soviet human rights policy, were subsequently published January 1, 1987. With new emphasis on openness, the Soviets downplayed in human rights discussions their noninterference argument and responded by accusing their most vocal critics of alleged abuses in their own countries. The United States, United Kingdom, and Canada were thus subjected to lengthy speeches about racism and insensitivity to the plight of the poor. Moreover, the United States was again singled out for criticism for setting itself "in opposition to all the other CSCE participating states" by not ratifying the UN International Covenants on Human Rights. ${ }^{163}$ (The Soviets sometimes get their facts wrong: in this instance, six Helsinki states besides the United States, including Switzerland and Ireland, had not yet ratified the UN Covenants on Human Rights.)

The military security review was least controversial of all, for delegates agreed the implementation of confidence-building measures had improved since 
Madrid and the recently signed Stockholm accords enhanced prospects for even better compliance.

The economic review was business-like and objective, with nine sessions on trade, four on industrial cooperation, five on cooperation in science and technology, and four on environmental cooperation. Western countries both endorsed modest improvements in performance on trade and faulted continuing Eastern inadequacies with respect to business contacts and facilities, lack of accurate economic and commercial information, and difficulties created by countertrade practices that require Western firms selling a product to accept other products as partial or total payment. Eastern performance on trade had been uneven. Contacts between Western seller firms and Eastern end-user enterprises were much worse in the Soviet Union and Romania than in Poland and Hungary, for example, and the frequency and degree of countertrade demands were greater in Czechoslovakia and Romania than in Hungary and the USSR.

In defending their record on trade, Eastern delegations denied there was a lack of information on their economies or of contacts with end-users of Westem products. The Soviets cited, for example, new subsections of economic indicators in their statistical yearbook "The National Economy of the USSR" and quarterly statistics on the volume and geography of foreign trade in their magazine "Foreign Trade." They claimed meetings of bilateral economic councils-consisting of trade officials from an Eastern country and business representatives from a Western country-permitted extensive contacts and exchange of information. And they attacked the West for imposing export con- 


\section{THE HELSINKI PROCESS}

trols and sanctions, denying most-favored-nation trade status under the US Jackson-Vanik amendment (officially known as the Freedom of Emigration Amendment to the Trade Reform Act of 1974), and access to official credit facilities, as well as placing quantitative restrictions on imports. These attacks were relatively restrained, however, reflecting an apparent desire not to undermine their new trade proposals. 164

With respect to industrial cooperation, the West raised such issues as the protection of property rights and the repatriation of profits, but also commented favorably on Eastern legislative initiatives to improve the legal framework for joint ventures. The Soviet delegation spoke in detail on the new law permitting joint ventures with Western firms on Soviet territory. Two specialists from Prague joined the Czechoslovak delegation to explain the conditions of Western participation in joint ventures in Czechoslovakia, which have been permitted only since 1985.165

The review of cooperation in science and technology focused mostly on recent bilateral and multilateral developments following a decline in East-West scientific cooperation after the Soviet invasion of Afghanistan and the declaration of martial law in Poland. The Soviet Union boasted of signing more than 70 intergovernmental science and technology agreements under the Helsinki accords and receiving 30,000 representatives of science, technology, and industry from the West every year for the past five years. 166

New agreements signed with the United States after the Rekykjavik summit raised US-Soviet scientific and technological cooperation to its highest level ever. The review revealed that US scientists have observed 
less interference with their visits in the Soviet Union, and Soviet scientists have received their passports for travel to the United States without significant difficulty. The United States cautioned, however, that govemments can "create all the agreements they want, but they cannot reap the full benefits of scientific interaction if they do not first guarantee freedom to their scientists." 167

The right of individual scientists to pursue their interests freely is an indispensable element of scientific cooperation, yet this right is not broadly observed in the East. In 1982, more than 8,000 scientists in over 40 countries signed a petition to suspend further scientific contact with their scientific colleagues in the USSR to protest the treatment of Sakharov and other Soviet scientists. Oncologist Joseph Irlin, physicist Edward Nadgomiy, and mathematician Mark Freidlin had applied to travel to Israel. Not content to refuse their applications, the Soviet Union fired them from their jobs, cut off their contact with foreign colleagues, and finally accused them of treason. After the Vienna meeting commenced, one of them-Irlin-inexplicably received permission to leave with his family. On another aspect of scientific freedom, Western delegations stressed the need for increased interaction among scientists independent of government control, not as in one Eastern state where meetings between university professors and visiting foreigners are held only in specially prepared rooms.

The increased importance attached to cooperation in environmental protection was very evident when the working group turned to this topic. Many delegations cited favorably the work of the International 


\section{THE HELSINKI PROCESS}

Atomic Energy Agency on nuclear safety following the nuclear accident at Chernobyl in April 1986. While delegates praised efforts to lower emissions of sulfur dioxide, nitrogen oxide, and chlorofluorocarbons, many of them-the Federal Republic of Germany, Switzerland and Austria, in particular-expressed concern over the continuing degradation of their forests from transboundary air pollution. Many Eastern delegations claimed they have taken significant steps to lower pollution levels but argued unsuccessfully to place part of the burden for cleaning up the environment in Eastern Europe on the West. The Soviet delegation attempted to divide the United States and Canada on the acid rain issue and claimed continued US nuclear testing posed a significant danger to the environment. 168

The tone and substance of the reviews of culture and human contacts closely followed the exchanges at Budapest and Bern. The United States, United Kingdom and Canada recalled the fate of the Jazz Section of the Musicians' Union in Czechoslovakia, as well as threats to minority cultures, in particular the Turks in Bulgaria and non-Russian nationalities and Jews in the USSR. The West also highlighted cases of individual writers and artists persecuted or imprisoned by Eastern governments for exercising their rights to freedom of artistic expression. Eastern countries maintained their earlier stance that increased cultural exchange on the basis of government-to-government agreements and a European "culture of peace" would resolve outstanding issues. 169

Whenever the United States has criticized Soviet emigration restrictions, Soviet delegates invariably have 
brought up the US McCarran-Walter Act of 1952, arguing it impermissibly discriminates against Communist nations by selectively excluding US entry to visitors, in violation of the Helsinki accords. Soviet delegates have condemned this legal relic of McCarthyism for producing in the United States "lists of many thousands of names of those who are banned from entering the country for political reasons." The lists include such authors, journalists, and politicians as two Latin American Nobel literary laureates, a former NATO general, an Italian playwright, a Philippine priest, a Canadian author, and the widow of the former president of Chile. Helsinki Commission Chairman Steny Hoyer has called the law "an affront to free speech at home and an embarrassment abroad," but to the regret of the Commission and US delegation at Vienna, it remained on the books at that time. ${ }^{170}$ The 1990 US immigration law removed the McCarthy era restrictions.

In the sessions devoted to information, the Western and neutral countries pointed to continuing Eastern problems of censorship, both internal repression of unofficial publications (samizdat) and restrictions on the flow and accessibility of information from abroad. In the wake of the Daniloff affair, the United States critically described working conditions for journalists in the East. (Nicholas Daniloff was a US News and World Report correspondent arrested in Moscow August 30, 1986, on charges of spying.) The United Kingdom led Western criticism of Eastern jamming. Shrugging off such criticism, the East, and particularly the USSR, engaged in lofty rhetoric about applying breakthroughs in communications technology to the cause 


\section{THE HELSINKI PROCESS}

of peace, citing as an example the increasing use of simultaneous satellite broadcasts ("space bridges") to promote citizen-to-citizen contacts. Eastern delegates also offered reams of numbing statistics to "prove" they took the lead in book publishing and translation of foreign works. ${ }^{171}$

On education, the following six subjects were of primary interest to the West: the importance of freedom of thought and inquiry, the imbalances in EastWest educational exchanges caused by restrictive Eastem exit policies, the capricious last-minute substitution by Eastern governments of uninvited and unqualified persons to attend events in the West, the problems of access to information encountered by Western students and scholars who attempt to conduct academic research in Eastern countries, the persecution of unofficial Hebrew teachers and discrimination against Jews in higher education in the USSR, and the diminishing opportunities for minorities to study in their native language in Romania. In turn, the East criticized the United States for widespread illiteracy, inculcating antiCommunist fears in children through biased teaching, the banning of books by school boards, and inadequate foreign language training. 172

\section{Media Diplomacy}

More than 1,100 accredited journalists covering events in Vienna found the Western states determined to hold the East accountable for noncompliance with its Helsinki human rights commitments. Most observers would agree that human rights stole the political show at the opening sessions. Perhaps the most notable development for journalists, though, was the Soviet dele- 
gation's new attitude of openness towards human rights concerns, not only a reflection of Secretary Gorbachev's glasnost policy, but also a recognition that human rights issues damage Soviet credibility. In previous conferences, the Soviet Union met charges of human rights violations with silence, counterattack, or defensiveness. This style changed in Vienna, where the Soviets conducted what the international edition of Time (November 17, 1986) characterized as "a public relations blitz aimed at defusing this sensitive issue." The Soviet delegation displayed an unprecedented willingness to meet with Western government officials, leaders of nongovernmental organizations, of which there were many, as in Madrid, and even private individuals, to discuss a variety of human rights concerns, especially questions involving divided families and separated spouses.

While not overlooking human rights issues, Western European press coverage emphasized Europe's broader stake in the Helsinki Process. On November 8, for example, Germany's Stuttgarter Zeitung reported "the Helsinki Final Act has proved a kind of constitution governing the whole range of European efforts to step up cooperation."

The Soviet and East European press viewed the Vienna conference quite differently from the West, suggesting that human rights concerns were part of a larger scheme to divert attention from military and economic matters affecting Europe. Pravda commented on November 4, for example, that the United States "is trying to divert close public scrutiny" from Reykjavik and other security affairs "by expatiating with equal persistence and hypocrisy about human rights." 


\section{THE HELSINKI PROCESS}

Conversely, the Soviet press praised the Soviet Union as the proponent for "pan-European" issues and true balance in the Helsinki Process.

\section{More Proposals}

Under the agenda adopted at the preparatory meeting, new proposals could not be considered until the final week of the implementation review, although technically they could be introduced at any time. During the opening week the East came forward with an array of major initiatives for post-Vienna meetings in all three baskets. The Polish delegation proposed new security meetings, the Czechoslovak delegation tabled a proposal for an economic conference in Prague, and the Soviets, taking most delegates by surprise, introduced an initiative for a human rights conference in Moscow. Recognizing that new proposals tended in the past to distract attention from the review phase, many NATO and neutral countries refrained from advancing their ideas for new initiatives until after the Christmas break.

In plenary session December 8, Polish Deputy Minister of Foreign Affairs, Jan Kinast, introduced Poland's proposal for expanding the mandate of the Conference on Confidence- and Security-Building Measures and Disarmament in Europe (CDE). The proposal provided a framework for a second stage of security negotiations, as envisaged in the Madrid Concluding Document, to extend the confidence- and securitybuilding measures agreed at Stockholm and to initiate discussions on reducing armed forces and conventional armaments in an area from the Atlantic to the Urals. Poland's ideas for elaborating the Stockholm measures 
were to limit the scope of military exercises, add notification of independent exercises by air and naval forces, and expand the zone of the measures to include the territories of all Helsinki countries, i.e., the United States and Canada. 173

The inclusion of conventional force reduction talks within the Helsinki Process was the most controversial aspect of Poland's proposal for the West. Reacting swiftly during the closing days of the first Vienna session, NATO foreign ministers issued a declaration in Brussels on December 12 responding to the Polish proposal. The Brussels declaration called for negotiations to build upon and expand the results of the Stockholm Conference within the CSCE and for "distinct" bloc-to-bloc negotiations to prepare a mandate for conventional force reduction talks, much to the concern of the neutral and nonaligned states. 174

Three new Basket II proposals were tabled in the first phase: Czechoslovakia introduced a proposal to convene an economic forum in Prague, Bulgaria proposed an ecological forum, and Austria aimed at decreasing air pollution and arresting the decay of forests.

Delegates advanced a number of human dimension proposals as well. Denmark suggested a post-Vienna human dimension conference. The Netherlands advanced the idea of establishing a consultative commission on human rights. The Federal Republic of Germany proposed the establishment of cultural institutes and other cooperative cultural endeavors in the Helsinki states. Austria and Switzerland jointly tabled a proposal to facilitate freer movement and contacts. Yugoslavia promoted a theatrical seminar and an archi- 


\section{THE HELSINKI PROCESS}

tectural symposium. Austria joined Poland in formally proposing a symposium on cultural heritage.

By far, the most controversial proposal introduced before the Christmas recess began December 20 was the Soviet one reflecting their "new political thinking" for a conference on humanitarian cooperation in Moscow. The high political importance the Soviet Govemment attached to this proposal became evident when it was first announced by Foreign Minister Shevardnadze in his opening speech and later, when Vice Minister Kovalev, who headed the Soviet delegation at Madrid, flew in from Moscow to introduce the proposal formally in plenary on December 10, International Human Rights Day. ${ }^{175}$

As explained by the Soviets, the conference "would initiate a comprehensive discussion geared to a practical result, help reach mutual understanding and improve the state of affairs in the humanitarian area in all countries participating in the European process." To be held at "political level," its plenary sessions would be "open to representatives of the mass media and the public." Its purpose would be to "consider questions of cooperation in promoting the effective implementation of the entire range of rights and freedoms of the individual, as well as cooperation in the sphere of information, culture and education, and contacts between people, agencies and organizations." 176

Western and neutral countries refrained from rejecting the Soviet proposal, but voiced grave reservations about it. US Ambassador Zimmermann stated the US decision whether to agree to the Moscow conference or any other CSCE meeting-and particularly one concerning human rights-would depend on the 
overall performance of the proposed host country. Conditions under which the meeting could be held should equal those at Madrid: guaranteed unimpeded access to the country, the meeting site, and the public by foreign press and nongovernmental visitors. 177

\section{Still More Proposals}

Demonstrating broadening interest and participation in the Helsinki Process, member states tabled more proposals when the meeting reconvened in January, bringing the total to more than 140 before the Easter recess, nearly double the number at Madrid. The leader of the UK delegation, Laurence O'Keeffe, divided them into two groups: "those committing governments to measurable and verifiable action or restraint from action, which the individual citizen can feel in his daily life," and "grand, but vague, declarations admittedly of impeccable intent," 178 presumably in reference to such Eastern proposals as "The Historical Responsibility of Persons Engaged in Cultural and Artistic Activities for the Fate of Peace and Progress and Their Contribution to the Strengthening of Mutual Understanding and Mutual Respect Among Peoples and to the Development of a Peace-Loving Way of Thinking and Acting," known to delegates as WT 77.

Not all Eastern proposals were "declaratory, superfluous and banal," however. Soviet Ambassador Yuri Kashlev clearly stated the Soviet Union view that strengthening security and real disarmament are the central elements of the Helsinki Process. He reiterated the Eastern desire to lower the level of military confrontation in Europe, reduce the risk of sudden attack, strengthen military and strategic stability, and 


\section{THE HELSINKI PROCESS}

increase confidence. Toward this end, Kashlev proposed a single mutual reduction on the order of $100,000-150,000$ troops on each side over a span from one to two years. He repeated Soviet support for the Polish proposal (WT 1) and stressed the right of all participating states, including neutral and nonaligned countries, to play an active role in conventional force negotiations. He criticized the United States and other Western countries for placing security issues on the "back burner." 179

Although the West was unprepared to table its own security proposal in early 1987, Eastern countries introduced even more of them, ranging from nuclear testing, allegations of violations of Salt II, nuclear free zones, and dangers of the US strategic defense initiative to charges the United States was undermining the Anti-Ballistic Missile treaty. In another surprise move, on February 27, the Soviet Union proposed to convene a meeting of experts "to examine the implementa- tion ... of measures against terrorism, including terrorism in international relations."

On human rights principles, the East sponsored a proposal which reiterated the "interrelationship" and "indivisibility" of all Final Act "Principles," equating civil and political with economic and social rights. In rejecting this proposal, the United States said that "civil and political rights are fundamental and inalienable. They represent individual rights which our governments cannot provide." Western human rights proposals in Basket I dealt with religious liberty, the rights of minorities, Helsinki monitoring and membership in independent groups, persons in confinement, and freedom of movement. By contrast, Eastern pro- 
posals addressed such social and economic rights as the right to work and the end of unemployment, the problems of the homeless, and freedom from illiteracy and hunger. 180

In discussing the rights of minorities, a longstanding dispute erupted between Hungary and Romania. To protest Romania's treatment of their Hungarian minority, the Hungarian delegation cosponsored a strongly worded Canadian proposal on minority rights, the first time in Helsinki history an Eastern country has "crossed-over" to cosponsor a major Western human rights proposal. 181

Over 45 proposals were submitted on economic topics. Western ones stressed such areas of continued concern as the lack of business contacts and economic and commercial information in Eastern Europe and the Soviet Union, countertrade, commercial arbitration, and a proposal of the European Community for a conference on economic cooperation in Bonn, to give industrial cooperation between Western and Eastern states what Federal Republic of Germany Ambassador Ekkehard Eickhoff called "a fresh impulse." 182 This initiative matched the Eastern proposal for an economic forum in Prague.

In the field of science and technology, the main Western proposal called for more direct contacts between scientists from different states as well as greater respect for their rights. Others promoted the establishment of safeguards in the field of biotechnology (with Hungary), and advocated a scientific forum in Erice, Italy. An environmental proposal cosponsored by Norway, Switzerland and the USSR made practical and responsible suggestions for monitoring and evaluating 
THE HELSINKI PROCESS

long-range transboundary air pollution. Other such proposals dealt with air and water poliution, consequences of industrial accidents, transboundary movement of hazardous wastes, management of natural resources and, in the wake of Chernobyl, nuclear safety. Initiatives were also introduced on migrant labor in Europe and the promotion of tourism.

Many Eastern economic proposals called for eliminating controls on the transfer of technology, even going so far as to seek Western commitments to promote such transfer actively. 183 Others encouraged industrial cooperation between small- and medium-sized enterprises, international cooperation in the field of marketing, mutual recognition of national standards, and elimination of such obstacles to trade as embargoes, boycotts, and technological blockades.

Drawing on experience of the Ottawa, Budapest, and Bern meetings and the first session at Vienna, the 17 Western countries submitted an important group of 16 proposals constituting the core of the Western approach to human rights and humanitarian issues. 184 US Ambassador Zimmermann called them "critical to the preservation and development of CSCE as a force for genuine security and cooperation." Significant proposals were

- On fundamental freedoms, to require nondiscrimination on the basis of religion; to assure freedom to receive religious education, and to receive, obtain, and use needed religious materials and publications;

- On national minorities, to ensure that persons belonging to national minorities are not victims of 
discrimination and to protect the unique identity of such groups;

- On contributions of individuals and groups, to remove obstacles to monitoring implementation of the Helsinki Process, investigating alleged violations, and expressing views on CSCE matters;

- On persons in confinement, to prohibit torture, psychiatric abuse, arbitrary arrest, detention or exile and to provide maximum access by relatives, friends, and others as well as increased access to legal proceedings;

- On freedom of movement, to abolish exit visa and other procedural impediments to the right to leave one's own country and return to it;

- On human contacts, to improve the treatment of dual nationals, eliminate obstacles to settlement in the country of choice, allow families to travel together if they wish, and end the widespread Eastern practice of denying exit permission to family members because of a relative's actions;

- On postal and telegraphic communications (joined by Austria and Switzerland), to respect the privacy and integrity of such communications;

- On information, to broaden access to information; remove all obstacles to seeking, receiving, and imparting information, including jamming; prevent punitive measures against citizens for gathering, possessing, or distributing information; protect citizens in exercising their rights to know and to express themselves freely by ensuring that classified information is designated as such; help journalists pursue their legitimate professional interests without interference; and mandate 


\section{THE HELSINKI PROCESS}

a followup information forum to discuss these and related issues; and

- On culture and education, to facilitate greater freedom of creation, dissemination, and cooperation and of contacts in the arts, academia, and sciences.

Another key Western proposal on the human dimension, known to delegates as WT 19, called for a series of "new, concrete, precise and intensive efforts" leading to a "Conference on the Human Dimension" before the next Helsinki review meeting. This initiative responded to the Soviet proposal for a Moscow human rights meeting, the East's primary humanitarian initiative.

A novel Austro-Swiss proposal on human contacts required the resolution of all outstanding exit cases before the end of September 1987, a reasonable deadline at the time but one unhonored by the East. An all-out Eastern bid to equate the fundamental right to leave one's country with a purported "right to enter" was firmly rebuffed by the neutrals and the West. 185

Most Eastern proposals in the information area rationalize state control over information flow, justifying jamming, censorship, and restrictions on foreign journalists. ${ }^{186}$ A few, however, contained forward-looking elements to exploit new technologies in the mass communications field and encourage cooperation in several areas, including the exchange of media specialists. By far the largest number of third basket proposals concerned culture and education, many with Eastern and neutral sponsorship and at least one, Poland's proposal for a cultural heritage seminar in Cracow, with sponsorship from all sides. The mixed sponsorship of 
proposals, more prevalent at Vienna than ever before, could be interpreted as another sign of lessening tensions in Europe and increasing acceptance of the Helsinki Process.

\section{Glasnost and Perestroika}

In the spring of 1987, while the United States tried to resolve its differences with France over the Brussels declaration of the previous December, the Soviets earnestly attempted to convince the delegates at Vienna, through plenary speeches and other means available, that the "changes underway in Soviet society are of a fundamental nature." In the 1960s Soviet dissidents adopted "glasnost" as a slogan in their struggle for civil rights. There is little chance that General Secretary Gorbachev was unaware of the symbolic message the new official Soviet policy "glasnost" would send to his countrymen. Soviet First Deputy Foreign Minister Kovalev described the new moral atmosphere taking shape in the country and society as one of "openness, candidness," a new "attitude toward shortcomings, and the desire to work better." The words used to communicate these changes were "restructuring," and the means of implementing it-" "democratization." 187

These twin goals of "restructuring" and "democratization" produced a number of new Soviet laws bearing on the Helsinki Process. To mention several, the "Law on the Nation-Wide Discussion of Important Issues of State Life" would allow national debate of draft legislation concerning the "political, economic, and social development of the country and the exercise of constitutional rights, freedom, and duties of Soviet 
THE HELSINKI PROCESS

citizens." The "Law on the Procedure for Appealing in Court the Unlawful Actions of Officials," somewhat of a surprise to the West, would give Soviet citizens commencing in January 1988, the right to present their grievances to a court of law if they believed their rights had been infringed upon by an official's action. Courts would consider each case within ten days, and measures taken pursuant to the courts' ruling on the complaint would be reported to the court and the complainant.

Soviet Ambassador Kashlev explained how the new "Law of State Enterprises" would contribute to the expansion of industrial cooperation with foreign firms. ${ }^{188}$ This measure decentralized industrial planning and allowed single firms for the first time to schedule the production of their products based on actual public demand, a practice taken for granted in the West. The new economic autonomy of these enterprises would give many of them direct access to foreign markets and opportunities for joint commercial ventures. One Soviet aim in enacting the law was to increase the purchasing power of the ruble and gradually to make it convertible. While such new laws would seem to move Soviet society toward Helsinki goals, many Western delegates remained unconvinced. They expressed positive interest in the "perestroika" of Soviet society, but wished to see more evidence of "glasnost" at Vienna.

\section{Western Security}

The long-awaited Western (NATO) proposal on military security was finally introduced in the third round of the Vienna meeting on July 10, 1987. Based on 
the Brussels declaration seven months earlier, the proposal, known to delegates as WT 129, was designed to respond to Poland's security proposal, which, as mentioned previously, had two main objectives: (1) another round of negotiations on CSBMs to followup the successful Stockholm meeting and (2) initiation of negotiations on conventional disarmament, all within the Helsinki Process. The Western response to this proposal was delayed primarily because of US and French differences over the connection between the disarmament negotiations and the Helsinki Process, the French arguing the negotiations should be directly a part of the Process, and the United States insisting they be independent.

The issue was resolved by the agreement that the disarmament negotiations should be "in the context of the CSCE," but should remain autonomous. The conventional stability talks, as they were designated, would commence following agreement at the Vienna conference and would replace the unproductive MBFR negotiations between the Warsaw Pact and NATO, which began in Vienna in October 1973.

Calling it "the capstone in the Western edifice of proposals," US Ambassador Zimmermann explained to the plenary on July 31 his belief the Western proposal responded fully to the emphasis of the foreign ministers of the neutral and nonaligned countries for "a structure which will allow all participating states to safeguard their national security interests." With respect to the autonomous talks between the Warsaw Pact and NATO, provisions were included to ensure that the 12 CSCE states not participating in this negotiation would have access to information and would 
THE HELSINKI PROCESS

be able to express their views. The key point was "the participants in the conventional stability negotiation will arrange for meetings with the other CSCE participating states periodically to exchange views and information." 189

The NATO and Eastern security proposals differed also in respect to the zone of application of CSBMs. Poland's inclusion of the United States and Canada in the zone was rejected by NATO, which proposed the same zone defined in the Stockholm Document. The East's desire to require the notification of independent exercises by air and naval forces, which was rebuffed at Stockholm but incorporated in Poland's proposal, was unanswered by NATO.

As one of the discontented neutral nations feeling snubbed by the West from participating in the disarmament half of the CDE, Sweden introduced its own security proposal (WT 131) on July 31 , the last day of the 1987 summer session. 190 Swedish Ambassador Curt Lidgard reiterated the Swedish view that negotiations on CSBMs and disarmament in Europe "ought to take place between all the CSCE states as foreseen in the Madrid mandate." Challenging the Western view that "the potential of the Madrid Concluding Document for disarmament negotiations between all the 35 participating states will be used at a later stage," the Swedes submitted their proposal to make "this intention more explicit." Not content to be "dependent entirely on second-hand information" and to be able to "judge for ourselves to what extent the negotiations might affeci Swedish interests," the proposal called for the two sets of negotiations to be conducted within the same facility and in parallel nego- 
tiating sessions, so that delegates participating in either of the two negotiations would have access to the formal meetings of both. The proposal also would require the next Helsinki followup meeting to assess progress achieved in the two negotiations, without prejudice to the autonomous nature of the conventional stability negotiations.

Although the Swedish proposal further complicated resolution of the military security issues in Basket I, the differences were conciliable. What was less certain at that point was how long the autonomous negotiations among the 23 states "whose forces bear most immediately upon the essential security relationship in Europe," should continue merely "in the context of the CSCE."' 191

Much earlier Colonel William Bowman, USAF, argued in a 1985 national security affairs monograph that shifting the stalled MBFR negotiations to the CDE would be "in NATO's best interest." He recognized $\mathrm{CDE}$ as a "fresh approach that should genuinely heip stabilize the confrontation between NATO and Warsaw Pact." Even if manpower and armament reductions are worthy goals he reasoned, NATO could not accept a mutual reduction agreement that would further destabilize the confrontation in central Europe, but achieving mutual force reductions through further confidenceand security-building might be an acceptable alternative. 192

NATO objections to having simultaneous CSBM and disarmament negotiations both part of the Helsinki process, following the Madrid mandate, centered on the twin concerns that the CSCE lacked treaty status and the neutral and nonaligned nations lacked forces 


\section{THE HELSINKI PROCESS}

bearing on the negotiations. Yet as the decision was taken on NATO's security proposal, with strong US backing over mainly French objections, the utility of the Helsinki process in dealing with decentralized security interests in Europe resulting from various coalitions of states was already becoming apparent in the United States. At the time, Director of European Security Negotiations in the Office of the US Secretary of Defense John Matheny not only recognized this trend but also acknowledged that although the importance of the CSCE had grown with time and expectations for it were on the rise, full appreciation of its importance at the Pentagon would take time. Such practical results of the Stockholm document as inspection and verification could only gain credibility through positive experience and time.

Less than a year after Stockholm, US concern for the precise size and scope of Soviet military exercises near the city of Minsk from August 25 through September 1, 1987, led to the first on-site inspection under the Stockholm regime. In connection with this 48-hour inspection on Soviet territory, the United States reported the inspection was successful in showing the purpose of the exercise conformed with Soviet notification and in demonstrating the significant and essential contribution which on-site inspection can make to the confidence- and security-building process. The report also welcomed the spirit of cooperation shown by Soviet officers and enlisted men.193 The Soviet Union conducted similar inspections of NATO exercises in Turkey and the Federal Republic of Germany involving US forces ("Iron Forge") in October 1987. 


\section{A Growing Malaise}

As the meeting reconvened again in Vienna in September 1987 for the fourth round of talks, each side defended its own proposals but showed little disposition to begin the process of compromise which could lead to the end of the conference. By late fall, US Ambassador Zimmermann sensed a growing malaise over "continued infidelity to human rights" which could prolong the meeting. ${ }^{194}$ When the conference dragged through winter without another word agreed toward a concluding text since October, he reminded delegates on March 22, 1988, immediately before the Easter recess, of the sources of malaise. 195

Three hundred political prisoners had been released by Soviet authorities, but a similar number were still imprisoned, 13 of them Helsinki monitors. About half of these prisoners of conscience, contrary to highlevel Soviet assertions, were persons jailed for exercising their right to freedom of religion. Emigration levels, particularly for Soviet Jews, had ceased to rise. General Secretary Gorbachev's repeated statements that access to state secrets was the only bar to emigration had not been observed in practice, and adults still required permission of relatives to emigrate.

Few new cases of long-term political imprisonment by authorities in Eastern countries had come to light, but there had been short-term arrests, detentions, interrogations, beatings, fines, confiscation of property, expulsions, and limits on travel:

- In Latvia, Lithuania, and Estonia, a combination of these repressive tactics was used in February to interfere with the commemoration of important national anniversaries. In Moscow and Lenigrad authorities had 


\section{THE HELSINKI PROCESS}

broken up numerous demonstrations on behalf of free emigration and other human rights.

- In the German Democratic Republic, there had been a dramatic and depressing regression in the official approach to those seeking greater human and religious rights within their country.

- In Czechoslovakia, some 20 prominent citizens, including signers of Charter 77 and religious and cultural activists, had been arrested and thus prevented from attending a British Embassy reception, a Prague church service, and a commemoration of Tomas Masaryk, the founder of Czechoslovakia.

- Since a large-scale amnesty of Polish political prisoners in 1986, short-term detention of Solidarity leaders and other political activists had become commonplace.

- Hungarian authorities, in the first arrests of dissidents in 15 years, temporarily detained eight human rights activists to prevent them from participating in an unofficial observance of the Hungarian uprising of 1848.

In an interview in Bonn on his return to the United States for the Easter recess, Ambassador Zimmermann accused the Soviet Union of consistently "stalling and stonewalling" on human rights and humanitarian issues. The spirit of glasnost had not surfaced in the Vienna talks and Soviet negotiators were "as consistently reluctant to move (on human rights) as they were in the Brezhnev era." 196

The continued Soviet stonewalling on human rights seemed paradoxical to Western delegates at the time. Notwithstanding the perpetual battles eroding its credibility on human rights, the Soviet Union steac 
fastly valued the Helsinki process as the foundation for lasting peace in Europe. Even during the crisis at Madrid, when the Soviets could have checkmated the accords by withholding agreement for further meetings, Foreign Minister Gromyko praised the Final Act and the positive outcome of the Madrid meeting as evidence different social systems can reach mutually acceptable accords.

Less than a year earlier, in July 1987, the Soviet Committee for European Security and Cooperation commended the Helsinki Process for allowing confidence among all European states to strengthen, limiting the possibility of Europe returning to a situation where problems were solved with force of arms, and helping to spread and consolidate a business-like approach to the development of relations between the East and West in a common European home. ${ }^{197}$

When Natan Shcharansky, the cofounder with Yuri Orlov of the Moscow Helsinki monitoring group, testified before the Helsinki Commission in 1986, he told the Commissioners and others who had come to hear him, that he would not be in Washington if it were not for the Helsinki Process. When asked by Representative Dante Fascell whether the United States should repudiate the Helsinki accords over continuing Eastern human rights violations, he indicated the important thing at Vienna was not withdrawal, but insistence on fulfillment of the accords and "to make no progress, no progress in any branch before there will be progress in the third basket." 198 That essentially became the US position at Vienna. 
THE HELSINKI PROCESS

\section{A Successful Conclusion}

Returning to Vienna in April 1988, delegates faced the same partial drafts of a concluding document they had left behind the month before. A compromise text submitted by Austria and Switzerland on human rights and humanitarian concerns in the third basket had been crippled with over 200 Soviet amendments. An innovative text on first basket principles by Austria had less Eastern opposition, only because less specific issues were involved, but still enough to veto agreement. The first real encouragement came on May 13, when the neutral and nonaligned nations submitted a comprehensive draft concluding document generally favorable to the West.

Experience at Belgrade and Madrid had shown that neutral and nonaligned compromise documents helped to concentrate attention on a single set of proposals, but not necessarily to resolve final differences quickly. At Belgrade, the neutral and nonaligned draft was the second of five conciliatory efforts before consensus. At Madrid, both the first draft "for negotiation" and the second draft "for agreement" failed, before the Spanish Prime Minister stepped in with the "singular responsibility of the host nation" to find an acceptable solution. The risk of failure seemed even greater at Vienna with so little text in the three baskets already accepted. As Austrian Chancellor Vranitzky suggested in his opening address, the end could come from "exhaustion."

In any case, the United States told its Helsinki partners it would stay in Vienna "as long as required" to secure a result which "goes well beyond the commitments of Helsinki and Madrid and which gives 
equal weight to military security and human rights." 199 Most Western delegates agreed that if the Soviet Union succeeded in breaking the linkage between security and human rights, "it would mean the end of the whole Helsinki process." 200

Compared with Belgrade and Madrid, the first draft concluding document brought a successful conclusion relatively quickly to the Vienna meeting. On his trip to Moscow to meet with Chairman Gorbachev in May 1988, President Reagan stopped at Helsinki to praise the Helsinki accords in Finlandia Hall for setting new standards of conduct in human rights and international security. The brighter outlook for human rights achieved at the Moscow summit changed the mood for the better at Vienna. A more flexible and reasonable approach of the Soviet delegation in line with the Kremlin's new thinking resulted in Soviet delegate Yuri Kashlev announcing on August 5 his government's acceptance of the compromise proposal of the neutral and nonaligned countries. This surprising break in Soviet bloc unanimity clearly exposed the hard line of Romanian leader Nikolai Ceausescu, who adamantly rejected any further strengthening of human rights provisions of the Final Act.

The neutral and nonaligned countries continued their concerted efforts toward consensus through two more draft documents in the fall and into the next year. Essential compromises were reached on such matters as the number of followup meetings, the host countries' responsibilities for access and openness of future meetings, the mandate for the negotiation on conventional military forces, the jamming of foreign 
THE HELSINKI PROCESS

radio broadcasts, and the knowledge of state secrets as a pretext for denial of emigration permits.

As consensus on the concluding document was within grasp in January 1989, a lingering dispute between Greece and Turkey over whether to include a strategic triangle of Turkish territory close to the Syrian border and the controversial port of Mersin (used by Turkey in the invasion of Cyprus) continued to block final agreement on the conventional stability talks. When these two countries were reminded, however, they would share the blame if their dispute unraveled the Vienna agreement, strongly desired by the Reagan administration while still in office, the issue was promptly resolved.

Even more vexing at the final hour was the defection of the Romanian delegation, which issued an interpretative statement on human rights and religious freedom claiming that "Romania assumed no commitment to implement those among the provisions of the concluding document regarding which it has presented observations and reservations that have not been accepted-provisions that it considers inadequate." 201 Representatives of the West, the neutrals and even the East protested the Romanian position. Then surprisingly with Romanian concurrence the third draft of the concluding document of the neutral and nonaligned nations was adopted by consensus on January 15, 1989, even after the Canadian Ambassador quoted CSCE rules of procedure and concluded "all provisions of the document are equally binding on all participating states." 202 (The text is given in appendix D.) The Vienna meeting thus closed after more than two years of intensive debate and negotiation with statements 
by foreign ministers from January 17 to 19 , including that of George Shultz, who delivered his last public statement as US Secretary of State.

For all its disappointments the Vienna meeting was the most successful of the Helsinki review meetings, particularly with respect to military security and human rights. ${ }^{203} \mathrm{~A}$ landmark decision was reached on continuing the productive Stockholm conference on CSBMs and commencing the autonomous negotiation on conventional forces in Europe within the framework of the Helsinki Process, to replace the stalemated multilateral and balanced force reduction talks. Also, significant new agreements were reached on the rights of individuals and the way in which governments must act to respect individual rights. Moreover, unprecedented progress in the implementation of human rights and humanitarian commitments was achieved for the first time ever during the course of the meeting itself, particularly in the Soviet Union.

A great deal of the credit for the positive outcome of the Vienna meeting can be given to the heads of the Austrian and US delegations. Austrian Ambassador Rudolf Torovsky introduced the ambitious 1987 Austro-Swiss comprehensive text, which basically reflected Western human rights and humanitarian objectives, and succeeded in gaining its acceptance for subsequent negotiations in Basket III and the Principles section of Basket I, where such outstanding human rights issues as freedom of movement and religious liberty were being debated. American Ambassador Warren Zimmermann was particularly effective in resisting Eastern attempts to weaken the strong language of this compromise text.204 


\section{THE HELSINKI PROCESS}

Public diplomacy, which has evolved in the Helsinki Process to a higher plateau of effectiveness and service in US diplomacy, also deserves special credit for the promising outcome. The service of US Helsinki Commission Chairmen as vice-chairmen of the US delegation and other Helsinki Commisssioners as members from time to time clearly signalled to other delegations the seriousness of the US Congress with respect to their deliberations. Moreover, the presence of 15 prominent American citizens representing a variety of civic, human rights, and ethnic groups as public members of the US delegation appointed by President Reagan demonstrated the importance the American people have attached to the Helsinki accords and their human rights principles. A large turnout of US, Canadian, and European nongovernmental organizations in Vienna similarly demonstrated the interest and the important role of private individuals in the Helsinki process.

By the time Secretary Shultz signed the final document in January 1989, it contained the most comprehensive human rights commitments ever achieved in the history of East-West negotiations. New ones included respecting the rights of Helsinki monitors, allowing direct and normal reception of foreign radio broadcasts, maintaining the integrity of private postal and telecommunication services, accepting time limits for resolving applications for family reunification and emergency travel, expanding rights of religious practice, preventing and suppressing international terrorism, and creating a promising mechanism for resolving human rights concerns on a continuous basis. 
The substantial progress in military security and human rights overshadowed other important results in Basket II, such as those concerning commercial information, AIDS, nonrenewable energy resources, sulphur emissions, the ozone layer, and the human rights of scientists and environmental activists.

With reference to a resolve and commitment to continuing the CSCE process, the concluding document specified the fourth main followup meeting would convene in Helsinki, commencing March 24, 1992. US efforts to limit the number of specialized post-Vienna meetings, nearly double the number following Madrid, succeeded to the extent of eliminating proposed scientific and economic forums in Prague, but finally ten such meetings to illuminate areas of cooperation, or difficulty, in military security, information, economics, the environment, the Mediterranean, culture, peaceful settlement of disputes, and human rights were accepted in the concluding document. A number of these are highlighted in the next chapter. 


\section{Seven \\ Gaining Momentum}

IN HIS CLOSING ADDRESS AT VIENNA, US Secretary of State George Shultz referred to the successful meeting just concluded as "a new beginning," for its fateful decisions breaking the deadlock on military security negotiations and raising human rights commitments to their highest level ever in Europe.205 In the wake of the meeting, two separate negotiations on military security and two sessions of the Conference on the Human Dimension contributed strongly to the accelerating momentum of the Helsinki Process before the extraordinary Paris Conference of the CSCE states in November 1990.

Meetings on other aspects of Helsinki affairs, including the London Information Forum in May-June 1989, the Sofia Meeting on Protection of the Environment in October-November 1989, the Bonn Conference on Economic Cooperation in Europe in March-April 1990, and the Palma de Mallorca Meeting on the Mediterranean in September-October 1990, all contributed to the momentous proceedings to follow in Paris.

The Sofia meeting was important for its useful discussion of industrial accidents with transboundary effects, management of hazardous chemicals, and transboundary water pollution, the first such deliberations on the subject of environmental protection in the Helsinki Process. Perhaps even more important though, was its role in catalyzing radical political 
change in Bulgaria, including the ouster of hardline leader Todor Zhirkov. Unprecedented public protests on both environmental and human rights issues by the group of Bulgarian environmentalists known as Ecoglasnost during the meeting led eventually to mass public demonstrations and political realignments which toppled the old regime. Although the delegates prepared a concluding document for the meeting, its adoption was vetoed by Romania over objectionable human rights language. The report was subsequently adopted in Vienna on November 5, 1990.206

The Bonn Economic Conference was particularly notable for three reasons: (1) it marked a decisive turning point away from planned economies toward free markets in the countries of Eastern Europe and the Soviet Union, (2) it committed the CSCE states for the first time to the principles of multiparty democracy and the rule of law, and (3) it put real content into Basket II of the Helsinki Process, which had been badly lagging for some time.207 Effective participation by broadly representative members of the business community gave the conference a practical basis for setting these goals: balanced fiscal and monetary policies, free flow of trade and capital, repatriation of profits in convertible currencies, free and competitive market economies, recognition and protection of private and intellectual property rights, and direct contact between customers and suppliers in domestic and international markets. By recognizing the relationship between political pluralism and market economies, the conference raised higher expectations for the Copenhagen meeting that followed within a few months. 208 


\section{Military Security}

One objective of some delegates in ending the Vienna meeting when it did end was to assure no further delay in convening the military security negotiations which both West Germany and the Soviet Union, and other countries, had pressed to get started for some time. The signing of the concluding document thus permitted the further negotiation on confidence- and security-building measures involving the $35 \mathrm{CSCE}$ states and the negotiation on conventional armed forces in Europe involving the 23 member states of NATO and the Warsaw Pact to commence March 9, 1989 in Vienna.

Since Stockholm, considerable experience had been gained by both Warsaw and NATO forces in applying the CSBMs adopted there in inspecting and verifying military activities. The first applications of these measures in an East-West setting were instructive, and the military reaction of both sides after inspecting as many as 20 exercises through the spring of 1989 was generally positive. The valuable lessons learned through these experiences aided Western military observers in evolving further ideas for strengthening and augmenting the excellent results already achieved at the Stockholm conference.

When the opening session of the CSBM talks began, the West was ready with a broad set of proposals for increasing openness and predictability concerning military forces and their activities in Europe. As the head of the US delegation, Ambassador John Maresca, stated in his opening remarks, "We propose that all European states should exchange on an annual basis complete information on what conventional 


\section{THE HELSINKI PROCESS}

forces and armaments they have on the European continent, and where they are deployed ... . we will press for the right to evaluate it directly." 209

The Western proposals, on themes of transparency of military organization and activities, communications, and contacts, included 12 specific measures. By comparison the Eastern proposals were more general. One exception was an Eastern initiative to expand the Stockholm regime to include independent naval and air activities. This proposal was not accepted by the West because it exceeded the scope of the Madrid mandate for the talks.210

Through four sessions in 1989, progress was made in identifying several areas of common interest, including the convening of a military doctrine seminar to give impetus to the negotiations. This novel seminar, which brought together US Chairman of the Joint Chiefs of Staff Colin Powell and his counterparts from other CSCE countries, was held from January 16 to February 5, 1990, in Washington, DC, for expert discussion of the posture, structure, and activities of conventional forces in Europe in relation to military doctrine. Three weeks of useful discussions gave a fresh outlook to the negotiations and encouraged the delegates to hold a second seminar on military doctrine in the fall of 1991 in Vienna.

By summer, continued Soviet insistence on including naval forces and reluctance to accept new provisions for military information exchange sought by the West hampered progress, but not for long. When NATO leaders at the London summit in July 1990 called for the results of the Vienna meeting to be ready for consideration by an extraordinary ineeting 
of CSCE heads of state and government in Paris in November 1990, the pace of negotiations quickened and an expanded CSBM agreement-the Vienna Document of 1990-was completed in time for its endorsement in Paris.

The Vienna document substantially strengthened and expanded the Stockholm document by incorporating the following measures:

-requiring the annual exchange of information on military forces, plans for the deployment of major weapon and equipment systems, and military budgets;

-introducing a mechanism for consultation and cooperation about unusual military activities and for cooperation about hazardous incidents of a military nature;

-employing a CSBM communications network;

- promoting military contacts among the CSCE states at all levels and arranging visits to air bases;

-directing an annual implementation assessment meeting; and

-improving the regime of notification, observation, and inspection of military activities in Europe.211

Meanwhile in Vienna, on the same day delegates opened the CSBM meeting, representatives of 23 NATO and Warsaw Pact countries began negotiations within the Helsinki framework on Conventional Armed Forces in Europe (CFE) from the Atlantic to the Urals. A few days earlier US Secretary of State James Baker reminded other foreign ministers at the Hofburg Palace in Vienna that "current force levels and force struc- 
THE HELSINKI PROCESS

tures in Europe are not engraved in stone. They are the product of history, the results of conflicts. And they can be changed." 212

The initial Western proposals dealt mainly with the significant reductions needed in key military capabilities-the tanks and artillery and armored personnel carriers-and the confidence-building measures needed to reduce the possibility of surprise attack. As the meeting progressed the Eastern bloc acknowledged the substantial imbalance existing between the conventional forces of the two alliances. Recognizing the significance of this admission and the opportunity the talks created for a less militarized Europe, President Bush proposed at the May 1989 NATO summit meeting that the Western proposal be broadened to include reductions in land-based aircraft and helicopters, and major cuts in US and Soviet combat manpower. He also rejected the Soviet five- to six-year timetable for concluding the talks and called on President Gorbachev for an accelerated schedule with agreement within one year.213 A revised NATO proposal incorporating the President's initiative was tabled at the CFE negotiations in July.

As the discussions continued through fall and into the next year, the delegates narrowed their differences. The inclusion of aircraft in the Western proposal was viewed positively by the Soviet Union owing to NATO air superiority. But reaching agreement on mutually acceptable definitions of combat aircraft, as well as tanks and armored personnel carriers, proved to be more contentious than expected. Another stumbling block in the talks was the question of stockpiling war material in Europe. In the event of a conflict, the 
West would be disadvantaged by the need for the trans-Atlantic shipment of military supplies and therefore proposed to store weapons, equipment, and ammunition at selected sites in West Germany. 214

Uncertain progress toward an agreement was aided by the unforeseen call of President Gorbachev in late 1989 for an extraordinary conference of the nations participating in the Helsinki Process to discuss the future of Europe. Not long afterwards Secretary Baker responded to this surprising development and announced the United States would join a CSCE summit in 1990 provided, among other conditions, the CFE treaty was ready for signature.215

More than six months later, CFE representatives were still struggling toward an overall solution. In welcoming the CSCE foreign ministers to a preparatory meeting for the Paris summit in New York on October 1, 1990 the first Helsinki meeting ever on US soilPresident Bush stressed that "rapid progress is critical in the ongoing negotiations of conventional forces in Europe . . . a conventional arms accord is an essential prerequisite to a CSCE summit." He called on the negotiators in Vienna to "redouble their efforts in the weeks ahead" and pledged US cooperation "in every way possible." 216

Their efforts succeeded and the Treaty on Conventional Armed Forces in Europe was signed by representatives of 22 NATO and Warsaw Pact nations (down from 23 after German reunification on October 3) in Paris on November 19, 1990, the opening day of the Paris CSCE summit. The Paris conference welcomed the completion of the CFE treaty for its "important steps towards enhanced stability and security 


\section{THE HELSINKI PROCESS}

in Europe." 217 One such step would be the destruction of tens of thousands of battle tanks, to reduce this category of weapon to an upper limit of 20,000 tanks on each side. The treaty also provided for reduction to upper limits of 30,000 armored combat vehicles, 20,000 artillery pieces, 6800 combat aircraft, and 2000 attack helicopters on each side, as well as a rigorous inspection and verification regime. To continue to build the comerstone of what President Bush called "the new security architecture for Europe," the treaty also provided for continuing the negotiations under the same mandate and seeking to end them before the Helsinki followup meeting. These efforts would explore the possibility of further reductions in conventional forces, including limitations on combat manpower.

\section{The I. u nan Dimension}

To raise the status of human rights and other humanitarian issues within the Helsinki Process to balance an increasing military security emphasis, the decision was taken at Vienna to convene the Conference on the Human Dimension in three separate sessions before the next Helsinki followup meeting: first in Paris, May-June 1989; next in Copenhagen, June 1990; and last in Moscow, September-October 1991. With the Paris meeting following so closely after the successful Vienna meeting, some delegates questioned whether more could be accomplished to further human rights so soon. As it turned out, the meeting was useful in several ways.

As the Vienna meeting ended, "Bulgaria, Czechoslovakia and the German Democratic Republic each 
launched repressive human rights crackdowns which ran directly counter to the commitments they had just agreed to implement." 218 And Romania continued its practice of "systematization," targeting half of its 13,000 villages for destruction. Opening the Paris meeting in the historic Grand Amphitheater of the Sorbonne, French President Francois Mitterand may have had just such circumstances in mind when he told the delegates the time had come "to call rhetoric to account." 219

In Paris, US and other Western representatives condemned the cruel and contemptible behavior of the Bulgarian government in expelling from the country members of their ethnic Turkish minority. Romania was criticized for mistreatment of its Hungarian and German minorities and "systematization"; Czechoslovakia for the imprisonment of Vaclav Havel, who was released just prior to the Paris meeting; and the German Democratic Republic for maintaining the Berlin Wall and its practice of shooting at persons attempting to cross the border. Even if these criticisms had little effect then, the exposure in Paris of these human rights violations served the longer term purpose of reform.

At the same time, US delegation head Ambassador Morris Abram drew unhappy expressions from some Soviet hardliners who accused the United States of violating womens' rights, holding political prisoners, failing to give parity to native Indian languages and Spanish, and tolerating rampant anti-Semitism.

By far the most useful aspect of the Paris meeting was the advancement of strong, ambitious proposals for discussion and further deliberation at Copenhagen. 


\section{THE HELSINKI PROCESS}

The previous month in addressing a gathering in Mainz, West Germany, President Bush suggested that to heal Europe's tragic division ". . . we strengthen and broaden the Helsinki Process to promote free elections and political pluralism in Eastem Europe." 220 This and other worthy proposals at Paris became the centerpiece of the Copenhagen meeting.

An important Austrian proposal cosponsored by the United States and Hungary called for eliminating the invidious requirement for exit visas. The United States supported a British proposal on respect for the rule of law committing the CSCE states to accept such judicial principles as the presumption of innocence until proven guilty and the allowance of all activities not prohibited by law. A novel Swiss proposal would apply the tactic of confidence-building evolved in Stockholm to the judicial process, by exchanging trial observers. Among 36 proposals introduced, Eastem proposals drew relatively little interest.221

Owing to the short interval between the Vienna and Paris meetings, only limited experience had been gained with the human dimension procedure described in the Vienna document authorizing states to raise instances of noncompliance with any other state at any time and committing the other state to respond. The results evident in Paris concerning this new procedure were mixed, and thus its refinement was deferred. Without the basis for real progress and doubtful of Romanian consensus, the representatives ended their four-week meeting without a concluding document, but stood ready to resume in Copenhagen where they had just finished. 
The dramatic interlude between the Paris and Copenhagen meetings witnessed a political transformation in Eastern Europe and the Soviet Union only rarely seen in history. After a tumultuous fall of 1989 and spring of 1990 witnessing the collapse of communism in Eastern Europe and the Soviet Union and razing of the Berlin wall, the delegates gathered in Copenhagen in the Bella International Conference Center on June 5, 1990, ready to advance the Paris negotiations and create a blueprint for a free and democratic Europe. The US delegation was led by veteran international negotiator Ambassador Max Kampelman, who had contributed strongly to advancing the Helsinki Process at Madrid.

At the outset of the meeting Danish foreign minister Uffe Ellemann-Jenson noted certain preparations essential for the extraordinary CSCE meeting in the fall and granted the government of Albania observer status at the meeting. Similar petitions for such status from Latvia, Estonia, and Lithuania were rejected owing to the Soviet position these countries were not independent.222 Continued Soviet intransigence over these states provoked Icelandic Foreign Minister Jon Baldvin Hannibalsson to comment, "There can be no solution to this problem that is compatible with the Helsinki-Vienna process, other than full recognition of the Baltic nations' right to independence." 223

Normally, after the opening sessions of Helsinki meetings, delegates have reviewed the implementation of previous commitments, but Copenhagen was different. The representatives recognized that "implementation had improved to the point where less review was needed," and sensed an historic opportunity to 


\section{THE HELSINKI PROCESS}

build on the preceding Paris and Bonn meetings to achieve a distinguished human rights document.

Determined negotiations among the delegates over a four-week period produced just such a document. Its breakthrough premise was that "pluralistic democracy and the rule of law are essential for ensuring respect for all human rights and fundamental freedoms." This premise was supported with strong provisions broadly covering democracy and the rule of law, free and fair elections, human rights and fundamental freedoms, minority rights, and ways the CSCE could help protect human rights. One of the ten public members of the US delegation, George Washington University Professor of Comparative and International Law Thomas Buergenthal, termed it "a landmark international charter" unmatched "in its political scope and significance" by such other contemporary human rights documents as the Universal Declaration of Human Rights, the International Covenants on Human Rights, or the European Convention of Human Rights.224

Ironically, as previous East-West differences virtually disappeared at Copenhagen, challenging differences within the Atlantic alliance arose in their place. Disagreements over rules of law barred Western consensus on such important matters as judicial review, separation of powers, freedom of information legislation, civilian control of intelligence agencies, and even effective habeas corpus remedies. Ireland insisted on heavily qualifying the language on free elections with a statement reflecting its concem for terrorist activities in Northern Ireland. Other NATO states offered proposals unacceptable to the United States, for constitu- 
tional reasons. In subsequent hearings before the US Helsinki Commission, Professor Buergenthal pointed out that it would be increasingly more difficult to "help the East establish effective democratic institutions" if the United States and its allies could not "agree on what those institutions should be." 225

With the demise of the Warsaw Pact, the dynamics of the meeting changed also to reflect the emerging interest in Helsinki affairs of other coalitions of European states. The well-established European Community, for example, became more assertive on an array of issues, including that of the unresolved participation of its own delegates. A new group of five representative states-Italy of NATO, Czechoslovakia and Hungary of the disintegrating Warsaw Pact, and Austria and Yugoslavia of the neutral and nonaligned bloc, known as Pentagonal-played a constructive role in arranging informal working procedures for the meeting. These and perhaps other coalitions could gain greater prominence in Helsinki affairs in the future.

The internal dynamics of the negotiations were affected also by a distracting struggle between some delegates and their legal advisors. Diplomats following Helsinki practice have set out concise, politically binding statements of principles applicable to many circumstances; lawyers, on the other hand, have treated the documents as draft treaties, setting forth detailed standards specifying every possible eventuality. The dangers $f *$ the latter are to prolong already lengthy negotiativis over myriad details and drown the process in text, obscuring concrete commitments to basic principles, with no evidence greater detail would enhance performance. One delegate in Copenhagen quipped, 


\section{THE HELSINKI PROCESS}

"The fight used to be between the East and the West; now its between all of us (delegates) and all of our lawyers." 226 This is a potentially destructive trend, if allowed to continue.

With both breakthroughs and distractions at Copenhagen, progress was uneven. Time ran out, for example, in dealing thoroughly with the vexing problems of minority rights, both those of individuals and various cultural, ethnic, and national groups. The delegates recognized these problems had intensified dangerously since Paris, and the issue was squarely faced in limited time. The concluding document set forth over ten new commitments on minority rights adapted from detailed proposals of 12 countries, but still the final text remained unclear.227 The vital issues in this complex area of Helsinki affairs were thus deferred for consideration at the Paris summit, which followed.

\section{The Charter of Paris for a New Europe}

With profound changes of his own making taking place throughout Eastern Europe and the Soviet Union in late 1989, President Gorbachev acted decisively to further his faltering democratization efforts at home and contain the changing realities of Europe within the Helsinki Process. With events moving too rapidly for delay until the 1992 followup meeting, he called for a convocation of the nations participating in the Helsinki process to discuss the future of Europe, the first such meeting since the Final Act was signed in 1975. US Helsinki Commission Co-Chairmen Dennis DeConcini and Steny Hoyer at once urged President Bush to respond favorably to President Gorbachev's initiative, and the United States did so.228 In Prague in 
February 1990, Secretary of State Baker in a guarded response announced the United States was "ready to participate in a 35-nation summit," provided progress was made to establish a CSCE commitment to hold periodic and genuine elections, the CFE treaty was completed and ready for signature at the summit, and the agenda was clearly defined to ensure substantive progress in other areas, including economics.229 Other Helsinki partners responded favorably as well.

The forthcoming summit meeting presented a dilemma for the United States: how to strengthen the CSCE politically and institutionally, as some other countries proposed, without weakening the NATO alliance. The CSCE, with much wider support in Europe and the Soviet Union than in the United States, where it was little known, was emerging as a major force in North American, European, and Soviet relations. At the same time, with the collapse of the military threat from Eastern Europe and the Soviet Union, speculation was rising concerning NATO's future role in Europe.

To help shape the CSCE summit outcome, President Bush was among the first of the Helsinki leaders to urge that the CSCE "take on a broader role," including "regular consultations among senior representatives of the CSCE countries" and perhaps new mechanisms to "help mediate and settle disputes in Europe." 230 At its London summit in July, NATO leaders attempted to clarify the complementary CSCENATO relationship and to define the reinforcing role NATO could play in furthering CSCE's development. In a new European architecture NATO would remain 


\section{THE HELSINKI PROCESS}

central to collective security; NATO's six core proposals for the Paris summit offered to:

(1) create a constructive and continuing high-level dialogue during a dynamic time for Europe politically, economically, and militarily;

(2) enable CSCE to plan more systematically for the longer term through fixed-interval followup meetings;

(3) establish a small permanent administrative secretariat to give our stepped-up activities support;

(4) create an elections monitoring office through which established democracies can lend experience and support to those that are just emerging;

(5) enhance CSCE's parliamentary dimension as Central and East European nations are forming representative systems and forms of government; and

(6) establish a conflict prevention center to promote confidence, predictability, and transparency through exchanges of military information and discussions of unusual military activities and to facilitate the conciliation of disputes.231

National delegations forming a preparatory committee for the Paris summit gathered in Vienna through the summer to narrow their differences and reach general agreement through consensus on various proposals. They debated, for example, differences over the structure and operation of a conflict center, proposals for settling disputes, and those for legally binding environmental measures. The greatest concerns for the United States were the extent to which the Helsinki Process should be burdened with institutional bureaucracies and broadened with new mandates for preventing conflicts, settling disputes, and perhaps even creating a military security role. Related concerns were expressed by other states, particularly the United Kingdom, which questioned whether an institutionalized CSCE might under- 
mine NATO. From another influential quarter, former US Helsinki Commission Chairman Fascell adamantly opposed institutionalizing the CSCE with "a headquarters and large secretariat" and centers in different countries. He feared such steps would "crush the breath out of an institution that not only has survived the cold war but contributed greatly to its demise." 232

By fall the preparatory committee had made the essential compromises for a review of their proposed agenda and draft concluding document by the CSCE foreign ministers meeting at US invitation in New York October 1-2, 1990. In addition to presenting formal statements, resolving most remaining summit issues, and spurring CFE negotiators in Vienna to speed their work, the foreign ministe- gave CSCE approval to the reunification of Germany to take place the following day. The foreign ministers of France, Great Britain, the Soviet Union, and the United States also used the occasion to sign the document suspending all remaining four power rights and responsibilities in Germany, effective at the moment of German reunification. Except for final details, mainly concerning the proposed role of the CSCE parliamentary assembly, preparations for the Paris summit were then complete, and the CSCE was ready to take its place along with NATO and the European Community as a pillar of a new Europe.

As President Bush and other leaders and national delegations of the 34 CSCE states gathered in Paris at the Kleber International Center on November 19, 1990, Britain's Margaret Thatcher expressed the prevailing sentiment: "it's clear that we underestimated the long-term effects of the Helsinki Agreements . . . 
a process which some envisaged as perpetuating the division of Europe has actually helped overcome that division." 233 In the little time remaining after the formal addresses, the heads of state and government signed three historic documents: the Treaty on Conventional Armed Forces in Europe; the Joint Declaration of Twenty-Two States, a nonaggression pact of members of NATO and the Warsaw Pact ending the cold war; and the Charter of Paris for a New Europe.

The Charter of Paris, at appendix E, represented a significant step forward in the Helsinki Process. It reaffirmed past commitments and raised "historic expectations," by chartering a broader mandate and supporting institutions. The first of three sections summarized the Helsinki commitments underlying the essential conditions for "A new era of Democracy, Peace and Unity"; the second set out "Guidelines for the future," concerning the human dimension, security, economic cooperation, the environment, culture, migrant workers, the Mediterranean and nongovernmental organizations; and the last set forth decisions on "New structures and institutions of the CSCE Process."

The section "A new era of Democracy, Peace and Unity" presented the legacy of Helsinki pledges as the basis for an ambitious future of "steadfast commitment to democracy based on human rights and fundamental freedoms, prosperity through economic liberty and social justice, and equal security for all our countries." Among its most fateful pledges, the Charter reaffirmed "a firm commitment to the full implementation of all CSCE principles and provisions," including especially the ten guiding principles of the Final Act, which have "lighted our way toward better relations." 
Building on more recent results of the Copenhagen and Bonn meetings, the Charter cited an undertaking "to build, consolidate and strengthen democracy as the only system of government of our nations," and also strengthened the important Western concept of "economic liberty."

Within the second section, the guidelines for security were particularly sensitive for the United States, for they promised "more structured cooperation" among the states on security matters and linkage of the CSBM and CFE negotiations after the Helsinki followup meeting into "new negotiations on disarmament and confidence and security building open to all participating states." Such integrated negotiations were first mentioned in the Madrid document as a logical outcome of the Stockholm conference. At Vienna, they were advocated strongly by the Eastern bloc, many neutral and nonaligned nations and France, but resolutely resisted at that time, mainly by the United States and Great Britain.

Nothing in the Charter guidelines diminished NATO as the primary US link to European security arrangements. But the guidelines promoted the CSCE as the primary link for the Soviet Union, Eastern Europe, and the neutral and nonaligned states to European security, a need for these states which became even more urgent with the collapse of the Warsaw Pact and the reunification of Germany. With Western leaders all agreeing CSCE could not replace NATO, thcir complementary roles would continue.

To deal promptly with unfinished business of the Copenhagen meeting, the guidelines set forth decisions to convene additional expert meetings on national mi- 


\section{THE HELSINKI PROCESS}

norities in Geneva in July 1991 and on strengthening democratic institutions and promoting applications of the rule of law in Oslo in November 1991.

The decisions set forth in the Paris Charter concerning new structures and institutions to achieve "a new quality of political dialogue and cooperation" at all levels have thrust the CSCE into the limelight of European affairs. They reflected, of course, the decisive changes in Central and Eastern Europe and the Soviet Union which prompted them. Some decisions concerned "the intensification of consultations" and others the creation of new institutions to develop "the structures of the CSCE." Among the first, the leaders agreed to meet at each of the followup meetings, which would be held, as a rule, every two years. Ministers of foreign affairs would meet, as a Council, regularly and at least once a year, "to provide the central forum for political consultations within the CSCE process." A Committee of Senior Officials would be appointed to prepare the meetings of the Council and carry out its decisions.

The decisions on new institutions were wide ranging, aimed at facilitating political exchange and implementing a wider Helsinki mandate with new areas of responsibility. A permanent secretariat was established in Prague to support the consultative process, a Conflict Prevention Center in Vienna to assist the Council in reducing the risk of conflict, and an Office for Free Elections in Warsaw to facilitate contacts and disseminate information on elections. The Charter also called for "greater parliamentary involvement in the CSCE . . . through the creation of a CSCE parliamen- 
tary assembly, involving members of parliaments from all participating states."

For a summit meeting celebrating a new era of European political democracy and respect for human rights, one no longer haunted by a cold war and iron curtain, there was little euphoria. The Persian Gulf crisis was of urgent concern, but offstage. Instead, a growing awareness of the threatening problems of minorities and migration muted the tone of the conference. Eastern European leaders warned their Helsinki partners of the dangers of unmet expectations and the perils of a resurgence of bitter ethnic disputes reminiscent of pre-World War I days. Moreover, economic failure in the Soviet Union and the Balkans could unleash a flood of uncontrolled emigration. In bracing for millions of new refugees in Western Europe, Belgian Prime Minister Wilfried Martens asserted the problem of worsening migration is no longer "a risk. It is a certainty." 234

In his message of hope and higher expectations for a new era in Europe, President Bush praised the Paris Charter as the key to putting "principles into practice." 235 The Helsinki Process has now to build on the solid achievement represented by this historic document. 


\section{Eight \\ The CSCE Pillar of Europe}

LONG BEFORE THE PARIS MEETING, the Helsinki Process had begun to unravel Soviet hegemony over Eastern Europe. From the fiery exchanges on human rights at Belgrade, hard-won progress at Madrid and a fateful turning point at Vienna, the steady Western drumbeat of respect for human rights, balanced with other concerns, had a cumulative effect. The higher standards for human rights set through these years were no longer even questioned after Vienna.

The political transformation of Eastern Europe particularly intensified after the Vienna meeting. In Poland, the leaders of Solidarity cited Helsinki commitments as markers for charting their new national course. In Czechoslovakia, former Helsinki monitor and then President, Vaclav Havel, promoted democratic institutions and civil liberties based on guiding principles of the Final Act. In Hungary, the Józef Antall government made genuine progress in reorienting foreign policy and advancing economic reforms. In Romania, the repression of an ethnic Hungarian priest finally ignited the Romanian people against Nikolai Ceausescu.236 In the German Democratic Republic, known as the "last dissenter," the issue of freedom of travel, guaranteed by the Vienna concluding document, accelerated the downfall of Erich Honecker. By the time the children of East Germany began refusing 


\section{THE HELSINKI PROCESS}

their life there and leaving, the end of the repressive Communist government was near.

Even though it had benefitted the lives of most everyone in Eastern Europe and the Soviet Union by 1989, the Helsinki Process alone did not generate the cataclysmic changes in East European leadership and political and economic policies. The impetus for these changes came more directly from Mikhail Gorbachev himself, as a consequence of his disavowal before the Council of Europe in July 1989 of the Brezhnev doctrine of military support for communist regimes. Again on October 25, 1989, he reaffirmed to Finnish President Mauno Koivisto, "The events that are now taking place in the countries of Eastern Europe concern the people and countries of that region ... . we have no right, moral or political, to interfere in events happening there." 237 Long before, the Stcckholm document required that states belonging to the same alliance refrain from the threat or use of force vis-à-vis each other, but President Gorbachev's statements made the point convincingly.

Soviet President Gorbachev's decision to unleash the East European nations may have firmed about the time of his fourth summit meeting with President Reagan in Moscow. In describing this May 1988 meeting during his next weekly radio address, President Reagan referred to the "seeds of freedom and greater trust (that) were sown" and stated his belief "that, in ways we might not be able to guess, those seeds will take root and grow." 238 In any event, not long afterwards, the General Secretary released his hold on the Vienna negotiations and instructed Ambassador Kashlev to accept the neutral and nonaligned draft 
concluding document, which signalled the major turning point of the meeting.

By then, communism was exhausted: the arms race and a long-flawed economic system had impoverished the Soviet people. And the increasing centrifugal force of nationalism was beginning to threaten internal security. Moreover, such Soviet reform policies as glasnost, perestroika, and democratization were either working too poorly or too well to subdue an impending political catastrophe. President Gorbachev had nothing to lose then in turning to the Helsinki Process, as General Secretary Brezhnev had 15 years earlier.

As noted in Chapter 1, General Secretary Brezhnev most likely took a calculated risk in 1975 by agreeing to let the East Europeans turn to the West for their unmet economic and technological needs, within a new CSCE framework. President Gorbachev may have taken a similar risk in letting the East European states go, expecting they would remain loosely linked within a more mature CSCE framework. His unexpected call in November 1989 for an extraordinary CSCE summit meeting, more than any other single event, vindicated the Helsinki Process for both the East and the West.

The praise that the Paris summit brought to the CSCE drew the attention of US Senators concerned with bringing peace to the Middle East. In hearings before the Senate Subcommittee on European Affairs in March 1991, on "Lessons of the Helsinki Process for the New World Order," Ambassador Kampelman was invited to testify on whether the principles and process of the Helsinki Final Act might be applicable 


\section{THE HELSINKI PROCESS}

to other areas of the world, most particularly the Middle East.

Ambassador Kampleman explained "the Helsinki Process is working ... it has been effective in Europe in achieving higher humanitarian standards ... a and it has established a sense of confidence and growing feeling of security among its partners." 239 No state felt threatened by the process because decisions require consensus and consensus requires full discussion and debate. The process emerged from the community of interest that existed only after the agreement on the two Germanys and their borders. Although some witnesses held out hope, Ambassador Kampleman expressed doubt a CSCE-like process could succeed in the Middle East, at least for the time being, because the circumstances there are so different. After decades, the Arab states have refused to recognize the sovereignty of Israel within mutually agreed, secure borders. The US Helsinki Commission explored the applicability of the Helsinki Process to Africa as well.

What factors stand out in the Helsinki Process which have contributed to its evident success?

First, the Helsinki Process revealed the increasing power of public diplomacy. The public nature of the process projected the values of an open society and enhanced its usefulness in resolving sensitive human rights and humanitarian issues. 240 Time after time the pressure of public diplomacy and mass communications combined damaged the credibility and increased the vulnerability of Eastern countries on these issues, to Western benefit. Also, such pressure aided private diplomatic efforts in winning the freedom of such Soviet human rights activists as Yuri Orlov and Natan 
THE CSCE PILLAR OF EUROPE

Shcharansky. Beset by one Helsinki meeting after another of exposure to a steady pounding of Western public and diplomatic criticism on human rights, Eastern states changed their public relations tactics, but they also moved, even if reluctantly, closer to fulfilling their Helsinki human rights commitments.

Second, the Helsinki Process pioneered an innovative confidence- and security-building regime that added a new dimension to European security and offered a model for other areas of European affairs. The limited intent of the Final Act on military security (mainly to steer clear of the MBFR negotiations) has burgeoned into rigorous inspection, verification, and disarmament measures that have reduced the possibility of armed conflict between European states. Looking ahead to the merger of the CSBM and CFE military security negotiations within the CSCE after the Heisinki followup meeting, the Stockholm agreement demonstrated a military security forum of the Helsinki states could be feasible and productive. ${ }^{241}$

Third, the Helsinki Process has set higher standards for human rights and humanitarian interests. As a forum for more or less continuously evaluating human rights practices against a new yardstick, it has encouraged many countries to condemn impermissible conduct and compelled others to adjust to their partners' disapproval. Without Helsinki, national leaders doubtlessly would not have placed the fate of individuals so high on the agenda of East-West relations. Moreover, there would have been less inspiration and rallying ground for the extraordinary groups of individuals-the Helsinki monitors, Solidarity, Charter 77, and 


\section{THE HELSINKI PROCESS}

the Jazz Section-which have given new meaning to the struggle of the oppressed for freedom. ${ }^{242}$

Fourth, the Helsinki Process legitimized the role of the United States in all of human affairs throughout Europe. Although this role might be taken for granted by Americans, owing to effective bilateral ties with many states, it has special significance for the United States. As a non-European country, US interests in Europe previously had legal status only within the North Atlantic Alliance. The Helsinki Final Act legitimized US interests in the rest of Europe as well.243

Fifth, the Helsinki Process evolved as a dynamic, self-correcting process. Not as a finite negotiation, but as an ongoing process, it gained stature and character from its open, yet basketed, framework of guiding principles which allowed great flexibility for progressively balancing competitive national interests and political wills. One of its procedures, decisionmaking by consensus, has advantages and disadvantages which were discussed in Chapter 1. On balance, this procedure has benefitted the Helsinki Process through many difficult times.

After the Paris summit, other aspects of the Helsinki Process were less clear. Putting principles into practice, as President Bush put it, would take years, even decades in some instances. The new commitments assumed at the Vienna, Bonn, Copenhagen, and Paris meetings, especially in respect to human rights, political pluralism, economic liberty and the rule of law, in fact, widened the gap between principles and practice, just when it was beginning to close. If the framers of the Helsinki Final Act were correct, a widening gap between pledges and performance would give im- 
petus to the implementation of commitments already made, but at the risk of continuing consensus.

To strengthen CSCE institutional support for implementation, beyond that already chartered at Paris, NATO leaders meeting in Rome in November 1991, advanced several astute ideas for consideration at Helsinki.244 Their latest proposals would transform the Office for Free Elections in Warsaw into the Office of Democratic Institutions to promote cooperation in respect to human rights, democracy, and the rule of law and would improve the CSCE's capability to prevent conflicts and manage crises, the latter stemming from frustrated and ultimately failed CSCE attempts to end the fratricidal war in Yugoslavia. Following the procedurally correct form, the Mechanism for Unusual Military Activities adopted in Vienna in 1990 and the Emergency Meeting Mechanism developed by CSCE foreign ministers in Berlin in 1991 were both invoked without effect, owing to lack of political will in the neighboring and other affected states.245 Sad to say, the Yugoslav crisis, still inflamed in mid-1992, represents one of the most egregious assaults on human rights in the history of the Helsinki Process. Whether or not NATO's latest initiative can make a difference in strengthening CSCE capabilities to prevent conflicts and manage crises, given the existing consensus against CSCE taking on explicit military security functions, remains to be seen.

The problem of reconciling political wills, whether in crisis situations or not, will tend to grow as the Helsinki states increase in number, bloc loyalties disappear, and economic transition reaches a critical stage. In 1991, Albania and the three Baltic states of Latvia, 
THE HELSINKI PROCESS

Estonia and Lithuania were each admitted to membership, raising the total number of CSCE states to 38 . While these states were accommodated with the eventual acquiescence of the Soviet Union, a bitter test of political wills could recur if the liberated states of Eastern Europe and the former republics of the Soviet Union, possibly through hardship and despair, end up reverting to anti-democratic, racist, or reactionary policies. 246

In looking ahead, some steps already underway in 1991 should discourage political backsliding in the countries of Eastern Europe and the Soviet Union. The positive measures taken by NATO leaders at their London and Rome meetings - to build partnerships for technical and economic cooperation with Europe's new democracies, at their request, through a new North Atlantic Cooperation Council-should help ease the security concerns of these countries and establish more practical relationships. Also, the development with US support of the long-sought European security identity to complement the NATO alliance should serve to quell further ethnic conflicts in Europe, should they recur. 247

Of all the supporting institutions chartered by the CSCE leaders at Paris, "a CSCE parliamentary assembly, involving members of parliaments from all participating states" adds genius for enlarging public diplomacy and stretching the potential of the Helsinki Process into the future. Meeting in Madrid in April 1991, CSCE lawmakers established an independent Parliamentary Assembly and related procedural rules within the framework of the CSCE and scheduled their first meeting at Budapest in July 1992. The creation 
THE CSCE PILLAR OF EUROPE

of this assembly now encourages the first tangible CSCE links with such other influential European bodies as the Council of Europe and the Western Economic Union, which have been missing. At the Madrid meeting, US Representative and former Helsinki Commission Chairman Dante Fascell urged his new European colleagues "to unite our efforts in making the CSCE Parliamentary Assembly an integral and dynamic aspect of the CSCE process." 248

At the Helsinki followup meeting in 1992, more proposals than ever should be introduced, each one designed one way or another to strengthen security and cooperation in Europe. Among them, in addition to those already cited, will be new proposals for converting Eastern defense industries to civilian production and coping with the intensifying problems of minorities and migration that so troubled the delegates at Paris. Others will build on the ambitious Bonn document to give new momentum to increasingly urgent economic and environmental cooperation in Europe. The chances are good this review meeting, like others before it, will keep the Helsinki Process on a steady course to higher levels of support and service.

In 1975, President Ford addressed leaders of East European ethnic groups at the White House before leaving for Helsinki: "If it all fails, Europe will be not worse off than it is now. If even a part of it succeeds, the lot of people in Eastern Europe will be that much better and the cause of freedom will advance that far." 249 To the lasting credit of the framers of the Final Act, the Helsinki Process did not fail, and with steadily increasing influence in European affairs, Europeans and Americans will not let it fail. 


\section{Appendix A \\ The Three Baskets}

\section{Basket I:}

Declaration on Principles Guiding Relations between Participating States

-I. Sovereign equality, respect for the rights inherent in sovereignty

-II. Refraining from the threat or use of force

-III. Inviolability of frontiers

-IV. Territorial integrity of states

-V. Peaceful settlement of disputes

-VI. Non-intervention in internal affairs

-VII. Respect for human rights and fundamental freedoms, including the freedom of thought, conscience, religion or belief

-VIII. Equal rights and self-determination of peoples -IX. Cooperation among states

-X. Fulfillment in good faith of obligations under international law

Document on Confidence-Building Measures and Certain Aspects of Security and Disarmament

- Prior notification of major military maneuvers

- Prior notification of other military maneuvers

-Exchange of observers

-Prior notification of major military movements

-Other confidence-building measures

-Questions relating to disarmament 
THE HELSINKI PROCESS

\section{Basket II:}

Cooperation in the Field of Economics, of Science and Technology and of the Environment

- Commercial Exchanges (Business contacts and facilities, Economic and commercial information, Marketing) -Industrial Cooperation and Projects of Common Interest (Industrial cooperation, Projects of common interest) - Provisions concerning Trade and Industrial Cooperation (Harmonization of standards, Arbitration, Specific bi-lateral arrangements)

-Science and Technology (Possibilities for improving cooperation, Fields of cooperation, Forms and methods of cooperation)

-Environment (Aims of cooperation, Fields of cooperation, Forms and methods of cooperation)

- Cooperation in Other Areas (Development of transport, Promotion of tourism, Economic and social aspects of migrant labor, Training of personnel)

\section{Basket III:}

\section{Cooperation in Humanitarian and Other Fields}

- Human Contacts (Contacts and regular meetings on the basis of family ties, Reunification of families, Marriage between citizens of different states, Travel for personal or professional reasons, Improvement of conditions for tourism on an individual or collective basis, Meetings among young people, Sport, Expansion of contacts)

-Information (Improvement of the circulation of, access to, and exchange of information, Cooperation in the field of information, Improvement of working conditions for journalists)

- Cooperation and Exchanges in the Field of Culture (Extension of relations. Mutual knowledge. Exchanges 
and dissemination, Access, Contacts and cooperation, Fields and forms of cooperation)

- Cooperation and Exchanges in the Field of Education (Extension of relations, Access and exchanges, Science, Foreign languages and civilizations, Teaching methods) 


\section{Appendix B Conference on Security and Cooperation in Europe: Final Act, Helsinki, 1975}

The Conference on Security and Co-operation in Europe, which opened at Helsinki on 3 July 1973 and continued at Geneva from 18 September 1973 to 21 July 1975, was concluded at Helsinki on 1 August 1975 by the High Representatives of Austria, Belgium, Bulgaria, Canada, Cyprus, Czechoslovakia, Denmark, Finland, France, the German Democratic Republic, the Federal Republic of Germany, Greece, the Holy See, Hungary, Iceland, Ireland, Italy, Liechtenstein, Luxembourg, Malta, Monaco, the Netherlands, Norway, Poland, Portugal, Romania, San Marino, Spain, Sweden, Switzerland, Turkey, the Union of Soviet Socialist Republics, the United Kingdom, the United States of America and Yugoslavia.

During the opening and closing stages of the Conference the participants we:e addressed by the SecretaryGeneral of the United Nations as their guest of honour. The Director-General of UNESCO and the Executive Secretary of the United Nations Economic Commission for Europe addressed the Conference during its second stage.

During the meetings of the second stage of the Conference, contributions were received, and statements heard, from the following non-participating Mediterranean States on various agenda items: the Democratic and Popular Republic of Algeria, the Arab Republic of Egypt, Israel, the Kingdom of Morocco, the Syrian Arab Republic, Tunisia. Motivated by the political will, in the interest of peoples, to improve and intensify their relations and to contrib- 


\section{THE HELSINKI PROCESS}

ute in Europe to peace, security, justice and co-operation as well as to rapprochement among themselves and with the other States of the world,

Determined, in consequence, to give full effect to the results of the Conference and to assure, among their States and throughout Europe, the benefits deriving from those results and thus to broaden, deepen and make continuing and lasting the process of détente,

The High Representatives of the participating States have solemnly adopted the following:

\section{QUESTIONS RELATING TO SECURITY IN EUROPE}

The States participating in the Conference on Security and Co-operation in Europe,

Reaffirming their objective of promoting better relations among themselves and ensuring conditions in which their people can live in true and lasting peace free from any threat to or attempt against their security;

Convinced of the need to exert efforts to make détente both a continuing and an increasingly viable and comprehensive process, universal in scope, and that the implementation of the results of the Conference on Security and Co-operation in Europe will be a major contribution to this process;

Considering that solidarity among peoples, as well as the common purpose of the participating States in achieving the aims as set forth by the Conference on Security and Co-operation in Europe, should lead to the development of better and closer relations among them in all fields and thus to overcoming the confrontation stemming from the character of their past relations, and to betier mutual understanding;

Mindful of their common history and recognizing that the existence of elements common to their traditions and values can assist them in developing their relations, and 
desiring to search, fully taking into account the individuality and diversity of their positions and views, for possibilities of joining their efforts with a view to overcoming distrust and increasing confidence, solving the problems that separate them and co-operating in the interest of mankind;

Recognizing the individuality of security in Europe as well as their common interest in the development of cooperation throughout Europe and among themselves and expressing their intention to pursue efforts accordingly;

Recognizing the close link between peace and security in Europe and in the world as a whole and conscious of the need for each of them to make its contribution to the strengthening of world peace and security and to the promotion of fundamental rights, economic and social progress and well-being for all peoples;

Have adopted the following:

1.

(a) Declaration on Principles Guiding Relations between Participating States

The participating States,

Reaffirming their commitment to peace, security and justice and the continuing development of friendly relations and co-operation;

Recognizing that this commitment, which reflects the interest and aspirations of peoples, constitutes for each participating State a present and future responsibility; heightened by experience of the past;

Reaffirming, in conformity with their membership in the United Nations and in accordance with the purposes and principles of the United Nations, their full and active support for the United Nations and for the enhancement of its role and effectiveness in strengthening international peace, security and justice, and in promoting the solution 


\section{THE HELSINKI PROCESS}

of international problems, as well as the development of friendly relations and co-operation among States;

Expressing their common adherence to the principles which are set forth below and are in conformity with the Charter of the United Nations, as well as their common will to act, in the application of these principles, in conformity with the purposes and principles of the Chapter of the United Nations;

Declare their determination to respect and put into practice, each of them in its relations with all other participating States, irrespective of their political, economic or social systems as well as of their size, geographical location or level of economic development, the following principles, which all are of primary significance, guiding their mutual relations:

\section{Sovereign equality, respect for the rights inherent in sovereignty}

The participating States will respect each other's sovereign equality and individually as well as all the rights inherent in and encompassed by its sovereignty, including in particular the right of every State to juridical equality, to territorial integrity and to freedom and political independence. They will also respect each other's right freely to choose and develop its political, social, economic and cultural systems as well as its right to determine its laws and regulations.

Within the framework of international law, all the participating States have equal rights and duties. They will respect each other's right to define and conduct as it wishes its relations with other States in accordance with international law and in the spirit of the present Declaration. They consider that their frontiers can be changed, in accordance with international law, by peaceful means and by agreement. They also have the right to belong or not to 
belong to international organization, to be or not to be a party to bilateral or multilateral treaties including the right to be or not to be a party to treaties of alliance; they also have the right to neutrality.

\section{Refraining from the threat or use of force}

The participating States will refrain in their mutual relations, as well as in their international relations in general, from the threat or use of force against the territorial integrity or political independence of any State, or in any other manner inconsistent with the purposes of the United Nations and with the present Declaration. No consideration may be invoked to serve to warrant resort to the threat or use of force in contravention of this principle.

Accordingly, the participating States will refrain from any acts constituting a threat of force or direct or indirect use of force against another participating State. Likewise they will refrain from any manifestation of force for the purpose of inducing another participating State to renounce the full exercise of its sovereign rights. Likewise they will also refrain in their mutual relations from any act of reprisal by force.

No such threat or use of force will be employed as a means of settling disputes, or questions likely to give rise to disputes, between them.

\section{Inviolability of frontiers}

The participating States regard as inviolable all one another's frontiers as well as the frontiers of all States in Europe and therefore they will refrain now and in the future from assaulting these frontiers. 


\section{THE HELSINKI PROCESS}

Accordingly, they will also refrain from any demand for, or act of, seizure and usurpation of part or all of the territory of any participating State.

\section{Territorial integrity of States}

The participating States will respect the territorial integrity of each of the participating States.

Accordingly, they will refrain from any action inconsistent with the purposes and principles of the Charter of the United Nations against the territorial integrity, political independence or the unity of any participating State, and in particular from any such action constituting a threat or use of force.

The participating States will likewise refrain from making each other's territory the object of military occupation or other direct or indirect measures of force in contravention of international law, or the object of acquisition by means of such measures or the threat of them. No such occupation or acquisition will be recognized as legal.

\section{Peaceful settlement of disputes}

The participating States will settle disputes among them by peaceful means in such a manner as not to endang. international peace and security, and justice.

They will endeavor in good faith and a spirit of cooperation to reach a rapid and equitable solution on the basis of international law.

For this purpose they will use such means as negotiation, enquiry, mediation, conciliation, arbitration, judicial settlement or other peaceful means of their own choice including any settlement procedure agreed to in advance of disputes to which they are parties. 
In the event of failure to reach a solution by any of the above peaceful means, the parties to a dispute will continue to seek a mutually agreed way to settle the dispute peacefully.

Participating States, parties to a dispute among them, as well as cther participating States, will refrain from any action which might aggravate the situation to such a degree as to endanger the maintenance of international peace and security and thereby make a peaceful settlement of the dispute more difficult.

\section{Non-intervention in internal affairs}

The participating States will refrain from any intervention, direct or indirect, individual or collective, in the internal or external affairs falling within the domestic jurisdiction of another participating State, regardless of their mutual relations.

They will accordingly refrain from any form of armed intervention or threat of such intervention against another participating state.

They will likewise in all circumstances refrain from any other act of military, or of political, economic or other coercion designed to subordinate to their own interest the exercise by another participating State of the rights inherent in its sovereignty and thus to secure advantages of any kind.

Accordingly, they will, inter alia, refrain from direct or indirect assistance to terrorist activities, or to subversive or other activities directed towards the violent overthrow of the regime of another participating State. 


\section{THE HELSINKI PROCESS}

\section{Respect for human rights and fundamental freedoms, including the freedom of thought, conscience, religion or belief}

The participating States will respect human rights and fundamental freedoms, including the freedom of thought, conscience, religion or belief, for all without distinction as to race, sex, language or religion.

They will promote and encourage the effective exercise of civil, political, economic, social, cultural and other rights and freedoms all of which derive from the inherent dignity of the human person and are essential for his free and full development.

Within this framework the participating States will recognize and respect the freedom of the individual to profess and practice, alone or in community with others, religion or belief acting in accordance with the dictates of his own conscience.

The participating States on whose territory national minorities exist will respect the right of persons belonging to such minorities to equality before the law, will afford them the full opportunity for the actual enjoyment of human rights and fundamental freedoms and will, in this manner, protect their legitimate interests in this sphere.

The participating States recognize the universal significance of human rights and fundamental freedoms, respect for which is an essential factor for the peace, justice and well-being necessary to ensure the development of friendly relations and co-operation among themselves as among all States.

They will constantly respect these rights and freedoms in their mutual relations and will endeavour jointly and separately, including in cooperation with the United Nations, to promote universal and effective respect for them.

They confirm the right of the individual to know and act upon his rights and duties in this field. 
In the field of human rights and fundamental freedoms, the participating States will act in conformity with the purposes and principles of the Charter of the United Nations and with the Universal Declaration of Human Rights. They will also fulfill their obligations as set forth in the interrational declarations and agreements in this field, including, inter alia, the International Covenants on Human Rights, by which they may be bound.

\section{Equal rights and self-determination of peoples}

The participating States will respect the equal rights of peoples and their right to self-determination. acting at all times in conformity with the purposes and principles of the Charter of the United Nations and with the relevant norms of international law, including those relating to territorial integrity of States.

By virtue of the principle of equal rights and selfdetermination of peoples, all peoples always have the right, in full freedom, to determine, when and as they wish, their internal and external political status, without external interference, and to pursue as they wish their political, economic, social and cultural development.

The participating States reaffirm the universal significance of respect for and effective exercise of equal rights and self-determination of peoples for the development of friendly relations among themselves as among all States; they also recall the importance of the elimination of any form of violation of this principle.

\section{Co-operation among States}

The participating States will develop their co-operation with one another and with all States in all fields in accord- 


\section{THE HELSINKI PROCESS}

ance with the purposes and principles of the Chanter of the United Nations. In developing their co-operation the participating States will place special emphasis on the fields as set forth within the framework of the Conference on Security and Co-operation in Europe, with each of them making its contribution in conditions of full equality.

They will endeavour, in developing their co-operation as equals, to promote mutual understanding and confidence, friendly and good-neighborly relations among themselves, international peace, security and justice. They will equally endeavour, in developing their co-operation, to improve the well-being of peoples and contribute to the fulfillment of their aspirations through, inter alia, the benefits resulting from increased mutual knowledge and from progress and achievement in the economic, scientific, technological, social, cultural and humanitarian field. They will take steps to promote sonditions favorable to making these benefits available to all; they will take into account the interest of all in the narrowing of differences in the levels of economic development, and in particular the interest of developing countries throughout the world.

They confirm that governments, institutions, organizations and persons have a relevant and positive role to play in contributing toward the achievement of these aims of their co-operation.

They will strive, in increasing their co-operation as set forth above, to develop closer relations among themselves on an improved and more enduring basis for the benefit of peoples.

\section{Fulfillment in good faith of obligations under international law}

The participating States will fulfill in good faith their obligations under international law, both those obligations arising from the generally recognized principles and rules 
of international law and those obligations arising from treaties or other agreements, in conformity with international law, to which they are parties.

In exercising their sovereign rights, including the right to determine their laws and regulations, they will conform with their legal obligations under international law; they will furthermore pay due regard to and implement the provisions in the Final Act of the Conference on Security and Co-operation in Europe.

The participating States confirm that in the event of a conflict between the obligations of the members of the United Nations under the Charter of the United Nations and their obligations under any treaty or other international agreement, their obligations under the Charter will prevail, in accordance with Article 103 of the Charter of the United Nations.

All the principles set forth above are of primary significance and, accordingly, they will be equally and unreservedly applied, each of them being interpreted taking into account the others.

The participating States express their determination fully to respect and apply these principles, as set forth in the present Declaration, in all aspects, to their mutual relations and co-operation in order to ensure to each participating State the benefits resulting from the respect and application of these principles by all.

The participating States, paying due regard to the principles above and, in particular, to the first sentence of the tenth principle, "Fulfillment in good faith of obligations under international law", note that the present Declaration does not affect their rights and obligations, nor the corresponding treaties and other agreements and arrangements.

The participating States express the conviction that respect for these principles will encourage the development of normal and friendly relations and the progress of cooperation among them in all fields. They also express the 


\section{THE HELSINKI PROCESS}

conviction that respect for these principles will encourage the development of political contacts among them which in turn would contribute to better mutual understanding of their positions and views.

The participating States declare their intention to conduct their relations with all other States in the spirit of the principles contained in the present Declaration.

\section{(b) Matters related to giving effect to certain of the above Principles}

(i) The participating States,

Reaffirming that they will respect and give effect to refraining from the threat or use of force and convinced of the necessity to make it an effective norm of international life,

Declare that they are resolved to respect and carry out, in their relations with one another, inter alia, the following provisions which are in conformity with the Declaration on Principles Guiding Relations between Participating States.

-To give effect and expression, by all the ways and forms which they consider appropriate, to the duty to refrain from the threat or use of force in their relations with one another.

-To refrain from any use of armed forces inconsistent with the purposes and principles of the Charter of the United Nations and the provisions of the Declaration on Principles Guiding Relations between Participating States, against another participating State, in particular from invasion of or attack on its territory.

-To refrain from any manifestation of force for the purpose of inducing another participating State to renounce the full exercise of its sovereign rights.

-To refrain from any act of economic coercion designed to subordinate to their own interest the exercise by 
another participating State of the rights inherent in its sovereignty and thus to secure advantages of any kind.

- To take effective measures which by their scope and by their nature constitute steps towards the ultimate achievement of general and complete disarmament under strict and effective international control.

-To promote, by all means which each of them considers appropriate, a climate of confidence and respect among peoples consonant with their duty to refrain from propaganda for wars of aggression or for any threat or use of force inconsistent with the purposes of the United Nations and with the Declaration of Principles Guiding Relations between Participating States, against another participating State.

-To make every effort to settle exclusively by peaceful means any dispute between them, the continuance of which is likely to endanger the maintenance of international peace and security in Europe, and to seek, first of all, a solution through the peaceful means set forth in Article 33 of the United Nations Charter.

To refrain from any action which could hinder the peaceful settlement of disputes between the participating States.

(ii) The participating States,

Reaffirming their determination to settle their disputes as set forth in the Principle of Peaceful Settlement of Disputes;

Convinced that the peaceful settlement of disputes is a complement to refraining from the threat or use of force, both being essential though not exclusive factors for the maintenance and consolidation of peace and security;

Desiring to reinforce and to improve the methods at their disposal for the peaceful settlement of dispute;

1. Are resolved to pursue the examination and elaboration of a generally acceptable method for the peaceful 


\section{THE HELSINKI PROCESS}

settlement of disputes aimed at complementing existing methods, and to continue to this end to work upon the "Draft Convention on a European System for the Peaceful Settlement of Disputes" submitted by Switzerland during the second stage of the Conference on Security and Cooperation in Europe, as well as other proposals relating to it and directed towards the elaboration of such a method.

2. Decide that, on the invitation of Switzerland, a meeting of experts of all the participating States will be convoked in order to fulfil the mandate described in paragraph 1 above within the framework and under the procedures of the follow-up to the Conference laid down in the chapter "Follow-up to the Conference".

3. This meeting of experts will take place after the meeting of the representatives appointed by the Ministers of Foreign Affairs of the participating States, scheduled according to the chapter "Follow-up to the Conference" for 1977; the results of the work of this meeting of experts will be submitted to Governments.

2.

Document on confidence-building measures and certain aspects of security and disarmament

The participating States,

Desirous of eliminating the causes of tension that may exist among them and thus of contributing to the strengthening of peace and security in the world;

Determined to strengthen confidence among them and thus to contribute to increasing stability and security in Europe;

Determined further to refrain in their mutual relations, as well as in their international relations in general, from the threat or use of force against the territorial integrity or political independence of any State, or in any other manner inconsistent with the purposes of the United Nations 
and with the Declaration on Principles Guiding Relations between Participating States as adopted in this Final Act;

Recognizing the need to contribute to reducing the dangers of armed conflict and of misunderstanding or miscalculation of military activities which could give rise to apprehension, particularly in a situation where the participating States lack clear and timely information about the nature of such activities;

Taking into account considerations relevant to efforts aimed at lessening tension and promoting disarmament;

Recognizing that the exchange of observers by invitation at military manoeuvres will help to promote contacts and mutual understanding;

Having studied the question of prior notification of major military movements in the context of confidencebuilding;

Recognizing that there are other ways in which individual States can contribute further to their common objectives;

Convinced of the political importance of prior notification of major military manoeuvres for the promotion of mutual understanding and the strengthening of confidence, stability and security;

Accepting the responsibility of each of them to promote these objectives and to implement this measure, in accordance with the accepted criteria and modalities, as essentials for the realization of these objectives;

Recognizing that this measure deriving from political decision rests upon a voluntary basis;

Have adopted the following:

\section{I \\ Prior notification of major military manoeuvres}

They will notify their major military manoeuvres to all other participating States through usual diplomatic channels in accordance with the following provisions: 


\section{THE HELSINKI PROCESS}

Notification will be given of major military manoeuvres exceeding a total of 25,000 troops, independently or combined with any possible air or naval components (in this context the word "troops" includes amphibious and airborne troops). In the case of independent manoeuvres of amphibious or airborne troops, or of combined manoeuvres involving them, these troops will be included in this total. Furthermore, in the case of combined manoeuvres which do not reach the above total but which involve land forces together with significant numbers of either amphibious or airborne troops, or both, notification can also be given.

Notification will be given of major military manoeuvres which take place on the territory, in Europe, of any participating State as well as, if applicable in the adjoining sea area and air space.

In the case of a participating State whose territory extends beyond Europe, prior notification need be given only of manoeuvres which take place in an area within 250 kilometers from its frontier facing or shared with any other European participating State, the participating State need not, however, give notification in cases in which that area is also contiguous to the participating State's frontier facing or shared with a non-European non-participating State.

Notification will be given 21 days or more in advance of the start of the manoeuvre or in the case of a manoeuvre arranged at shorter notice at the earliest possible opportunity prior to its starting date.

Notification will contain information of the designation, if any, the general purpose of and the States involved in the manoeuvre, the type or types and numerical strength of the forces engaged, the area and estimated time-frame of its conduct. The participating States will also, if possible, provide additional relevant information, particularly that related to the components of the forces engaged and the period of involvement of these forces. 


\section{Prior notification of other military manoeuvres}

The participating States recognize that they can contribute further to strengthening confidence and increasing security and stability, and to this end may also notify smallerscale military manoeuvres to other participating States, with special regard for those near the area of such manoeuvres.

To the same end, the participating States also recognize that they may notify other military manoeuvres conducted by them.

\section{Exchange of observers}

The participating States will invite other participating States, voluntarily and on a bilateral basis, in a spirit of reciprocity and goodwill towards all participating States, to send observers to attend military manoeuvres.

The inviting State will determine in each case the number of observers, the procedures and conditions of their participation, and give other information which it may consider useful. It will provide appropriate facilities and hospitality.

The invitation will be given as far ahead as is conveniently possible through usual diplomatic channels.

\section{Prior notification of major military movements}

In accordance with the Final Recommendations of the Helsinki Consultations the participating States studied the question of prior notification of major military movements as a measure to strengthen confidence.

Accordingly, the participating States recognize that they may, at their own discretion and with a view to contributing to confidence-building, notify their major military movements. 


\section{THE HELSINKI PROCESS}

In the same spirit, further consideration will be given by the States participating in the Conference on Security and Co-operation in Europe to the question of prior notification of major military movements, bearing in mind, in particular, the experience gained by the implementation of the measures which are set forth in this document.

\section{Other confidence-building measures}

The participating States recognize that there are other means by which their common objectives can be promoted.

In particular, they will, with due regard to reciprocity and with a view to better mutual understanding, promote exchanges by invitation among their military personnel, including visits by military delegations.

$$
\text { *** }
$$

In order to make a fuller contribution to their common objective of confidence-building, the participating States, when conducting their military activities in the area covered by the provisions for the prior notification of major military manoeuvres, will prior notification of major military manoeuvres, will duly take into account and respect this objective.

They also recognize that the experience gained by the implementation of the provisions set forth above, together with further efforts, could lead to developing and enlarging measures aimed at strengthening confidence.

II

\section{Questions relating to disarmament}

The participating States recognize the interest of all of them in efforts aimed at lessening military confrontation and promoting disarmament which are designed to complement political detente in Europe and to strengthen their 
security. They are convinced of the necessity to take effective measures in these fields which by their scope and by their nature constitute steps towards the ultimate achievement of general and complete disarmament under strict and effective international control, and which should result in strengthening peace and security throughout the world.

\section{III \\ General considerations}

Having considered the views expressed on various subjects related to the strengthening of security in Europe through joint efforts aimed at promoting detente and disarmament, the participating States, when engaged in such efforts, will, in this context, proceed, in particular, from the following essential considerations:

-The complementary nature of the political and military aspects of security;

- The interrelation between the security of each participating State and security in Europe as a whole and the relationship which exists, in the broader context of world security, between security in Europe and security in the Mediterranean area;

-Respect for the security interests of all States participating in the Conference on Security and Co-operation in Europe inherent in their sovereign equality;

-The importance that participants in negotiating fora see to it that information above relevant developments, progress and results is provided on an appropriate basis to other States participating in the conference on Security and Co-operation in Europe and, in return, the justified interest of any of those States in having their views considered. 
THE HELSINKI PROCESS

\section{CO-OPERATION IN THE FIELD OF ECONOMICS, OF SCIENCE AND TECHNOLOGY AND OF THE ENVIRONMENT}

The participating States,

Convinced that their efforts to develop co-operation in the fields of trade, industry, science and technology, the environment and other areas of economic activity contribute to the reinforcement of peace and security in Europe and in the world as a whole,

Recognizing that co-operation in these fields would promote economic and social progress and the improvement of the conditions of life,

Aware of the diversity of their economic and social systems,

Reaffirming their will to intensify such co-operation between one another, irrespective of their systems,

Recognizing that such co-operation, with due regard for the different levels of economic development, can be developed, on the basis of equality and mutual satisfaction of the partners, and of reciprocity permitting, as a whole, an equatable distribution of advantages and obligations of comparable scale, with respect for bilateral and multilateral agreements,

Taking into account the interests of the developing countries throughout the world, including those among the participating countries as long as they are developing from the economic point of view; reaffirming their will to cooperate for the achievement of the aims and objectives established by the appropriate bodies of the United Nations in the pertinent documents concerning development, it being understood that each participating State maintains the positions it has taken on them; giving special attention to the least developed countries, 
THE FINAL ACT

Convinced that the growing world-wide economic interdependence calls for increasing common and effective efforts towards the solution of major world economic problems such as food, energy, commodities, monetary and financial problems, and therefore emphasizes the need for promoting stable and equitable international economic relations, thus contributing to the continuous and diversified economic development of all countries.

Having taken into account the work already undertaken by relevant international organizations and wishing to take advantage of the possibilities offered by these organizations, in particular by the United Nations Economic Commission for Europe, for giving effect to the provisions of the final documents of the conference,

Considering that the guidelines and concrete recommendations contained in the following texts are aimed at promoting further development of their mutual economic relations, and convinced that their co-operation in this field should take place in full respect for the principles guiding relations among participating States as set forth in the relevant document,

Having adopted the following:

\section{Commercial Exchanges}

\section{General provisions}

The participating States,

Conscious of the growing role of international trade as one of the most important factors in economic growth and social progress,

Recognizing that trade represents an essential sector of their co-operation, and bearing in mind that the provisions contained in the above preamble apply in particular to this sector, 


\section{THE HELSINKI PROCESS}

Considering that the volume and structure of trade among the participating States do not in all cases correspond to the possibilities created by the current level of their economic, scientific and technological development,

are resolved to promote, on the basis of the modalities of their economic co-operation, the expansion of their mutual trade in goods and services, and to ensure conditions favourable to such development;

recognize the beneficial effects which can result for the development of trade from the application of most favoured nation treatment;

will encourage the expansion of trade on as broad a multilateral basis as possible, thereby endeavouring to utilize the various economic and commercial possibilities;

recognize the importance of bilateral and multilateral intergovernmental and other agreements for the long-term development of trade;

note the importance of monetary and financial questions for the development of international trade, and will endeavour to deal with them with a view to contributing to the continuous expansion of trade;

will endeavour to reduce or progressively eliminate all kinds of obstacles to the development of trade;

will foster a steady growth of trade while avoiding as far as possible abrupt fluctuations in their trade;

consider that their trade in various products should be conducted in such a way as not to cause or threaten to cause serious injury-and should the situation arise, market disruption-in domestic markets for these products and in particular to the detriment of domestic producers of like or directly competitive products; as regards the concept of market disruption, it is uncerstood that it should not be invoked in a way inconsistent with the relevant provisions of their international agreements; if they resort to safeguard measures, they will do so in conformity with their commitments in this field arising from international agreements 
to which they are parties and will take account of the interests of the parties directly concerned;

will give due attention to measures for the promotion of trade and the diversification of its structure;

note that the growth and diversification of trade would contribute to widening the possibilities of choice of products; consider it appropriate to create favourable conditions for the participation of firms, organizations and enterprises in the development of trade.

\section{Business contacts and facilities}

The partici ating States,

Conscious of the importance of the contribution which an improvement of business contacts, and the accompanying growth of confidence in business relationships, could make to the development of commercial and economic relations,

will take measures further to improve conditions for the expansion of contacts between representatives of official bodies, of the different organizations, enterprises, firms and banks concerned with foreign trade, in particular, where useful, between sellers and users of products and services, for the purpose of studying commercial possibilities, concluding contracts, ensuring their implementation and providing after-sales services;

will encourage organizations, enterprises and firms concerned with foreign trade to take measures to accelerate the conduct of business negotiations;

will further take measures aimed at improving working conditions of representatives of foreign organizations, enterprises, firms and banks concerned with external trade, particularly as follows:

-by providing the necessary information, including information on legislation and procedures relating to the estab- 


\section{THE HELSINKI PROCESS}

lishment and operation of permanent representation by the above mentioned bodies;

-by examining as favourably as possible requests for the establishment of permanent representation and of offices for this purpose, including, where appropriate, the opening of joint offices by two or more firms;

-by encouraging the provision, on conditions as favourable as possible and equal for all representatives of the above-mentioned bodies, of hotel accommodations, means of communication, and of other facilities normally required by them, as well as of suitable business and residential premises for purposes of permanent representation;

recognize the importance of such measures to encourage greater participation by small- and medium-sized firms in trade between participating States.

\section{Economic and commercial information}

The participating States,

Conscious of the growing role of economic and commercial information in the development of international trade,

Considering that economic information should be of such a nature as to allow adequate market analysis and to permit the preparation of medium- and long-term forecasts, thus contributing to the establishment of a continuing flow of trade and a better utilization of commercial possibilities,

Expressing their readiness to improve the quality and increase the quantity and supply of economic and relevant administrative information,

Considering that the value of statistical information on the international level depends to a considerable extent on the possibility of its comparability, 
will promote the publication and dissemination of economic and commercial information at regular intervals and as quickly as possible, in particular:

-statistics concerning production, national income, budget, consumption and productivity;

-foreign trade statistics drawn up on the basis of comparable classification including breakdown by product with indication of volume and value, as well as country of origin or destination;

- laws and regulations concerning foreign trade;

-information allowing forecasts of development of the economy to assist in trade promotion, for example, information on the general orientation of national economic plans and programmes;

-other information to help businessmen in commercial contacts, for example, periodic directories, lists, and where possible, organizational charts of firms and organizations concerned with foreign trade;

will in addition to the above encourage the development of the exchange of economic and commercial information through, where appropriate, joint commissions for economic, scientific and technical cooperation, national and joint chambers of commerce, and other suitable bodies;

will support a study in the framework of the United Nations Economic Commission for Europe, of the possibilities of creating a multilateral system of notification of laws and regulations concerning foreign trade and changes therein;

will encourage international work on the harmonization of statistical nomenclatures, notably in the United Nations Economic Commission for Europe.

\section{Marketing}

The participating States, 


\section{THE HELSINKI PROCESS}

Recognizing the importance of adapting production to the requirements of foreign markets in order to ensure the expansion of international trade,

Conscious of the need of exporters to be as fully familiar as possible with and take account of the requirements of potential users,

will encourage organizations, enterprises and firms concerned with foreign trade to develop further the knowledge and techniques required for effective marketing;

will encourage the improvement of conditions for the implementation of measures to promote trade and to satisfy the needs of users in respect of imported products, in particular through market research and advertising measures as well as, where useful, the establishment of supply facilities, the furnishing of spare parts, the functioning of after sales services, and the training of the necessary local technical personnel;

will encourage international co-operation in the field of trade promotion, including marketing, and the work undertaken on these subjects within the international bodies, in particular the United Nations Economic Commission for Europe.

\section{Industrial co-operation and projects of common interest}

\section{Industrial co-operation}

The participating States,

Considering that industrial co-operation, being motivated by economic considerations, can

-create lasting ties thus strengthening long-term overall economic co-operation, 
-contribute to economic growth as well as to the expansion and diversification of international trade and to a wider utilization of modern technology,

- lead to the mutually advantageous utilization of economic complementarities through better use of all factors of production, and

-accelerate the industrial development of all those who take part in such co-operation,

propose to encourage the development of industrial cooperation between the competent organizations, enterprises and firms of their countries;

consider that industrial co-operation may be facilitated by means of intergovernmental and other bilateral and multilateral agreements between the interest parties;

note that in promoting industrial co-operation they should bear in mind the economic structures and the development levels of their countries;

note that industrial co-operation is implemented by means of contracts concluded between competent organizations, enterprises and firms on the basis of economic considerations;

express their willingness to promote measures designed to create favourable conditions for industrial co-operation; recognize that industrial co-operation covers a number of forms of economic relations going beyond the framework of conventional trade, and that in concluding contracts on industrial co-operation the partners will determine jointly the appropriate forms and conditions of co-operation, taking into account their mutual interests and capabilities;

recognize further that, if it is in their mutual interest, concrete forms such as the following may be useful for the development of industrial co-operation: joint production and sale, specialization in production and sale, construction, adaptation and modernization of industrial plants, co-operation for the setting up of complete industrial installations with a view to thus obtaining part of the resultant products, 


\section{THE HELSINKI PROCESS}

mixed companies, exchanges of "know-how", of technical information, of patents and of licenses, and joint industrial research within the framework of specific co-operation projects;

recognize that new forms of industrial co-operation can be applied with a view to meeting specific needs;

note the importance of economic, commercial, technical and administrative information such as to ensure the development of industrial co-operation;

Consider it desirable:

- to improve the quality and the quantity of information relevant to industrial co-operation, in particular the laws and regulations, including those relating to foreign exchange, general orientation of national economic plans and programmes as well as programme priorities and economic conditions of the market; and

$\rightarrow$ to disseminate as quickly as possible published documentation thereon;

will encourage all forms of exchange of information and communication of experience relevant to industrial cooperation, including through contacts between potential partners and, where appropriate, through joint commissions for economic, industrial, scientific and technical co-operation, national and joint chambers of commerce, and other suitable bodies;

consider it desirable, with a view to expanding industrial co-operation, to encourage the exploration of co-operation possibilities and the implementation of co-operation projects and will take measures to this end, inter alia, by facilitating and increasing all forms of business contacts between competent organizations, enterprises and firms and between their respective qualified personnel;

note that the provisions adopted by the Conference relating to business contacts in the economic and commercial fields also apply to foreign organizations, enterprises and 
firms engaged in industrial co-operation, taking into account the specific conditions of this co-operation, and will endeavour to ensure, in particular, the existence of appropriate working conditions for personnel engaged in the implementation of co-operation projects;

consider it desirable that proposals for industrial cooperation projects should be sufficiently specific and should contain the necessary economic and technical data, in particular preliminary estimates of the cost of the project, information on the form of co-operation envisaged, and market possibilities, to enable potential partners to proceed with initial studies and to arrive at decisions in the shortest possible time;

will encourage the parties concerned with industrial cooperation to take measures to accelerate the conduct of negotiations for the conclusion of co-operation contracts;

recommend further the continued examination-for example within the framework of the United Nations Economic Commission for Europe- of means of improving the provision of information to those concerned on general conditions of industrial co-operation and guidance on the preparation of contracts in this field;

consider it desirable to further improve conditions for the implementation of industrial co-operation projects, in particular with respect to:

-the protection of the interests of the partners in industrial co-operation projects, including the legal protection of the various kinds of property involved;

- the consideration, in ways that are compatible with their economic systems, of the needs and possibilities of industrial co-operation within the framework of economic policy and particular in national economic plans and programmes;

consider it desirable that the partners, when concluding industrial co-operation contracts, should devote due attention 


\section{THE HELSINKI PROCESS}

to provisions concerning the extension of the necessary mutual assistance and the provision of the necessary information during the implementation of these contracts, in particular with a view to attaining the required technical level and quality of the products resulting from such co-operation; recognize the usefulness of an increased participation of small- and medium-sized firms in industrial co-operation projects.

\section{Projects of common interest}

The participating States,

Considering that their economic potential and their natural resources permit, through common efforts, long-term co-operation in the implementation, including at the regional or sub-regional level, of major projects of common interest, and that these may contribute to the speeding-up of the economic development of the countries participating therein,

Considering it desirable that the competent organizations, enterprises and firms of all countries should be given the possibility of indicating their interest in participating in such projects, and, in case of agreement, of taking part in their implementation,

Noting that the provisions adopted by the Conference relating to industrial cooperation are also applicable to projects of common interest,

regard it as necessary to encourage, where appropriate, the investigation by competent and interested organizations, enterprises and firms of the possibilities for the carrying out of projects of common interest in the fields of energy resources and of the exploitation of raw materials, as well as of transport and communications;

regard it as desirable that organizations, enterprises and firms exploring the possibilities of taking part in projects of common interest exchange with their potential partners, 
through the appropriate channels, the requisite economic, legal, financial and technical information pertaining to these projects;

consider that the fields of energy resources, in particular, petroleum, natural gas and coal, and the extraction and processing of mineral raw materials, in particular, iron ore and bauxite, are suitable ones for strengthening long-term economic co-operation and for the development of trade which could result;

Consider that possibilities for projects of common interest with a view to long-term economic co-operation also exist in the following fields:

-xchanges of electrical energy within Europe with a view to utilizing the capacity of the electrical power stations as rationally as possible;

- co-operation in research for new sources of energy and, in particular, in the field of nuclear energy;

-development of road networks and co-operation aimed at establishing a coherent navigable network in Europe;

-co-operation in research and the perfecting of equipment for multimodal transport operations and for the handling of containers;

-recommend that the States interested in projects of common interest should consider under what conditions it would be possible to establish them, and if they so desire, create the necessary conditions for their actual implementation.

\section{Provisions concerning trade and industrial co-operation}

\section{Harmonization of standards}

The participating States, 


\section{THE HELSINKI PROCESS}

Recognizing the development of international harmonization of standards and technical regulations and of international co-operation in the field of certification as an important means of eliminating technical obstacles to international trade and industrial co-operation, thereby facilitating their development and increasing productivity,

reaffirm their interest to achieve the widest possible international harmonization of standards and technical regulations;

express their readiness to promote international agreements and other appropriate arrangements on acceptance of certificates of conformity with standards and technical regulations;

consider it desirable to increase international co-operation on standardization, in particular by suprorting the activities of intergovernmental and other appropriate organizations in this field.

\section{Arbitration}

The participating States,

Considering that the prompt and equitable settlement of disputes which may arise from commercial transactions relating to goods and services and contracts for industrial co-operation would contribute to expanding and facilitating trade and co-operation,

Considering that arbitration is an appropriate means of settling such disputes,

recommend, where appropriate, to organizations, enterprises and firms in their countries, to include arbitration clauses in commercial contracts and industrial co-operation contracts, or in special agreements;

recommend that the provisions on arbitration should provide for arbitration under a mutually acceptable set of arbitration rules, and permit arbitration in a third country, 
taking into account existing intergovernmental and other agreements in this field.

\section{Specific bilateral arrangements}

The participating States,

Conscious of the need to facilitate trade and to promote the application of new forms of industrial co-operation.

will consider favourably the conclusion, in appropriate cases, of specific bilateral agreements concerning various problems of mutual interest in the fields of commercial exchanges and industrial co-operation, in particular with a view to avoiding double taxation and to facilitating the transfer of profits and the return of the value of the assets invested.

\section{Science and technology}

The participating States,

Convinced that scientific and technological co-operation constitutes an important contribution to the strengthening of security and co-operational among them, in that it assists the effective solution of problems of common interest and the improvement of the conditions of human life,

Considering that in developing such co-operation, it is important to promote the sharing of information and experience, facilitating the study and transfer of scientific and technological achievements, as well as the access to such achievements on a mutually advantageous basis and in fields of co-operation agreed between interested parties,

Considering that it is for the potential partners, i.e., the competent organizations, institutions, enterprises, scientists and technologists of the participating States to determine the opportunities for mutually beneficial co-operation and to develop its details, 


\section{THE HELSINKI PROCESS}

Affirming that such co-operation can be developed and implemented bilaterally and multilaterally at the governmental and non-governmental levels, for example, through intergovernmental and other agreements, international programmes, co-operative projects and commercial channels, while utilizing also various forms of contacts, including direct and individual contacts,

Award of the need to take measures further to improve scientific and technological co-operation between them.

\section{Possibilities for improving co-operation}

Recognize that possibilities exist for further improving scientific and technological co-operation, and to this end, express their intention to remove obstacles to such co-operation, in particular through:

-the improvement of opportunities for the exchange and dissemination of scientific and technological information among the parties interested in scientific and technological research and co-operation including information related to the organization and implementation of such co-operation;

-the expeditious implementation and improvement in organization, including programmes, of international visits of scientists and specialists in connexion with exchanges, conferences and co-operation;

- the wider use of commercial channels and activities for applied scientific and technological research and for the transfer of achievements obtained in this field while providing information and protection of intellectual and industrial property rights;

\section{Fields of co-operation}

Consider that possibilities to expand co-operation exist within the areas given below as examples, noting that it 
is for potential partners in the participating countries to identify and develop projects and arrangements of mutual interest and benefit:

\section{Agriculture}

Researching into new methods and technologies for increasing the productivity of crop cultivation and animal husbandry; the application of chemistry to agriculture; the design, construction and utilization of agricultural machinery; technologies of irrigation and other agricultural land improvement works;

\section{Energy}

New technologies of production, transport and distribution of energy aimed at improving the use of existing fuels and sources of hydroenergy, as well as research in the field of new energy sources, including nuclear, solar and geothermal energy;

New technologies, rational use of resources

Research on new technologies and equipment designed in particular to reduce energy consumption and to minimize or eliminate waste;

\section{Transport technology}

Research on the means of transport and the technology applied to the development and operation of international, national and urban transport networks including container transport as well as transport safety;

Physics

Study of problems in high energy physics and plasma physics; research in the field of theoretical and experimental nuclear physics;

Chemistry

Research on problems in electrochemistry and the chemistry of polymers, of natural products, and of metals and alloys, as well as the development of improved chemical technology, especially materials processing; practical application of the latest achievements of chemistry to industry, construction and other sectors of the economy; 


\section{THE HELSINKI PROCESS}

Meteorology and hydrology

Meteorological and hydrological research, including methods of collection, evaluation and transmission of data and their utilization for weather forecasting and hydrology fcrecasting;

Oceanography

Oceanographic research, including the study of air/sea interactions;

Seismological research

Study and forecasting of earthquakes and associated geological changes; development and research of technology of seism-resisting constructions;

Research on glaciology, permafrost and problems of life under conditions of cold

Research on glaciology and permafrost; transportation and construction technologies; human adaptation to climatic extremes and changes in the living conditions of indigenous populations;

Computer, communication and information technologies

Development of computers as well as of telecommunications and information systems; technology associated with computers and telecommunications, including their use for management systems, for production processes, for automation, for the study of economic problems, in scientific research and for the collection, processing and dissemination of information;

Space research

Space exploration and the study of the earth's natural resources and the natural environment by remote sensing in particular with the assistance of satellites and rocketprobes;

Medicine and public health

Research on cardiovascular, tumor and virus diseases, molecular biology, neurophysiology; development and testing of new drugs; study of contemporary problems of pediat- 
THE FINAL ACT

rics, gerontology and the organization and techniques of medical services;

Environmental research

Research on specific scientific and technological problems related to human environment.

\section{Forms and methods of co-operation}

Express their view that scientific and technological cooperation should, in particular, employ the following forms and methods:

-exchange and circulation of books, periodicals and other scientific and technological publications and papers among interested organizations, scientific and technological institutions, enterprises and scientists and technologists, as well as participation in international programmers for the abstracting and indexing of publications;

- exchanges and visits as well as other direct contacts and communications among scientists and technologists. on the basis of mutual agreement and other arrangements, for such purposes as consultations, lecturing and conducting research, including the use of laboratories, scientific libraries, and other documentation centres in connexion therewith; -holding of international and national conferences, symposia, seminars, courses and other meetings of a scientific and technological character, which would include the participation of foreign scientists and technologists;

-joint preparation and implementation of programmes and projects of mutual interest on the basis of consultation and agreement among all parties concerned, including, where possible and appropriate, exchanges of experience and research results, and correlation of research programmes, between scientific and technological research institutions and organizations; 


\section{THE HELSINKI PROCESS}

-use of commercial channels and methods for identifying and transferring technological and scientific developments, including the conclusion of mutually beneficial cooperation arrangements between firms and enterprises in fields agreed upon between them and for carrying out, where appropriate, joint research and development programmes and projects;

consider it desirable that periodic exchanges of views and information take place on scientific policy, in particular on general problems of orientation and administration of research and the question of a better use of large-scale scientific and experimental equipment on a co-operative basis;

recommend that, in developing co-operation in the field of science and technology, full use be made of existing practices of bilateral and multilateral co-operation, including that of a regional or sub-regional character, together with the forms and methods of co-operation described in this document;

recommend further that more effective utilization be made of the possibilities and capabilities of existing international organizations, intergovernmental and non-governmental, concerned with science and technology, for improving exchanges of information and experience, as well as for developing other forms of co-operation in fields of common interest, for example:

-in the United Nations Economic Commission for Europe, study of possibilities for expanding multilateral cooperation, taking into account models for projects and research used in various international organizations; and for sponsoring conferences, symposia, and study and working groups such as those which would bring together younger scientists and technologists with eminent specialists in their field; 
THE FINAL ACT

-through their participation in particular international scientific and technological co-operation programmes, including those of UNESCO and other international organizations, pursuit of continuing progress towards the objectives of such programmes, notably those of UNISIST [World Science Information System] with particular respect to information policy guidance, technical advice, information contributions and data processing.

\section{Environment}

The participating States,

Affirming that the protection and improvement of the environment, as well as the protection of nature and the rational utilization of its resources in the interests of present and future generations, is one of the tasks of major importance to the well-being of peoples and the economic development of all countries and that many environmental problems, particularly in Europe, can be solved effectively only through close international co-operation,

Acknowledging that each of the participating States, in accordance with the principles of international law, ought to ensure, in a spirit of co-operation, that activities carried out on its territory do not cause degradation of the environment in another State or in areas lying beyond the limits of national jurisdiction,

Considering that the success of any environmental policy presupposes that all population groups and social forces, aware of their responsibilities, help to protect and improve the environment, which necessitates continued and thorough educative action, particularly with regard to youth,

Affirming that experience has shown that economic development and technological progress must be compatible with the protection of the environment and the preservation of historical and cultural values; that damage to the environment is best avoided by preventive measures; and that the 
THE HELSINKI PROCESS

ecological balance must be preserved in the exploitation and management of natural resources,

\section{Aims of co-operations}

Agree to the following aims of co-operation, in particular:

-to study, with a view to their solution, those environmental problems which, by their nature, are of a multilateral, bilateral, regional or sub-regional dimension; as well as to encourage the development of an interdisciplinary approach to environmental problems;

- to increase the effectiveness of national and international measures for the protection of the environment, by the comparison and, if appropriate, the harmonization of methods of gathering and analyzing facts, by improving the knowledge of pollution phenomena and rational utilization of natural resources, by the exchange of information, by the harmonization of definitions and the adoption, as far as possible, of a common terninology in the field of the environment;

- to take the necessary measures to bring environmental policies closer together and, where appropriate and possible, to harmonize them;

-to encourage, where possible and appropriate, national and international efforts by their interested organizations, enterprises and firms in the development, production and improvement of equipment designed for monitoring, protecting and enhancing the environment.

\section{Fields of co-operation}

To attain these aims, the participating States will make use of every suitable opportunity to co-operate in the field 
of environment and, in particular, within the areas described below as examples:

Control of air pollution

Desulphurization of fossil fuels and exhaust gases; pollution control of heavy metals, particles, aerosols, nitrogen oxides, in particular those emitted by transport, power stations, and other industrial plants; systems and methods of observation and control of air pollution and its effects, including long-range transport of air pollutants;

Water pollution control and fresh water utilization

Prevention and control of water pollution, in particular of transboundary rivers and international lakes; techniques for the improvement of the quality of water and further development of ways and means for industrial and municipal sewage effluent purification; methods of assessment of fresh water resources and the improvement of their utilization, in particular by developing methods of production which are less polluting and lead to less consumption of fresh water;

Protection of the marine environment

Protection of the marine envircnment of participating States, and especially the Mediterranean Sea, from pollutants emanating from land-based sources and those from ships and other vessels, notably the harmful substances listed in Annexes I and II to the London Convention on the Prevention of Marine Pollution by the Dumping of Wastes and Other Matters; problems of maintaining marine ecological balances and food chains, in particular such problems as may arise from the exploration and exploitation of biological and mineral resources of the seas and the sea-bed;

Land utilization and soils

Problems associated with more effective use of lands, including land amelioration, reclamation and recultivation; control of soil pollution, water and air erosion, as well as other forms of soil degradation; maintaining and increasing the productivity of soils with due regard for the possible 


\section{THE HELSINKI PROCESS}

negative effects of the application of chemical fertilizers and pesticides;

Nature conservation and nature reserves

Protection of nature and nature reserves; conservation and maintenance of existing genetic resources, especially rare animal and plant species; conservation of natural ecological systems; establishment of nature reserves and other protected landscapes and areas, including their use for research, tourism, recreation and other purposes;

Improvement of environmental conditions in areas of human settlement

Environmental conditions associated with transport, housing, working areas, urban development and planning, water supply and sewage disposal systems; assessment of harmful effects of noise, and noise control methods; collection, treatment and utilization of wastes, including the recovery and recycling of materials; research on substitutes for non-biodegradable substances;

Fundamental research, monitoring, forecasting and assessment of environmental changes

Study of changes in climate, landscapes and ecological balances under the impact of both natural factors and human activities; forecasting of possible genetic changes in flora and fauna as a result of environmental pollution; harmonization of statistical data, development of scientific concepts and systems of monitoring networks, standardized methods of observation, measurement and assessment of changes in the biosphere; assessment of the effects of environmental pollution levels and degradation of the environment upon human health; study and development of criteria and standards for various environmental pollutants and regulation regarding production and use of various products;

Legal and administrative measures

Legal and administrative measures for the protection of the environment including procedures for establishing environmental impact assessments. 


\section{Forms and methods of co-operation}

The participating States declare that problems relating to the protection and improvement of the environment will be solved on both a bilateral and a multilateral, including regional and sub-regional, basis, making full use of existing patterns and forms of co-operation. They will develop cooperation in the field of the environment in particular by taking into consideration the Stockholm Declaration on the Human Environment, relevant resolutions of the United Nations General Assembly and the United Nations Economic Commission for Europe Prague symposium on environmental problems.

The participating States are resolved that, co-operation in the field of the environment will be implemented in particular through:

-exchanges of scientific and technical information, documentation and research results, including information on the means of determining the possible effects on the environment of technical and economic activities;

-organization of conferences, symposia and meetings of experts;

-exchanges of scientists, specialists and trainees;

- joint preparation and implementation of programmes and projects for the study and solution of various problems of environmental protection;

-harmonization, where appropriate and necessary, of environmental protection standards and norms, in particular with the object of avoiding possible difficulties in trade which may arise from efforts to resolve ecological problems of production processes and which relate to the achievement of certsin environmental qualities in manufactured products;

-consultations on various aspects of environmental protection, as agreed upon among countries concerned, especially in connexion with problems which could have international consequences. 


\section{THE HELSINKI PROCESS}

The participating States will further develop such cooperation by:

-promoting the progressive development, codification and implementation of international law as one means of preserving and enhancing the human environment, including principles and practices, as accepted by them, relating to pollution and other environmental damage caused by activities within the jurisdiction or control of their States affecting other countries and regions;

-supporting and promoting the implementation of relevant international Conventions to which they are parties, in particular those designed to prevent and combat marine and fresh water pollution, recommending States to ratify Conventions which have already been signed, as well as considering possibilities of accepting other appropriate Conventions to which they are not parties at present;

-advocating the inclusion, where appropriate and possible, of the various areas of co-operation into the programmes of work of the United Nations Economic Commission for Europe, supporting such co-operation within the framework of the Commission and of the United Nations Environment Programme, and taking into account the work of other competent international organizations of which they are members;

-making wider use, in all types of co-operation, of information already available from national and international sources, including internationally agreed criteria, and utilizing the possibilities and capabilities of various competent international organizations.

The participating States agree on the following recommendations on specific measures:

- to develop through international co-operation an extensive programme for the monitoring and evaluation of the long-range transport of air pollutants, starting with sulphur dioxide and with possible extension to other pollutants, 
and to this end to take into account basic elements of a co-operation programme which were identified by the experts who met in Oslo in December 1974 at the invitation of the Norwegian Institute of Air Research;

- to advocate that within the framework of the United Nations Economic Commission for Europe a study be carried out of procedures and relevant experience relating to the activities of Governments in developing the capabilities of their countries to predict adequately environmental consequences of economic activities and technological development.

\section{Co-operation in other areas}

\section{Development of transport}

The participating States,

Considering that the improvement of the conditions of transport constitutes one of the factors essential to the development of co-operation among them,

Considering that it is necessary to encourage the development of transport and the solution of existing problems by employing appropriate national and international means,

Taking into account the work being carried out on these subjects by existing international organizations, especially by the Inland Transport Committee of the United Nations Economic Commission for Europe,

note that the speed of technical progress in the various fields of transport makes desirable a development of cooperation and an increase in exchanges of information among them;

declare themselves in favour of a simplification and a harmonization of administrative formalities in the field of international transport, in particular at frontiers;

consider it desirable to promote, while allowing for their particular national circumstances in this sector, the 


\section{THE HELSINKI PROCESS}

harmonization of administrative and technical provisions concerning safety in road, rail, river, air and sea transport;

express their intention to encourage the development of international inland transport of passengers and goods as well as the possibilities of adequate participation in such transport on the basis of reciprocal advantage;

declare themselves in favour, with due respect for their rights and international commitments, of the elimination of disparities arising from the legal provisions applied to traffic on inland waterways which are subject to international conventions and, in particular, of the disparity in the application of those provisions; and to this end invite the member States of the Central Commission for the Navigation of the Rhine of the Danube Commission and of other bodies to develop the work and studies now being carried out, in particular within the United Nations Economic Commission for Europe;

express their willingness, with a view to improving international rail transport and with due respect for their rights and international commitments, to work towards the elimination of difficulties arising from disparities in existing international legal provisions governing the reciprocal railway transport of passengers and goods between their territories;

express the desire for intensification of the work being carried out by existing international organizations in the field of transport, especially that of the Inland Transport Committee of the United Nations Economic Commission for Europe, and express their intention to contribute thereto by their efforts;

consider that examination by the participating States of the possibility of their accession to the different conventions or to membership of international organizations specializing in transport matters, as well as their efforts to implement conventions when ratified, could contribute to the strengthening of their co-operation in this field. 


\section{Promotion of tourism}

The participating States,

Aware of the contribution made by international tourism to the development of mutual understanding among peoples, to increased knowledge of other countries' achievements in various fields, as well as to economic, social and cultural progress,

Recognizing the interrelationship between the development of tourism and measures taken in other areas of economic activity,

express their intention to encourage increased tourism on both an individual and group basis in particular by:

-encouraging the improvement of the tourist infrastructure and co-operation in this field;

-encouraging the carrying out of joint tourist projects including technical co-operation, particularly where this is suggested by territorial proximity and the convergence of tourist interests;

-encouraging the exchange of information, including relevant laws and regulations, studies, data and documentation relating to tourism, and by improving statistics with a view to facilitating their comparability;

-dealing in a positive positive spirit with questions connected with the allocation of financial means for tourist travel abroad, having regard to their economic possibilities, as well as with those connected with the formalities required for such travel, taking into account other provisions on tourism adopted by the Conference;

- facilitating the activities of foreign travel agencies and passenger transport companies in the promotion of international tourism;

—encouraging tourism outside the high season; 


\section{THE HELSINKI PROCESS}

-examining the possibilities of exchanging specialists and students in the field of tourism, with a view to improving their qualifications;

-promoting conferences and symposia on the planning and development of tourism;

-consider it desirable to carry out in the appropriate international framework, and with the co-operation of the relevant national bodies, detailed studies on tourism, in particular;

- a comparative study on the status and activities of travel agencies as well as on ways and means of achieving better co-operation among them;

- a study of the problems raised by the seasonal concentration of vacations, with the ultimate objective of encouraging tourism outside peak periods;

-studies of the problems arising in areas where tourism has injured the environment;

consider also that interested parties might wish to study the following questions:

-uniformity of hotel classification; and

-tourist routes comprising two or more countries;

will endeavor, where possible, to ensure that the development of tourism does not injure the environment and the artistic, historic and cultural heritage in their respective countries;

will pursue their co-operation in the field of tourism bilaterally and multilaterally with a view to attaining the above objectives.

\section{Economic and social aspects of migrant labour}

The participating States, 
Considering that the movements of migrant workers in Europe have reached substantial proportions, and that they constitute an important economic, social and human factor for host countries as well as for countries of origin,

Recognizing that workers' migrations have also given rise to a number of economic, social, human and other problems in both the receiving countries and the countries of origin,

Taking due account of the activities of the competent international organizations, more particularly the International Labour Organisation, in this area,

are of the opinion that the problems arising bilaterally from the migration of workers in Europe as well as between the participating States should be dealt with by the parties directly concerned, in order to resolve these problems in their mutual interest, in the light of the concern of each State involved to take due account of the requirements resulting from its socio-economic situation, having regard to the obligation of each State to comply with the bilateral and multilateral agreements to which it is party, and with the following aims in view:

to encourage the efforts of the countries of origin directed towards increasing the possibilities of employment for their nationals in their own territories, in particular by developing economic co-operation appropriate for this purpose and suitable for the host countries and the countries of origin concerned;

to ensure, through collaboration between the host country and the country of origin, the conditions under which the orderly movement of workers might take place, while at the same time protecting their personal and social welfare and, if appropriate, to organize the recruitment of migrant workers and the provision of elementary language and vocational training; 


\section{THE HELSINKI PROCESS}

to ensure equality of rights between migrant workers and nationals of the host countries with regard to conditions of employment and work and to social security, and to endeavour to ensure that migrant workers may enjoy satisfactory living conditions, especially housing conditions;

to endeavour to ensure, as far as possible, that migrant workers may enjoy the same opportunities as nationals of the host countries of finding other suitable employment in the event of unemployment;

to regard with favour the provision of vocational training to migrant workers and, as far as possible, free instruction in the language of the host country, in the framework of their employment;

to confirm the right of migrant workers to receive, as far as possible, regular information in their own language, covering both their country of origin and the host country;

to ensure that the children of migrant workers established in the host country have access to the education usually given there, under the same conditions as the children of that country and, furthermore, to permit them to receive supplementary education in their own language, national culture, history and geography;

to bear in mind that migrant workers, particularly those who have acquired qualifications, can, by returning to their countries after a certain period of time, help to remedy any deficiency of skilled labor in their country of origin;

to facilitate, as far as possible, the reuniting of migrant workers with their families;

to regard with favour the efforts of the countries of origin to attract the savings of migrant workers, with a view to increasing, within the framework of their economic development, appropriate opportunities for employment, thereby facilitating the reintegration of these workers on their return home. 


\section{Training of personnel}

The participating States,

Conscious of the importance of the training and advanced training of professional staff and technicians for the economic development of every country,

declare themselves willing to encourage co-operation in this field notably by promoting exchange of information on the subject of institutions, programmes and methods of training and advanced training open to professional staff and technicians in the various sectors of economic activity and especially in those of management, public planning, agriculture and commercial and banking techniques;

consider that it is desirable to develop, under mutually acceptable conditions, exchanges of professional staff and technicians, particularly through training activities, of which it would be left to the competent and interested bodies in the participating States to discuss the modalities-duration, financing, education and qualification levels of potential participants;

declare themselves in favour of examining, through appropriate channels, the possibilities of co-operating on the organization and carrying out of vocational training on the job, more particularly in professions involving modern techniques.

\section{QUESTIONS RELATING TO SECURITY AND CO-OPERATION IN THE MEDITERRANEAN}

The participating States,

Conscious cil the geographical, historical, cultural, economic and political aspects of their relationship with the non-participating Mediterranean States,

Convinced that security in Europe is to be considered in the broader context of world security and is closely 


\section{THE HELSINKI PROCESS}

linked with security in the Mediterranean area as a whole, and that accordingly the process of improving security should not be confined to Europe but should extend to other parts of the world, and in particular to the Mediterranean area,

Believing that the strengthening of security and the intensification of co-operation in Europe would stimulate positive processes in the Mediterranean region, and expressing their intention to contribute towards peace, security and justice in the region, in which ends the participating States and the non-participating Mediterranean States have a common interest,

Recognizing the importance of their mutual economic relations with the non-participating Mediterranean States, and conscious of their common interest in the further development of co-operation,

Noting with appreciation the interest expressed by the non-participating Mediterranean States in the Conference since its inception, and having duly taken their contributions into account,

\section{Declare their intention:}

- to promote the development of good neighbouriy relations with the non-participating Mediterranean States in conformity with the purposes and principles of the Charter of the United Nations, on which their relations are based, and with the United Nations Declaration on Principles of International Law concerning Friendly Relations and Cooperation annong States and accordingly, in this context, to conduct their relations with the non-participating Mediterranean States in the spirit of the principles set forth in the Declaration on Principles Guiding Relations between Participating States;

-to seek, by further improving their relations with the non-participating Mediterranean States, to increase mu- 
tual confidence, so as to promote security and stability in the Mediterranean area as a whole;

- to encourage with the non-participating Mediterranean States the development of mutually beneficial co-operation in the various fields of economic activity, especially by expanding commercial exchanges, on the basis of a common awareness of the necessity for stability and progress in trade relations, of their mutual economic interests, and of differences in the levels of economic development, thereby promoting their economic advancement and well-being;

-to contribute to a diversified development of the economies of the non-participating. Mediterranean countries, whilst taking due account of their national development objectives, and to co-operate with them, especially in the sectors of industry, science and technology, in their efforts to achieve a better utilization of their resources, thus promoting a more harmonious development of economic relations;

- to intensify their efforts and their co-operation on a bilateral and multilateral basis with the non-participating Mediterranean States directed towards the improvement of the en ironment of the Mediterranean, especially the safeguarding of the biological resources and ecological balance of the sea, by appropriate measures including the prevention and control of pollution; to this end, and in view of the present situation, to co-operate through competent international organizations and in particular within the United Nations Environment Programme (UNEP);

- to promote further contacts and co-operation with the non-participating Mediterranean States in other relevant fields.

In order to advance the objectives set for the above, the participating States also declare their intention of maintaining and amplifying the contacts and dialogue as initiated by the CSCE with the non-participating Mediterranean States to include all the States of the Mediterranean, with the purpose of contributing to peace, reducing armed forces 


\section{THE HELSINKI PROCESS}

in the region, strengthening security, lessening tensions in the region, and widening the scope of co-operation, ends in which all share a common interest, as well as with the purpose of defining further common objectives.

The participating States would seek, in the framework of their multilateral efforts, to encourage progress and appropriate initiatives and to proceed to an exchange of views on the attainment of the above purposes.

\section{CO-OPERATION IN HUMANITARIAN AND OTHER FIELDS}

The participating States,

Desiring to contribute to the strengthening of peace and understanding among peoples and to the spiritual enrichment of the human personality without distinction as to race, sex, language or religion,

Conscious that increased cultural and educational exchanges, broader dissemination of information, contacts between people, and the solution of humanitarian problems will contribute to the attainment of these aims.

Determined therefore to co-operate among themselves, irrespective of their political, economic and social systems, in order to create better conditions in the above fields, to develop and strengthen existing forms of co-operation and to work out new ways and means appropriate to these aims,

Convinced that this co-operation should take place in full respect for the principles guiding relations among participating States as set forth in the relevant document,

Have adopted the following: 


\section{Human Contacts}

The participating States,

Considering the development of contacts to be an important element in the strengthening of friendly relations and trust among peoples,

Affirming in relation to their present effort to improve conditions in this area, the importance they attach to humanitarian considerations,

Desiring in this spirit to develop, with the continuance of détente, further efforts to achieve continuing progress in this field,

And conscious that the questions relevant hereto must be settled by the States concerned under mutually acceptable conditions,

Make it their aim to facilitate freer movement and contacts, individually and collectively, whether privately or officially, among persons, institutions and organizations of the participating States, and to contribute to the solution of the humanitarian problems that arise in that connexion,

Declare their readiness to these ends to take measures which they consider appropriate and to conclude agreements or arrangements among themselves, as may be needed, and

Express their intention now to proceed to the implementation of the following:

\section{(a) Contacts and Regular Meetings on the Basis of Family Ties}

In order to promote further development of contacts on the basis of family ties the participating States will favourably consider applications for travel with the purpose of allowing persons to enter or leave their territory temporarily, and on a regular basis if desired, in order to visit members of their families. 


\section{THE HELSINKI PROCESS}

Applications for temporary visits to meet members of their families will be dealt with without distinction as to the country of origin or destination: existing requirements for travel documents and visas will be applied in this spirit. The preparation and issue of such documents and visas will be effected within reasonable time limits; cases of urgent necessity-such as serious illness or death-will be given priority treatment. They will take such steps as may be necessary to ensure that the fees for official travel documents and visas are acceptable.

They confirm that the presentation of an application concerning contacts on the basis of family ties will not modify the rights and obligations of the applicant or of members of his family.

\section{(b) Reunification of Families}

The participating States will deal in a positive and humanitarian spirit with the applications of persons who wish to be reunited with members of their family, with special attention being given to requests of an urgent character-such as requests submitted by persons who are ill or old.

They will deal with applications in this field as expeditiously as possible.

They will lower where necessary the fees charged in connexion with these applications to ensure that they are at a moderate level,

Applications for the purpose of family reunification which are not granted may be renewed at the appropriate level and will be reconsidered at reasonably short intervals by the authorities of the country of residence or destination, whichever is concerned; under such circumstances fees will be charged only when applications are granted.

Persons whose applications for family reunification are granted may bring with them or ship their household and 
personal effects; to this end the participating States will use all possibilities provided by existing regulations.

Until members of the same family are reunited meetings and contacts between them may take place in accordance with the modalities for contacts on the basis of family ties.

The participating States will support the efforts of Red Cross and Red Crescent Societies concerned with the problems of family reunification.

They confirm that the presentation of an application concerning family reunification will not modify the rights and obligations of the applicant or of members of his family.

The receiving participating State will take appropriate care with regard to employment for persons from other participating States who take up permanent residence in that State in connexion with family reunification with its citizens and see that they are afforded opportunities equal to those enjoyed by its own citizens for education, medical assistance and social security.

\section{(c) Marriage Between Citizens of Different States}

The participating States will examine favourably and on the basis of humanitarian considerations requests for exit or entry permits from persons who have decided to marry a citizen from another participating State.

The processing and issuing of the documents required for the above purposes and for the marriage will be in accordance with the provisions accepted for family reunification.

In dealing with requests from couples from different participating States, once married to enable them and the minor children of their marriage to transfer their permanent residence to a State in which either one is normally a resident, the participating States will also apply the provisions accepted for family reunification. 


\section{THE HELSINKI PROCESS}

\section{(d) Travel for Personal or Professional Reasons}

The participating States intend to facilitate wider travel by their citizens for personal or professional reasons and to this end they intend particular:

-gradually to simplify and to administer flexibly the procedures for exit and entry;

-to ease regulations concerning movement of citizens from the other participating States in their territory, with due regard to security requirements.

They will endeavour gradually to lower, where necessary, the fees for visas and official travel documents.

They intend to consider, as necessary, means-including, in so far as appropriate, the conclusion of multilateral or bilateral consular conventions or other relevant agreements or understanding - for the imprevement of arrangements to provide consular assistance.

They confirm that religious faiths, institutions and organizations, practising within the constitutional framework of the participating States, and their representatives can, in the field of their activities, have contacts and meetings among themselves and exchange information.

\section{(e) Improvement of Conditions for Tourism on an Individual or Collective Basis}

The participating States consider the tourism contributes to a fuller knowledge of the life, culture and history of other countries, to the growth of understanding among peoples, to the improvement of contacts and to the broader use of leisure. They intend to promote the development 
of tourism, on an individual or collective basis, and, in particular, they intend:

-to promote visits to their respective countries by encouraging the provision of appropriate facilities and the simplification and expediting of necessary formalities relating to such visits;

-to increase, on the basis of appropriate agreements or arrangements where necessary, co-operation in the development of tourism, in particular by considering bilaterally possible ways to increase information relating to travel to other countries and to the reception and service of tourists, and other related questions of mutual interest.

\section{(f) Meetings Among Young People}

The participating States intend to further the development of contacts and exchanges among young people by encouraging:

-increased exchanged and contacts on a short- or longterm basis among young people working, training or undergoing education through bilateral or multilateral agreements, or regular programmes in all cases where it is possible;

- study by their youth organizations of the question of possible agreements relating to frameworks of multilateral youth co-operation;

-agreements or regular programmes relating to the organization of exchanges of students, of international youth seminars, of courses of professional training and foreign language study;

-the further development of youth tourism and the provision to this end of appropriate facilities;

- the development, where possible, of exchanges, contacts and co-operation on a bilateral or multilateral basis between their organizations which represent wide circles of young people working, training or undergoing education; 


\section{THE HELSINKI PROCESS}

-awareness among youth of the importance of developing mutual understanding and of strengthening friendly relations and confidence among peoples.

\section{(g) Sport}

In order to expand existing links and co-operation in the field of sport the participating States will encourage contacts and exchanges of this kind, including sports meetings and competitions of all sorts on the basis of the established international rules, regulations and practice.

\section{(h) Expansion of Contracts}

By way of further developing contacts among governmental institutions and non-governmental organizations and associations, including women's organizations, the participating States will facilitate the convening of meetings as well as travel by delegations, groups and individuals.

\section{Information}

The participating States,

Conscious of the need for an ever wider knowledge and understanding of the various aspects of life in other participating States,

Acknowledging the contribution of this process to the growth of confidence between peoples,

Desiring, with the development of mutual understanding between the participating States and with the further improvement of their relations, to continue further efforts towards progress in this field,

Recognizing the importance of the dissemination of information from the other participating States and of a better acquaintance with such information, 
Emphasizing therefore the essential and influential role of the press, radio, television, cinema and news agencies and of the journalists working in these fields,

Make it their aim to facilitate the freer and wider dissemination of information of all kinds, to encourage cooperation in the field of information and the exchange of information with other countries, and to improve the conditions under which journalists from one participating State exercise their profession in another participating State, and

Express their intention in particular:

(a) Improvement of the Circulation of, Access to, and Exchange of Information

\section{(i) Oral Information}

- To facilitate the dissemination of oral information through the encouragement of lectures and lecture tours by personalities and specialists from the other participating States, as well as exchanges of opinions at round table meetings, seminars, symposia, summer schools, congresses and other bilateral and multilateral meetings.

\section{(ii) Printed Information}

- To facilitate the improvement of the dissemination, on their territory, of newspapers and printed publications, periodical and non-periodical, from the other participating States. For this purpose:

they will encourage their competent firms and organizations to conclude agreements and contracts designed gradua!ly to increase the quantities and the number of titles of newspapers and publications imported from the other participating States. These agreements and contracts should in particular mention the speediest conditions of delivery and the use of the normal channels existing in each country for the distribution of its own publications and newspapers, as well as forms and means of payment agreed between the 


\section{THE HELSINKI PROCESS}

parties making it possible to achieve the objectives aimed at by these agreements and contracts;

where necessary. they will take appropriate measures to achieve the above objectives and to implement the provisions contained in the agreements and contracts.

- To contribute to the improvement of access by the public to periodical and non-periodical printed publications imported on the bases indicated above. In particular:

they will encourage an increase in the number of places where these publications are on sale;

they will facilitate the availability of these periodical publications during congresses, conferences, official visits and other international events and to tourists during the season;

they will develop the possibilities for taking out subscriptions according to the modalities particular to each country;

they will improve the opportunities for reading and borrowing these publications in large public libraries and their reading rooms as well as in university libraries.

They intend to improve the possibilities for acquaintance with bulletins of official information issued by diplomatic missions and distributed by those missions on the basis of arrangements acceptable to the interested parties.

\section{(iii) Filmed and Broadcast Information}

-To promote the improvement of the dissemination of filmed and broadcast information. To this end:

they will encourage the wider showing and broadcasting of a greater variety of recorded and filmed information from the other participating States, illustrating the various aspects of life in their countries and received on the basis of such agreements or arrangements as may be necessary between the organizations and firms directly concerned; 
they will facilitate the import by competent organizations and firms of recorded audio-visual material from the other participating States.

The participating States note the expansion in the dissemination of information broadcast by radio, and express the hope for the continuation of this process, so as to meet the interest of mutual understanding among peoples and the aims set forth by this Conference.

\section{(b) Co-operation in the Field of Information}

- To encourage co-operation in the field of information on the basis of short or long term agreements or arrangements. In particular:

they will favour increased co-operation among mass media organizations, including press agencies, as well as among publishing houses and organizations;

they will favour co-operation among public or private, national or international radio, and and television organizations, in particular through the exchange of both live and recorded radio and television programmes, and through the joint production and the broadcasting and distribution of such programmes;

they will encourage meetings and contacts both between journalists' organizations and between journalists from the participating States;

they will view favourably the possibilities of arrangements, between periodical publications as well as between newspapers from the participating States, for the purpose of exchanging and publishing articles;

they will encourage the exchange of technical information as well as the organization of joint research and meetings devoted to the exchange of experience and views between experts in the field of the press, radio, and television. 
THE HELSINKI PROCESS

\section{(c) Improvement of Working Conditions for Journalists}

The participating States, desiring to improve the conditions under which journalists for one participating State exercise their profession in another participating State, intend in particular to:

-examine in a favourable spirit and within a suitable and reasonable time scale requests from journalists for visas;

- grant to permanently accredited journalists of the participating States, on the basis of arrangements, multiple entry and exit visas for specified periods;

-facilitate the issue to accredited journalists of the participating States of permits for stay in their country of temporary residence and, if and when these are necessary, of other official papers which it is appropriate for them to have;

-ease, on a basis of reciprocity, procedures for arranging travel by journalists of the participating States in the country where they are exercising their profession, and to provide progressively greater opportunities for such travel subject to the observance of regulations relating to the existence of areas closed for security reasons;

-ensure that requests by such journalists for such travel receive, in so far as possible, an expeditious response, taking into account the time scale of the request;

-increase the opportunities for journalists of the participating States to communicate personally with their sources, including organizations and official institutions;

- grant to journalists of the participating States the right to import, subject only to its being taken out again, the technical equipment (photographic, cinematographic, tape 
recorder, radio and television) necessary for the exercise of their profession;*

-enable journalists of the other participating States, whether permanently or temporarily accredited, to transmit completely, normally and rapidly by means recognized by the participating States to the information organs which they represent, the results of their professional activity, including tape recordings and undeveloped film, for the purpose of publication or of broadcasting on the radio or television.

The participating States reaffirm that the legitimate pursuit of their professional activity will neither render journalists liable to expulsion nor otherwise penalize them. If an accredited journalist is expelled, he will be informed of the reasons for this act and may submit an application for reexamination of his case.

\section{Co-operation and Exchanges in the Field of Culture}

The participating States,

Considering that cultural exchanges and co-operation contribute to a better comprehension among people and among peoples, and thus promote a lasting understanding among States.

Confirming the conclusions already formulated in this field at the multilateral level, particularly at the Intergovernmental Conference on Cultural Policies in Europe, organized by UNESCO in Helsinki in June 1972, where interest was manifested in the active participation of the broadest possible social groups in an increasingly diversified cultural life,

*While recognizing that appropriate local personnel are employed by foreign journalists in many instances, the participating States note that the above provisions would be applied, subject to the observance of the appropriate rules, to persons form the other participating States, who are regularly and professionally engaged as technicians, photographers or cameraman of the press, radio, television or cinema. [Footnote in original.] 


\section{THE HELSINKI PROCESS}

Desiring, with the development of mutual confidence and the further improvement of relations between the participating States, to continue further efforts toward progress in this field,

Disposed in this spirit to increase substantially their cultural exchanges, with regard both to persons and to cultural works, and to develop among them an active co-operation, both at the bilateral and the multilateral level, in all the fields of culture,

Convinced that such a development of their mutual relations will contribute to the enrichment of the respective cultures, while respecting the originality of each, as well as to the reinforcement among them of a consciousness of common values, while continuing to develop cultural co-operation with other countries of the world,

Declare that they jointly set themselves the following objectives:

(a) to develop the mutual exchange of intormation with a view to a better knowledge of respective cultural achievements,

(b) to improve the facilities for the exchange and for the dissemination of cultural property,

(c) to promote access by all to respective cultural achievements,

(d) to develop contacts and co-operation among persons active in the field of culture,

(e) to seek new fields and forms of cultural co-operation,

Thus give expression their common will to take progressive, coherent and long-term action in order to achieve the objectives of the present declaration; and

Express their intention now to proceed to the implementation of the following: 


\section{Extension of Relations}

To expand and improve at the various levels co-operation and links in the field of culture, in particular by:

-concluding, where appropriate, agreements on a bilateral or multilateral basis, providing for the extension of relations among competent State institutions and non-governmental organizations in the field of culture, as well as among people engaged in cultural activities, taking into account the need both for flexibility and the fullest possible use of testing agreements, and bearing in mind that agreements and also other arrangements constitute important means of developing cultural co-operation and exchanges;

-contributing to the development of direct communication and co-operation among relevant State institutions and non-governmental organizations, including, where necessary, such communication and co-operation carried out on the basis of special agreements and arrangements;

-encouraging direct contacts and communications among persons engaged in cultural activities, including, where necessary, such contacts and communications carried out on the basis of special agreements and arrangements.

\section{Mutual Knowledge}

Within their competence to adopt, on a bilateral and multilateral level, appropriate measures which would give their peoples a more comprehensive and complete mutual knowledge of their achievements in the various fields of culture, and among them:

- to examine jointly, if necessary with the assistance of appropriate international organizations, the possible creation in Europe and the structure of a bank of cultural data, which would collect information from the participating countries and make it available to its correspondents on 


\section{THE HELSINKI PROCESS}

their request, and to convene for this purpose a meeting of experts from interested States;

-to consider, if necessary in conjunction with appropriate international organizations, ways of compiling in Europe an inventory of documentary films of a cultural or scientific nature from the participating States;

- to encourage more frequent book exhibitions and to examine the possibility of organizing periodically in Europe a large-scale exhibition of books from the participating States;

-to promote the systematic exchange, between the institutions concerned and publishing houses, of catalogues of available books as well as of pre-publication material which will include, as far as possible, all forthcoming publications; and also to promote the exchange of material between firms publishing encyclopedias, with a view to improving the presentation of each country;

- to examine jointly questions of expanding and improving exchanges of information in the various fields of culture, such as theater, music, library work as well as the conservation and restoration of cultural property.

\section{Exchanges and Dissemination}

To contribute to the improvement of facilities for exchanges and the dissemination of cultural property, by appropriate means, in particular by:

-studying the possibilities for harmonizing and reducing the charges relating to international commercial exchanges of books and other cultural materials, and also for new means of insuring works of art in foreign exhibitions and for reducing the risks of damage or loss to which these works are exposed by their movement;

-facilitating the formalities of customs clearance, in good time for programmes of artistic events, of the works 
of art, materials and accessories appearing on lists agreed upon by the organizers of these events;

-encouraging meetings among representatives of competent organizations and relevant firms to examine measures within their field of activity - such as the simplification of orders, time limits for sending supplies and modalities of payment-which might facilitate international commercial exchanges of books;

-promoting the loan and exchange of films among their film institutes and film libraries;

-encouraging the exchange of information among interested parties concerning events of a cultural character foreseen in the participating States, in fields where this is most appropriate, such as music, theatre and the plastic and graphic arts, with a view to contributing to the compilation and publication of a calendar of such events, with the assistance, where necessary, of the appropriate international organizations;

-encouraging a study of the impact which the foreseeable development, and a possible harmonization among interested parties, of the technical means used for the dissemination of culture might have on the development of cultural co-operation and exchanges, while keeping in view the preservation of the diversity and originality of their respective cultures;

-encouraging, in the way they deem appropriate, within their cultural policies, the further development of interest in the cultural heritage of the other participating States, conscious of the merits and the value of each culture;

-ndeavouring to ensure the full and effective application of the international agreements and conventions on copyrights and on circulation of cultural property to which they are party or to which they may decide in the future to become party. 
THE HELSINKI PROCESS

\section{Access}

To promote fuller mutual access by all to the achievements-works, experiences and performing arts-in the various fields of culture of their countries, and to that end to make the best possible efforts, in accordance with their competence, more particularly:

- to promote wider dissemination of books and artistic works, in particular by such means as:

facilitating, while taking full account of the international copyright conventions to which they are party, international contacts and communications between authors and publishing houses as well as other cultural institutions, with a view to a more complete mutual access to cultural achievements;

recommending that, in determining the size of editions, publishing houses take into account also the demand from the other participating States, and that rights of sale in other participating States be granted, where possible, to several sales organizations of the importing countries, by agreement between interested partners;

encouraging competent organizations and relevant firms to conclude agreements and contracts and contributing, by this means, to a gradual increase in the number and diversity of works by authors from the other participating States available in the original and in translation in their libraries and bookshops;

promoting, where deemed appropriate, an increase in the number of sales outlets where books by authors from the other participating States, imported in the original on the basis of agreements and contracts, and in translation, are for sale;

promoting, on a wider scale, the translation of works in the sphere of literature and other fields of cultural activity, produced in the languages of the other participating 
States, especially from the less widely spoken languages, and the publication and dissemination of the translated works by such measures as:

encouraging more regular contacts between interested publishing houses;

developing their efforts in the basic and advanced training of translators;

encouraging, by appropriate means, the publishing houses of their countries to publish translations;

facilitating the exchange between publishers and interested institutions of lists of books which might be translated;

promoting between their countries the professional activity and co-operation of translators;

carrying out joint studies on ways of further promoting translations and their dissemination;

improving and expanding exchanges of books, bibliographies and catalogue cards between libraries;

- to envisage other appropriate measures which would permit, where necessary by mutual agreement among interested parties, the facilitation of access to their respective cultural achievements, in particular in the field of books;

- to contribute by appropriate means to the wider use of the $n$ iss media in order to improve mutual acquaintance with the cultural life of each;

- to seek to develop the necessary conditions for migrant workers and their families to preserve their links with their national culture, and also to adapt themselves to their new cultural environment;

- to encourage the competent bodies and enterprises to make a wider choice and effect wider distribution of full-length and documentary films from the other participating States, and to promote more frequent non-commercial showings, such as premieres, film weeks and festivals, giving due consideration to films from countries whose cinematographic works are less well known; 
THE HELSINKI PROCESS

- to promote, by appropriate means, the extension of opportunities for specialists from the other participating States to work with materials of a cultural character from film and audio-visual archives, within the framework of the existing rules for work on such archival materials;

- to encourage a joint study by interested bodies, where appropriate with the assistance of the competent international organizations, of the expediency and the conditions for the establishment of a repertory of their recorded television programmes of a cultural nature, as well as of the means of viewing them rapidly in order to facilitate their selection and possible acquisition.

\section{Contacts and Co-operation}

To contribute, by appropriate means, to the development of contracts and co-operation in the various fields of culture, especially among creative artists and people engaged in cultural activities, in particular by making efforts to:

-promote for persons active in the field of culture, travel and meetings including, where necessary, those carried out on the basis of agreements, contracts or other special arrangements and which are relevant to their cultural cooperation;

-encourage in this way contacts among creative and performing artists and artistic groups with a view to their working together, making known their works in other participating States or exchanging views on topics relevant to their common activity;

-encourage, where necessary through appropriate arrangements, exchanges of trainees and specialists and the granting of scholarships for basic and advanced training in various fields of culture such as the arts and architecture, museums and libraries, literary studies and translation, and 
contribute to the creation of favourable conditions of reception in their respective institutions;

-encourage the exchange of experience in the training of organizers of cultural activities as well as of teachers and specialists in fields such as theatre, opera, ballet, music and fine arts;

-continue to encourage the organization of international meetings among creative artists, especially young creative artists, on current questions of artistic and literary creation which are of interest for joint study;

-study other possibilities for developing exchanges and co-operation among persons active in the field of culture, with a view to a better mutual knowledge of the cultural life of the participating States.

\section{Fields and Forms of Co-operation}

To encourage the search for new fields and forms of cultural co-operation, to these ends contributing to the conclusion among interested parties, where necessary, of appropriate agreements and arrangements, and in this context to promote:

-joint studies regarding cultural policies, in particular in their social aspects, and as they relate to planning, townplanning, educational and environmental policies, and the cultural aspects of tourism;

- the exchange of knowledge in the realm of cultural diversity, with a view to contributing thus to a better understanding by interested parties of such diversity where it occurs;

-the exchange of information, and as may be appropriate, meetings of experts, the elaboration and the execution of research programmes and projects, as well as their joint evaluation, and the dissemination of the results, on the subjects indicated above; 


\section{THE HELSINKI PROCESS}

-such forms of cultural co-operation and the development of such joint projects as:

international events in the fields of the plastic and graphic arts, cinema, theatre, ballet, music, folklore, etc.; book fairs and exhibitions, joint performances of operatic and dramatic works, as well as performances given by soloists, instrumental ensembles, orchestras, choirs and other artistic groups, including those composed of amateurs, paying due attention to the organization of international cultural youth events and the exchange of young artists;

the inclusion of works by writers and composers from the other participating States in the repertoires of soloists and artistic ensembles;

the preparation, translation and publication of articles, studies and monographs, as well as of low-cost books and of artistic and literary collections, suited to making better known respective cultural achievements, envisaging for this purpose meetings among experts and representatives of publishing houses;

the co-production and the exchange of films and of radio and television programmes, by promoting, in particular, meetings among producers, technicians and representatives of the public authorities with a view to working out favorable conditions for the execution of specific joint projects and by encouraging, in the field of co-production, the establishment of international filming teams;

the organization of competitions for architects and town-planners, bearing in mind the possible implementation of the best projects and ine formation, where possible, of international teams;

the implementation of joint projects for conserving, restoring and showing to advantage works of art, historical and archaeological monuments and sites of cultural interest, with the help, in appropriate cases, of international organizations of a governınental or non-governmental character as 
well as of private institutions-competent and active in these fields-envisaging for this purpose:

periodic meetings of experts of the interested parties to elaborate the necessary proposals, while bearing in mind the need to consider these questions in a wider social and economic context;

the publication in appropriate periodicals of articles designed to make known and to compare, among the participating States, the most significant achievements and innovations;

a joint study with a view to the improvement and possible harmonization of the different systems used to inventory and catalogue the historical monuments and places of cultural interest in their countries;

the study of the possibilities for organizing international courses for the training of specialists in different disciplines relating to restoration.

* * *

National minorities or regional cultures. The participating States, recognizing the contribution that national minorities or regional cultures can make to co-operation among them in various fields of culture, intend, when such minorities or cultures exist within their territory, to facilitate this contribution, taking into account the legitimate interests of their members.

\section{Co-operation and Exchanges in the Field of Education}

The participating States,

Conscious that the development of relations of an international character in the fields of education and science contributes to a better mutual understanding and is to the 


\section{THE HELSINKI PROCESS}

advantage of all peoples as well as to the benefit of future generations,

Prepared to facilitate, between organizations, institutions and persons engaged in education and science, the further development of exchanges of knowledge and experience as well as of contacts, on the basis of special arrangements where these are necessary,

Desiring to strengthen the links among educational and scientific establishments and also to encourage their cooperation in sectors of common interest, particularly where the levels of knowledge and resources require efforts to be concerted internationally, and

Convinced that progress in these fields should be accompanied and supported by a wider knowledge of foreign languages,

Express to these ends their intention in particular:

\section{(a) Extension of Relations}

To expand and improve at the various levels co-operation and links in the fields of education and science in particular by:

-concluding, where appropriate, bilateral or multilateral agreements providing for co-operation and exchanges among State institutions, non-governmental bodies and persons engaged in activities in education and science, bearing in mind the need both for flexibility and the fuller use of existing agreements and arrangements;

-promoting the conclusion of direct arrangements between universities and other institutions of higher education and research in the framework of agreements between governments : appropriate;

-encouraging among persons engaged in education and science direct contacts and communications, including those 
based on special agreements or arrangements where these are appropriate.

\section{(b) Access and Exchanges}

To improve access, under mutually acceptable conditions, for students, teachers and scholars of the participating States to each other's educational, cultural and scientific institutions, and to intensify exchanges among these institutions in all areas of common interest, in particular by:

-increasing the exchange of information on facilities for study and courses open to foreign participants, as well as on the conditions under which they will be admitted and received;

-faciltating travel between the participating States by scholars, teachers and students for purposes of study, teaching and research as well as for improving knowledge of each other's educational, cultural and scientific achievements;

-encouraging the award of scholarships for study, teaching and research in their countries to scholars, teachers and students of other participating States;

-establishing, developing or encouraging programmes providing for the broader exchange of scholars, teachers and students, including the organization of symposia, seminars and collaborative projects, and the exchanges of educational and scholarly information such as university publications and materials from libraries;

-promoting the efficient implementation of such arrangements and programmes by providing scholars, teachers and students in good time with more detailed information about their placing in universities and institutes and the programmes envisaged for them; by granting them the opportunity to use relevant scholarly, scientific and open archival materials; and by facilitating their travel within the re- 


\section{THE HELSINKI PROCESS}

ceiving State for the purpose of study or research as well as in the form of vacation tours on the basis of the usual procedures;

-promoting a more exact assessment of the problems of comparison and equivalence of academic degrees and diplomas by fostering the exchange of information on the organization, duration and content of studies, the comparison of methods of assessing levels of knowledge and academic qualifications, and, where feasible, arriving at the mutual recognition of academic degrees and diplomas either through governmental agreements, where necessary or direct arrangements between universities and other institutions of higher learning and research;

-recommending, moreover, to the appropriate international organizations that they should intensify their efforts to reach a generally acceptable solution to the problems of comparison and equivalence between academic degrees and diplomas.

\section{(c) Science}

Within their competence to broaden and improve cooperation and exchanges in the field of science, in particular:

To increase, on a bilateral or multilateral basis, the exchange and dissemination of scientific information and documentation by such means as:

-making this information more widely available to scientists and research workers of the other participating States through, for instance, participation in international information-sharing programmes or through other appropriate arrangements;

-broadening and facilitating the exchange of samples and other scientific materials used particularly for fundamental research in the fields of natural sciences and medicine; 
-inviting scientific institutions and universities to keep each other more fully and regularly informed about their current and contemplated research work in fields of common interest.

To facilitate the extension of communications and direct contacts between universities, scientific institutions and associations as well as among scientists and research workers, including those based where necessary on special agreements or arrangements, by such means as:

-further developing exchanges of scientists and research workers and encouraging the organization of preparatory meetings or working groups on research topics of common interest;

-encouraging the creation of joint teams of scientists to pursue research projects under arrangements made by the scientific institutions of several countries;

-assisting the organization and successful functioning of international conferences and seminars and participation in them by their scientists and research workers;

-furthermore envisaging, in the near future, a "Scientific Forum" in the form of a meeting of leading personalities in science from the participating States to discuss interrelated problems of common interest concerning current and future developments in science, and to promote the expansion of contacts, communications and the exchange of information between scientific institutions and among scientists;

- foreseeing, at an early date, a meeting of experts representing the participating States and their national scientific institutions, in order to prepare such a "Scientific Forum" in consultation with appropriate international organizations, such as UNESCO and the ECE;

-considering in due course what further steps might be taken with respect to the "Scientific Forum".

To develop in the field of scientific research, on a bilateral or multilateral basis, the co-ordination of pro- 


\section{THE HELSINKI PROCESS}

grammes carried out in the participating States and the organization of joint programmes, especially in the areas mentioned below, which may involve the combined efforts of scientists and in certain cases the use of costly or unique equipment. The list of subjects in these areas is illustrative; and specific projects would have to be determined subsequently by the potential partners in the participating States, taking account of the contribution which could be made by appropriate international organizations and scientific institutions:

-exact and natural sciences, in particular fundamental research in such fields as mathematics, phy : $s$, theoretical physics, geophysics, chemistry, biology, ecology and astronomy;

-medicine, in particular basic research into cancer and cardiovascular diseases, studies on the diseases endemic in the developing countries, as well as medico-social research with special emphasis on occupational diseases, the rehabilitation of the handicapped and the care of mothers, children and the elderly;

-the humanities and social sciences, such as history, geography, philosophy, psychology, pedagogical research, linguistics, sociology, the legal, political and economic sciences; comparative studies on social, socio-economic and cultural phenomena which are of common interest to the participating States, especially the problems of human environment and urban development; and scientific studies on the methods of conserving and restoring monuments and works of art.

\section{(d) Foreign Languages and Civilizations}

To encourage the study of foreign languages and civilizations as an important means of expanding communication among peoples for their better acquaintance with the culture 
of each country, as well as for the strengthening of international co-operation; to this end to stimulate, within their competence, the further development and improvement of foreign language teaching and the diversification of choice of languages taught at various levels, paying due attention to less widely spread or studied languages, and in particular:

- to intensify co-operation aimed at improving the teaching of foreign languages through exchanges of information and experience concerning the development and application of effective modern teaching methods and technical aids, adapted to the needs of different categories of students, including methods of accelerated teaching; and to consider the possibility of conducting, on a bilateral or multilateral basis, studies of new methods of foreign language teaching;

- to encourage co-operation between institutions concerned, on a bilateral or multilateral basis, aimed at exploiting more fully the resources of modern educational technology in language teaching, for example through comparative studies by their specialists and, where agreed, through exchanges or transfers of audio-visual materials, of materials used for preparing textbooks, as well as of information about new types of technical equipment used for teaching languages;

- to promote the exchange of information on the experience acquired in the training of language teachers and to intensify exchanges on a bilateral basis of language teachers and students as well as to facilitate their participation in summer courses in languages and civilizations, wherever these are organized;

-to encourage co-operation among experts in the field of lexicography with the aim of defining the necessary terminological equivalents, particularly in the scientific and technical disciplines, in order to facilitate relations among scientific institutions and specialists;

-to promote the wider spread of foreign language study among the different types of secondary education es- 


\section{THE HELSINKI PROCESS}

tablishments and greater possibilities of choice between an increased number of European languages; and in this context to consider, wherever appropriate, the possibilities for developing the recruitment and training of teachers as well as the organization of the student groups required;

- to favour, in higher education, a wider choice in the languages offered to language students and greater opportunities for other students to study various foreign languages; also to facilitate, where desirable, the organization of courses in languages and civilizations, on the basis of special arrangements as necessary, to be given by foreign lecturers, particularly from European countries having less widely spread or studied languages;

- to promote, within the framework of adult education, the further development of specialized programmes, adapted to various needs and interests, for teaching foreign languages to their own inhabitants and the languages of host countries to interested adults from other countries; in this context to encourage interested institutions to cooperate, for example, in the elaboration of programmes for teaching by radio and television and by accelerated methods, and also, where desirable, in the definition of study objectives for such programmes, with a view to arriving at comparable levels of language proficiency;

-to encourage the association, where appropriate, of the teaching of foreign languages with the study of the corresponding civilizations and also to make further efforts to stimulate interest in the study of foreign languages, including relevant out-of-class activities.

\section{(e) Teaching Methods}

To promote the exchange of experience, on a bilateral or multilateral basis, in teaching methods at all levels of education, including those used in permanent and adult edu- 
cation, as well as the exchar.ge of teaching materials, in particular by:

-further developing various forms of contacts and cooperation in the different fields of pedagogical science, for example through comparative or joint studies carried out by interested institutions or through exchanges of information on the results of teaching experiments;

-intensifying exchanges of information on teaching methods used in various educational systems and on results of research into the processes by which pupils and students acquire knowledge, taking account of relevant experience in different types of specialized education;

- facilitating exchanges of experience concerning the organization and functioning of education intended for adults and recurrent education, the relationships between these and other forms and levels of education, as well as concerning the means of adapting education, including vocational and technical training, to the needs of economic and social development in their countries;

-encouraging exchanges of experience in the education of youth and adults in international understanding, with particular reference to those major problems of mankind whose solution calls for a common approach and wider international co-operation;

-encouraging exchanges of teaching materials-including school textbooks, having in mind the possibility of promoting mutual knowledge and facilitating the presentation of each country in such books-as well as exchanges of information on technical innovations in the field of education.

$$
\text { *** }
$$

National minorities or regional cultures. The participating States, recognizing the contribution that national minorities or regional cultures can make to co-operation among them in various fields of education, intend, when such mi- 


\section{THE HELSINKI PROCESS}

norities or cultures exist within their territory, to facilitate this contribution, taking into account the legitimate interests of their members.

\section{FOLLOW-UP TO THE CONFERENCE}

The participating States,

Having considered and evaluated the progress made at the Conference on Security and Co-operation in Europe,-

Considering further that, within the broader context of the world, the Conference is an important part of the process of improving security and developing co-opration in Europe and that its results will contribute significantly to this process,

Intending to implement the provisions of the Final Act of the Conference in order to give full effect to its results and thus to further the process of improving security and developing co-operation in Europe,

Convinced that, in order to achieve the aims sought by the Conference, they should make further unilateral, bilateral and multilateral efforts and continue, in the appropriate forms set forth below, the multilateral process initiated by the Conference,

1. Declare their resolve, in the period following the Conference, to pay due regard to and implement the provisions of the Final Act of the Conference:

(a) unilaterally, in all cases which lend themselves to such action;

(b) bilaterally, by negotiations with other participating States;

(c) multilaterally, by meetings of experts of the participating States, and also within the framework of existing international organizations, such as the United Nations Econımic Commission for Europe and UNESCO, with regard to educational, scientific and cultural co-operation; 
2. Declare furthermore their resolve to continue the multilateral process initiated by the Conference:

(a) by proceeding to a thorough exchange of views both on the implementation of the provisions of the Final Act and of the tasks defined by the Conference, as well as, in the context of the questions dealt with by the latter, or the deepening of their mutual relations, the improvement of security and the development of co-operation in Europe, and the development of the process of detente in the future;

(b) by organizing to these ends meetings among their representatives, beginning with a meeting at the level of representatives appointed by the Ministers of Foreign Affairs. This meeting will define the appropriate modalities for the holding of other meetings which could include further similar meetings and the possibility of a new Conference;

3. The first of the meetings indicated above will be held at Belgrade in 1977. A preparatory meeting to organize this meeting will be held at Belgrade on 15 June 1977. The preparatory meeting will decide on the date, duration, agenda and other modalities of the meeting of representatives appointed by the Ministers of Foreign Affairs;

4. The rules of procedure, the working methods and the scale of distribution for the expenses of the Conference will, mutatis mutandis, be applied to the meetings envisaged in paragraphs 1 (c), 2 and 3 above. All the above-mentioned meetings will be held in the participating States in rotation. The services of a technical secretariat will be provided by the host country.

The original of this Final Act, drawn up in English, French, German, Italian, Russian and Spanish, will be transmitted to the Government of the Republic of Finland, which will retain it in its archives. Each of the participating States will receive from the Government of the Republic of Finland a true copy of this Final Act. 


\section{THE HELSINKI PROCESS}

The text of this Final Act will be published in each participating State, which will disseminate it and make it known as widely as possible.

The Government of the Republic of Finland is requested to transmit to the Secretary-General of the United Nations the text of this Final Act, which is not eligible for registration under Article 102 of the Charter of the United Nations, with a view to its circulation to all the members of the Organization as an official document of the United Nations. ${ }^{1}$

The Government of the Republic of Finland is also requested to transmit the text of this Final Act to the Director-General of UNESCO and to the Executive Secretary of the United Nations Economic Commission for Europe.

Wherefore, the undersigned High Representatives of the participating States, mindful of the high political significance which they attach to the results of the Conference, and declaring their determination to act in accordance with the

1 Journal no. $80 /$ bis of the Co-ordinating Committee of the Conference on Security and Cooperation in Europe, July 18, 1975, reported that the delegate of Finland had on that day informed the committee of the intention of his government to send the following letter to the Secretary General of the United Nations:

"SIR, I have the honour to inform you that the High Representatives of the States participating in the Conference on Security and Co-operation in Europe have requested the Government of the Republic of Finland to transmit to you the text of the Final Act of the Conference signed at Helsinki on [1 August 1975].

"I have also been asked to request you, Mr. Secretary-General, to arrange for the circulation of this Final Act to Member States of the Organization as an official document of the United Nations, and to draw your attention to the fact that this Final Act is not eligible, in whole or in part, for registration with the Secretariat under Article 102 of the Charter of the United Nations, as would be the case were it a matter of a treaty or international agreement, under the aforesaid Article.

"Accept, Sir, the assurance of my highest consideration." 
provisions contained in the above texts, have subscribed their signatures below:2

The Federal Republic of Germany: HELMUT SCHMIDT, Federal Chancellor

The German Democratic Republic:

ERICH HONECKER, First Secretary of the Central Committee of the Socialist Unity Party of Germany

The United States of America:

GERALD R. FORD, President of the United States of America

The Republic of Austria:

BRUNO KREISKY, Federal Chancellor

The Kingdom of Belgium:

Leo Tindemans, Prime Minister

The People's Republic of Bulgaria:

TODOR JIVKov, First Secretary, Central Committee of the Communist Party of Bulgaria and President of the Council of State of the People's Republic of Bulgaria

Canada:

Pierre Elliott Trudeau, Prime Minister

The Republic of Cyprus:

His Beatitude ARChBishor MaKarios III, President of the Republic of Cyprus

Denmark:

ANKER JORGENSEN, Prime Minister

Spain:

Carlos Arias Navarro, Head of the Government

The Republic of Finland:

Urho KeKKonen, President of the Republic

2 The final act was signed in alphabetical order according to the French spelling of the names of the countries. 


\section{THE HELSINKI PROCESS}

The French Republic:

VALERY GISCARD D'ESTAING

The United Kingdom of Great Britain and Northern Ireland:

The Rt. Hon. HaRold WILSON, O.B.E., M.P., F.R.S., First Lord of the Treasury and Prime Minister of the United Kingdom of Great Britain and Northern Ireland

The Hellenic Republic:

Constantin Caramanlis, Prime Minister

The Hungarian People's Republic:

JANOS KADAR, First Secretary of the Central Committee of the Hungarian Socialist Workers' Party, Member of the Presidential Council of the Hungarian People's Republic

Ireland:

Liam Cosgrave, Prime Minister

Iceland:

Geir Hallgrimsson, Prime Minister

The Italian Republic:

ALDO MORO, Prime Minister of the Italian Republic and in his capacity as President in office of the Council of the European Communities

The Principality of Liechtenstein:

WALTER KIEBER, Head of Government

The Grand Duchy of Luxembourg:

GASTON THORN, Prime Minister, Minister for Foreign Affairs

The Republic of Malta:

Dom Mintoff, Prime Minister, Minister for Commonwealth and Foreign Affairs

The Principality of Monaco:

ANDRe SAINT-MLeuX, Minister of State, President of the Government Council, Representing H.S.H. the Prince of Monaco 
THE FINAL ACT

Norway:

Trygve Bratteli, Prime Minister

The Kingdom of the Netherlands:

J.M. DEN UYL, Prime Minister

Polish People's Republic:

EDWARD GIEREK, First Secretary of the Central Committee of the Polish United Worker's Party

Portugal:

FRANCISCo Da Costa Gomes, President of the Republic

The Socialist Republic of Romania:

Nicolae Ceausescu, President of the Socialist Republic of Romania

San Marino:

Gian LUIGI BerTI, Secretary of State for Foreign and Political Affairs

The Holy See:

Son Excellence Monseigneur Agostino CASAROLI, Secretary of the Council for Church Public Affairs, Special Delegate of His Holiness Pope Paul VI

Sweden:

Olof PAlME, Prime Minister

The Swiss Confederation:

PIERRE GRABER, President of the Confederation, Head of the Federal Political Department

The Czechoslovak Socialist Republic:

GUSTAV HUSAK, Secretary-General of the Communist Party of Czechoslovakia and President of the Czechoslovak Socialist Republic

The Republic of Turkey:

Suleyman Demirel, Prime Minister

The Union of Soviet Socialist Republics:

L. BRENEV, General Secretary of the CC of the CPSU 


\section{THE HELSINKI PROCESS}

The Socialist Federal Republic of Jugoslavia:

JosIP BROZ TrTo, President of the Socialist Federal Republic of Jugoslavia 


\section{Appendix C The Madrid Concluding Document}

1. The representatives of the participating States of the Conference on Security and Co-operation in Europe met in Madrid from 11 November 1980 to 9 September 1983 in accordance with the provisions of the Final Act relating to the Follow-up to the Conference, as well as the basis of the other relevant documents adopted during the process of the CSCE.

2. The participants were addressed on 12 November 1980 by the Spanish Prime Minister.

3. Opening statements were made by all Heads of Delegations among whom were Ministers and Deputy Ministers of Foreign Affairs of a number of participating States. Some Ministers of Foreign Affairs addressed the Meeting also at later stages.

4. Contributions were made by representatives of the United Nations Economic Commission for Europe (ECE) and UNESCO.

Contributions were also made by the following nonparticipating Mediterranean States: Algeria, Egypt, Israel, Morocco and Tunisia.

5. The representatives of the participating States stressed the high political significance of the Conference on Security and Co-operation in Europe and of the process initiated by it as well as of the ways and means it provides for States to further their efforts to increase security, develop co-operation and enhance mutual understanding in Europe. They therefore reaffirmed their commitment to the process of the CSCE and emphasized the importance of the implementation of all the provisions and the respect for all the 


\section{THE HELSINKI PROCESS}

principles of the Final Act by each of them as being essential for the development of this process. Furthermore, they stressed the importance they attach to security and genuine detente, while deploring the deterioration of the international situation since the Belgrade Meeting 1977.

Accordingly, the participating States agreed that renewed efforts should be made to give full effect to the Final Act through concrete action, unilateral, bilateral and multilateral, in order to restore trust and confidence between the participating States which would permit a substantial improvement in their mutual relations. They considered that the future of the CSCE process required balanced progress in all sections of the Final Act.

6. In accordance with the mandate provided for in the Final Act and the Agenda of the Madrid Meeting, the representatives of the participating States held a thorough exchange of views both on the implementation of the provisions of the Final Act and of the tasks defined by the Conference, as well as, in the context of the questions dealt with by the latter, on the deepening of their mutual relations, the improvement of security and the development of co-operation in Europe, and the development of the process of détente in the future.

7. It was confirmed that the thorough exchange of views constitutes in itself a valuable contribution toward the achievement of the aims set by the CSCE. In this context, it was agreed that these aims can only be attained by continuous implementation, unilaterally, bilaterally and multilaterally, of all the provisions and by respect for all the principles of the Final Act.

8. During this exchange of views, different and at times contradictory opinions were expressed as to the degree of implementation of the Final Act reached so far by paricipating States. While certain progress was noted, concern was expressed at the serious deficiencies in the implementation of this document. 
9. Critical assessments from different viewpoints were given as to the application of and respect for the principles of the Final Act. Serious violations of a number of these principles were deplored during these assessments. Therefore, the participating States, at times represented at a higher level, considered it necessary to state, at various stages of the Meeting, that strict application of and respect for these principles, in all their aspects, are essential for the improvement of mutual relations between the participating States.

The necessity was also stressed that the relations of the participating States with all other States should be conducted in the spirit of the principles.

10. Concern was expressed about the continued lack of confidence among participating States.

Concern was also expressed as to the spread of terrorism.

11. The implementation of the provisions of the Final Act concerning Confidence-Building Measures, Co-operation in the field of Economics, of Science and Technology and of Environment, as well as Co-operation in Humanitarian and other fields was thoroughly discussed. It was considered that the numercus possibilities offered by the Final Act had not been sufficiently utilized. Questions relating to Security and Co-operation in the Mediterranean were also discussed.

12. The participating States reaffirmed their commitment to the continuation of the CSCE process as agreed to in the chapter on the Follow-up to the Conference contained in the Final Act.

13. The representatives of the participating States took note of the reports of the meetings of experts and of the "Scientific Fonum", and in the course of their deliberations took the results of these meetings into account. 


\section{THE HELSINKI PROCESS}

14. The representatives of the participating States examined all the proposals submitted concerning the above ques tions and agreed on the following:

\section{QUESTIONS RELATING TO SE'URITY IN EUROPE}

The participating States express their determination

- to exert new efforts to make détente an effective, as well as continuing increasingly viable and comprehensive process, universal in scope, as undertaken under the Final Act;

- to seek solutions to outstanding problems through peaceful means;

- to fulfill consistently all the provisions under the Final Ac: and, in particular, strictly and unreservedly to respect and put into practice all the ten principles contained in the Declaration of Principles Guiding Relations between Participating States, irrespective of their political, economic or social systems, as well as of their size, geographical location or level of economic development, including their commitment to corduct their relations with all other States in the spirit of these principles;

- to develop relations of mutual co-operation, friendship and confidence, refraining from any action which, being contrary to the Final Act, might impair such relations;

- to encourage genuine efforts to implement the Final Act;

- to exert genuine efforts toward containing an increasing arms build-up as well as toward strengthening confidence and security and promoting disarmament. 
THE MADRID CONCLUDING DOCUMENT

\section{Principles}

1. They reaffirm their determination fully to respect and apply these principles and accordingly, to promote by all means, both in law and practice, their increased effectiveness. They consider that one such means could be to give legislative expression-in forms appropriate to practices and procedures specific to each country-to the ten principles set forth in the Final Act.

2. They recognize it as important that treaties and agreements concluded by participating States reflect and be consonant with the relevant principles and, where appropriate, refer to them.

3. The partic pating States reaffirm the need that refraining from the threat or use of force, as a norm of international life, should be strictly and effectively observed. To this end they stress their duty, under the relevant provisions of the Final Act, to act accordingly.

4. The participating States condemn terrorism, including terrorism in international relations, as endangering or taking innocent human lives or otherwise jeopardizing human rights and fundamental freedoms, and emphasize the necessity to take resolute measures to combat it. They express their determination to take effective measures for the prevention and suppression of acts of terrorism, both at the national level and through international co-operation including appropriate bilateral and multilateral agreements, and accordingly to broaden and reinforce mutual co-operation to combat such acts. They agree to do so in conformity with the Charter of the United Nations, the United Nations Declaration on Principles of International Law concerning Friendly Relations and Co-operation among States and the Helsinki Final Act.

5. In the context of the combat against acts of terrorism. they will take all appropriate measures in preventing their respective territories from being used for the preparation. 


\section{THE HELSINKI PROCESS}

organization or commission of terrorist activities, including those directed against other participating States and their citizens. This also includes measures to prohibit on their territories illegal activities of persons, groups or organizations that instigate, organize or engage in the perpetration of acts of terrorism.

6. The participating States confirm that they will refrain from direct or indirect assistance to terrorist activities or to subversive or other activities directed towards the violent overthrow of the regime of another participating State. Accordingly, they will refrain, inter alia, from financing, encouraging, fomenting or tolerating any such activities.

7. They express their determination to do their utmost to assure necessary security to all official representatives and persons who participate on their territories in activities within the scope of diplomatic, consular or other official relations.

8. They emphasize that all the participating States recognize in the Final Act the universal significance of human rights and fundamental freedoms, respect for which is an essential factor for the peace, justice and well-being necessary to ensure the development of friendly relations and co-operation among themselves, as among all States.

9. The participating States stress their determination to promote and encourage the effective exercise of human rights and fundamental freedoms, all of which derive from the inherent dignity of the human person and are essential for his free and full development, and to assure constant and tangible progress in accordance with the Final Act, aiming at further and steady development in this field in all participating States, irrespective of their political, economic and social systems.

They similarly stress their determination to develop their laws and regulations in the field of civil, political, economic, social, cultural and other human rights and fun- 
damental freedoms; they also emphasize their determination to ensure the effective exercise of these rights and freedoms.

They recall the right of the individual to know and act upon his rights and duties in the field of human rights and fundamental freedoms, as embodied in the Final Act, and will take the necessary action in their respective countries to effectively ensure this right.

10. The participating States reaffirm that they will recognize, respect and furthermore agree to take the action necessary to ensure the freedom of the individual to profess and practise, alone or in community with others, religion or belief acting in accordance with the dictates of his own conscience.

In this context, they will consult, whenever necessary, the religious faiths, institutions and organizations, which act within the constitutional framework of their respective countries.

They will favourably consider applications by religious communities of believers practising or prepared to practise their faith within the constitutional framework of their States, to be granted the status provided for in their respective countries for religious faiths, institutions and organizations.

11. They stress also the importance of constant progress in ensuring the respect for and actual enjoyment of the rights of persons belonging to national minorities as well as protecting their legitimate interests as provided for in the Final Act.

12. They stress the importance of ensuring equal rights of men and women; accordingly, they agree to take all actions necessary to promote equally effective participation of men and women in political, economic, and social and cultural life.

13. The participating States will ensure the right of workers freely to establish and join trade unions, the right of trade unions freely to exercise their activities and other 


\section{THE HELSINKI PROCESS}

rights as laid down in relevant international instruments. They note that these rights will be exercised in compliance with the law of the State and in conformity with the State's obligations under international law. They will encourage, as appropriate, direct contacts and communication among such trade unions and their representatives.

14. They reaffirm that governments, institutions, organizations and persons have a relevant and positive role to play in contributing towards the achievement of the abovementioned aims of their co-operation.

15. They reaffirm the particular significance of the Universal Declaration of Human Rights, the International Covenants on Human Rights and other relevant international instruments of their joint and separate efforts to stimulate and develop universal respect for human rights and fundamental freedoms; they call on all participating States to act in conformity with those international instruments and on those participating States, which have not yet done so, to consider the possibility of acceding to the covenants.

16. They agree to give favourable consideration to the use of bilateral round-table meetings, held on a voluntary basis, between delegations composed by each participating State to discuss issues of human rights and fundamental freedoms in accordance with an agreed agenda in a spirit of mutual respect with a view to achieving greater understanding and co-operation based on the provisions of the Final Act.

17. They decide to convene a meeting of experts of the participating States on questions concerning respect, in their States, for human rights and fundamental freedoms, in all aspects, as embodied in the Final Act.

Upon invitation of the Government of Canada, the meeting of experts will be held in Ottawa, beginning on 7 May 1985. It will draw up conclusions and recommendations to be submitted to the governments of all participating States. 
THE MADRID CONCLUDING DOCUMENT

The meeting will be preceded by a preparatory meeting which will be held in Ottawa upon the invitation of the Government of Canada, starting on 23 April 1985.

18. In conformity with the recommendation contained in the Report of the Montreux Meeting of Experts, another meeting of experts of the participating States will be convened, at the invitation of the Government of Greece. it will take place in Athens and will commence on 21 March 1984, with the purpose of pursuing, on the basis of the Final Act, the examination of a generally acceptable method for the peaceful settlement of disputes aimed at complementing existing methods. The meeting will take into account the common approach set forth in the above-mentioned report.

19. Recalling the right of any participating State to belong or not to belong to international organizations, to be or not to be a party to bilateral or multilateral treaties including the right to be or not to be a party to treaties of alliance. and also the right to neutrality, the participating States take note of the declaration of the Government of the Republic of Malta in which it stated that, as an effective contribution to détente, peace and security in the Mediterranean region, the Republic of Malta is a neutral State adhering to a policy of non-alignment. They call upon all States to respect that declaration.

\section{Conference on Confidence- and Security- building Measures and Disarmament in Europe}

The participating States,

Recalling the provisions of the Final Act according to which they recognize the interest of all of them in efforts aimed at lessening military confrontation and promoting disarmament. 


\section{THE HELSINKI PROCESS}

Have agreed to convene a Conference on Confidenceand Security-building Measures and Disarmament in Europe.

1. The aim of the Conference is, as a substantial and integral part of the multilateral process initiated by the Conference on Security and Co-operation in Europe, with the participation of all the States signatories of the Final Act, to undertake, in stages, new, effective and concrete actions designed to make progress in strengthening confidence and security and in achieving disarmament, so as to give effect and expression to the duty of States to refrain from the threat or use of force in their mutual relations.

2. Thus the Conference will begin a process of which the first stage will be devoted to the negotiation and adoption of a set of mutually complementary confidence- and security-building measures designed to reduce the risk of military confrontation in Europe.

3. The first stage of the Conference will be held in Stockholm commencing on 17 January 1984.

4. On the basis of equality of right, balance and reciprocity, equal respect for the security interest of all CSCE participating States, and of their respective obligations concerning confidence- and security-building measures and disarmament in Europe, these confidence- and security-building measures will cover the whole as well as the adjoining sea $\operatorname{area}^{2}$ and air space. They will be of military significance and politically binding and will be provided with adequate forms of verification which correspond to their content.

As far as the adjoining sea area 2 and air space is concerned, the measures will be applicable to the military activities of all the participating States taking place there whenever these activities affect security in Europe as well as constitute a part of activities taking place within the whole of Europe as referred to above, which they will agree to notify. Necessary specifications will be made through the negotiations on the confidence- and securitybuilding measures at the Conference. 
THE MADRID CONCLUDING DOCUMENT

Nothing in the definition of the zone given above will diminish obligations already undertaken under the Final Act. The confidence- and security-building measures to be agreed upon at the Conference will also be applicable in all areas covered by any of the provisions in the Final Act relating to confidence-building measures and certain aspects of security and disarmament.

The provisions established by the negotiators will come into force in the forms and according to the procedure to be agreed upon by the Conference.

5. Taking into account the above-mentioned aim of the Conference, the next follow-up meeting of the participating States of the CSCE, to be held in Vienna, commencing on 4 November 1986, will assess the progress achieved during the first stage of the Conference.

6. Taking into account the relevant provisions of the Final Act, and having reviewed the results achieved by the first stage of the Conference, and also in the light of other relevant negotiations on security and disarmament affecting Europe, a future CSCE follow-up meeting will consider ways and appropriate means for the participating States to continue their efforts for security and disarmament in Europe, including the question of supplementing the present mandate for the next stage of the Conference on Confidence- and Security-building Measures and Disarmament in Europe.

7. A preparatory meeting, charged with establishing the agenda, time-table and other organizational modalities for the first stage of the Conference, will be held in Helsinki, commencing on 25 October 1983. Its duration shall not exceed three weeks.

8. The rules of procedure, the working methods and the scaie of distribution for the expenses valid for the CSCE will, mutatis mutandis, be applied to the Conference and to the preparatory meeting referred to in the preceding para- 


\section{THE HELSINKI PROCESS}

graph. The services of a technical secretariat will be provided by the host country.

\section{CO-OPERATION IN THE FIELD OF ECONOMICS, OF SCIENCE AND TECHNOLOGY AND OF THE ENVIRONMENT}

1. The participating States consider that the implementation of all provisions of the Final Act and full respect for the principles guiding relations among them set out therein are an essential basis for the development of cooperation among them in the field of economics, of science and technology and of the environment. At the same time they reaffirm their conviction that co-operation in these fields contributes to the reinforcement of peace and security in Europe and in the world as a whole. In this spirit they reiterate their resolve to pursue and intensify such cooperation between one another, irrespective of their economic and social systems.

2. The participatirg States confirm their interest in promoting adequate, favourable conditions in order further to develop trade and industrial co-operation among them, in particular by fully implementing all provisions of the second chapter of the Final Act, so as to make greater use of the possibilities created by their economic, scientific and technical potential. In this context and taking into consideration the efforts already made unilaterally, bilaterally and multilaterally in order to overcome a'l kinds of obstacles to trade, they reaffirm their intention to make further efforts aimed at reducing or progressively eliminating all kinds of obstacles to the development of trade.

Taking account of the activities of the United Nations Economic Commission for Europe (ECE) already carried 
THE MADRID CONCLUDING DOCUMENT

out in the field of all kinds of obstacles to trade, they recommend that further work on this subject be directed in particular towards identifying these obstacles and examining them with a view to finding means for their reduction or progressive elimination, in order to contribute to harmonious development of their economic relations.

3. On the basis of the provisions of the Final Act concerning business contracts and facilities the participating States declare their intention to make efforts to enable business negotiations and activities to be carried out more efficiently and expeditiously and further to create conditions facilitating closer contacts between representatives and experts of seller firms on the other hand and buyer as well as user firms on the other at all stages of transaction. They will also further other forms of operational contacts between sellers and users such as the holding of technical symposia and demonstrations and after-sales training or requalification courses for technical staff of user firms and organizations.

They also agree to take measures further to develop and improve facilities and working conditions for representatives of foreign firms and organizations on their territory, including telecommunications facilities for representatives of such firms and organizations, as well as to develop these and other amenities for temporarily resident staff including particular site personnel. They will endeavour further to take measures to speed up as far as possible procedures for the registration of foreign firms' representations and offices as well as for granting entry visas to business representatives.

4. The participating States declare their intention to ensure the regular publication and dissemination, as rapidly as possible, of economic and commercial information compiled in such a way as to facilitate the appreciation of market opportunities and thus to contribute effectively to the process of development international trade and industrial co-operation. 


\section{THE HELSINKI PROCESS}

To this end and in order to make further progress in achieving the aims laid down in the relevant provisions of the Final Act they intend to intensify their efforts to improve the comparability, comprehensiveness and clarity of their economic and commercial statistics, in particular by adopting where necessary the following measures: by accompanying their economic and trade statistics by adequately defined summary indices based wherever possible on constant values; by publishing their interim statistics whenever technically possible at least on a quarterly basis; by publishing their statistical compilations in sufficient detail to achieve the aims referred to above, in particular by using for their foreign trade statistics a product breakdown permitting the identification of particular products for purposes of market analysis; by striving to have their economic and trade statistics no less comprehensive than those previously published by the State concerned.

They further express their willingness to co-operate towards the early completion of work in the appropriate United Nations bodies on the harmonization and alignment of statistical nomenclatures.

The participating States further recognize the usefulness of making economic and commercial information existing in other participating States readily available to enterprises and firms in their countries through appropriate channels.

5. The participating States, conscious of the need further to improve the conditions conducive to a more efficient functioning of institutions and firms acting in the field of marketing, will promote a more active exchange of knowledge and techniques required for effective marketing, and will encourage more intensive relations among such institutions and firms. They agree to make full use of the possibilities offered by the ECE to further their co-operation in this field.

6. The participating States note the increasing frequency in the economic relations of compensation in all their forms. 
They recognize that a useful role can be played by such transactions, concluded on a mutually acceptable basis. At the same time they recognize that problems can be created by the linkage in such transactions between purchases and sales.

Taking account of the studies of the ECE already carried out in this field, they recommend that further work on this subject be directed in particular towards identifying such problems and examining ways of solving them in order to contribute to harmonious development of their economic relations.

7. The participating States recognize that the expansion of industrial co-operation, on the basis of their mutual interest and motivated by economic considerations. can contribute to the further development and diversification of their economic relations and to a wider utilization of modern technology.

They note the useful role bilateral agreements on economic, industrial and technical co-operation, including where appropriate, those of a long-term nature can play. They also express their willingness to promote favourable conditions for the development of industrial co-operation among competent organizations, enterprises and firms. To this end and with a view to facilitating the identification of new possibilities for industrial co-operation projects they recognize the desirability of further developing and improving the conditions for business activities and the exchange of economic and commercial information among competent organizations, enterprises and firm including small- and medium-sized enterprises.

They also note that, if it is in the mutual interest of potential partners, new forms of industrial co-operation can be envisaged, including those with organizations, institutions and firms of third countries.

They recommend that the ECE pursue and continue to pay particular attention to its activities in the field of 


\section{THE HELSINKI PROCESS}

industrial co-operation, inter alia by further directing its efforts towards examining ways of promoting tavorable conditions for the development of co-operation in this field, including the organization of symposia and seminars.

8. The participating States declare their readiness to continue their efforts aiming at a wider participation by small- and medium-size enterprises in trade and industrial co-operating. Aware of the problems particularly affecting such enterprises, the participating States will endeavour further to improve the conditions dealt with in the preceding paragraphs in order to facilitate the operations of these enterprises in the above-mentioned fields. The participating States further recommend that the ECE develop its special studies pertaining to these problems.

9. The participating States recognize the increasing importance of co-operation in the field of energy, inter alia that of a long-term natuie, on both a bilateral and multilateral basis. Welcoming the results so far achieved through such endeavours and in particular the work carried out hy the ECE they express their support for continuing the cooperation pursued by the Senior Advisers to ECE Governments on Energy aiming at the fulfillment of all parts of their mandate.

10. The participating States reaffirm their interest in reducing and preventing technical barriers to trade and welcome the increased co-operation in this field, inter alia the work of the Government Officials Responsible for Standardization Policies in the ECE. They will encourage the conclusion of international certification arrangements covering where appropriate the mutual acceptance of certification systems providing mutually satisfactory guarantees.

11. The participating States recommend that appropriate action be taken in ordei to facilitate the use and enlarge the scope of arbitration as an instrument for settling disputes in international trade and industrial co-operation. They recommend in particular the application of the provisions of 
THE MADRID CONCLUDING DOCUMENT

the United Nations Convention on Recognition and Enforcement of Foreign Arbitral Awards of 1958 as well as a wider recourse to the arbitration rules elaborated by the United Nations Commission on International Trade law. They also advocate that parties should, on the basis of the provisions of the Final Act, be allowed freedom in the choice of arbitrators and the place of arbitration, including the choice of arbitrators and the place of arbitration in a third country.

12. The participating States recognize the important role of scientific and technical progress in the economic and social development of all countries in particular those which are developing from an economic point of view. Taking into account the objectives which countries or institutions concerned pursue in their bilateral and multilateral relations they underline the importance of further developing, on the basis of reciprocal advantage and on the basis of mutual agreement and other arrangements, the forms and methods of co-operation in the field of science and technology provided for in the Final Act, for instance international programmes and co-operative projects, while utilizing also various forms of contacts, including direct and individual contacts among scientists and specialists as well as contacts and communications among interested organizations, scientific and technological institutions and enterprises.

In this context they recognize the value of an improved exchange and dissemination of information concerning scientific and technical developments as a means of facilitating, on the basis of mutual advantage, the study and the transfer of, as well as access to scientific and technical achievements in fields of co-operation agreed between interested parties.

The participating States recommended that in the field of science and technology the ECE should give due attention, through appropriate ways and means, to the elaboration of studies and practical projects for the development of co-operation among member countries. 


\section{THE HELSINKI PROCESS}

Furthermore, the participating States, aware of the relevant part of the Report of the "Scientific Forum", agree to encourage the development of scientific co-operation in the field of agriculture at bilateral, multilaternl and subregional levels, with the aim, inter alia, of improving livestock and plant breeding and ensuring optimum use and conservation of water resources. To this end, they will promote further co-operation among research institutions and centers in their countries, through the exchange of information, the joint implementation of research programmes, the organization of meetings among scientists and specialists and other methods.

The participating States invite the ECE and other competent international organizations to support the implementation of these activities and to examine the possibilities of providing a wider exchange of scientific and technological information in the field of agriculture.

13. The participating States welcome with satisfaction the important steps taken to strengthen co-operation within the framework of the ECE in the field of the environment, including the High-Level Meeting on the Protection of the Environment (13-16 November 1979). Taking due account of work undertaken or envisaged in other competent international organizations, they recommend the continuation of efforts in this field, including, inter alia,

- giving priority to the effective implementation of the provisions of the Resolution on Long-Range Transboundary Air Pollution adopted at the High-Level Meeting;

- the early ratification of the Convention on LongRange Transboundary Air-Pollution signed at the High-Level Meeting;

- implementation of the Recommendations contained in the Declaration of Low and Non-Waste Technology and Reutilization and Recycling of Wastes; 


\section{THE MADRID CONCLUDING DOCUMENT}

- implementation of Decisions B and C of the thirtyfifth session of the ECE concerning the Declaration of Policy on Prevention and Control of Water Pollution, including transboundary pollution;

- support in carrying out the programme of work of the ECE concerning the protection of the environment, including, inter alia, the work under way in the field of the protection of flora and fauna.

14. In the contest of the provisions of the Final Act concerning migrant labor in Europe, the participating States note that recent developments in the world economy have affected the situation of migrant workers. In this connection, the participating States express their wish that host countries and countries of origin, guided by a spirit of mutual interest and co-operation, intensify their contacts with a view of improving further the general situation of migrant workers and their families, inter alia the protection of their human rights including their economic, social and cultural rights while taking particularly into account the special programs of second generation migrants. They will also endeavour to provide or promote, where reasonable demand exists, adequate teaching of the language and culture of the countries of origin.

The participating States recommend that, among other measures for facilitating the social and economic reintegration of returning migrant labour, the payment of pensions as acquired or established under the social security system to which such workers have been admitted in the host country should be ensured by appropriate legislative means or reciprocal agreements.

15. The participating States further recognize the importance for their economic development of promoting the exchange of information and experience on training for management staff. To this end they recommend the organization, in an appropriate existing framework and with the help of interested organizations such as, for example, the ECE 


\section{THE HELSINKI PROCESS}

and the International Labour Organisation, of a symposium of persons responsible for services and institutions specializing in management training for administrations and enterprises with a view to exchanging information cn training problems and methods, comparing experiences and encouraging the development of relations among the centres concerned.

16. The participating States welcome the valuable contribution made by the ECE to the multilateral implementation of the provisions of the Final Act pertaining to cooperation in the fields of economics, of science and technology and of the environment. Aware of the potential of the ECE for intensifying co-operation in the fields, they recommend the fullest use of the existing mechanisms and resources in order to continue and consolidate the implementation of the relevant provisions of the Final Act in the interest of its member countries, including those within the ECE region which are developing from an economic point of view.

17. The participating States, bearing in mind their will expressed in the provisions of the Final Act, reiterate the determination of each of them to promote stable and equitable international economic relations in the mutual interest of all States and, in this spirit, to participate equitably in promoting and strengthening economic co-operation with the developing countries in particular the least developed among them. They also note the usefulness, inter alia, of identifying and executing, in co-operation with developing countries, concrete projects, with a view to contributing to economic development in these countries.

They also declare their readiness to contribute to common efforts towards the establishment of a new international economic order and the implementation of the Strategy for the Third United Nations Development Decade, as adopted. They recognize the importance of the launching of mutually 
THE MADRID CONCLUDING DOCUMENT

beneficial and adequately prepared global negotiations relating to international economic co-operation for development.

\section{QUESTIONS RELATING TO SECURITY AND CO-OPERATION IN THE MEDITERRANEAN}

1. The participating States, bearing in mind that security in Europe, considered in the broader context of world security, is closely linked to security in the Mediterranean areas as a whole, reaffirm their intention to contribute to peace, security and justice in the Mediterranean region.

2. They further express their will

- to take positive steps towards lessening tensions and strengthening stability, security and peace in the Mediterranean and to this end, to inte'isify efforts towards finding just, viable and lasting solutions, through peaceful means. to outstanding crucial problems. without resort to force or other means incompatible with the Principles of the Firial Act, so as to promote confidence and security and make peace prevail in the region;

- to take measures designed to increase confidence and security;

- to develop good neighbourly relations with all States in the region, with due regard to reciprocity, and in the spirit of the principles contained in the Declaration on Principles Guiding Relations between Participating States of the Final Act;

- to study further the possibility of ad hoc meetings of Mediterranean States aimed at strengthening security and intensifying co-operation in the Mediterranean.

3. In addition the participating States will, within the framework of the implementation of the Valletta report, consider the possibilities offered by new transport infrastructure developments to facilitate new commercial and industrial exchanges, as well as by the improvement of existing transport networks, and by a wider co-ordination of transport 


\section{THE HELSINKI PROCESS}

investments between interested parties. In this context they recommend that a study be undertaken, within the framework of the ECE, in order to establish the current and potential transport flows in the Mediterranean involving the participating States and other States of this region taking account of the current work in this field. They will further consider the question of introducing or extending, in accordance with the existing IMO regulations, the use of suitable techniques for aids to maritime navigation, principally in straits.

They further note with satisfaction the results of the Meeting of Experts held in Valletta on the subject of economic, scientific and cultural co-operation within the framework of the Mediterranean Chapter of the Final Act. They reaffirm the conclusions and recommendations of the report of this Meeting and agree that they will be guided accordingly. They also take note of efforts under way aiming at implementing them as appropriate. To this end, the participating States agree to convene from 16 to 26 October 1984 a seminar to be held at Venice at the invitation of the Government of Italy, to review the initiatives already undertaken, or envisaged, in all the sectors outlined in the report of the Valletta Meeting and stimulate, where necessary, broader developments in these sectors.

Representatives of the competent international organizations and representatives of the non-participating Mediterranean States will be invited to this Seminar in accordance with the rules and practices adopted at the Valletta Meeting. ${ }^{3}$

\section{CO-OPERATION IN HUMANITARIAN AND OTHER FIELDS}

The participating States,

Recalling the introductory sections of the Chapter on Co-operation in Humanitarian and other Fields of the Final Act including those concerning the development of mutual 
THE MADRID CONCLUDING DOCUMENT

understanding between them and detente and those concerning progress in cultural and educational exchanges, broader dissemination of information, contacts between people and the solution of humanitarian problems,

Resolving to pursue and expand co-operation in these fields and to achieve a fuller utilization of the possibilities offered by the Final Act,

Agree now to implement the following:

\section{Human Contacts}

1. The participating States will favourably deal with applications relating to contacts and regular meetings on the basis of family ties, reunification of families and marriage between citizens of different States and will decide upon them in the same spirit.

2. They will decide upon these applications in emergency cases for family meetings as expeditiously as possible, for family reunification and for marriage between citizens of different States in normal practice within six months and for other family meetings within gradually decreasing time limits.

3. They confirm that the presentation or renewal of applications in these cases will not modify the rights and obligations of the applications or of members of their families concerning inter alia employment, housing, residence status, family support, access to social, economic or educational benefits, as well as any other rights and obligations flowing from the laws and regulations of the respective participating State.

4. The participating States will provide the necessary information on the procedures to be followed by the applicants in these cases and on the regulations to be observed, as well as, upon the applicant's request, provide the relevant forms. 


\section{THE HELSINKI PROCESS}

5. They will, where necessary, gradually reduce fees charged in connection with these applications, including those for visas and passports, in order to bring them to a moderate level in relation to the average monthly income in the respective participating State.

6. Applicants will be informed as expeditiously as possible of the decision that has been reached. In case of refusal applicants will also be informed of their right to renew applications after reasonably short intervals.

7. The participating States reaffirm their commitment fully to implement the provisions regarding diplomatic and other official missions and consular posts of other participat ing States contained i.s relevant multilateral or bilateral conventions, and to facilitate the normal functioning of those missions. Access by visitors to be these missions will be assured with due regard to the necessary requirements of security of these missions.

8. They also reaffirm their willingness to take. within their competence, reasonable steps, including necessary security measures, when appropriate to ensure satisfactory conditions for activities within the framework of mutual co-operation on their territory, such as sporting and cultural events. in which citizens of other participating States take part.

9. The participating States will endeavour, where appropriate, to improve the conditions relating to legal, consular and medical assistance for citizens of other participating States temporarily on their territory for personal or professional reasons, taking due account of relevant multilateral or bilateral conventions or agreements.

10. They will further implement the relevant provisions of the Final Act, so that religious faiths, institutions, organizations and their representatives can, in the field of their activity, develop contacts and meetings amon $n_{E}$ themselves and exchange information.

11. The participating States will encourage contacts and exchange among young people and foster the broadening 


\section{THE MADRID CONCLUDING DOCUMENT}

of cooperation among their youth organizations. They will favour the holding among young people and youth organizations of educational, cultural and other comparable events and activities. They will also favour the study of problems relating to the younger generation. The participating States will further the development of individual or collective youth tourism, when neressary on the basis of arrangements, inter alia by encouraging the granting of suitable facilities by the transport authorities and tourist organization of the participating States or such facilities as those offered by the railway authorities participating in the "Inter-Rail" system.

\section{Information}

1. The participating States will further encourage the freer and wider dissemination of printed matter, periodical and non-periodical, imported from other participating States, as well as an increase in the number of places where these publications are on public sale. These publications will also be accessible in reading rooms in large public libraries and similar institutions.

2. In particular, to facilitate the improvement of dissemination of printed information, the participating States will encourage contacts and negotiation between their competent firms and organization with a view to concluding long-term agreements and contracts designed to increase the quantities and number of titles of newspapers and other publications imported from other participating States. They consider it desirable that the retail prices of foreign publications are not excessive in relation to prices in their country of origin.

3. They confirm their intention, according to the relevant provisions of the Final Act, to further extend the possibilities for the public to take out subscriptions.

4. They will favour the further expansion of co-operation among mass media and their representatives, especially 


\section{THE HELSINKI PROCESS}

between the editorial staffs of press agencies, newspapers, radio and television organizations as well as film companies. They will encourage a more regular exchange of news, articles, supplements and broadcasts as well as the exchange of editorial staff for better knowledge of respective practices. on the basis of reciprocity, they will improve the material and technical facilities provided for permanently or temporarily accredited television and radio reporters. Moreover, they will facilitate direct contacts among journalists as well as contacts within the framework of professional organizations.

5. They will decide withoui undue delay upon visa applications from journalists and re-examine within a reasonable time frame applications which have been refused. Moreover, journalists wishing to travel for personal reasons and not for the purpose of reporting shall enjoy the same treatment as other visitors from their country of origin.

6. They will grant permanent correspondents and members of their families living with them multiple entry and exit visas valid for one year.

7. The participating States will examine the possibility of granting, where necessary on the basis of bilateral arrangements, accreditation and related facilities to journalists from other participating States who are permanently accredited in third countries.

8. They will facilitate travel by journalists from other participating States within their territories, inter alia by taking concrete measures where necessary, to afford them opportunities to travel more extensively, with the exception of areas closed for security reasons. They will inform journalists in advance, whenever possible, if new areas are closed for security reasons.

9. They will further increase the possibilities and, when necessary, improve the conditions for journalists from other participating States to establish and maintain personal contacts and communication with their sources. 


\section{THE MADRID CONCLUDING DOCUMENT}

10. They will, as a rule, authorize radio and television journalists, at their request, to be accompanied by their own sound and film technicians and to use their own equipment.

Similarly, journalists may carry with them reference material, including personal notes and files, to be used strictly for their professional purposes. 4

11. The participating States will, where necessary, facilitate the establishment and operation, in their capitals, of press centres or institutions performing the same functions, open to the national and foreign press with suitable working facilities for the latter.

They will also consider further ways and means to assist journalists from other participating States and thus to enable them to resolve practical problems they may encounter.

\section{Co-operation and Exchanges in the Field of Culture}

1. They will endeavour, by taking appropriate steps, to make the relevant information concerning possibilities offered by bilateral cultural agreements and programmers available to interested persons, institutions and non-governmental organizations, thus facilitating their effective implementation.

2. The participating States will further encourage wider dissemination of and access to books, films and other forms and means of cultural expression from other participating States, to this end improving by appropriate means, on bilateral and multilateral bases, the conditions for international commercial and non-commercial exchange of their cultural goods, inter alia, by gradually lowering customs duties on these items.

3. The participating States will endeavour to encourage the translation, publication and dissemination of works in the sphere of literature and other fields of cultural activity 


\section{THE HELSINKI PROCESS}

from other participating States, especially those produced in less widely spoken languages, by facilitating co-operation between publishing houses, in particular through the exchange of lists of books which might be translated as well as of other relevan! information.

4. They will contribute to the development of contacts, co-operation and joint projects among the participating States regarding the protection, preservation and recording of historical heritage and monuments and the relationship between man, environment and this heritage, they express their interest in the possibility of convening an inter-governmental conference on these matters within the framework of UNESCO.

5. The participating States will encourage their radio and television organizations to continue developing the presentation of the cultural and artistic achievements of other participating States on the basis of bilateral and multilateral arrangements between these organizations, providing inter alia for exchanges of information on productions, for the broadcasting of shows and programmers from other participating States, for co-productions, for the invitation of guest conductors and directors, as well as for the provision of mutual assistance to cultural film teams.

6. At the invitation of the Government of Hungary a "Cultural Forum" will take place in Budapest, commencing on 15 October 1985 . It will be attended by leading personalities in the field of culture from the participating States. The "Forum" will discuss interrelated problems concerning creation, dissemination and co-operation, including the promotion and expansion of contacts and exchanges in the different fields of culture. A representative of UNESCO will be invited to present to the "Forum" the views of that organization. The "Forum" will be prepared by a meeting of experts, the duration of which will not exceed two weeks and which will be held upon the invita- 
THE MADRID CONCLUDING DOCLMENT

tion of the Government of Hungary in Budapest. commencing 21 November 1984.

\section{Co-operation and Exchanges in the Field of Education}

1. The participating States will promote the establishment of governmental and non-governmental arrangements and agreements in education and science, to be carried out with the participation of educational or other competent institutions

2. The participating States will contribute to the furner improvement of exchanges of students, teachers and scholars and their access to each other's educational. cultural and scientific institutions, and also their access to open information material in accordance with the laws and regulations prevailing in each country. In this context, they will facilitate travel by scholars, teachers and students within the receiving State, the establishment by them of contacts with their colleagues, and will also encourage libraries. higher education establishments and similar institutions in their territorjes to make catalogues and lists of open archival material avallable to scholars, teachers and students from other participating States.

3. They will encourage a more regular exchange of information about scientific training programmes, courses and seminars for young scientists and facilitate a wider participation in these activities of young scientists from different participating States. They will call upon the appropriate national and international organizations and institutions to give support, where appropriate. to the realization of these training activities.

4. The representatives of the participating States noted the usefulness of the work done during the "Scientific Forum" held in Hamburg. Federal Republic of Germany, from 18 February to March 1980. Taking into account the 


\section{THE HELSINKI PROCESS}

results of the "Scientific Forum", the participating States invited international organizations as well as the scientific organizations and scientists of the participating States to give due consideration to its conclusions and recommendations.

5. The participating States will favour widening the possibilities of teaching and studying less widely spread or studied European languages. They will, to this end, stimulate, within their competence, the organization of and attendance at summer university and other courses, the granting of scholarships for translators and the reinforcement of linguistic faculties including, in case of need, the provision of new facilities for studying these languages.

6. The participating States express their readiness to intensify the exchange, among them and within competent international organizations, of teaching materials, school textbooks maps, bibliographies and other educational material, in order to promote better mutual knowledge and facilitate a fuller presentation of their respective countries.

\section{FOLLOW-UP TO THE CONFERENCE}

1. In conformity with the relevant provisions of the Final Act and with their resolve and commitment to continue the multilateral process initiated by the CSCE, the participating States will hold further meetings regularly among their representatives.

The third of these meetings will be held in Vienna commencing on 4 November 1986.

2. The agenda, working programme and modalities of the main Madrid Meeting will be applied mutatis mutandis to the main Vienna Meeting, unless other decisions on these questions are taken by the preparatory meeting mentioned below.

For the purpose of making the adjustments to the agen$\mathrm{da}$, working programme and modalities of the main Madrid 


\section{THE MADRID CONCLUDING DOCUMENT}

Meeting, a preparatory meeting will be held in Vienna commencing on 23 September 1986. It is understood that in this context adjustments concern those items requiring change as a result of the change in data and place, the drawing of lots, and the mention of the other meetings held in conformity with the decisions of the Madrid Meeting 1980. The diration of the preparatory meeting shall not exceed two weeks.

3. The participating States further decide that in 1985 , the tenth Anniversary of the signature of the Final Act of the CSCE will be duly commemorated in Helsinki.

4. The duration of the meetings mentioned in this document; unless otherwise agreed, should not exceed six weeks. The results of these meetings will be taken into account, as appropriate, at the Vienna Follow-up Meeting.

5. All the above-mentioned meetings will be held in conformity with Paragraph 4 of the Chapter on "Followup to the Conference" of the Final Act.

6. The Government of Spain is requested to transmit the present document to the Secretary-General of the United Nations, to the Director-General of UNESCO and to the Executive Secretary of the United Nations Economic Commission for Europe. The Government of Spain is also requested to transmit the present document to the Governments of the non-participating Mediterranean States.

7. The text of this document will be published in each participating State, which will disseminate it and make it known as widely as possible.

8. The representatives of the participating States express their profound gratitude to the people and Government of Spain for the excellent organization of the Madrid Meeting and warm hospitality extended to the delegations which participated in the Meeting. 


\section{ANNEX I \\ Chairman's Statement: Venice Seminar on Economic, Scientific and Cultural Co- operation in the Mediterranean Within the Framework of the Results of the Valletta Meeting of Experts}

1. The Seminar will open on Tuesday, 16 October 1984 at 10 a.m. in Venice, Italy. It will close on Friday, 26 October 1984.

2. The work of the Seminar, guided by a Co-ordinating Committee composed of the delegations of the participating States, will be divided among three Study Groups devoted to Economics, Science and Culture respectively.

3. The first three days of the Seminar will be devoted to six sessions of the Committee.

4. The first session of the Committee will be public and will be devoted to the opening of the Seminar, to be followed by an address by a representative of the host country.

5. The second session of the Committee will decide whether to hold further sessions of the participating States to guide the work of the Study Groups and to take any other decisions necessary for the Seminar.

6. The following four sessions of the Committee will be public and will be devoted to introductory statements by the representatives of the participating States which so desire (in an order selected by lot in advance) and to introductory statements by the representatives of the non-participating Mediterranean States and the international organizations invited. The statements should not exceed 10 minutes per delegation.

7. Beginning on the fourth day and for the following three and a half working days, simultaneous meetings of the three Study Groups will be held. 


\section{THE MADRID CONCLUDING DOCUMENT}

8. The last one and a half days will be devoted to three sessions of the Committee. Two sessions will decide upon the most appropriate use for the documentation presented in the course of the work concerning the specific sectors indicated in the Valletta Report, such as publication of the introductory statements and distribution of the studies to the relevant international organizations, and will make any other necessary decisions.

The final session of the Committee will be public and will be devoted to the official closing of the Seminar with an address by a representative of the host country.

9. The Chair at the opening and closing sessions of both the Committee and the Study Groups will be taken by a representative from the delegation of the host country. Selection of the successive chairmen by lot will then ensure daily rotation of the Chair, in French alphabetical order, among the representatives of the participating States.

10. Participation in the work of the Seminar by the non-participating Mediterranean States (Algeria, Egypt, Israel, Lebanon, Libya, Morocco, Syria and Tunisia) and the international organizations (UNESCO, ECE, UNEP, WHO, ITU) invited will follow the rules and practices adopted at Valletta. This means, inter alia, that they will take part in the work of the three Study Groups and of the four sessions of the Committee on the second and third day as well as its opening and closing sessions.

11. Contributions, on the subjects for consideration in one more of the working languages of the CSCE, may be sent through the proper channels-preferably not later than three months before the opening of the Seminarto the Executive Secretary, who will circulate them to the other participating States, and to the non-participating Mediterranean States and to the international organizations which have notified their intention of taking part.

12. The Italian Government will designate the Executive Secretary of the Seminar. The designation should be 


\section{THE HELSINKI PROCESS}

agreed to by the participating States. The services of a technical secretariat will be provided by the host country.

13. Other rules of procedures, working methods and the scale of distribution for the expenses of the CSCE will, mutatis mutandis, be applied to the Seminar.

14. The arrangements outlined above will not coristitute a precedent for any other CSCE forum.

\section{ANNEX II \\ Chairman's Statement: Bern Meeting of Experts on Human Contacts}

The Chairman notes the absence of objection to the declaration made by the representative of Switzerland on 15 July 1983 extending an invitation by the Swiss Government to hold a meeting of experts on human contacts. Consequently, the Chairman notes that there is agreement to convene such a meeting to discuss the development of contacts among persons, institutions and organizations, with due account for the introductory part of the Chapter of the Final Act entitled Cooperation in Humanitarian and Other Fields and for the introductory part of section one (Human Contacts) of that Chapter, which reads inter alia as follows:

"The participating States,

Considering the development of contacts to be an important element in the strengthening of friendly relations and trust among peoples.

Affirming, in relation to their present effort to improve conditions in this area, the importance they attach to humanitarian considerations,

Desiring in this spirit to develop, with the continuance of détente, further efforts to achieve continuing progress in this field; . . .." 
The meeting will be convened in Bern, on 15 April 1986. Its duration will not exceed six weeks. The meeting will be preceded by preparatory consultations, which will be held in Bern commencing on 2 April 1986. The results of the meeting will be taken into account, as appropriate, at the Vienna Follow-up Meeting.

The Swiss Government will designate the Executive Secretary of the meeting. This designation should be agreed to by the participating States. The services of a technical secretariat will be provided by the host country.

Other rules of procedure, working methods and the scale of distribution for the expenses of the CSCE will be applied, mutatis mutandis, to the Bern meeting.

The Chairman notes further that this statement will be an annex to the concluding document of the Madrid Meeting and will be published with it.

1 Press release 341 of Sept. 12, 1983.

2 In this context, the notion of adjoining sea area is understood to refer also to ocean areas adjoining Europe [text in original].

${ }^{3}$ The organization of the Venice Seminar is set forth in the Chairman's statement of 9 September 1983 (see Annex I) [text in original].

4 In this context it is understood that import of printed matter may be subject to local regulations which will be applied with due regard to the journalists' need for adequate working material [text in original].1

Published by the United States Department of State $\bullet \mathrm{Bu}$ reau of Public Affairs Office of Public Communication Editorial Division - Washington, D.C. - December 1983 Editor: Colleen Sussman $\bullet$ This material is reprinted from the Department of State Bulletin of October 1983. It is in the public domain and may be reproduced without permission; citation of this source is appreciated. 
Appendix D

The Concluding Document of the

Vienna Follow-Up Meeting

\section{CONCLUDING DOCUMENT OF THE VIENNA MEETING 1986 OF REPRESENTATIVES OF THE PARTICIPATING STATES OF THE CONFERENCE ON SECURITY AND CO- OPERATION IN EUROPE, HELD ON THE \\ BASIS OF THE PROVISIONS OF THE FINAL ACT RELATING TO THE FOLLOW-UP TO THE CONFERENCE}

The representatives of the participating States of the Conference on Security and Co-operation in Europe (CSCE), Austria, Belgium, Bulgaria, Canada, Cyprus, Czechoslovakia, Denmark, Finland, France, the German Democratic Republic, the Federal Republic of Germany, Greece, the Holy See, Hungary, Iceland, Ireland, Italy, Liechtenstein, Luxembourg, Malta, Monaco, the Netherlands, Norway, Poland, Portugal, Romania, San Marino, Spain, Sweden, Switzerland, Turkey, the Union of Soviet Socialist Republics, the United Kingdom, the United States of America and Yugoslavia met in Vienna from 4 November 1986 to 19 January 1989 in accordance with the provisions of the Final Act relating to the Follow-Up to the conference, as well as on the basis of the other relevant CSCE documents.

The participants were addressed on 4 November 1986 by the Austrian Federal Chancellor.

Opening statements were made by all Heads of Delegations among whom were Ministers and Deputy Ministers 


\section{THE HELSINKI PROCESS}

of many participating States. Some Ministers of Foreign Affairs addressed the Meeting also at later stages.

The participants were addressed by a representative of the Secretary-General of the United Nations. Contributions were made by representatives of the United Nations Economic Commission for Europe (ECE) and UNESCO.

Contributions were also made by the following nonparticipating Mediterranean States: Algeria, Egypt, Israel, Lebanon, Libya, Morocco, Syria and Tunisia.

The representatives of the participating States reaffirmed their commitment to the CSCE process and underlined its essential role in increasing confidence, in opening up new ways for cooperation, in promoting respect for human rights and fundamental freedoms and thus strengthening international security.

The participating States welcomed the favourable developments in the international situation since the conclusion of the Madrid meeting in 1983 and expressed their satisfaction that the CSCE process has contributed to these developments. Noting the intensification of political dialogue between their countries and the important progress in negotiations on military security and disarmament they agreed that renewed efforts should be undertaken to consolidate these positive trends and to achieve a substantial further improvement of their mutual relations. Accordingly, they reaffirmed their resolve to implement fully, unilaterally, bilaterally and multilaterally, all the provisions of the Final Act and of the other CSCE documents.

As provided for in the Agenda of the Vienna Meeting, the representatives of the participating States held a thorough exchange of views both on the implementation of the provisions of the Final Act, and the Madrid Concluding Document and of the tasks defined by the Conference, as well as, in the context of the questions dealt with by the latter, on the deepening of their mutual relations, the improvements 
of security and the development of cooperation in Europe, and the development of the process of détente in the future.

During this exchange of views the participating States examined thoroughly and in detail the implementation of the Final Act and of the Madrid Concluding Document. Different and at times contradictory opinions were expressed about the extent of the realization of these commitments, while encouraging developments were noted in many areas, the participants criticized the continuing serious deficiencies in the implementation of these documents.

An open and frank discussion was held about the application of and respect for the principles of the Final Act. Concern was expressed about serious violations of a number of these principles. In particular, questions relating to respect for human rights and fundamental freedoms were the focus of intensive and controversial discussion. The participating States agreed that full respect for the principles, in all their aspects, is essential for the improvement of their mutual relations.

The implementation of the provisions of the Final Act concerning confidence-building measures, co-operation in the field of economics, of science and technology and of environment, concerning questions relating to security and cooperation in the Mediterranean as well as co-operation in humanitarian and other fields was discussed. In this context the implementation of the provisions of the Madrid Concluding Document and of other CSCE documents was also discussed. It was considered that the numerous possibilities offered by the Final Act had not been sufficiently utilized.

The participating States also expressed concern about the spread of terrorism and condemned it unreservedly.

The discussion reflected the broader context of the CSCE process and confirmed the importance of taking into account its world dimension in implementing the provisions of the Final Act. 
THE HELSINKI PROCESS

In their deliberations the representatives of the participating States took into account the results of

- the Stockholm Conference on Confidence- and SecurityBuilding Measures and Disarmament in Europe;

- the Athens Meeting of Experts in order to pursue the examination and elaboration of a generally acceptable method for the peaceful settlement of disputes aimed at complementing existing methods;

- the Venice Seminar on Economic, Scientific and Cultural Co-operation in the Mediterranean, the Ottawa Meeting of Experts on Questions concerning Respect, in their States, for Human Rights and Fundamental Freedoms, in all their Aspects, as embodied in the Final Act;

- the Budapest "Cultural Forum";

- the Bern Meeting of Experts on Human Contacts.

The participating States noted moreover that the tenth anniversary of the signing of the Final Act had been commemorated at Helsinki on 1 August 1985.

The participating States reaffirmed their commitment to the continuation of the CSCE process as agreed to in the chapter on the Follow-Up to the Conference contained in the Final Act. Recognizing the need for balanced progress in all sections of the Final Act, they expressed their determination also to benefit from new opportunities for their cooperation and reached corresponding decisions concerning joint follow-up activities.

The representatives of the participating States examined all the proposals submitted to the Meeting and agreed on the following:

\section{QUESTIONS RELATING TO SECURITY IN EUROPE}

The participating States express their determination 
- to build on the current positive developments in their relations in order to make detente a viable, comprehensive and genuine process, universal in scope;

- to assume their responsibility fully to implement the commitments contained in the Final Act and other CSCE documents;

- to intensify their efforts to seek solutions to problems burdening their relations and to strengthen safeguards for international peace and security;

- to promote cooperation and dialogue among them, to ensure the effective exercise of human rights and fundamental freedoms and to facilitate contacts and communication between people;

- to exert new efforts to make further progress to strengthen confidence and security and to promote disarmament.

\section{PRINCIPLES}

1. The participating States reaffirm their commitment to all ten principles of the Final Act's Declaration on Principles Guiding Relations between participating States and their determination to respect them and put them into practice. The participating States reaffirm that all these Principles are of primary significance and, accordingly, will be equally and unreservedly applied, each of them being interpreted taking into account the others.

2. They stress that respect for and full application of these principles as well as strict compliance with all CSCE commitments deriving from them, are of great political importance and essential for building confidence and security as well as for the development of their friendly relations and of their cooperation in all fields.

3. In this context, they confirm that they will respect each other's right freely to choose and develop their political, social, economic and cultural systems as well as their right to determine their laws, regulations, practices and policies. 


\section{THE HELSINKI PROCESS}

In exercising these rights, they will ensure that their laws, regulations, practices and policies conform with their obligations under international law and are brought into harmony with the provisions of the Declaration on Principles and other CSCE commitments.

4. They also confirm that, by virtue of the principle of equal rights and self-determination of peoples and in conformity with the relevant provisions of the Final Act, all peoples always have the right, in full freedom, to determine, when and as they wish, their internal and external political status, without external interference, and to pursue as they wish their political, economic, social and cultural development.

5. They confirm their commitment strictly and effectively to observe the principle of the territorial integrity of States. They will refrain from any violation of this principle and thus from any action aimed by direct or indirect means, in contravention of the purposes and principles of the Charter of the United Nations, other obligations under international law or the provisions of the Final Act, at violating the territorial integrity, political independence or the unity of a State. No actions or situations in contravention of this principle will be recognized as legal by the participating States.

6. The participating States confirm their commitment to the principle of peaceful settlement of disputes, convinced that it is an essential complement to the duty of States to refrain from the threat or use of force, both being essential factors for the maintenance and consolidation of peace and security. They express their determination to pursue continuous efforts to examine and elaborate, on the basis of the relevant provisions of the Final Act and the Madrid Concluding Document, and taking into account the reports of the meetings of experts in Montreux and Athens, a generally acceptable method for the peaceful settlement of disputes aimed at complementing existing methods. In this context they accept, 
THE VIENNA CONCLUDING DOCUMENT

in principle, the mandatory involvement of a third party when a dispute cannot be settled by other peaceful means. 7. In order to ensure the progressive implementation of this commitment, including, as a first step, the mandatory involvement of a third party in the settlement of certain categories of disputes, they decide to convene a Meeting of Experts in Valletta from 15 January to 8 February 1991 to establish a list of such categories and the related procedures and mechanisms. This list would be subject to subsequent gradual extension. The Meeting will also consider the possibility of establishing mechanisms for arriving at binding third-party decisions. The next CSCE Follow-up meeting will assess the progress achieved at the Meeting of Experts. The agenda, timetable and other organizational modalities are set out in Annex I.

8. The participating states unreservedly condemn, as criminal, all acts, methods and practices of terrorism, wherever and by whomever committed, including those which jeopardize friendly relations among States and their security, and agree that terrorism cannot be justified under any circumstances.

9. They express their determination to work for the eradication of terrorism both bilaterally and through multilateral co-operation, particularly in such international fora as the United Nations, the International Civil Aviation Organization and the International Maritime Organization and in accordance with the relevant provisions of the Final Act and the Madrid Concluding Document.

10. Convinced of the need to combire measures at a national level with reinforced international cooperation, the participating States express their intention

$10 \mathrm{a} \bullet$ to pursue a policy of firmness in response to terrorist demands;

$10 \mathrm{~b} \bullet$ to reinforce and develop bilateral and multilateral co-operation among themselves in order to prevent and combat terrorism as well as to increase efficiency in existing 


\section{THE HELSINKI PROCESS}

co-operation at the bilateral level or in the framework of groups of States, including, as appropriate, through the exchange of information;

$10 \mathrm{c}-$ to prevent on their territories illegal activities of persons, groups or organizations that instigate, organize or engage in the perpetration of acts of terrorism or subversive or other activities directed toward the violent overthrow of the regime of another participating State;

10d - to take effective measures for the prevention and suppression of acts of terrorism directed at diplomatic or consular representatives and against terrorism involving violations of the Vienna Conventions on Diplomatic and Consular Relations, in particular their provisions relating to diplomatic and consular privileges and immunities;

10e - to ensure the extradition or prosecution of persons implicated in terrorist acts and to cooperate closely in cases of conflict of jurisdiction where several States are concerned, acting in both respects in accordance with the relevant international agreements;

10f - to consider becoming parties, if they have not yet done so, to the relevant international conventions relating to the suppression of acts of terrorism;

$10 \mathrm{~g}$ to contınue to work in the appropriate international bodies in order to improve and extend measures against terrorism and to ensure that the relevant agreements are accepted and acted upon by as many States as possible. 11. They confirm that they will respect human rights and fundamental freedoms, including the freedom of thought, conscience, religion or belief, for all without distinction as to race. sex, language or religion. They also confirm the universal significance of human rights and fundamental freedoms, respect for which is an essential factor for the peace, justice and security necessary to ensure the development of friendly relations and co-operation among themselves, as among all States. 
12. They express their determination to guarantee the effective exercise of human rights and fundamental freedoms, all of which derive from the inherent dignity of the human person and are essential for his free and full development. They recognize that civil, political, economic, social, cultural and other rights and freedoms are all of paramount importance and must be fully realized by all appropriate means. 13. In this context they will

13a - develop their laws, regulations and policies in the field of civil, political, economic, social cultural and other human rights and fundamental freedoms and put them into practice in order to guarantee the effective exercise of these rights and freedoms;

$13 \mathrm{~b}-$ consider acceding to the International Covenant on Civil and Political Rights, the International Covenant on Economic, Social and Cultural Rights, the Optional Protocol to the Covenant on Civil and Political Rights and other relevant international instruments, if they have not yet done so;

$13 \mathrm{c}-$ publish and disseminate the text of the Final Act, of the Madrid Concluding Document, and of the present Document as well as those of any relevant international instruments in the field of human rights, in order to ensure the availability of these documents in their entirety, to make them known as widely as possible and to render them accessible to all individuals in their countries, in particular through public library systems;

$13 \mathrm{~d} \bullet$ ensure effectively the right of the individual to know and act upon his rights and duties in this field, and to that end publish and make accessible all laws, regulations and procedures relating to human rights and fundamental freedoms;

13e - respect the right of their citizens to contribute actively, individually or in association with others, to the promotion and protection of human rights and fundamental freedoms; 


\section{THE HELSINKI PROCESS}

$13 \mathrm{f}-$ encourage in schools and other educational institutions consideration of the promotion and protection of human rights and fundamental freedoms;

$13 \mathrm{~g} \bullet$ ensure human rights and fundamental freedoms to everyone within their territory and subject to their jurisdiction, without distinction of any kind such as race, color, sex, language, religion, political or other opinion, national or social origin, property, birth or other status;

$13 \mathrm{~h}-$ ensure that no individual exercising, expressing the intention to exercise or seeking to exercise these rights and freedoms, or any member of his family, will as a consequence be discriminated against in any manner;

$13 \mathrm{i} \bullet$ ensure that effective remedies as well as full information about them are available to those who claim that their human rights and fundamental freedoms have been violated; they will, inter alia, effectively apply the following remedies:

- the right of the individual to appeal to executive, legislative, judicial or administrative organs;

- the right to a fair and public hearing within a reasonable time before an independent and impartial tribunal, including the right to present legal arguments and to be represented by legal counsel of one's choice;

- the right to be promptly and officially informed of the decision taken on any appeal, including the legal grounds on which this decision was based. This information will be provided as a rule in writing and, in any event, in a way that will enable the individual to make effective use of further available remedies.

14. The participating States recognize that the promotion of economic, social, cultural rights as well as of civil and political rights is of paramount importance for human dignity and for the attainment of the legitimate aspirations of every individual. They will therefore continue their efforts with a view to achieving progressively the full realization of economic, social and cultural rights by all appropriate 
means, including in particular by the adoption of legislative measures.

In this context they will pay special attention to problems in the areas of employment, housing, social security, health, education and culture. They will promote constant progress in the realization of all rights and freedoms within their countries, as well as in the development of their relations among themselves and with other States, so that everyone will actually enjoy to the full his economic, social and cultural rights as well as his civil and political rights. 15. The participating States confirm their determination to ensure equal rights of men and women. Accordingly, they will take all measures necessary, including legislative measures, to promote equally effective participation of men and women in political, economic, social and cultural life. They will consider the possibility of acceding, if they have not yet done so, to the Convention on the Elimination of All Forms of Discrimination Against Women.

16. In order to ensure the fretdom of the individual to profess and practice religion or belief the participating States will, inter alia,

16a take effective measures to prevent and eliminate discrimination against individuals or communities, on the grounds of religion or belief in the recognition, exercise and enjoyment of human rights and fundamental freedoms in all fields of civil, political, economic, social and cultural life, and ensure the effective equality between believers and non-believers;

$16 \mathrm{~b}$ - foster a climate of mutual tolerance and respect between believers of different communities as well as between believers and non-believers;

$16 \mathrm{c} \bullet$ grant upon their request to communities of believers, practising or prepared to practise their faith within the constitutional framework of their states, recognition of the status provided for them in their respective countries;

$16 \mathrm{~d} \bullet$ respect the right of religious communities to 


\section{THE HELSINKI PROCESS}

- establish and maintain freely accessible places of worship or assembly,

- organize themselves according to their own hierarchical and institutional structure,

- select, appoint and replace their personnel in accordance with their respective requirements and standards as well as with any freely accepted arrangement between them and their State,

- solicit and receive voluntary financial and other contributions;

16e - engage in consultations with religious faiths, institutions and organizations in order to achieve a better understanding of the requirements of religious freedom;

$16 f-$ respect the right of everyone to give and receive religious education in the language of his choice, individually or in association with others;

$16 \mathrm{~g}-$ in this context respect, inter alia, the liberty of parents to ensure the religious and moral education of their children in conformity with their own convictions;

$16 \mathrm{~h}-$ allow the training of religious personnel in appropriate institutions;

$16 \mathrm{i}$ - respect the right of individual believers and communities of believers to acquire, possess, and use sacred books, religious publications in the language of their choice and other articles and materials related to the practice of religion or belief;

$16 \mathrm{j}-$ allow religious faiths, institutions and organizations to produce and import and disseminate religious publications and materials;

$16 \mathrm{k}-$ favorably consider the interest of religious communities in participating in public dialogue, inter alia, through mass media;

17. The participating States recognize that the exercise of the above-mentioned rights relating to the freedom of religion or belief may be subject only to such limitations as are provided by law and consistent with their obligations 
under international law and with their international commitments. They will ensure in their laws and regulations and in their application the full and effective implementation of the freedom of thought, conscience, religion or belief; 18. The participating States will exert sustained efforts to implement the provisions of the Final Act and of the Madrid Concluding Document pertaining to national minorities. They will take all the necessary legislative, administrative, judicial and other measures and apply the relevant international instruments by which they may be found, to ensure the protection of human rights and fundamental freedoms of persons belonging to national minorities within their territory. They will refrain from any discrimination against such persons and contribute to the realization of their legitimate interests and aspirations in the field of human rights and fundamental freedoms.

19. They will protect and create conditions for the promotion of the ethnic, cultural, linguistic and religious identify of national minorities on their territory. They will respect the free exercise of rights by persons belonging to such minorities and ensure their full equality with others.

20. The participating States will respect fully, the right of everyone

- to freedom of movement and residence within the borders of each State, and

- to leave any country, including his own, and to return to his country.

21. The participating States will ensure that the exercise of the above-mentioned rights shall not be subject to any restrictions except to those which are provided by law and consistent with their obligations under international law, in particular the International Covenant on Civil and Political Rights and their international commitments, in particular the character of exceptions. The participating States will ensure that these restrictions are not abused and are not 


\section{THE HELSINKI PROCESS}

applied in an arbitrary manner, but in such a way that the effective exercise of these rights is ensured.

22. In this context they will allow all refugees who so desire to return in safety to their homes.

23. The participating states will

23a - ensure that no one shall be subjected to arbitrary arrest, detention or exile;

23b - ensure that all individuals in detention or incarceration will be treated with humanity and with respect for their inherent dignity of the human person;

23c - observe the UN Standard Minimum Rules for the Treatment of Prisoners as well as the UN Code of Conduct for Law Enforcement Officials;

$23 \mathrm{~d} \bullet$ prohibit torture and other cruel, inhuman or degrading treatment or punishment and take effective legislative, administrative, judicial and other measures to prevent and punish such practices;

23e - consider acceding to the Convention against Torture and other Cruel, Inhuman or Degrading Treatment or Punishment, if they have not yet done so;

$23 f \bullet$ protect individuals from any psychiatric or other medical practices that violate human rights and fundamental freedoms and take effective measures to prevent and punish such practices.

24. With regard to the question of capital punishment, The participating States note that capital punishment has been abolished in a number of them. In participating States where capital punishment has not been abolished, sentence of death may be imposed only for the most serious crimes in accordance with the law in force at the time of the commission of the crime and not contrary to their international commitments. This question will be kept under consideration. In this context, the participating States will cooperate within relevant international organizations.

25. The participating States will, with the aim of developing mutual understanding and confidence, promoting friendly 
and good neighborly relations, strengthening international peace, security and justice and of improving the implementation of their CSCE commitments, further develop cooperation and promote dialogue between them in all fields and at all levels on the basis of full equality. They agree that full respect for and application of the Principles and the fulfillment of the other CSCE provisions will improve their relations and advance the development of their cooperation. They will refrain from any action inconsistent with the provisions of the Final Act and other CSCE documents and recognize that any such action would impair relations between them and hinder the development of cooperation among them.

26. They confirm that governments, institutions, organizations and persons have a relevant and positive role to play in contributing tot he achievement of the aims of their cooperation and to the full realization of the Final Act. To that end they will respect the right of persons to observe and promote the implementation of CSCE provisions and to associate with others for this purpose. They will facilitate direct contacts and communication among these persons, organizations and institutions within and between participating States and remove, where they exist, legal and administrative impediments inconsistent with the CSCE provisions. They will also take effective measures to facilitate access to information on the implementation of CSCE provisions and the free expression of views on these matters.

27. The participating States heard accounts of the Meeting of Experts on questions concerning respect, in their states, for Human Rights and Fundamental Freedoms, in all their aspects, as embodied in the Final Act, held in Ottawa from 7 May to 17 June 1985. They welcomed the fact that frank discussions had taken place on matters of key concern. Noting that these discussions had not led to agreed conclusions, they agreed that such thorough exchanges of views themselves constitute a valuable contribution to the CSCE proc- 
THE HELSINKI PROCESS

ess. In this respect it was noted in particular that proposals made at the meeting had received further consideration at the Vienna Follow-Up Meeting. They also welcomed the decision to allow public access to part of the meeting and noted that this principle was further developed at later meetings.

\section{CONFIDENCE- AND SECURITY-BUILDING MEASURES AND CERTAIN ASPECTS OF SECURITY AND DISARMAMENT IN EUROPE}

\section{STOCKHOLM CONFERENCE: ASSESSMENT OF PROGRESS ACHIEVED}

The participating States,

In accordance with the relevant provisions of the Madrid Concluding Document, assessed progress achieved during the Conference on Confidence- and Security-building Measures and Disarmament in Europe, which met in Stockholm from 17 January 1984 to 19 September 1986.

They welcomed the adoption at Stockholm of a set of mutually complementary confidence- and security-building measures (CSBMS).

They noted that these measures are in accordance with the criteria of the Madrid mandate and constitute a substantial improvement and extension of the confidence-building measures adopted in the Final Act.

They noted that the adoption of the Stockholm Document was a politically significant achievement and that its measures are an important step in efforts aimed at reducing the risk of military confrontation in Europe. They agreed that the extent to which the measures will in practice contribute to greater confidence and security will depend on the record of implementation. They were encouraged by initial implementation and noted that further experience and 
detailed review will be required. They reaffirmed their determination to comply strictly with and apply in good faith all the provisions of the Document of the Stockholm Conference.

They reaffirmed their commitment to the provisions of the Madrid Concluding Document relating to the Conference on Confidence- and Security-building Measures and Disarmament in Europe and agreed to resume the work of the Conference with a view to achieving further progress towards its aim.

\section{NEW EFFORTS FOR SECURITY AND DISARMAMENT IN EUROPE}

The participating States,

Recalling the relevant provisions of the Final Act and of the Madrid Concluding Document according to which they recognize the interest of all of them in efforts, aimed at lessening military confrontation and promoting disarmament,

Reaffirming their determination expressed in the Final Act to strengthen confidence among them and thus to contribute to increasing stability and security in Europe,

Stressing the complementary nature of the efforts within the framework of the CSCE process aimed at building confidence and security and establishing stability and achieving progress in disarmament, in order to lessen military confrontation and to enhance security for all,

Stressing that in undertaking such efforts they will respect the security interests of all CSCE participating States inherent in their sovereign equality,

Having also considered ways and appropriate means to continue their efforts for security and disarmament in Europe,

Have reached the understanding that these efforts should be structured as set forth below: 
THE HELSINKI PROCESS

\section{NEGOTIATIONS ON CONFIDENCE- AND SECURITY-BUILDING MEASURES}

The participating States have agreed that Negotiations on Confidence- and Security-building Measures will take place in order to build upon and expand the results already achieved at the Stockholm Conference with the aim of elaborating and adopting a new set of mutually complementary confidence- and security-building measures designed to reduce the risk of military confrontation in Europe. These negotiations will take place in accordance with the Madrid mandate. The decisions of the Preparatory Meeting held in Helsinki from 25 October to 11 November 1983 will be applied mutatis mutandis (see Annex II).

These negotiations will take place in Vienna, commencing in the week beginning on 6 March 1989.

The next Follow-up Meeting of the participating States of the CSCE, to be held in Helsinki, commencing on 24 March 1992, will assess the progress achieved in these negotiations.

\section{NEGOTIATION ON CONVENTIONAL ARMED FORCES IN EUROPE}

The Negotiation on Conventional Armed Forces in Europe will take place as agreed by those States named in the mandate contained in the Chairman's statement in Annex III of this document, who among themselves have determined the agenda, the rules of procedure and the organizational modalities of these negotiations, and will determine their timetable and results. These negotiations will be conducted within the framework of the CSCE process.

These negotiations will take place in Vienna, commencing in the week beginning on 6 March 1989.

The next Follow-Up Meeting of the participating States of the CSCE, to be held in Helsinki, commencing on 24 
March 1992, will exchange views on the progress achieved in these negotiations.

MEETINGS IN ORDER TO EXCHANGE VIEWS AND INFORMATION CONCERNING THE COURSE OF THE NEGOTIATION ON CONVENTIONAL ARMED FORCES IN EUROPE

It has been agreed that the participating States will hold meetings in order to exchange views and information concerning the course of the Negotiation on Conventional Armed Forces in Europe.

These meetings will be held at least twice during each session of the Negotiation on Conventional Armed Forces in Europe.

Provisions on practical modalities relating to these meetings are contained in Annex IV of this document.

At these meetings, substantive information will be provided by the participants in the Negotiation on Conventional Armed Forces in Europe on developments, progress and results in the negotiations with the aim of enabling each participating State to appraise their course.

The participants in these negotiations have undertaken to take into consideration, in the course of their negotiations, the views expressed at such meetings by other participating States concerning their own security.

Information will also be provided on a bilateral basis.

The next Follow-up Meeting of the participating States of the CSCE, to be held in Helsinki, commencing on 24 March 1992, will consider the functioning of these arrangements.

Taking into account the relevant provisions of the Final Act and of the Madrid Concluding Document, and having considered the results achieved in the two negotiations, and also in the light of other relevant negotiations on security 


\section{THE HELSINKI PROCESS}

and disarmament affecting Europe, a future CSCE followup meeting will consider ways and appropriate means for the participating States to continue their efforts for security and disarmament in Europe, including the question of supplementing the Madrid mandate for the next stage of the Conference on Confidence- and Security-building Measures and Disarmament in Europe.

\section{CO-OPERATION IN THE FIELD OF ECONOMICS, OF SCIENCE AND TECHNOLOGY AND OF THE ENVIRONMENT}

The participating States reaffirm their willingness to further their co-operation in the field of economics, of science and technology and of the environment, and to promote stable and equitable international economic relations in the interest of all States. They express their readiness to intensify the dialogue in the competent fora with a view to facilitating appropriate solutions for key interrelated economic issues such as money, finance, debt and trade. In this connection, they stress the importance of policies aimed at promoting structural adjustments, stimulating the growth of national economies and creating an international economic environment conducive to developme:t.

The participating States recognize the important role of the United Nations Economic Commission for Europe (ECE) in fostering regional economic co-operation and in contributing to the implementation of the provisions of the Final Act and subsequent CSCE documents. They express their readiness to make further use of the existing framework, resources and experience of the ECE in areas which are of significance for the implementation of recommendations of the CSCE. 


\section{TRADE AND INDUSTRIAL COOPERATION}

1. In order to make better use of their economic potential, and to foster the expansion of their commercial exchanges, the participating States will make further efforts to promote favourable conditions for trade and industrial co-operation, taking into account all the relevant provisions of the Final Act and the Madrid Concluding Document.

2. The participating States recognize the importance of favourable business conditions for the development of trade between them. They will facilitate direct contacts between businesspeople, potential buyers and end-users, including onsite contacts relevant to the business intended or being transacted. They will take measures to improve working conditions for businesspeople regarding, inter alia, accreditation, accommodation, communications, recruitment and management of personnel, and to avoid unjustifiable delays in visa procedures and customs clearance. Further, they recognize the opportunities offered by trade fairs and exhibitions for developing commercial contacts and achieving concrete business results.

3. The participating States will continue their efforts further to reduce or progressively eliminate obstacles of all kinds to trade, thus contributing to the expansion and diversification of their commercial relations. They express their support for the work done in this field in appropriate international fora.

4. The participating States will encourage forms of trade compatible with the efficient conduct of international business relations and will also encourage business partners to decide independently upon their trading patterns. As to compensation transactions in all their forms, they recommend that such proposals be addressed at the beginning of negotiations and, when agreed upon, dealt with in a flexible way, especially regarding the choice of products. In this connection, the special concerns of small- and medium-sized enter- 


\section{THE HELSINKI PROCESS}

prises should be taken into account. The participating States recognize the valuable role of the ECE in dealing with questions related to compensation transactions.

5. The participating States recognize that, within their respective economies, increased autonomy for enterprises can help achieve a better response to market needs and thus contribute to the development of trade and co-operation among them.

6. In order to facilitate the identification of market opportunities, the participating States will further promote the publication and availability of comprehensive, comparable and timely economic and commercial information. They will publish up to date macroeconomic information and statistics, and envisage making balance of payments figures available. They will also provide the United Nations trade databank. COMTRADE, with detailed data in a format relevant to the efficient conduct of foreign trade. They will encourage co-operation between their statistical services and within the framework of the ECE in order, inter alia, to facilitate the identification of disparities in foreign trade statistics and to improve the international comparability of such statistics. Furthermore, they consider it useful to increase the publication and exchange of statistics on such topics as demography, public health, agriculture, the environment and energy.

7. Noting the growing importance of services in their mutual economic relations, the participating States will examine, in appropriate bodies, developments in this area and prospects for improved access to the service's market.

8. Affirming the importance of industrial co-operation in their long-term economic relations, the participating States will promote measures designed to create favourable conditions for the development of such co-operation. They will therefore examine, within the competent fora, the improvement of the legal, administrative and economic framework for industrial co-operation. Furthermore, they will encourage 
contacts between potential partners, develop exchanges of appropriate information and promote the participation of small- and medium-sized enterprises in industrial co-operation.

9. The participating States recognize that productive, competitive and profit-earning joint ventures can play a role in mutually beneficial industrial co-operation. They will improve the legal, administrative and financial conditions for investment in, and operation of, joint ventures. They will also promote the exchange of all information relevant to the establishment of joint ventures, including all necessary technical information, as well as information on management, labour conditions, accounting and taxation, repatriation of profits and the protection of investrnents, production conditions and access to domestic supplies and markets.

10. The participating States stress the importance of their standardization policies and practices, and of related activities for the facilitation of international trade, especially regarding products subject to compulsory certification. Accordingly, they will consider mutual recognition of their national testing and certification procedures and practices, and promote co-operation among relevant national bodies and within international organizations including the ECE.

11. The participating States recognize the growing importance of effective marketing in the development of trade and industrial co-operation, in the production and promotion of new products and in meeting the needs of the consumer. Given the growth of marketing opportunities, they will seek to improve the conditions for firms and organizations engaging in research into domestic or foreign markets and in other marketing activities.

12. The participating States affirm the usefulness for all enterprises, and especially for small- and medium-sized ones, of flexible and mutually agreed arbitration provisions for ensuring the equitable settlement of disputes in international trade and industrial co-operation. Bearing in mind the rel- 


\section{THE HELSINKI PROCESS}

evant provisions of the Final Act and Madrid Concluding Document they attach particular importance to freedom in the choice of arbitrators, including the presiding arbitrator, and of the country of arbitration. They recommend that consideration be given to the adoption of the Model Law on international commercial arbitration of the United Nations Commission on International Trade Law (UNCITRAL). In addition, they recognize the value of agreements on cooperation in the field of commercial arbitration between Chambers of Commerce and other arbitration bodies.

13. The participating States agree to convene a Conference on Economic Co-operation in Europe. This Conference will take place in Bonn from 19 March to 11 April 1990. The aim of the conference is to provide new impulses for economic relations between participating States, in particular by improving business conditions for commercial exchanges and industrial co-operation, and by considering new possibilities for, and ways of, economic co-operation. The Conference will be attended by representatives of the participating States and of the business community. The agenda, timetable and other organizational modalities are set out in Annex V. The new Follow-up meeting, to be held in Helsinki, commencing on 14 March 1992, will assess the results achieved at the conference

\section{SCIENCE AND TECHNOLOGY}

14. The participating States emphasize the important role of science and technology in their overall economic and social development, bearing in mind particularly those sciences and technologies which are of direct relevance to improving the quality of life.

15. Recognizing the importance of scientific and technological co-operation, the participating States will develop further mutually advantageous co-operation in the fields already set forth in the Final Act, and will examine possibili- 


\section{THE VIENNA CONCLUDING DOCUMENT}

ties for co-operation in new areas of growing importance and common interest. Furthermore, they express their intention to improve conditions for such co-operation by fostering the exchange of information on, and experience with, scientific and technological achievements. having in mind especially the interests of the countries of the region which are developing from the economic point of view.

16. The participating States also reaffirm the role of general inter-governmental agreements as well as of bilateral agreements involving universities, scientific and technological institutions and industry, in developing mutually beneficial exchanges. Underlining the importance of freedom of communication and exchange of views for progress in science and technology, they will promote and support direct and individual contacts between scientists, specialists and interested business people. Recalling the conclusions reached at the Hamburg Scientific Forum, they will respect human rights and fundamental freedoms, which represent one of the foundations for a significant improvement in international scientific co-operation at all levels, they will also endeavor to create conditions enabling interested partners to develop appropriate joint research programmes and projects on the basis of reciprocity and mutual advantage and, when appropriate, on a commercial basis.

17. Given the depletion of natural resources, including nonrenewable sources of energy, the participating States will promote co-operation in the rational use of such resources, and in the use of alternative sources of energy, including thermonuclear fusion.

18. Taking note of the progress made in, and the new opportunities offered by, research and development in biotechnology, the participating States consider it desirable to enhance the exchange of information on laws and regulations relating to the safety aspects of genetic engineering. They will therefore facilitate consultation and exchange of information on safety guidelines. In this context, they emphasize 


\section{THE HELSINKI PROCESS}

the importance of ethical principles when dealing with genetic engineering and its application.

19. The participating States will develop their co-operation in medical and related sciences by intensifying research and the exchange of information on drug abuse and on new or increasingly wide-spread diseases. They will co-operate in particular in combating the spread of AIDS, taking into account the global AIDS Strategy of the World Health Organization (WHO). They will also co-operate in research concerning the long-term consequences of radiation.

20. The participating States recognize the importance of scientific research, of environmentally sound technologies and, in particular, of improved international cooperation in these fields, for the monitoring, prevention and reduction of pollution. They will therefore promote, inter alia, within the relevant international fora, exchange of information on, and experience with, these technologies. In this respect they will also promote, on a commercial basis, exchanges in the fields of pollution-abatement technologies, technologies and products with less or no emission of ozone-depleting substances, processing and combustion techniques, new methods of waste treatment, including recycling and disposal, and low- and non-waste technologies.

21. The participating States will exchange appropriate information in specific fields of engineering industries and automation. They will do this on the basis of mutual advantage for potential partners, who will decide independently on the areas of co-operation and with due respect for bilateral and multilateral agreements. To this end they will, inter alia, develop statistics in fields of engineering industries of commercial importance.

22. In the context of their scientific and technological cooperation, the participating States will consider the possibility of encouraging the development and use of alternatives to animal experimentation, including for product testing, on animals. 
23. In the important field of nuclear energy, the participating States recognize that, while individual States should assume full responsibility for the safety of their own nuclear facilities, nuclear safety requires closer international co-operation, especially within the International Atomic Energy Agency (IAEA). They note that it is essential to maintain the highest possible safety standards in the management and operation of nuclear facilities. They therefore support the work done within the IAEA in developing basic safety principles, and urge all States to use the revised Nuclear Safety StandardsNUSS codes-as a basis for regulating safety practices. They also recall the need further to improve the efficiency of the existing system of nuclear liability.

\section{ENVIRONMENT}

24. Recognizing the need for preventive action, the participating States will strengthen their co-operation and intensify efforts aimed at protecting and improving the environment, bearing in mind the need to maintain and restore the ecological balance in air, water and soil. They will do this by, inter alia, developing their internal legislation and international commitments, and by applying the best available means, taking into account levels of development as well as economic and technical constraints. They underline the importance of the Regional Strategy for Environmental Protection and Rational Use of Natural Resources in ECE Member Countries Covering the Period up to the Year 2000 and beyond. They welcome, and will take due account of, the report of the World Commission on Environment and Development and the Environmental Perspective to the year 2000 and beyond, as well as the work already undertaken within the competent international fora, in particular within the framework of the 1979 Convention on Long-Range Transboundary Air Pollution (hereafter called "the Convention"). 


\section{THE HELSINKI PROCESS}

25. The participating States are convinced of the need for timely and effective reductions of sulphur emissions on their transboundary fluxes. They call upon contracting parties and signatories to the Convention to become parties to the Protocol on the reduction of sulphur emissions or their transboundary fluxes by at least 30 percent. They recommend that further steps to reduce sulphur emissions, in line with the objectives of the Protocol, be taken by those States which are not parties to the Protocol, and that those States where this goal is already accomplished continue to control their emissions. Recalling that the said protocol provides for reductions of sulphur emissions at the latest by 1993, they will work within the framework of the convention for the elaboration at an early date of an arrangement for further reductions of sulphur emissions beyond the level established by the protocol.

26. The participating States consider that control and reduction of nitrogen oxide emissions, or their transboundary fluxes, deserve high priority in their pollution abatement programmes. They welcome the elaboration and adoption of a protocol on control of nitrogen oxide emissions.

27. They recognize the need to develop, within the framework of the Convention, arrangements to reduce emissions of other relevant air pollutants such as hydrocarbons and those producing photochemical oxidants. They will strengthen their co-operation accordingly, including by collecting and processing the necessary information.

28. The participating States agree to strengthen and develop the Cooperative Programme for the Monitoring and Evaluation of the Long-Range Transmission of Air Pollutants in Europe (EMEP), inter alia through extending and improving the system of monitoring stations, providing EMEP with the necessary information regarding emissions of pollutants, furthering developing comparable methods of measurement, and expanding coverage to include other relevant air pollutants, in particular nitrogen oxides, hydrocarbons and photo- 
chemical oxidants. They also recommend that those countries which have not yet done so should become parties to the Protocol on the Long-Term Financing of EMEP. 29. The participating States will make every effort to become parties, as soon as possible, to the Vienna Convention for the Protection of the Ozone Layer and to the Montreal Protocol on Substances that Deplete the Ozone Layer. Further, they will foster national action and international cooperation on the control and reduction of the emission of ozone-depleting substances.

30. The participating States agree that further national and international research efforts should be made regarding the global warming phenomenon, and the role played therein by emissions of carbon dioxide and tract gases in order to provide a scientific basis for mitigative action.

31. In order to protect and improve freshwater resources and to reduce significantly the pollution of seas and coastal areas, transboundary watercourses and international lakes from all sources of pollution, the participating States will develop and intensity national efforts as well as bilateral and multilateral co-operation. They recommend the elaboration of a framework convention or specific conventions to improve the protection of transboundary watercourses and international lakes. They will reduce significantly discharges of toxic, persistent and potentially hazardous substances. Furthermore, they will devote special attention to the development of appropriate alternatives to sea disposal in order to decrease progressively and substantially the dumping of harmful wastes and the incineration of noxious liquid wastes at sea, with a view to the early termination of such methods. 32. The participating States recognize the need to improve international co-operation on the transboundary movement of hazardous wastes. Taking into account the valuable work done in other international fora, they will encourage the elaboration of international agreements, including a global 


\section{THE HELSINKI PROCESS}

convention on the control of transboundary movements of hazardous wastes.

33. The participating States will seek closer co-operation and greater exchange of information on the problems associated with potentially hazardous chemicals, including assessment of the risks to health and the environment. They will explore possibilities for closer harmonization of their legislation and regulations on the handling of these chemicals. 34. The participating States will strengthen international cooperation on natural resources and flora and fauna. They will promote early accession to, and effective implementation of, relevant agreements. They will also develop further effective measures to combat soil degradation and to protect flora, fauna and their habitats on the basis of the Declaration on this subject adopted by the ECE. They will intensify their exchanges of views and experience on ways and measures of achieving a more rational use of natural resources. 35. The participating States acknowledge the importance of the contribution of persons and organizations dedicated to the protection and improvement of the environment, and will allow them to express their concerns. They will promote greater public awareness and understanding of environmental issues and will co-operate in the field of environmental education, inter alia through exchanges of experience and results of research studies, development of educational programmes and ecological training.

36. The participating States will co-operate bilaterally and multilaterally with a view to improving and co-ordinating their arrangements for prevention, early warning, exchange of information and mutual assistance in cases of industrial accidents likely to cause transboundary damage to the environment. They will also initiate the examination of key elements related to the transboundary character of industrial accidents, such as clean up, restoration and liability.

37. The participating States agree to convene a Meeting on the protection of the environment. This Meeting will 
take place in Sofia from 16 October to 3 November 1989. The aim of the meeting is to elaborate recommendations on principles and guidelines for further measures and cooperation in new and important areas of environmental protection. The agenda, timetable and other organizational modalities are set out in Annex VII. The next Follow-up meeting, to be held in Helsinki, commencing on 24 March 1992 will assess the results achieved at the meeting.

\section{CO-OPERATION IN OTHER AREAS}

38. The participating States recognize the important role of transport in economic and social development and the overall consequences of increased activity in the transport sector, including problems related to the environment. They will therefore encourage the elaboration of measures for achieving an economically more efficient transport system, taking into account the relative merits of different modes of transport and their potential effects on human health, safety and the environment. In this connection they will, through bilateral and multilateral means, give particular attention to questions concerning multimodal transport networks combined transport, transit flows and the simplification of transport formalities and, in particular, of transport documents. They also welcome the work done by the ECE in this context.

39. The participating States underline the economic importance of tourism and its contribution to the mutual understanding of peoples. They therefore favour the development of co-ooperation in this field and will facilitate normal contacts between tourists and the local population. To this end they will endeavour to improve the infrastructure for tourism, inter alia, by diversifying accommodation and by developing facilities for low-budget and youth tourism, including small-scale private accommodation. They will also consider 


\section{THE HELSINKI PROCESS}

in a positive spirit the progressive phasing out for foreign tourists of minimum exchange requirements where they apply, allow the reconversion of legally acquired local currency, and furthermore, encourage non-discriminatory pricing for all foreign tourists irrespective of their nationality. They will also reduce arrival and departure procedures to the necessary minimum. The participating States will create conditions conducive to the establishment of joint projects in the field of tourism, including joint ventures and personnel training programmes.

40. The participating States emphasize the need for effective implementation of the provisions of the Final Act and the Madrid Concluding Document relating to migrant workers and their families in Europe. They invite host countries and countries of origin to make efforts to improve further the economic, social, cultural and other conditions of life for migrant workers and their families legally residing in the host countries. They recommend that host countries and countries of origin should promote their bilateral co-operation in relevant fields with a view to facilitating the reintegration of migrant workers and their families returning to their country of origin.

41. The participating States will, in accordance with their relevant commitments undertaken in the Helsinki Final Act and the Madrid Concluding Document, consider favourably applications for family reunification as well as family contacts and visits involving migrant workers from other participating States legally residing in the host countries.

42. The participating States will ensure that migrant workers from other participating States and their families can freely enjoy and maintain their national culture and have access to the culture of the host country.

43. Aiming at ensuring effective equality of opportunity between the children of migrant workers and the children of their own nationals regarding access to all forms and levels of education, the participating States affirm their read- 
iness to take measures needed for the better use and improvement of educational opportunities. Furthermore, they will encourage or facilitate, where reasonable demand exists, supplementary teaching in their mother tongue for the children of migrant workers.

44. The participating States recognize that issues of migrant workers have their human dimension.

45. The participating States acknowledge that the impact of economic and technological change is being acutely felt in the work place. They underline their readiness to encourage co-operation in the field of vocational training policy through increased exchange of information and experience. with the aim of enhancing the educational standards, professional knowledge, skills and adaptability of personnel involved in industry and commerce.

46. The participating States recognize the importance of facilitating the integration of young people into professional life. They will therefore continue their efforts to ensure the necessary conditions for the education and vocational training of young people and to promote youth employment opportunities in various sectors of the economy. They will continue their efforts to create conditions for developing the level of scientific and cultural knowledge of their citizens, especially of young people, and for facilitating their access to achievements in the areas of natural and social sciences, as well as culture.

\section{QUESTIONS RELATING TO SECURITY AND COOPERATION IN THE MEDITERRANEAN}

The participating States,

reaffirm their commitment to, and stress the continuing relevance of, the provisions of their Final Act and the Madrid Concluding Document concerning security and cooperation in the Mediterranean; in this context, they underline 
THE HELSINKI PROCESS

the relevance of the Mediterranean paragraph in the Stockholm Document.

They stress the importance of the CSCE process for increasing security and improving cooperation in the Mediterranean area.

They reiterate their conviction that security in Europe is to be considered in the broader context of world security and is closely linked with security in the Mediterranean area as a whole, and that accordingly the process of improving security should not be confined to Europe but should extend to other parts of the world, and in particular to the Mediterranean area.

They express their concern over the continuing tensions in the region and renew their willingness to intensify efforts towards finding just, viable and lasting solutions, through peaceful means, to outstanding crucial problems.

They consider that broader and more active cooperation could contribute to increase mutual understanding and enhanced confidence, thereby promoting stability, security, and peace in the region.

They note the results of existing bilateral and multilateral forms of cooperation and express their readiness to increase efforts in the economic, scientific, and culrural fields, and in the field of environment, taking due account of the interests of the developing countries in the region, and taking into consideration the work underway in these fields.

They note with satisfaction the positive outcome of the Seminar on economic, scientific, and cultural cooperation in the Mediterranean within the framework of the results of the Valetta Meeting of 1979, held in Venice from 16 to 26 October 1984 in accordance with the relevant provisions and objectives of the Madrid Concluding Document. They welcome the concrete contribution of this Seminar to the development of cooperation in the Mediterranean area 
and they support continued efforts to implement its recommendations as well as those of the Valetta Meeting.

They note the continuing interest of the non-participating Mediterranean States in the CSCE and in efforts with the participating States in strengthening security and promoting cooperation in the Mediterranean. They recognize to this end the need to maintain and amplify their contacts with the non-participating Mediterranean States as initiated by the CSCE and to develop good neighborly relations with all of them, with due regard to reciprocity and in the spirit of the principles contained in the Declaration of Principles guiding relations between participating States of the Final Act.

The participating States,

In conformity with the provisions of the Mediterranean chapters of the Final Act and the Madrid Concluding Document, agree to convene a Meeting on the Mediterranean in order to consider ways and means of further enhancing various aspects of cooperation, including the protection and improvement of the Mediterranean ecosystems, with the aim of widening the scope of their cooperation with the nonparticipating Mediterranean States and contributing to the strengthening of confidence and security in the region.

Representatives of the non-participating Mediterranean States (Algeria, Egypt, Israel, Lebanon, Libya, Morocco, Syria, and Tunisia) and representatives of the competent international organizations (UNESCO, ECE, UNEP,* WHO, ITU, IMO) will be invited to this meeting in accordance with the rules and practices adopted for the previous CSCE Mediterranean follow-up events.

The Meeting will be held in Palma de Mallorca from 24 September to 19 October 1990 . The agenda, timetable, and other organizational modalities will be as set out in Annex VII.

* It is understood that the invitation to UNEP includes ROCC (Regional Oil Combating Center) and MAP (Mediterranean Action Plan). 


\section{THE HELSINKI PROCESS}

The next Follow-up Meeting, to be held in Helsinki, commencing on 24 March 1992, will assess the results achieved at this Meeting.

\section{CO-OPERATION IN HUMANITARIAN AND OTHER FIELDS}

The participating States,

Considering that co-operation in humanitarian and other fields is an essential factor for the development of their relations,

Agreeing that their co-operation in these fields should take place in full respect for the principles guiding relations between participating States as set forth in the Final Act as well as for the provisions in the Madrid Concluding Document and in the present Document pertaining to those principles,

Confirming that, in implementing the provisions concerning co-operation in humanitarian and other fields in the framework of their laws and regulations, they will ensure that those laws and regulations conform with their obligations under international law and are brought into harmony with their CSCE commitments.

Recognizing that the implementation of the relevant provisions of the Final Act and of the Madrid Concluding Document requires continuous and intensified efforts,

Have adopted and will implement the following:

\section{HUMAN CONTACTS}

1. In implementing the human contacts provisions of the Final Act, the Madrid Concluding Document and the present Document, they will fully respect their obligations under international law as referred to in the subchapter of the present Document devoted to principles, in particular that 
everyone shall be free to leave any country, including his own, and to return to his country, as well as their international commitments in this field.

2. They will ensure that their policies concerning entry into their territories are fully consistent with the aims set out in the relevant provisions of the Final Act, the Madrid Concluding Document and the present Document.

3. They will take the necessary steps to find solutions as expeditiously as possible, but in any case within six months, to all applications based on the human contacts provisions of the Final Act and the Madrid Concluding Document, outstanding at the conclusion of the Vienna Follow-up Meeting.

4. Thereafter they will conduct regular reviews in order to ensure that all applications based on the human contacts provisions of the Final Act and of the other afore-mentioned CSCE documents are being dealt with in a manner consistent with those provisions.

5. They will decide upon applications relating to family meetings in accordance with the Final Act and the other afore-mentioned CSCE documents in as short a time as possible and in normal practice within one month.

6. In the same manner they will decide upon applications relating to family reunification or marriage between citizens of different States, in normal practice within three months. 7. In dealing favourably with applications relating to family meetings, they will take due account of the wishes of the applicant, in particular on the timing and sufficiently long duration of such meetings, and on travelling together with other members of his family for joint family meetings.

8. In dealing favourably with applications relating to family meetings, they will also allow visits to and from more distant relatives.

9. In dealing favourably with applications relating to family reunification or marriage between citizens of different States, 


\section{THE HELSINKI PROCESS}

they will respect the wishes of the applicants on the country of destination ready to accept them.

10. They will pay particular attention to the solution of problems involving the reunification of minor children with their parents. In this context and on the basis of the relevant provisions of the Final Act and of the other afore-mentioned CSCE documents, they will ensure

- that an application in this regard submitted while the child is a minor will be dealt with favourably and expeditiously in order to effect the reunification without delay; and

- that adequate arrangements are made to protect the interests and welfare of the children concerned.

11. They will consider the scope for gradually reducing and eventually eliminating any requirement which might exist for travellers to obtain local currency in excess of actuall expenditure, giving priority to persons travelling for the purpose of family meetings. They will accord such persons the opportunity in practice to bring in or to take out with them personal possessions or gifts.

12. They will pay immediate attention to applications for travel of an urgent humanitarian nature and deal with them favourably as follows:

- They will decide within three working days upon applications relating to visits to a seriously ill or dying family member, travel to attend the funeral of a family member or travel by those who have a proven need of urgent medical treatment or who can be shown to be critically or terminally ill.

- They will decide as expeditiously as possible upon applications relating to travel by those who are seriously ill or by the elderly, and other travel of an urgent humanitarian nature.

They will intensify efforts by their local, regional and central authorities concerned with the implementation of the above. 


\section{THE VIENNA CONCLUDING DOCUMENT}

and ensure that charges for giving priority treatment to such applications do not exceed costs actually incurred.

13. In dealing with applications for travel for family meetings, family reunification or marriage between citizens of different States, they will ensure that acts or omissions by members of the applicant's family do not adversely affect the rights of the applicant as set forth in the relevant international instruments.

14. They will ensure that all documents necessary for application based on the human contacts provisions of the Final Act and of the other afore-mentioned CSCE documents are easily accessible to the applicant. The documents will remain valid throughout the application procedure. In the event of a renewed application the documents already submitted by the applicant in connection with previous applications will be taken into consideration.

15. They will simplify practices and gradually reduce administrative requirements for applications based on the human contacts provisions of the Final Act and of the other aforementioned CSCE documents.

16. They will ensure that, when applications based on the human contacts provisions of the Final Act and of the other afore-mentioned CSCE documents are refused for reasons specified in the relevant international instruments, the applicant is promptly provided in writing with an official notification of the grounds on which the decision was based. As a rule and in all cases where the applicant so requests, he will be given the necessary information about the procedure for making use of any effective administrative or judicial remedies against the decision available to him as envisaged in the above-mentioned international instruments. In cases where exist for permanent settlement abroad is involved, this information will be provided as part of the official notification foreseen above.

17. If in this context an individual's application for travel abroad has been refused for reasons of national security, 


\section{THE HELSINKI PROCESS}

they will ensure that, within strictly warranted time limits, any restriction on that individual's travel is as short as possible and is not applied in an arbitrary manner. They will also ensure that the applicant can have the refusal reviewed within six months and, should the need arise, at regular intervals thereafter so that any changes in the circumstances surrounding the refusal, such as the time elapsed since the applicant was last engaged in work or duties involving national security, are taken into account. Before individuals take up work or duties involving national security, they will be formally notified if and how this could affect applications they might submit for such travel. 18. Within one year of the conclusion of the Vienna Followup Meeting they will publish and make easily accessible, where this has not already been done, all their laws and statutory regulations concerning movement by individuals within their territory and travel between States.

19. In dealing favourably with applications based on the human contacts provisions of the Final Act and of the other afore-mentioned CSCE documents, they will ensure that these are dealt with in good time in order, inter alia, to take due account of important family, personal or professional considerations significant for the applicant.

20. They will deal favourably with applications for travel abroad without distinction of any kind, such as race, colour, sex, language, religion, political or other opinion, national or social origin, property, birth, age or other status. They will ensure that any refusal does not affect applications submitted by other persons.

21. They will further facilitate travel on an individual or collective basis for personal or professional reasons and for tourism, such as travel by delegations, groups, and individuals. To this end they will reduce the time for the consideration of applications for such travel to a minimum.

22. They will give serious consideration to proposals for concluding agreements on the issuing of multiple entry visas 
and the reciprocal easing of visa processing formalities, and consider possibilities for the reciprocal abolition of entry visas on the basis of agreements between them.

23. They will consider adhering to the relevant multilateral instruments as well as concluding complementary or other bilateral agreements, if necessary, in order to improve arrangements for ensuring effective consular, legal and medical assistance for citizens of other participating States temporarily on their territory.

24. They will take any necessary measures to ensure that citizens of other participating States temporarily on their territory for personal or professional reasons, inter alia for the purpose of participating in cultural, scientific and educational activities, are afforded appropriate personal safety, where this is not already the case.

25. They will facilitate and encourage the establishment and maintenance of direct personal contacts between their citizens as well as between representatives of their institutions and organizations through travel between States and other means of communications.

26. They will facilitate such contacts and co-operation among their peoples through such measures as direct sports exchanges on a local and regional level, the unimpeded establishment and implementation of town-twinning arrangements, as well as student and teacher exchanges.

27. They will encourage the further development of direct contacts between young people, as well as between governmental and non-governmental youth and student organizations and institutions; the conclusion between such organizations and institutions of bilateral and multilateral arrangements and programmers; and the holding on a bilateral and multilateral basis of educational, cultural and other events and activities by and for young people.

28. They will make further efforts to facilitate travel and tourism by young people, inter alia, by recommending to those of their railway authorities which are members of 


\section{THE HELSINKI PROCESS}

the International Union of Railways (UIC) that they expand the Inter-Rail system to cover all their European networks and by recommending to those of their railway authorities which are not members of the UIC that they consider establishing similar facilities.

29. In accordance with the Universal Postal Convention and the International Telecommunication Convention, they will - guarantee the freedom of transit of postal communication; - ensure the rapid and unhindered delivery of correspondence, including personal mail and parcels;

- respect the privacy and integrity of postal and telephone communications; and

- ensure the conditions necessary for rapid and uninterrupted telephone calls, including the use of international direct dialing systems, where they exist, and their development.

30. They will encourage direct personal contacts between the citizens of their States, inter alia by facilitating individual travel within their countries and by allowing foreigners to meet their citizens as well as, when invited to do so, to stay in private homes.

31. They will ensure that the status of persons belonging to national minorities or regional cultures on their territories is equal to that of other citizens with regard to human contacts under the Final Act and the other afore-mentioned CSCE documents and that these persons can establish and maintain such contacts through travel and other means of communication, including contacts with citizens of other States with whom they share a common national origin or cultural heritage.

32. They will allow believers, religious faiths and their representatives, in groups or on an individual basis, to establish and maintain direct personal contacts and communication with each other, in their own and other countries, inter alia through travel, pilgrimages and participation in assemblies and other religious events. In this context and commen- 
surate with such contacts and events, those concerned will be allowed to acquire, receive and carry with them religious publications and objects related to the practice of their religion or belief.

33. They heard accounts of the Meeting of Experts on Human Contacts held in Bern from 15 April to 26 May 1986. Noting that no conclusions had been agreed upon at the Meeting, they regarded both the frankness of the discussion and the greater degree of openness in the exchanges as welcome developments. In this respect they noted the particular importance of the fact that proposals made at the Meeting had received further consideration at the Vienna Follow-up Meeting.

\section{INFORMATION}

34. They will continue efforts to contribute to an ever wider knowledge and understanding of life in their States, thus promoting confidence between peoples.

They will make further efforts to facilitate the freer and wider dissemination of information of all kinds, to encourage co-operation in the field of information and to improve the working conditions for journalists.

In this connection and in accordance with the International Covenant on Civil and Political Rights, the Universal Declaration of Human Rights and their relevant international commitments concerning seeking, receiving and imparting information of all kinds, they will ensure that individuals can freely choose their sources of information. In this context they will.

- ensure that radio services operating in accordance with the ITU Radio Regulations can be directly and normally received in their states; and

- allow individuals, institutions and organizations, while respecting intellectual property rights, including copyright, to 


\section{THE HELSINKI PROCESS}

obtain, possess, reproduce and distribute information material of all kinds.

To these ends they will remove any restrictions inconsistent with the above-mentioned obligations and commitments.

35. They will take every opportunity offered by modern means of communication, including cable and satellites, to increase the freer and wider dissemination of information of all kinds. They will also encourage co-operation and exchanges between their relevant institutions, organizations and technical experts, and work towards the harmonization of technical standards and norms. They will bear in mind the effects of these modern means of communications on their mass media.

36. They will ensure in practice that official information bulletins can be freely distributed on their territory by the diplomatic and other official missions and consular posts of the other participating States.

37. They will encourage radio and television organizations, on the basis of arrangements between them to broadcast live, especially in the organizing countries, programmes and discussions with participants from different States and to broadcast statements of and interviews with political and other personalities from the partıcipating States.

38. They will encourage radio and television organizations to report on different aspects of life in other participating States and to increase the number of telebridges between their countries.

39. Recalling that the legitimate pursuit of journalists' professional activity will neither render them liable to expulsion nor otherwise penalize them, they will refrain from taking restrictive measures such as withdrawing a journalist's accreditation or expelling him because of the content of the reporting of the journalist or of his information media.

40. They will ensure that, in pursuing this activity, journalists, including those representing media from other partici- 
pating States, are free to seek access to and maintain contacts with public and private sources of information and that their need for professional confidentiality is respected. 41. They will respect the copyright of journalists.

42. On the basis of arrangements between them, where necessary, and for the purpose of regular reporting, they will grant accreditation, where it is required, and multiple entry visas to journalists from other participating States, regardless of their domicile. On this basis they will reduce to a maximum of two months the period for issuing both accreditation and multiple entry visas to journalists.

43. They will facilitate the work of foreign journalists by providing relevant information, on request, on matters of practical concern, such as import regulations, taxation and accommodation.

44. They will ensure that official press conferences and, as appropriate, other similar official press events are also open to foreign journalists, upon accreditation, where this is required.

45. They will ensure in practice that persons belonging to national minorities or regional cultures on their territories can disseminate, have access to, and exchange information in their mother tongue.

46. They agree to convene an Information Forum to discuss improvement of the circulation of, access to and exchange of information; co-operation in the field of information; and the improvement of working conditions for journalists. The Forum will be held in London from 18 April to 12 May 1989. It will be attended by personalities from the participating States in the field of information. The agenda, timetable and other organizational modalities are set out in Annex VIII. 


\section{CO-OPERATION AND EXCHANGES IN THE FIELD OF CULTURE}

47. They will promote and give full effect to their cultural co-operation, inter alia through the implementation of any relevant bilateral and multilateral agreements concluded among them in the various fields of culture.

48. They will encourage non-governmental organization interested in the field of culture, to participate, together with state institutions, in the elaboration and implementation of these agreements and specific projects, as well as in the elaboration of practical measures concerning cultural exchange and co-operation.

49. They will favour the establishment, by mutual agreement, of cultural institutes or centres of other participating States on their territory. Unhindered access by the public to such institutes or centres as well as their normal functioning will be assured.

50. They will assure unhindered access by the public to cultural events organized on their territory by persons or institutions from other participating States and ensure that the organizers can use all means available in the host country to publicize such events.

51. They will facilitate and encourage direct personal contacts in the field of culture, on both an individual and a collective basis, as well as contacts between cultural institutions, associations of creative and performing artists and other organizations in order to increase the opportunities for their citizens to acquaint themselves directly with the creative work in and from other participating States.

52. They will ensure the unimpeded circulation of works of art and other cultural objects, subject only to those restrictions aimed at preserving their cultural heritage which are based on respect for intellectual and artistic property rights or derive from their international commitments on the circulation of cultural property. 
53. They will encourage co-operation between and joint artistic endeavors of persons from different participating states who are engaged in cultural activities; as appropriate, facilitate specific initiatives to this end by such persons, institutions and organizations and encourage the participation of young people in such initiatives. In this context they will encourage meetings and symposia, exhibitions, festivals and tours by ensembles or companies, and research and training programmes in which persons from the other participating States may also freely take part and make their contribution.

54. The replacement of persons or groups invited to participate in a cultural activity will be exceptional and subject to prior agreement by the inviting party.

55. They will encourage the holding of film weeks including, as appropriate, meetings of artists and experts as well as lectures on cinematographic art; facilitate and encourage direct contacts between film directors and producers with a view to co-producing films; and encourage cooperation in the protection of film material and the exchange of technical information and publication about the cinema.

56. They will explore the scope for computerizing bibliographies and catalogues of cultural works and productions in a standard form and disseminating them.

57. They will encourage museums and art galleries to develop direct contacts, inter alia with a view to organizing exhibitions, including loans of works of art, and exchanging catalogues.

58. They will renew their efforts to give effect to the provisions of the Final Act and the Madrid Concluding Document relatir $_{i} . u$ less widely spoken languages. They will also encourage initiatives aimed at increasing the number of translations of literature from and into these languages and improving their quality, in particular by the holding of workshops involving translators, authors and publishers, by the 


\section{THE HELSINKI PROCESS}

publication of dictionaries and, where appropriate, by the exchange of translators through scholarships.

59. They will ensure that persons belonging to national minorities or regional cultures on their territories can maintain and develop their own culture in all its aspects, including language, literature and religion; and that they can preserve their cultural and historical monuments and objects. 60. They heard accounts of the work done and the ideas advanced during the Cultural Forum held in Budapest from 15 October to 25 November 1985 . Noting that no conclusions had been agreed upon at the Forum, they welcomed the fact that many of the useful ideas and proposals put forward there had received renewed consideration at the Vienna Follow-up Meeting and that institutions and organizations in the participating States have based many activities on these ideas. They expressed their appreciation of the significant contributions made to the event by leading personalities in the field of cultural, and noted, in the light of the experience gained, the importance of securing, both inside and outside future meetings of this nature, arrangements which would permit a freer and more spontaneous discussion.

61. Taking duly into account the originality and diversity of their respective cultures, they will encourage efforts to explore common features and to foster greater awareness of their cultural heritage. Accordingiy they will encourage initiatives which may contribute to a better knowledge of the cultural heritage of the other participating States in all its forms, including regional aspects and folk art.

62. They agree to convene a Symposium on the Cultural Heritage of the CSCE participating States. The symposium will take place in Cracow from 28 May to 7 June 1991. It will be attended by scholars and other personalities from the participating States who are engaged in cultural activities. The agenda, timetable and other organizational modalities are set out in Annex IX. 


\section{COOPERATION AND EXCHANGES IN THE FIELD OF EDUCATION}

63. They will ensure access by all to the various types and levels of education without discrimination as to race, colour, sex, language, religion, political or other opinion, national or social origin, property, birth or other status. 64. In order to encourage wider cooperation in science and education, they will facilitate unimpeded communication between universities and other institutions of higher education and research. They will also facilitate direct personal contacts, including contacts through travel, between scholars, scientists and other persons active in these fields.

65. In this context they will also ensure unimpeded access by scholars, teachers and students from the other participating States to open information material available in public archives, libraries, research institutes and similar bodies.

66. They will facilitate exchanges of schoolchildren between their countries on the basis of bilateral arrangements, where necessary, including meeting and staying with families of the host country in their homes, with the aim of acquainting schoolchildren with life, traditions and education in other participating States.

67. They will encourage their relevant government agencies or educational institutions to include, as appropriate, the Final Act as a whole in the curricula of schools and universities.

68. They will ensure that persons belonging to national minorities or regional cultures on their territories can give and receive instruction on their own culture, including instruction through parental transmission of language, religion and cultural identity to their children.

69. They will encourage their radio and television organizations to inform each other of the educational programmes they produce and to consider exchanging such programmes. 


\section{THE HELSINKI PROCESS}

70. They will encourage direct contacts and cooperation between governmental institutions or organizations in the field of education and science.

71. They will encourage further cooperation and contacts between specialized institutions and experts in the field of education and rehabilitation of handicapped childreri.

\section{HUMAN DIMENSION OF THE CSCE}

The participating States,

Recalling the undertakings entered into in the Final Act and in other CSCE documents concerning respect for all human rights and fundamental freedoms, human contacts and other issues of a related humanitarian character,

Recognizing the need to improve the implementation of their CSCE commitments and their co-operation in these areas which are hereafter referred to as the human dimension of the CSCE,

Have, on the basis of the principles and provisions of the Final Act and of other relevant CSCE documents, decided:

1. to exchange information and respond to requests for information and to representations made to them by other participating States on questions relating to the human dimension of the CSCE. Such communications may be forwarded through diplomatic channels or be addressed to any agency designated for these purposes;

2. to hold bilateral meetings with other participating States that so request, in order to examine questions relating to the human dimension of the CSCE, including situations and specific cases with a view to resolving them. The date and place of such meeting will be arranged by mutual agreement through diplomatic channels;

3. that any participating State which deems it necessary may bring situations and cases in the human dimensions of the CSCE, including those which have been raised at 
the bilateral meetings described in paragraph 2 , to the attention of other participating States through diplomatic channels;

4. that any participating State which deems it necessary may provide information on the exchange of information and the responses to its requests for information and to representations (paragraph 1) and on the results of the bilateral meetings (paragraph 2), including information concerning situations and specific cases, at the meetings of the Conference on the Human Dimension as well as at the main CSCE Follow-up Meetings.

The participating States decide further to convene a Conference on the Human Dimension of the CSCE in order to achieve further progress concerning respect for all human rights and fundamental freedoms, human contacts and other issues of a related humanitarian characier. The Conference will hold three meetings before the next CSCE Follcwup meeting

The Conference will:

- review developments in the human dimension of the CSCE including the implementation of the relevant CSCE commitments;

- evaluate the functioning of the procedure described in paragraphs 1 to 4 and discuss the information provided according to paragraph 4 ;

- consider practical proposals for new measures aimed at improving the implementation of the commitments relating to the human dimension of the CSCE and enhancing the effectiveness of the procedures described in paragraphs 1 to 4 .

On the basis of these proposals, the Conference will consider adopting new measures.

The first Meeting of the Conference will be held in Paris from 30 May to 23 June 1989.

The second Meeting of the Conference will be held in Copenhagen from 5 June to 29 June 1990. 


\section{THE HELSINKI PROCESS}

The third Meeting of the Conference will be held in Moscow from 10 September to 4 October 1991.

The agenda, timetable and other organizational modalities are set out in Annex X.

The next main CSCE Follow-up Meeting, to be held in Helsinki, commencing on 24 March 1992, will assess the functioning of the procedures set out in paragraphs 1 to 4 above and the progress made at the Meetings of the Conference on the Human Dimension of the CSCE. It will consider ways of further strengthening and improving these procedures and will take appropriate decisions.

\section{FOLLOW-UP TO THE CONFERENCE}

In conformity with the relevant provisions of the Final Act and with their resolve and commitment to continue the multilateral process initiated by the CSCE, the participating States will hold further meetings regularly among their representatives.

The fourth main Follow-up meeting will be held in Helsinki, commencing on 24 March 1992.

The agenda, work programme and modalities of the main Vienna Meeting will be applied mutatis mutandis to the main Helsinki Meeting, unless other decisions on these questions are taken by the preparatory meeting mentioned below.

For the purpose of making the adjustments to the agenda, work programme and modalities applied at the main Vienna Meeting, a preparatory meeting will be held in Helsinki, commencing on 10 March 1992. It is understood that in this context adjustments concern those items requiring change as a result of the change in date and place, the drawing of lots, and the mention of the other meetings held in conformity with the decisions of the Vienna Meeting 1986. The duration of the preparatory meeting shall not exceed two weeks. 


\section{THE VIENNA CONCLUDING DOCUMENT}

The agenda, work programme and modalities for CSCE follow-up meetings mentioned in this document have been prepared by the main Vienna Meeting. The results of these meetings will be taken into account, as appropriate, at the main Helsinki Meeting.

All the meetings referred to in this chapter will be held in conformity with paragraph 4 of the chapter on "Follow-up to the Conference" of the Final Act.

The participating States examined the scope for rationalizing the modalities for future CSCE follow-up meetings, for enhancing their effectiveness and for ensuring the best possible use of resources. In the light of their examination and in connection with the steps taken at the main Vienna Meeting, including the drawing up of mandates annexed to this document, they decided:

- to dispense with preparatory meetings unless otherwise agreed;

- bearing in mind the purpose of the meeting, to limit the number of subsidiary working bodies meeting simultaneously to the lowest possible;

- to limit the duration of meetings, unless otherwise agreed, to a period not exceeding four weeks;

- in the case of meetings to which non-governmental participants are invited to contribute, to make maximum use of the possibility of having informal meetings in order to allow for a more spontaneous discussion;

- to observe to the same extent as the host country its national day.

The main Helsinki Meeting will review these arrangements and other modalities in the light of experience, with a view to making any improvements which may be necessary.

The Government of Austria is requested to transmit the present document to the Secretary-General of the United Nations, to the Director-General of UNESCO and in the Executive Secretary of the United Nations Economic Com- 
THE HELSINKI PROCESS

mission for Europe and to other international organizations mentioned in this document. The Government of Austria is also requested to transmit the present document to the Governments of the non-participating Mediterranean States.

The text of this document will be published in each participating State, which will disseminate it and make it known as widely as possible.

The representatives of the participating States express their profound gratitude to the people and Government of Austria for the excellent organization of the Vienna Meeting and warm hospitality extended to the delegations which participated in the Meeting.

Vienna, 15 January 1989 


\section{Appendix E \\ Charter of Paris for a New Europe}

\section{PARIS 1990}

Meeting of the Heads of State or Government of the participating States of the Conference on Security and Co-operation in Europe (CSCE): Austria, Belgium, Bulgaria, Canada, Cyprus, Czech and Slovak Federal Republic, Denmark, Finland, France, Germany, Greece, Holy See, Hungary, Iceland, Ireland, Italy-European Community, Liechtenstein, Luxembourg, Malta, Monaco, Netherlands, Norway, Poland, Portugal, Romania, San Marino, Spain, Sweden, Switzerland, Turkey, Union of Soviet Socialist Republics, United Kingdom, United States of America and Yugoslavia

Paris, 19-21 November 1990

\section{A New Era of Democracy, Peace and Unity}

We, the Heads of State or Government of the States participating in the Conference on Security and Co-operation in Europe, have assembled in Paris at a time of profound change and historic expectations. The era of confrontation and division of Europe has ended. We declare that henceforth our relations will be founded on respect and co-operation.

Europe is liberating itself from the legacy of the past. The courage of men and women, the strength of the will 


\section{THE HELSINKI PROCESS}

of the peoples and the power of the ideas of the Helsinki Final Act have opened a new era of democracy, peace and unity in Europe.

Ours is a time for fulfilling the hopes and expectations our peoples have cherished for decades: steadfast commitment to democracy based on human rights and fundamental freedoms; prosperity through economic liberty and social justice; and equal security for all our countries.

The Ten Principles of the Final Act will guide us towards this ambitious future, just as they have lighted our way towards better relations for the past fifteen years. Full implementation of all CSCE commitments must form the basis for the initiatives were are now taking to enable our nations to live in accordance with their aspirations.

\section{Human Rights, Democracy and Rule of Law}

We undertake to build, consolidate and strengthen democracy as the only system of government of our nations. In this endeavour, we will abide by the following:

Human rights and fundamental freedoms are the birthright of all human beings, are inalienable and are guaranteed by law. Their protection and promotion is the first responsibility of government. Respect for them in an essential safeguard against an over-mighty State. Their observance and full exercise are the foundation of freedom, justice and peace.

Democratic government is based on the will of the people, expressed regularly through free and fair elections. Democracy has as its foundation respect for the human person and the rule of law. Democracy is the best safeguard of freedom of expression, tolerance of all groups of society, and equality of opportunity for each person. 
THE CHARTER OF PARIS

Democracy, with its representative and pluralist character, entails accountability to the electorate, the obligation of public authorities to comply with the law and justice administered impartially. No one will be above the law.

We affirm that, without discrimination,

every individual has the right to:

freedom of thought, conscience and religion or belief, freedom of expression,

freedom of association and peaceful assembly, freedom of movement;

no one will be:

subject to arbitrary arrest or detention,

subject to torture or other cruel, inhuman or degrading treatment or punishment;

everyone also has the right:

to know and act upon his rights.

to participate in free and fair elections,

to fair and public trial if charged with an offence,

to own property alone or in assuciation and to exercise individual enterprise,

to enjoy his economic, social and cultural rights.

We affirm that the ethnic, cultural, linguistic and religious identity of national minorities will be protected and that persons belonging to national minorities have the right freely to express, preserve and develop that identity without any discrimination and in full equality before the law.

We will ensure that everyone will enjoy recourse to effective remedies, national or international, against any violation of his rights. 


\section{THE HELSINKI PROCESS}

Full respect for these precepts is the bedrock on which we will seek to construct the new Europe.

Our States will co-operate and support each other with the aim of making democratic gains irreversible.

\section{Economic Liberty and Responsibility}

Economic liberty, social justice and environmental responsibility are indispensable for prosperity.

The free will of the individual, exercised in democracy and protected by the rule of law, forms the necessary basis for successful economic and social development. We will promote economic activity which respects and upholds human dignity.

Freedom and political pluralism are necessary elements in our common objective of developing market economies towards sustainable economic growth, prosperity, social justice, expanding employment and efficient use of economic resources. The success of the transition to market economy by countries making efforts to this effect is important and in the interest of us all. It will enable us to share a higher level of prosperity which is our common objective. We will co-operate to this end.

Preservation of the environment is a shared responsibility of all our nations. While supporting national and regional efforts in this field, we must also look to the pressing need for joint action on a wider scale.

\section{Friendly Relations Among Participating States}

Now that a new era is drawing in Europe, we are determined to expand and strengthen friendly relations and co-operation among the States of Europe, the United States 
THE CHARTER OF PARIS

of America and Canada, and to promote friendship among our peoples.

To uphold and promote democracy, peace and unity in Europe, we solemnly pledge our full commitment to the Ten Principles of the Helsinki Final Act. We affirm the continuing validity of the Ten Principles and our determination to put them into practice. All the Principles apply equally and unreservedly, each of them being interpreted taking into account the others. They form the basis for our relations.

In accordance with our obligations under the Charter of the United Nations and commitments under the Helsinki Final Act, we renew our pledge to refrain from the threat or use of force against the territorial integrity or political independence of any State, or from acting in any other manner inconsistent with the principles or purposes of those documents. We recall that non-compliance with obligations under the Charter of the United Nations constitutes a violation of international law.

We reaffirm our commitment to settle disputes by peaceful means. We decide to develop mechanisms for the prevention and resolution of conflicts among the participating States.

With the ending of the division of Europe, we will strive for a new quality in our security relations while fully respecting each other's freedom of choice in that respect. Security is indivisible and the security of every participating State is inseparably linked to that of all the others. We therefore pledge to co-operate in strengthening confidence and security among us and in promoting arms control and disarmament.

We welcome the Joint Declaration of Twenty-Two States on the improvement of their relations. 


\section{THE HELSINKI PROCESS}

Our relations will rest on our common adherence to democratic values and to human rights and fundamental freedoms. We are convinced that in order to strengthen peace and security among our States, the advancement of democracy, and respect for and effective exercise of human rights, are indispensable. We reaffirm the equal rights of peoples and their right to self-determination in conformity with the Charter of the United Nations and with the relevant norms of international law, including those relating to territorial integrity of States.

We are determined to enhance political consultation and to widen co-operation to solve economic, social, environmental, cultural and humanitarian problems. This common resolve and our growing interdependence will help to overcome the mistrust of decades, to increase stability and to build a united Europe.

We want Europe to be a source of peace, open to dialogue and to co-operation with other countries, welcoming exchanges and involved in the search for common responses to the challenges of the future.

\section{Security}

Friendly relations among us will benefit from the consolidation of democracy and improved security.

We welcome the signature of the Treaty on Conventional Armed Forces in Europe by twenty-two participating States, which will lead to lower levels of armed forces. We endorse the adoption of a substantial new set of Confidence- and Security-building Measures which will lead to increased transparency and confidence among all participating States. These are important steps towards enhanced stability and security in Europe. 
The unprecedented reduction in armed forces resulting from the Treaty on Conventional Armed Forces in Europe, together with new approaches to security and co-operation within the CSCE process, will lead to a new perception of security in Europe and a new dimension in our relations. In this context we fully recognize the freedom of States to choose their own security arrangements.

\section{Unity}

Europe whole and free is calling for a new beginning. We invite our peoples to join in this great endeavor.

We note with great satisfaction the Treaty on the Final Settlement with respect to Germany signed in Moscow on 12 September 1990 and sincerely welcome the fact that the German people have united to become one State in accordance with the principles of the Final Act of the Conference on Security and Co-operation in Europe and in full accord with their neighbors. The establishment of the national unity of Germany is an important contribution to a just and lasting order of peace for a united, democratic Europe aware of its responsibility for stability, peace and co-operation.

The participation of both North American and European States is a fundamental characteristic of the CSCE; it underlies its past achievements and is essential to the future of the CSCE process. An abiding adherence to shared values and our common heritage are the ties which bind us together. With all the rich diversity of our nations, we are united in our commitment to expand our co-operation in all fields. The challenges confronting us can only be met by common action, co-operation and solidarity. 


\section{THE HELSINKI PROCESS}

\section{The CSCE and the World}

The destiny of our nations is linked to that of all other nations. We support fully the United Nations and the enhancement of its role in promoting international peace, security and justice. We reaffirm our commitment to the principles and purposes of the United Nations as enshrined in the Charter and condemn all violations of these principles. We recognize with satisfaction the growing role of the United Nations in world affairs and its increasing effectiveness, fostered by the improvement in relations among our States.

Aware of the dire needs of a great part of the world, we commit ourselves to solidarity with all other countries. Therefore, we issue a call from Paris today to all the nations of the world. We stand ready to join with any and all States in common efforts to protect and advance the community of fundamental human values.

\section{Guidelines for the Future}

Proceeding from our firm commitment to the full implementation of all CSCE principles and provisions, we now resolve to give a new impetus to a balanced and comprehensive development of our co-operation in order to address the needs and aspirations of our peoples.

\section{Human Dimension}

We declare our respect for human rights and fundamental freedoms to be irrevocable. We will fully implement and build upon the provisions relating to the human dimension of the CSCE.

Proceeding from the Document of the Copenhagen Meeting of the Conference on the Human Dimension, we will co-operate to strengthen democratic institutions and to 


\section{THE CHARTER OF PARIS}

promote the application of the rule of law. To that end, we decide to convene a seminar of experts in Oslo from 4 to 15 November 1991.

Determined to foster the rich contribution of national minorities to the life of our societies, we undertake further to improve their situation. We reaffirm our deep conviction that friendly relations among our peoples, as well as peace, justice, stability and democracy, require that the ethnic, cultural, linguistic and religious identify of national minorities be protected and conditions for the promotion of that identity be created. We declare that questions related to national minorities can only be satisfactorily resolved in a democratic political framework. We further acknowledge that the rights of persons belonging to national minorities must be fully respected as part of universal human rights. Being aware of the urgent need for increased co-operation on, as well as better protection of, national minorities, we decide to convene a meeting of experts on national minorities to be held in Geneva from 1 to 19 July 1991.

We express our determination to combat all forms of racial and ethnic hatred, anti-semitism, xenophobia and discrimination against anyone as well as persecution on religious and ideological grounds.

In accordance with our CSCE commitments, we stress that free movement and contacts among our citizens as well as the free flow of information and idea are crucial for the maintenance and development of free societies and flourishing cultures. We welcome increased tourism and visits among our countries.

The human dimension mechanism has proved its usefulness, and we are consequently determined to expand it to include new procedures involving, inter alia, the services of experts or a roster of eminent persons experienced in 


\section{THE HELSINKI PROCESS}

human rights issues which could be raised under the mechanism. We shall provide, in the context of the mechanism, for individuals to be involved in the protection of their rights. Therefore, we undertake to develop further our commitments in this respect, in particular at the Moscow meeting of the Conference on the Human Dimension, without prejudice to obligations under existing international instruments to which our States may be parties.

We recognize the important contribution of the Council of Europe to the promotion of human rights and the principles of democracy and the rule of law as well as to the development of cultural co-operation. We welcome moves by several participating States to join the Council of Europe and adhere to its European Convention on Human Rights. We welcome as well the readiness of the Council of Europe to make its experience available to the CSCE.

\section{Security}

The changing political and military environment in Europe opens new possibilities for common efforts in the field of military security. We will build on the important achievements attained in the Treaty on Conventional Armed Forces in Europe and in the Negotiations on Confidence- and Security-building Measures. We undertake to continue the CSBM negotiations under the same mandate and to seek to conclude them no later than the follow-up meeting of the CSCE to be held in Helsinki in 1992. We also welcome the decision of the participating States concerned to continue the CFE negotiation under the same mandate and to seek to conclude it no later than the Helsinki Follow-up Meeting. Following a period for national preparations, we look forward to a more structured co-operation among all participating States on security matters, and to discussions and consultations among the thirty-four participating States aimed 
at establishing by 1992 , from the conclusion of the Helsinki follow-up meeting, new negotiations on disarmament and confidence and security building open to all participating States.

We call for the earliest possible conclusion of the Convention on an effectively verifiable, global and comprehensive ban on chemical weapons, and we intend to be original signatories $\cdot \rightarrow$ it.

We reaffirm the importance of the Open Skies initiative and call for the successful conclusion of the negotiations as soon as possible.

Although the threat of conflict in Europe has diminished, other dangers threaten the stability of our societies. We are determined to co-operate in defending democratic institutions against activities which violate the independence, sovereign equality or territorial integrity of the participating States. These include illegal activities involving outside pressure, coercion and subversion.

We unreservedly condemn, as criminal, all acts, methods and practices of terrorism and express our determination to work for its eradication both bilaterally and through multilateral co-operation. We will also join together in combating illicit trafficking in drugs.

Being aware that an essential complement to the duty of States to refrain from the threat or use of force is the peaceful settlement of disputes, both being essential factors for the maintenance and consolidation of international peace and security, we will not only seek effective ways of preventing, through political means, conflicts which may yet emerge, but also define, in conformity with international law, appropriate mechanisms for the peaceful resolution of any disputes which may arise. Accordingly, we undertake to seek new forms of co-operation in this area, in particular 


\section{THE HELSINKI PROCESS}

a range of methods for the peaceful settlement of disputes, including mandatory third-party involvement. We stress that full use should be made in this context of the opportunity of the Meeting on the Peaceful Settlement of Disputes which will be convened in Valletta at the beginning of 1991. The Council of Ministers for Foreign Affairs will take into account the Report of the Valletta Meeting.

\section{Economic Co-operation}

We stress that economic co-operation based on market economy constitutes an essential element of our relations and will be instrumenta! in the construction of a prosperous and united Europe. Democratic institutions and economic liberty foster economic and social progress. as recognized in the Document of the Bonn Conference on Economic Co-operation, the results of which we strongly support.

We underline that co-operation in the economic field, science and technology is now an important pillar oi the CSCE. The participating States should periodically review progress and give new impulses in these fields.

We are convinced that our overall economic co-operation should be expanded, free enterprise encouraged and trade increased and diversified according to GATT rules. We will promote social justice and progress and further the welfare of our peoples. We recognize in this context the importance of effective policies to address the problem of unemployment.

We reaffirm the need to continue to support democratic countries in transition tow ards the establishment of market economy and the creation of the basis for self-sustained economic and social growth, as already undertaken by the Group of twenty-four countries. We further underline the necessity of their increased integration, involving the accept- 
ance of disciplines as well as benefits, into the international economic and financial system.

We consider that increased emphasis on economic cooperation within the CSCE process should take into account the interests of developing participating States.

We recall the link between respect for and promotion of human rights and fundamental freedoms and scientific progress. Co-operation in the field of science and technology will play an essential role in economic and social development. Therefore, it must evolve towards a greater sharing of appropriate scientific and technological information and knowledge with a view to overcoming the technological gap which exists among the participating States. We further encourage the participating States to work together in order to develop human potential and the spirit of free enterprise.

We are determined to give the necessary impetus to co-operation among our States in the fields of energy, transport and tourism for economic and social development. We welcome, in particular, practical steps to create optimal conditions for the economic and rational development of energy resources, with due regard for environmental considerations.

We recognize the important role of the European Community in the political and economic development of Europe. International economic organizations such as the United Nations Economic Commission for Europe (ECE), the Bretton Woods Institutions, the Organisation for Economic Co-operation and Develepment (OECD), the European Free Trade Association (EFTA) and the International Chamber of Commerce (ICC) also have a significant task in promoting economic co-operation. which will be further enhanced by the establishment of the European Bank for Reconstruction and Development (EBRD). In order to pursue our objectives, we stress the necessity for effective co-ordination of 
THE HELSINKI PROCESS

the activities of these organizations and emphasize the need to find methods for all our States to take part in these activities.

\section{Environment}

We recognize the urgent need to tackle the problems of the environment and the importance of individual and co-operative efforts in this area. We pledge to intensify our endeavours to protect and improve our environment in order to restore and maintain a sound ecological balance in air, water and soil. Therefore, we are determined to make full use of the CSCE as a framework for the formulation of common environmental commitments and objectives, and thus to pursue the work reflected in the Report of the Sofia Meeting on the Protection of the Environment.

We emphasize the significant role of a well-informed society in enabling the public and individuals to take initiatives to improve the environment. To this end, we commit ourselves to promoting public awareness and education on the environment as well as the public reporting of the environmental impact of policies, projects and programmes.

We attach priority to the introduction of clean and low-waste technology, being aware of the need to support countries which do not yet have their own means for appropriate measures.

We underine that environmental policies should be supported by appropriate legislative measures and administrative structures to ensure their effective implementation.

We stress the need for new measures providing for the systematic evaluation of compliance with the existing commitments and, moreover, for the development of more ambitious commitments with regard to notification and ex- 
change of information about the state of the environment and potential environmental hazards. We also welcome the creation of the European Environment Agency (EEA).

We welcome the operational activities, problem-oriented studies and policy reviews in various existing international organizations engaged in the protection of the environment, such as the United Nations Environment Programme (UNEP), the United Nations Economic Commission for Europe (ECE) and the Organisation for Economic Co-operation and Development (OECD). We emphasize the need for strengthening their co-operation and for their efficient coordination.

\section{Culture}

We recognize the essential contribution of our common European culture and our shared values in overcoming the division of the continent. Therefore, we underline our attachment to creative freedom and to the protection and promotion of our cultural and spiritual heritage, in all its richness and diversity.

In view of the recent changes in Europe, we stress the increased importance of the Cracow Symposium and we look forward to its consideration of guidelines for intensified co-operation in the field of culture. We invite the Council of Europe to contribute to this Symposium.

In order to promote greater familiarity amongst our peoples, we favour the establishment of cultural centres in cities of other participating States as well as increased cooperation in the audio-visual field and wider exchange in music, theatre, literature and the arts.

We resolve to make special efforts in our national policies to promute better understanding, in particular among 


\section{THE HELSINKI PROCESS}

young people, through cultural exchanges, co-operation in all fields of education and, more specially, through teaching and training in the languages of other participating States. We intend to consider first results of this action at the Helsinki Follow-up Meeting in 1992.

\section{Migrant Workers}

We recognize that the issues of migrant workers and their families legally residing in host countries have economic, cultural and social aspects as well as their human dimension. We reaffirm that the protection and promotion of their rights, as well as the implementation of relevant international obligations, is our common concern.

\section{Mediterranean}

We consider that the fundamental political changes that have occurred in Europe have a positive relevance to the Mediterranean region. Thus, we will continue efforts to strengthen security and co-operation in the Mediterranean as an important factor for stability in Europe. We welcome the Report of the Palma de Mallorca Meeting on the Mediterranean, the results of which we all support.

We are concerned with the continuing tensions in the region, and renew our determination to intensify efforts towards finding just, viable and lasting solutions, through peaceful means, to outstanding crucial problems, based on respect for the principles of the Final Act.

We wish to promote favourable conditions for a harmonious development and diversification of relations with the non-participating Mediterranean States. Enhanced co-operation with these States will be pursued with the aim of promoting economic and social development and thereby 
enhancing stability in the region. To this end, we will strive together with these countries towards a substantial narrowing of the prosperity gap between Europe and its Mediterranean neighbours.

\section{Non-governmental Organizations}

We recall the major role that non-governmental organizations, religious and other groups and individuals have played in the achievement of the objectives of the CSCE and will further facilitate their activities for the implementation of the CSCE commitments by the participating States. These organizations, groups and individuals must be involved in an appropriate way in the activities and new structures of the CSCE in order to fulfil their important tasks.

\section{New Structures and Institutions of the CSCE Process}

Our common efforts to consolidate respect for human rights, democracy and the rule of law, to strengthen peace and to promote unity in Europe a new quality of political dialogue and co-operation and thus development of the structures of the CSCE.

The intensification of our consultations at all levels is of prime importance in shaping our future relations. To this end, we decide on the following:

We, the Heads of State or Government, shall meet next time in Helsinki on the occasion of the CSCE Followup Meeting 1992. Thereafter, we will meet on the occasion of subsequent follow-up meetings. 


\section{THE HELSINKI PROCESS}

Our Ministers of Foreign Affairs will meet, as a Council, regularly and at least once a year. These meetings will provide the central forum for political consultations with the CSCE process. The Council will consider issues relevant to the Conference on Security and Co-operation in Europe and take appropriate decisions.

The first meeting of the Council will take place in Berlin.

A Committee of Senior Officials will prepare the meetings of the Council and carry out its decisions. The Committee will review current issues and may take appropriate decisions, including in the form of recommendations to the Council.

Additional meetings of the representatives of the participating States may be agreed upon to discuss questions of urgent concern.

The Council will examine the development of provisions for convening meetings of the Committee of Senior Officials in emergency situations.

Meetings of other Ministers may also be agreed by the participating States.

In order to provide administrative support for these consultations we establish a Secretariat in Prague.

Follow-up meetings of the participating States will be held, as a rule, every two years to allow the participating States to take stock of developments, review the implementation of their commitments and consider further steps in the CSCE process. 
THE CHARTER OF PARIS

We decide to create a Conflict Prevention Centre in Vienna to assist the Council in reducing the risk of conflict.

We decide to establish an Officer for Free Elections in Warsaw to facilitate contacts and the exchange of information on elections within participating States.

Recognizing the important role parliamentarians can play in the CSCE process, we call for greater parliamentary involvement in the CSCE, in particular through the creation of a CSCE parliamentary assembly, involving members of parliaments from all participating States. To this end, we urge that contacts be pursued at parliamentary level to discuss the field of activities, working methods and rules of procedure of such a CSCE parliamentary structure, drawing on existing experience and work already undertaken in this field.

We ask our Ministers for Foreign Affairs to review this matter on the occasion of their first meeting as a Council.

Procedural and organizational modalities relating to certain provisions contained in the Charter of Paris for a New Europe are set out in the Supplementary Document which is adopted together with the Charter of Paris.

We entrust to the Council the further steps which may be required to ensure the implementation of decisions contained in the present document, as well as in the Supplementary Document, and to consider further efforts for the strengthening of security and co-operation in Europe. The 


\section{THE HELSINKI PROCESS}

Council may adopt any amendment to the supplementary document which it may deem appropriate.

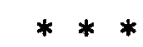

The original of the Charter of Paris for a New Europe, drawn up in English, French, German, Italian, Russian and Spanish, will be transmitted to the Government of the French Republic, which will retain it in its archives. Each of the participating States will receive from the Government of the French Republic a true copy of the Charter of Paris.

The text of the Charter of Paris will be published in each participating State, which will disseminate it and make it known as widely as possible.

The Government of the French Republic is requested to transmit to the Secretary-General of the United Nations the text of the Charter of Paris for a New Europe which is not eligible for registration under Article 102 of the Charter of the United Nations, with a view to its circulation to all the members of the Organization as an official document of the United Nations.

The Government of the French Republic is also requested to transmit the text of the Charter of Paris to all the other international organizations mentioned in the text.

Wherefore, we, the undersigned High Representatives of the participating States, mindful of the high political significance we attach to the results of the Summit Meeting, and declaring our determination to act in accordance with the provisions we have adopted, have subscribed our signatures below: 
THE CHARTER OF PARIS

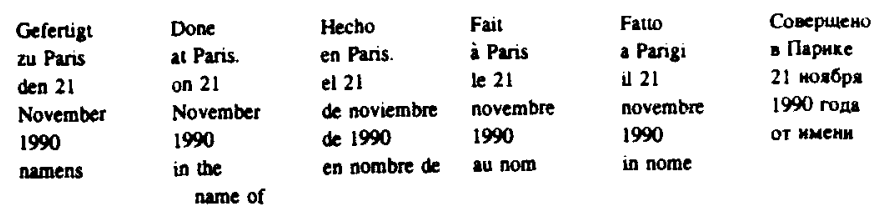

THE FEDERAL REPUBLIC OF GERMANY

Helmut KOHL

Federal Chancellor

THE UNITED STATES OF AMERICA

George BUSH

President of the United States of America

THE REPUBLIC OF AUSTRIA

Franz VRANITZKY

Federal Chancellor

THE KINGDOM OF BELGIUM

Wilfried MARTENS

Prime Minister

THE REPUBLIC OF BULGARIA

Jelyu JELEV

President of the Republic

\section{CANADA}

Martin Brian MULRONEY

Prime Minister

THE REPUBLIC OF CYPRUS

George VASSILIOU

President

THE KINGDOM OF DENMARK

Poul SCHLÜTER 
THE HELSINKI PROCESS

Prime Minister

THE KINGDOM OF SPAIN

Felipe GONZALEZ MARQUEZ

Prime Minister

THE REPUBLIC OF FINLAND

Mauno KOIVISTO

President of the Republic

THE FRENCH REPUBLIC

Francois MITTERRAND

President of the French Republic

THE UNITED KINGDOM OF GREAT BRITAIN AND NORTHERN IRELAND

The Rt. Hon. Margaret THATCHER, F.R.S., M.P.

Prime Minister, First Lord of the Treasury and Minister for the Civil Service

THE HELLENIC REPUBLIC

Constantin MITSOTAKIS

Prime Minister

THE REPUBLIC OF HUNGARY

József ANTALL

Prime Minister

IRELAND

Charles J. HAUGHERY, T.D.

Taoiseach

THE REPUBLIC OF ICELAND

Steingrimur HERMANNSSON

Prime Minister

THE ITALIAN REPUBLIC EUROPEAN COMMUNITIES Giulio ANDREOTTI 
President of the Council of Ministers of the Italian Republic and in his capacity as current President of the Council of the European Communities Jacques DELORS

President of the Commission of the European Communities

THE PRINCIPALITY OF LIECHTENSTEIN

Hans BRUNHART

Head of Government

THE GRAND DUCHY OF LUXEMBOURG

Jacques SANTER

Prime Minister

MALTA

Edward FENECH ADAMI

Prime Minister

THE PRINCIPALITY OF MONACO

Jean AUSSEIL

Minister of State of the Principality

THE KINGDOM OF NORWAY

Gro Harlem BRUNDTLAND

Prime Minister

THE KINGDOM OF THE NETHERLANDS

Rudd F.M. LUBBERS

Prime Minister

THE REPUBLIC OF POLAND

Tadeusz MAZOWIECKI

President of the Council of Ministers

THE PORTUGUESE REPUBLIC

Anibal CAVACO SILVA

Prime Minister 
THE HELSINKI PROCESS

ROMANIA

Ion ILIESCU

President of Romania

THE REPUBLIC OF SAN MARINO

Gabriele GATTI

Secretary of State for Foreign and Political Affairs

THE HOLY SEE

Son Eminence

Le Cardinal Agostino CASAROLI

Secretary of State of His Holiness

THE KINGDOM OF SWEDEN

Ingvar CARLSSON

Prime Minister

THE SWISS CONFEDERATION

Arnold KOLLER

President of the Confederation, Head of the Federal Depart-

ment of Justice and Police

THE CZECH AND SLOVAK FEDERAL REPUBLIC

Vaclav HAVEL

President of the Czech and Slovak Federal Republic

THE REPUBLIC OF TURKEY

Turgut ÖZAL

President of the Republic

THE UNION OF SOVIET SOCIALIST REPUBLICS

M. GORBATCHEV

President of the Union of Soviet Socialist Republics

THE SOCIALIST FEDERAL REPUBLIC OF YUGO-

SLAVIA

Borisav JOVIC 
THE CHARTER OF PARIS

President of the Presidency of the Socialist Federal Republic of Yugoslavia 


\section{Notes}

1. US Depanment of State, American Foreign Policy. 1950 1955: Basic Documents. Volume II (Washington: Gov. ernment Printing Offke. 195?), pp 1855-1858

2 US Department of State, Foreign Ministers Meeting. Berlin Discussions. Januan 25-Februan 18. 1954. Publicauon 5394 (Washingtion Guvernment Prinung Office. 1954). pp $164-170$

3. US Deparument of State. The Conference on Securin and Couperation in Europe (CSCE). Public Starements and Documents 1954-1986 (Wakhington Government Pnnung Orfuce, (926), p v

+ Ibod

9 US Department of Staic, Amenian Foreign Policy. Current Daxuments. Issi. Publication 8495 (Washington Government Printeng Offike. 1464, pp 3:1-323

- LS Deparmeni of State. Dow uments on llisur. mament. 1 sos 1 Washington Covernment Ptinting Orfice. 1970). po 100 108

7 US Department of State. Aullefin. Ami 28. 1969. pp. $34+150$

1. Bullotin idecembet 29. 19691, 6:7

9 US Department of Siale. Mruments on Germani.

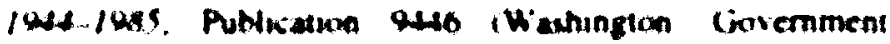
Printing Orfice. 10ns). Po 1102-110s

11) Golletin iJanuary 1. 1972). 1-5

11 Buliatin i June 26. 1972, 999-00:

12 Aullotin iDecember 4 19721. 6ho

19 Dexumenes an Cormans. 1215-121?

14 Eicerpis from a spech by Ambarudo Waren Zimmermann. "The Helunk, Ptoces Intereals and Pros. 


\section{THE HELSINKI PROCESS}

pects," National Leadershup Forum. Georgetoun Universit) Center for Strategic and International Siudies, Mal 16, 1985

15. John J. Maresia. To Helsinki. The Conference on Securin and Cooperation in Europe. 1973-1975 (Durham and London Duke Liniversily Press, 1987). p. 25

10. Publuc Papers of the Presidents of the Unised Stutes Gerulu $R$ Ford 1975 (W'ashungton Government Prnnung Offuce, 1975), p 1031

17 lbad, 1033

Is Ibud. Ius!

19 Jonathan Luxmoure, The Helsinds Agreement Das. logue or Delusuen (Lundun Allianie Publishers Lid. 1980). p 8

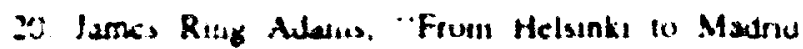
in Human Righis in Our Time. Essess in Memuin of Vicker Buras, ed Masc ff Plalines (Boulder and London Vestrien Prews, 19851, p 118

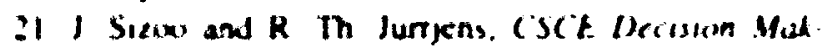

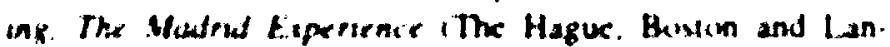

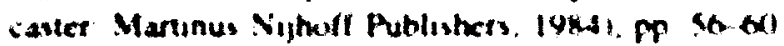

:2 thas o o

23 Marckia. 154

it is Departiment of Stale, The Arigriade Followusp

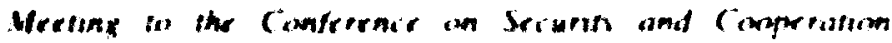

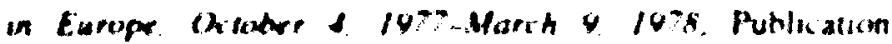
t) Washungton Department of State 19781. m 3.h

25 Nkheri B Wall. "Overteaction to Croldhet" in Vojtech Mastny. ad Helirily. Human Rights and Europran Secuntr. "Durthem Duke Iniveroin Press. 19861. Mn 16?100

is Camtll Sherer. "Breakdoun at Belgrade." Wiash

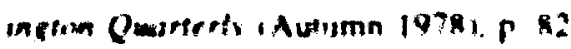

$\because$ COCF Puthe Sasiemones. is

ar Ian Madprald. "The Hicar Consencus" in Maseny. Heitindi and Eumpran Sriurth. isen

av ind 1 to 
30. Interview with Ambassador Warren Zimmermann, September 4, 1987

31. US Congress, Commission on Securily and Cooperation in Europe. The Belgrade Followup Meering to the Conference on Securin and Cexoperation in Europe: A Report and Appraisul (Washington: Government Printing Office, 1978). p \&

32 Commission on Skiurnt and Ceroperalion in Eu. rope. Washinglon, DC 20515

33 Rober Lyle, "The Administration', Objations" in Masiny. Helsinki and European Securn! 117

34 US Deparment of State. Secund Semalnnual Repant to the Commession on Secunn und Cixpperuthon in Europe. lecemhs, : 1970 June 1. 1977. Publication 34 (Wiashing. ton Department of Scate. 1977). p 1

35 H Gordun Skilling. "Chanter 77 Declaration. Praque. lanuary 1. $1977^{\circ}$ in Masiny. Helsinhs and Europrean Securin. 10) $3-105$

16 US Department of State. Sectond Semunnnual Re. port. 6

37 lbud

3 B Bulletin (May 23, 1979, cos Sox

19 is Congerss. Belereade Follem up Meering. S

4) Us Congress. Commision in Scrurity and (io. operation in Europe. Impirmentotion of the timal Alt of

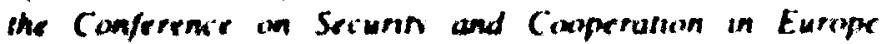

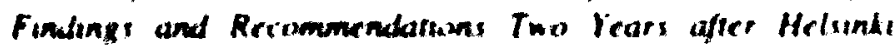
(Washingion Covernment Phnting Office. 1977). p A

$\$$ Danic B Faucell. "Dnd Human Righis Survive Bcl. grade" Forvien Polac iSummer 19781 of 104-118

t? US Congress. Aelgrude Fodlow up Merime. il

11 Richard Davy. "Procedural Wirangles in Belgrade."

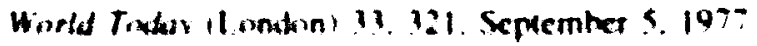

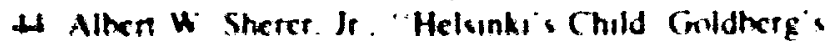
Visiation." Forrign Pollow isummer 19km, p ist

45 Carroll Sherer. $81-92$ 


\section{THE HELSINKI PROCESS}

46. Bulletin (June 27, 1977) p. 677

47. Arthur J. Goldberg. "The Helsinki Final Act and the Madrid Review Conference: A Case Study of Political Non-Communication." Political Communication and Persuasion, 2, 1, 1982, pp. 1-19

48. US Congress, Belgrade Followup Meeting. 13

49. Fascell, 111. For a contrary view, see J.E.S. Fawcell. "The Belgrade Conference: Recycled Paper?" Mil. lennium: Joumal of International Studies (Spring 1978), pp. 52-59. Fawcett argues that "while Principle VI refers specifically to forms of intervention involving the use or threat of force." it also precludes "political, economic or other coercion designed ... to secure advantages of any kind." He concludes "that the manner in which human rights issues were raised at the Belgrade conference was a wrong tactic. that diplomatic action in various contexts is an alternative and more effective course for governments, and that it at least should be pursued in anticipation of the Madrid conference. if the Final Act is to make progress."

50. US Congress, Belgrade Followup Meering. 16

51. Alben W. Sherer. If. "Inevilable Disappointment," Foreign Policy (Summer 1980), pp. 156-159

52. US Deparment of State, Belgrade Followup Meeting. $17-20$

53. Viadimir Lomeiko. "Realities and Prospects of Detente is Seen in Moscow after the Belgrade Experience" in The Belgrade Conference: Progress or Regression-East. em. Westem, and Non-Aligned Appraisals of an Unfinished Conference. ed. Comelis $C$. van den Heuvel and Rio d. Praaning (Leiden: New Rhine Publishers. 1978). pp. 23-37

54. US Deparment of Siate. Belgrade Followup Meet. ing. 33

55. Ian MacDonald. "A Small Harvest" in Mastny. Helsinki and European Security, 178

56. US Department of State. Belgrade Followup Meet. ing. 35 
57. CSCE Public Statements, 158-204

58. US Congress, Commission on Security and Cooperation in Europe, Fulfilling Our Promises: The United States and the Helsinki Final Act (Washington: Government Printing Office, 1979)

59. US Department of State, Ninth Semiannual Report, Implementation of the Helsinki Accord, June I, 1980-No. vember 30, 1980 (Washington: Department of State, 1980), p. 5

60. Ibid., 6

61. Ibid., 6-7

62. Ibid., 18

63. Public Papers of the Presidents of the United Stuses: Jimmy Carter, 1980 (Washington: Government Printing Office, 1982), pp. 1434-1435

64. Robert Rand, "America's Helsinki Lobby" in Mastny, Helsinki and European Security. 197

65. H. Gordon Skilling, "CSCE in Madrid," Problems of Communism (July-August 1981), p. 8

66. US Congress. Commission on Security and Cooperation in Europe. The Madrid CSCE Review Meeting (Washington: Commission on Security and Cooperation in Europe. 1983). pp. 1-2

67. US Department of State, Ninth Semiannual Report, 2

68. Ibid.

69. Roland Eggleston, "The Conference Finally Opens" in Mastny. Helsinki and European Security. 205206

70. US Deparment of State. Ninth Semiannual Report. 2

71. US Congress. Commission on Security and COoperation in Europe. The Madrid CSCE Review Meeting: An Interim Report. January 6. 1981 (Washington: Commission on Security and Cooperation in Europe, 1981). p. 2 72. Ibid.

73. Ibid.. 10-11

74. Ibid., II 


\section{THE HELSINKI PROCESS}

75. Ibid.

76. Ibid., 13

77. Ibid., 14-15

78. Ibid., 18

79. Ibid., 16

80. Skilling, 10

81. US Congress, Madrid Interim Report, 17

82. Ibid., 17-18

83. Ibid., 7

84. Three Years at the East West Divide, ed. Leonard R. Sussman (New York: Freedom House, Inc., 1983), p. 13

85. Dante B. Fascell, "The Madrid CSCE Meeting," Washington Quarterly 5 (Autumn 1982), p. 202

86. US Congress, Madrid Interim Reporn, 14

87. Skilling, 13

88. US Congress, Madrid Interim Report, 18-19

89. Three Years at the East West Divide, 30-31

90. US Department of State, Eleventh Semiannual Reporn. 3

91. US Congress, Commission on Security and Cooperation in Europe. The Madrid CSCE Review Meeting: Phose III Interim Report, January 8, 1982 (Washington: Commission on Security and Cooperation in Europe, 1982), p. 6

92. Alexander Haig. "We Are at a Critical Crossroads" in Mastny, Helsinki and European Security, 230

93. US Congress. Commission on Security and Cooperation in Europe. The Madrid CSCE Review Meeting: Phase IV Interim Repon, March 23, 1982 (Washington: Commission on Security and Cooperation in Europe, 1982). p. 1

94. Ibid., 1-2

95. Roland Eggleston. "The Eloquent Silences" in Mastny. Helsinki and European Security, 248

96. Edward L. Killham, "The Madrid CSCE Conference." World Affairs, p. 345 
97. Ibid., 346-347

98. Ibid., 347

99. Sizoo and Jurrjens, 240-241

100. Roland Eggleston, "A Matter of Words" in Mastny, Helsinki and European Security, 263

101. Roland Eggleston, "Qualified US Agreement" in Mastny, Helsinki and European Security, 268

102. Killham, 349

103. US Congress, Madrid CSCE Review Meeting, 6 104. William Korey, "End of the Marathon, A Kind of Victory in Madrid," The New Leader 66 (August 822, 1983), pp. 6-8

105. Bulletin (October 1983), 50-52

106. Andrei Gromyko, "The Madrid Meeting, The South Korean Plane Destruction," Vital Speeches of the Day, 49, 24, Oct. 1, 1983

107. Roland Eggleston, "A Fairly Substantial Document" in Mastny, Helsinki and European Security. 270

108. US Department of State, Fifteenth Semiannual Report, Implementation of Helsinki Final Act, June 1, 1983November 30, 1983 (Washington: Department of State. 1983). pp. 3-4

109. US Congress. Madrid CSCE Review Meeting, 8 110. Ibid., 9

111. Bulletin (February 1985), 5-6

112. Bulletin (March 1984), 34-36

113. Ibid., 34-36

114. Bulletin (February 1985), 6

115. Ibid.

116. US Department of State, Sixteenth Semiannual Report. Implementation of Helsinki Final Act. December I. 1983-March 31. 1984 (Washington: Department of State. 1984), p. 3

117. Richard E. Darilek, "Building Confidence and Security in Europe: The Road to and from Stockholm." Washington Quarterly (Winter 1985) 


\section{THE HELSINKI PROCESS}

118. US Department of State, Seventeenth Semiannual Report. Implementation of Helsinki Final Act, April 1, 1984 October 1, 1984 (Washington: Department of State, 1984), p. 3

119. Ibid., 4

120. US Department of State, Eighteenth Semiannual Report. Implementation of Helsinki Final Act. October I. 1984-April I. 1985 (Washington: Department of State, 1985), p. 3

121. US Department of State, Nineteenth Semiannual Report, Implementation of Helsinki Final Act, April 1. 1985October 1. 1985 (Washington: Deparment of State, 1985), p. 3

122. John Borawski, Stan Weeks, and Charlotte E. Thompson, "The Stockholm Agreement 1986," Orbis (Win(er 1987), pp. 650-651

123. US Department of State. Twentieth Semiannual Reporn, Implementation of Helsinki Final Act, October I. 1985-April I. 1986 (Washington: Department of State. 1986), 3

124. Bulletin (January 1986), 9

125. Twentieth Semiannual Reporn, 4

126. Borawski. Weeks, and Thompson. 652

127. Ibid.

128. Bulletin (September 1986), 43-44

129. Borawski. Weeks, and Thompson, 653-654

130. Ibid.. 655

131. John Borawski, "Accord at Stockholm," Bulletin of Atomic Scientists (December 1986), p. 34-36

132. US Deparment of State. Twenty-First Semiannual Report. Implementation of Helsinki Final Act, April 1. 1986October 1. 1986 (Washington: Department of State, 1986). p. 4

133. CSCE Public Statements, 419-426

134. Ibid. $417-418$ 
135. Weekly Compilation of Presidential Documents, 22, 39. pp. 1239-1240

136. Nineteenth Semiannual Report, 4

137. CSCE Public Statements, 284-285

138. Roland Eggleston, "Clash at Ottawa" in Mastny, Helsinki and European Security, 279-282

139. US Department of State, Country Reports on Human Rights Practices in 1981 (Washington: Government Printing Office, 1982), p. 6

140. CSCE Public Statements, 308

141. Nineteenth Semiannual Reporn, 5

142. Norman St. John Stevas, "The Ars, the Individual, and Society," in Mastny, Helsinki and European Security, 313

143. Mihajlo Mihajlov, "Differing Conceptions of Culture" in Mastny, Helsinki and European Security, 312

144. Twentieth Semiannual Reporn, 4-5

145. Soviet Committee for European Security and Cooperation. "The Helsinki Process 87." Report on Fulfillment of the Provisions of the European Conference's Final Act (Moscow: Soviet Committee for European Security and Cooperation. 1987). p. 71

146. CSCE Public Statements, 332-336

147. Twenty-First Semiannual Report. 4-5

148. CSCE Public Statements. 374-38!

149. Ibid.

150. "Helsinki Process 87." $41-42$

151. Weekly Compilation of Presidential Documents. 22. 32. pp. $1022-1023$

152. Verbatim record of the opening statements 4-7 November 1986. "Vienna Meeting 1986 of Representatives of the Participating States of the Conference on Security and Cooperation in Europe Held on the Basis of the Provisions of the Final Act Relating to the Follow. Up to the Conference." CSCE/WT. Vienna, 4 November 1986. pp. 2-6 


\section{THE HELSINKI PROCESS}

153. Ibid., 14

154. Ibid., 37-38

155. Ibid., $31-42$

156. Ibid., 40-47. See also US Congress, Commission on Security and Cooperation in Europe, The Vienna CSCE Follow-Up Meeting (Washington: Government Printing Office, 1990), p. 45

157. Ibid., 11-14

158. US Congress, Commission on Security and Cooperation in Europe. Phase I of the Review Meeting of the Conference on Security and Cooperation in Europe, November 4-December 20, 1986 (Washington: Government Printing Office. 1987), p. 3

159. Ibid., 8

160. Ibid.

161. Ibid., I

162. luid., 13

163. Statement by Vladimir Morozov, Member of the USSR Delegation at the Vienna Meeting. November 14, 1986. unpublished

164. Phase I Vienna, 16-17

165. Ibid., 17

166. "Helsinki Process 87," 33

167. US Congress, Commission on Security and Cooperation in Europe. The Vienna Review Meeting of the Conference on Security and Cooperation in Europe. Compilation of Speeches November 4. 1986-December 20, 1986 (Washington: Government Printing Office. 1987), p. 283

168. Phase I Vienna. 18

169. Ibid.. 21

170. Washington Post. S splember 2. 1987, p. A23

171. Phase I Vienna. 21

172. Ibid.. 22

173. Ibid. 24

174. Ibid.

175. Ibid.. 25 
176. “Helsinki Process 87," 77-78

177. Phase I Vienna, 25

178. Statement by Laurence O'Keeffe, Leader of the United Kingdom Delegation at the Vienna Meeting, 6 March 1987, unpublished

179. Statement by Ambassador Yuri Kashlev, Head of the USSR Delegation at the Vienna Meeting, February 3, 1987, unpublished

180. US Congress, Commission on Security and Cooperation in Europe, Phase II of the Vienna Review Meeting of the Conference on Security and Cooperation in Europe, January 27-April 10, 1987 (Washington: Government Printing Office, 1987), p. ' 4

181. lbid., 8

182. Statement by Ambassador Ekkehard Eickoff, Chairman of the Delegation of the Federal Republic of Germany, on behalf of the European Community at the Vienna Meeting, 18 February 1987, unpublished

183. Phase II Vienna, 15

184. Ibid., 19-20

185. Ibid., 17

186. Ibid., 18

187. Statement by A.G. Kovalev, First Deputy Foreign Minister of the USSR at the Vienna Meeting, January 30 , 1987, unpublished

188. Statement by Ambassador Yuri Kashlev, Head of the USSR Delegation at the Vienna Meeting, 10 July 1987. unpublished

189. Statement by Ambassador Warren Zimmermann, Chairman of the US Delegation at the Vienna Meeting, July 31, 1987, unpublished

190. Statement by Ambassador Curt Lidgard. Head of the Swedish Delegation at the Vienna Meeting, 31 July 1987. unpublished

191. "NATO Military Security Proposal, CSCE/WT 129. Vienna." 10 Iuly 1987. unpublished 


\section{THE HELSINKI PROCESS}

192. William R. Bowman, Limiting Conventional Forces in Europe (Washington: National Defense University Press, 1985), pp. 73-74

193. US Congress. Commission on Security and Cooperation in Europe, Phases III and IV of the Vienna Review Meeting of the Conference on Security and Cooperation in Europe, May 5-July 31, 1987 and September 22-December 18, 1987 (Washington: Government Printing Office, 1988), pp. 33-34

194. Statement by Ambassador Warren Zimmermann, Chairman of the US Delegation at the Vienna Meeting, November 20, 1987, unpublished

195. Statement by Ambassador Warren Zimmermann, Chairman of the US Delegation at the Vienna Meeting, March 22, 1988, unpublished

196. New York Times, March 27, 1988, p. A6

197. "Helsinki Process 87," 10-11

198. US Congress, Commission on Security and Cooperation in Europe, Hearings (Washington: Government Printing Office, 1986), pp. 23-24

199. Ambassador Zimmermann, statement, March 22, 1988

200. New York Times, March 27, 1988, p. A6

201. Vienna CSCE Follow-Up Meeting, 21

202. Ibid.

203. Ibid., 2

204. Ibid., 4

205. Ibid., 143

206. US Congress, Commission on Security and Cooperation in Europe, Report of the Meeting on the Protec. tion of the Environment of the Conference on Security and Cooperation in Europe (Washington: Government Printing Office, 1991)

207. US Congress, Commission on Security and Cooperation in Europe, Copenhagen CSCE Meeting on the 
Human Dimension, Hearings (Washington: Government Printing Office, 1990), p. 40

208. US Congress, Commission on Security and Cooperation in Europe. Document of the Bonn Conference on Economic Cooperation in Europe (Washington: Government Printing Office, 1990)

209. US Congress, Commission on Security and Cooperation in Europe, CSCE Digest March 1989 (Washington: Government Printing Office, 1989)

210. US Department of State. Twenty-Seventh Semiannual Report to the Commission on Security and Coopera. tion in Europe. April 1, 1989-September 30, 1989, Special Report 183 (Washington: Department of State, 1989). pp. 6-7

211. US Department of State. President's 29th CSCE Report. "Implementation of the Helsinki Final Act, April 1. 1990-March 31, 1991" (Washington: Department of State, 1991), p. 9

212. CSCE Digest March 1989

213. US Department of State. "Proposals for a Free and Peaceful Europe," Address by President Bush at Rheingoldhalle. Mainz. Federal Republic of Germany. May 31, 1989 (Washington: Department of State, 1989)

214. CSCE Digest August 1989

215. US Department of State. "From Revolution to Democracy: Central and Eastern Europe in the New Europe." Address by Secretary of State Baker at Prague. Czechoslovakia February 7, 1990 (Washington: Department of State. 1990)

216. US Department of State. "CSCE: The Power of Principle." Remarks by President Bush at the CSCE Ministerial in New York. October 1, 1990 (Washington: Department of State. 1990)

217. US Congress. Commission on Securiny and Cooperation in Europe. Charter of Paris for a New Europe (Washington: Government Printing Office. 1990) 


\section{THE HELSINKI PROCESS}

218. Vienna CSCE Follow-Up Meeting, 5

219. US Congress, Commission on Security and Cooperation in Europe. Paris Human Dimension Meeting (Washington: Government Printing Office, 1990), p. 76 220. "Proposals for a Free and Peaceful Europe" 221. Paris Human Dimension Meeting, 82-83

222. US Congress, Commission on Securin and Cooperation in Europe. The Copenhagen Meeting of the Conference on the Human Dimension. 5 June-29 June 1990: Staff Reporn (Washington: Government Printing Office. 1990), pp. 12-13

223. Ibid., 16

224. Copenhagen CSCE Meeting: Hearings, 81

225. Ibid., 51

226. The Copenhagen Meering: Sraff Report. 34

227. Copenhagen CSCE Meeting: Hearings. 3

228. CSCE Digest December 1989

229. "From Revolution to Democracy: Cenural and Eastern Europe in the New Europe"

230. US Department of State. "NATO and the US Commitment to Europe." Address by President Bush at Stillwater. Oklahoma, May 4. 1990 (Washington: Depart. ment of State. 1990)

231. US Department of State. "CSCE: Bulding Together for the Future." Address by Secretary of State Baker at the CSCE Minisierial in New York. October 1, 1990 (Washington: Depertment of State, 1990)

232. Intemational Herald Tribune. September 28, 1990

233. CSCE Digest December 1990

234. New Yort Times. November 22. 1990, p. A17

235. US Depertment of State. "CSCE: Putting Principles Into Practice." Remarks by President Bush at the CSCE Conference. Paris. November 19. 1990. (Washington: Deparment of Sule. 1990)

236. Vienna CSCE Follow Up Meeting (1)

237. CSCE Digest December 1989 
238. Washington Post, June 5, 1988, p. A27

239. US Congress, Senate Committee on Foreign Relatuons, Lessons of the Helsinki Process for the New World Order, March 14, 1991 (Washington: Govemment Printing Office, 1991), p. 15

240. Leonard R. Sussman. "In Suppont of the Helsinki Process," Freedom at lssue (September-October 1985), pp. 14-17

241. Ambassador Zimmermann, statement, November 20, 1987

242. Ibid.

243. Maresca. "To Helsinki," 222

244. US Department of State, Dispatch. November II. 1991 (Washington: Deparment of State, 1991), p. 827

245. CSCE Digest Summer 1991

246. CSIS-FIIA. Conference on Security and Coopera. tion in Europe: The Nexi Phase. Kate Holder, Rober Hunter, and Pavo Lipponen, editors (Washington: The Center for Strategic and International Studies, 1990). p. 11

247. US Department of State, Dispatch. November 11. 1991.826

248. CSCE Digest April 1991

249. CSCE Public Stasements, 100 


\section{Index}

Abran. Morns, 151

Adams, James Ring. 14

Amencan Indians, 44

Andropov, Yuri, 69.82

Antall, József. 165

Anti-ballistic missiles, 122

Anti-Semitusm, 46, 52, 57, 151

Arbitration rules, 16

Arms conerol and disarmament. 8, 37, 63, 65, 73-74. 79-91

SALT 11. 88-89, 122

See also Mutual and Balanced Force Reduction

Baker, James. 147-149

Pans Charter. 157

Baltic states. 10, 54, 171-172

Barmy. Roben. 85. 90

Basket 1. 13, 15, 52. 65-66. $122-123,136.139$

Basket II. 15-16. 4. 55, 63. 65-66.141.144

Vienna proposals. 119

Baskel III. 17. 57. 59. 64. 66. 126. 135, 136, 139

See also Family reunification BBC. 46. 59

Belgrade meeting. 23-41, 107. 136

post-meeting working groups. 37-38

Bell. Griffen. 47
Bern conference, 101-104, :36

Binational marnages See Marriages

Bindschedler, Rudolf, 24

Bogomolny. Benjamin. 108

Bonner. Yelena. 93

Bourgeois nationalism. 99

Buwman, William. 131

Brailovsky. Vladimir, 56

Brezhnev. Leonid. 8

address to 23rd Pany Congress. 4

death. 69

Final Act and. 12

Helsinki Process and, 167

Moscow summit. 1972. 6

pre-Belgrade military proposal. 37

Budapest conference. 98-101

Buergenthal. Thomas, 154, 155

Bums, Tom, 61-62

Bush, George

CFE negotiations, 148-150

on Easiem Europe. 152

on Helsinkj Process. 170

Paris Charter. 156-157. 159.

163

Calcin-Dumitreasa, Gheorghe. 95

Carter. Jimmy

Belgrade and human rights. 23-24, 29-30, 33 
THE HELSINKI PROCESS

departure from office, 61

Madrid meeting, 47

post-Belgrade actions, 43-44

CDE. See Conference on Confidence- and Security-Building Measures and Disarmament in Europe

Ceausescu, Nikolai, 137, 165

Censorship, 115-116

CFE. See Conventional Armed Forces in Europe

Charter 77, 24, 28-29, 134

Charter of Paris, 156-163

Chemenko, Konstantin. 69, 82. 85

Chernobyl nuclear accident, 114,124

Christopher. Warren, 33

Citron. Klaws, 87

Civil rights. 14, 43-44, 96-97. 122-123

Cold War. 9, 35, 53, 160

Commission on Security and Cooperation in Europe. 26

Committce for the Defence of the Unjustly Persecuted. 29

Committee on Worker's SelfDefense, 29

Conference on Confidence- and Security-Building Measures and Disarmament in Europe, 63, 65-66, 7991, 79, 83, 86, 90, 130

Vienna meeting proposal, $118-119$
Conference on Economic Cooperation in Europe, 143, 144

Conference on Military Detente and Disarmament in Europe, 63

Conference on the Human Dimension, 143, 150-156

Confidence- and security-building measures, 15, 38 . 54-55. 65-66, 73-74, 145-150, 169

Soviet proposals, 85-86

Stockholm proposals, $80-81$. 85-86

Vienna meeting. $110-111$. 129-133, 139

zone of application. 89

Confinement violations, 125

Congress. United States. 26

Consensus rule, 19-20

Conventional armed forces. 119 , 121-122, 137, 147-150. 159, 160, 169

Conventional Armed Forces in Europe, 147-150, 159. 160, 161. 169

Conventional forces reduction, 119. 121-122, 148-150

Copenhagen meeting, 153-156

Cruise missile deployment to Europe, 84

CSBMs. See Confidence- and security-building measures

Cultural cooperation, 9, 17-18. 41. 43-44, 59-60, 64 . $75,99-100,114,126$

Currency exchange, 58 
Daniloff, Nicholas, 107-108, 115

de Gaulle, Charles, 105

DeConcini, Dennis, 156

Delworh, W. T., 87

D'Estaing, Valery Giscard, 12

Detente, 13, 26, 37, 40, 62-63

human rights and, 48, 96

Deutsche Welle, 46, 59

Diplomatic missions access, 75

Disarmament. See Arms control and disarmament

Discrimination against minorities, 97-98, 100, 123 , $124-125,151$

Disputes settlement, 41,43

Dissemination of information, 17

See also Information exchange

Dissidents, 93

Hungary, 134

Soviet Union, 23, 26, 45, 56, 108

Dobrynin, Anatoly, 5

Dresser Industries, 55

Dual nationals, 125

Dubinin, Yuri, 52

Dulles, John Foster, 3

Ecoglasnost. 144

Economic cooperation, 8, 9, 14, 15. 27. 39, 41, 43-44, 63. 123, 128, 144, 172 . 173

Economic rights, 123

Education cooperation, 59-60
Educational cooperation, 18, 38, 75,126

Eickhoff, Ekkehard, 123

Electrical energy, 16

Ellemann-Jenson, Uffe, 153

Emigration, 35, 48, 57-58, 64, $74-75,93,94,102,108$, 110.138

restrictions, 114-115

See also Jewish emigration

Energy cooperation, 38, 63

Environmental cooperation, 15. $16-17,38,111,113-$ 114, 124, 143-144, 173

Equality principle. See Principle IX

Escape forward concept, 31

Eshkulov, Akverdy, 94

European Community, 67, 69

European Convention of Human Rights, 154

Exports. See Economic cooperation: International trade

Family reunification, 10, 17. 29. 30-31, 35, 38, 5658, 64, 74-75, 94-95, $102,125,140$

Fascell, Dante, 27, 135, 159. 173

Final Act, 10-21

application to other areas, 168

compliance with, 44, 49, 62 , 108

Confidence Building Measures and Certain Aspects 


\section{THE HELSINKI PROCESS}

of Security and Disarmament, 36

description, 12-13

Genscher on, 106

Gromyko on, 135

Helsinki Commission and, 26

Helsinki Lobby and, 47

human rights and, 23

humanitarian cooperation, 39

implementation, 26, 40, 49 ,

$$
\text { 57, 70-71 }
$$

Madrid provisions and, 74-75 monitoring groups and, 28

Principles, 52-53, 62

scope of, 13-14

security confidence-building provisions, 55

Shultz on, 106

Soviet invasion of Afghanistan and, 46

trade unions, 75

Ford, Gerald, 10-11

Helsinki Commission, 26-27

Helsinki meeting, 173

on human rights, 14

Four Great Powers, 3

Quadripartite Agreement on Berlin, 6

Free movement, 6, 9, 10-11, $17,27,57,64,102,125$, 139

See also Emigration

Freedom of artistic expression, 114

Freedom of speech, 97-98, 115

Freedom to labor, 38-39

Freidlin, Mark, 113
Genscher, Hans-Dietrich, 106 German Pentecostal Church, 93 German reunification, 4, 8-9 Ginzberg, Aleksandr, 60 Glasnost, 117, 127-128

Goldberg, Arthur, 23-25, 33 35, 39

Gonzalez, Felipe, 71

Goodby, James, 79, 81, 85

Gorbachev, Mikhail

CFE negotiations, 148-149

Geneva meeting with Reagan, 102

glasnost, $117,127-128$

Helsinki Process and, 166167

Moscow meeting with Reagan, 18, 137

on Jewish emigration, 133

"openness" campaign, 110

Paris Charter, 156

Reykjavik meeting, 106-107

Sakharov and, 109

Stockholm conference, 85-86

Grigorenko, Pyotr, 60

Grinevsky, Oleg, 87

Gromyko, Andrei, 72, 82

on Helsinki Process, 135

Haig, Alexander, 66-67

Hannibalsson, Jon Baldvin, 153

Harmel, Pierre, 4

Havel, Vaclav, 29, 151, 165

Helsinki Commission, 25-28, 103,135

Helsinki Lobby, 47-48

Helsinki Monitoring Groups, 28-29 
Honecker, Erich, 165

Howe, Geoffrey, 105

Hoyer, Steny, 115. 156

Human dimension, 150-156

Human rights, 9, 10-11, 21, 38, $69,73,89,169$

as American foreign policy, $24,30,33$

Belgrade meeting and, 23-25, $29-30,33,34-36,39-40$

definition, 14-16, 96-97

detente linkage, 48

human rights documents, 154

Madrid provisions, 74-75

Ottawa conference, 95-98

post-Belgrade. $44-46$

proposal for Moscow conference, $120-121$

Romania, 138

Soviet Union, 23-25, 38, 109-110, 116-117

UN International Covenants on Human Rights, 110

United States role in, 170

US Helsinki Commission and, 26

Vienna meetings, 116-118, 122-123, 134-135

Human rights violations

Czechoslovakia, 29, 34-35, $51,53,109$

East Europe, 34-35

Poland, 29, 66-69

Romania, 95

Soviet Union, 28, 34-35, 44 $47,51,52,53,56,109$ 110

United States, 35-36, 53
Iiyichev, Leonid, 52, 62

Imports. See Economic cooperation; International trade

Individual rights, 74

Industrial cooperation, 15, 16 , $111,112,128$

Information exchange, 17, 30$31,56-57,64,75,100$, 125-126

Inspection of military installations, 87, 88-89, 90, 132

Intermediate range nuclear missiles, 70, 83-84

Internal affairs interference, 23 , $52,53,54,57$

International Atomic Energy Age..cy, 113-114

International Covenants on Human Rights, 154

International Human Rights Day, 108,120

International trade, 15-16, 1111112

Irlin, Joseph, 113

Jackson-Vanik amendment, 112

Jewish emigration, $30,57,58$, $93,94,133$

John Paul II, 95

Joint Declaration of TwentyTwo States, 160

Joint ventures, 112,128

Journalists

Madrid conference, 60-62

treatment of, $10,17,38,59$, $69,75,76$ 


\section{THE HELSINKI PROCESS}

See also Media; Radio broadcasts

Kampelman, Max, 47, 61, 65 , 68. 153

on Middle East, 167-168

Kashlev, Yuri, 137, 166-167 glasnost and perestroika, 128 security proposals, 121-122

Killham, Edward, 71

Kinast, Jan, 118

Kissinger, Henry, 8

Helsinki Commission, 27

Koivisto, Mauno, 166

Kondrashev, Sergei, 101

Korean airliner downing, 72

Korey, William, 72

Kovalev, Anatoly, 69, 71, 127 proposal for Moscow conference, 120

Kukk, Juri, 56

Kuznetsov, Eduard, 60

Lederer, Jiri, 29

Lewis, Flora, 60-61

Lidgard, Curt, 130

Llorca, Jose Pedro Perez, 4950

Lomeiko, Vladimir, 38

London Information Forum, 143

Luxmoore, Jonathan, 13

Madrid Concluding Document, $108,130,161$

Madrid meeting, 43-77, 136. 107 format, 50-51

Helsinki Lobby and, 47

preparatory meeting, 48-49

Marchenko, Anatoly, 108-109

Maresca, John, 21, 145-146

Marriages, 10, 17, 38, 57, 74 . 102

Martens, Wilfried, 163

Martial law, 66, 67

Masaryk, Tomas, 134

Matheny, John, 132

MBFR. See Mutual and Balanced Force Reduction

McCarran-Walter Act of 1952 , 115

Media

Belgrade meeting, 31, 34, 39

Budapest meeting, 100

Madrid meeting. 60-61

post-Belgrade radio broadcasts, 46

Vienna meeting, 116-118

See also Joumalists; Radio broadcasts

Mediterranean cooperation, 19$20,41,43,71-72,75$, 143

Migrant labor, 63

Military detente, 37-38

Military exercises, 15, 36-37, $80-81,87,88-90,118-$ $119,132,145-147$

Military forces information, 80

Military inspections, 147

Military security, 145-150

implementation of, 54

Swedish proposals at Vienna, 130-131

Minic, Milos, 34 
Minority rights, 123-125, 151, 156, 173

Mitterand, Francois. 151

Molotov, Vyacheslav, 3-4

Molotov-Ribbentrop Pact, 54

Monitoring groups, 28-29, 34 $35,45,48,52,62,74$, 125

Soviet Union, 45, 53, 108

Moscow Monitoring Group. 45, $48,53,108$

Most-favored-nation status, 55

Multimodal transport operations, 16

Musicians' Union, Czechoslovakia, 114

Muslims, 94

Mutual and Balanced Force Reduction, 6-7, 9, 73-74, 129,169

Nadgorniy, Edward, 113

Nationalism, 99

New York Times, 60

Nixon, Richard, 6

Non-intervention in internal affairs, 23

Non-use of force, $82,85,89$

Non-use of nuclear weapons, $37,82,85$

North Atlantic Cooperation Council, 172

North Atlantic Council, 5

North Atlantic Treaty Organization, 3, 19

Belgrade meeting, 32, 35-36, 38-40

Dulles on, 3
Gernuanys relationship, 3, 7

Harmel Report, 4-5

human rights and, 39-40

intermediate range nuclear missiles, 83

London summit, 157-158

Paris summit proposals, 158

Quadripartite Agreement on Berlin, 6

Vienna proposal on military security, 128-132

Warsaw Pact initiative, 5-6

Yellow Book, 49

Novak, Michael, 103

Nuclear energy research, 16

Nuclear weapons, 37, 83

O'Keeffe, Laurence, 121

Oliver, R. Spencer, 53

Olympic Games, Moscow, 45, 48

Orlov, Yuri, 28, 29, 93, 135, 168-169

release, $107-108$

Ottawa conference, 95-98

Palma de Mallorca meeting. 143

Paris conference, 143, 150-152

Pavlicek, Frantisek, 29

Peaceful Settlement of Disputes Meeting, 43

Pell, Claiborne, 31, 106

Pentagonal, 155

Perestroika, 127-128

Persian Gulf crisis, 163 


\section{THE HELSINKI PROCESS}

Political prisoners, 43-46, 93$95,133-134,151$

Soviet Union, 110

Political rights, 7, 14, 43-44. 96-97, 122-123

Postal services, 125,140

Poveny, 110

Powell, Colin, 146

Principle VI, 15, 35

Principle VII, 13-14, 15, 23. 28, 53-54, 96, 107, 109

See also Human rights

Principle VIII, 53-54

Principle IX. 18-19. 46

Prisoners of conscience. $107-$ 108, 133

Protectionism, 55

Purple Book, 84
Quadripartite Agreement on Berlin, 6

Racism. 110

Radio broadcasts, 46, 59, 64 . 76. 137-138, 140

Radio Free Europe. 59. 64

Radio Liberty. 59. 64

Raimond. Jean-Bernard. 105

Ratushinskaya. Irina. 107-108

Reagan, Ronald, 65

Geneva meeting with Gorbachev. 102

Madrid meeting. 61

Moscow summit, 18. 166

on Orlov release, 108

Reykjavik meeting, 106-107
Stockholm meeting. 84-86, 90

Vicnna meeting, 104, 137 , 140

Refuge Act of 1980, 44

Refugees, 44

Rekykjavik summit, 106-107. 112-113

Religious freedom. 14, 52, 62. $69,74,93,94,95,97-$ 98, 99-100, 102, 124 . 139. 140

Repression, 66-69

Respect for Human Rights and Fundamental Freedoms. 23

RM39. 66-70

Rotating chairmanships. 20

Sakharov, Andrei, 56, 93, 109 suppor from foreign scientists, 113

SALT II, 88-89, 122

Schifter, Richard, 96, 98

Schmidt. Helmut, 12

Scientific cooperation, 18, 41. 43-44, 56-57. 63, 111 . 112. 123-124

Scientific Forum, 43

Shcharansky. Natan, 93. 135. 168-169

Sherer, Arthur, 31, 33, 36

Shevardnadze, Eduard, 106-107 proposal for Moscow conference, 120

Shultz, George. 72

Stockholm meeting. 80 
Vienna meeting, 106. 139, Trade unions, 67, 09, 75, 102 140,143

Social rights. 14, 97, 123

Socialism. 53

Sofia Meeting on Protection of the Environment. 143144

Solinskii, Vsevolod, $96-98$

Solidarity, 29,67, 134, 165

Solzhenitsyn, Aleksandr, 10

Soviet Committee for European Security and Cooperation. 103. 135

Soviet Helsinki Watch, 28. 29 Special interest groups, $47-48$ Sports exchanges. 102

Stevas, Yorman St Juhn. 9899

Stockholm Ducument. 130, 132 Stoessel, Walter. 101

Strategic arms limutations. See Arms control and disarmament

Stus, Vasyl. 94

Technology comperation. 8.9. $15,63.08 .111 .112-$ 113. 123-124.172

Telecommunication services. 125. 110

Terronsm. 62, 75, 89. 122. 140

Thatcher. Margaret. 159-160

Tindemans. Leo. 67

Torovsky, Rudolf. 139

Tourism. 12. 17. 102

Trade Agreement Act of 1979. 44

Trade agreements. 55. 64

Walesa. Lech. 67

Warsaw Pact. 5. 7. 19. 36

Vance. Cyrus

Helsinki Commission, 27

human nghts speech at liniversitv of Georgia. 30

Venfication means. 81

Vienna conference, 10s- $\mid+1$

Vienna Document. 147

Voice of Amenca. to. 59

Vorontsow. Yuli, 23-24. 35

Vranitzky. Frant. 105. 136 


\section{THE HELSINKI PROCESS}

Bern conference, 103 collupse of, 155, 161

Madrid meeting. 49, 62, 82. 83

Vienna meeting, 129

Wushingion Post. 61-62

Wilson. Harold. 12

Women's rights, 39. 15!

Yellow Book, 32, 49, 84 Youth exchanges, 102

Yugoslar crisis. 171

Zakharov, 107-108

Zhirkov, Todor, 144

Zimmermann. Warren. 8. 53-54

Marchenko and. 109

reaction to proposal for Moscow conference. 120 121

Vienna meeting. 106. 124 125. 133-134, 139

Westem security proposals, 129-130 


\section{The Author}

John Fry, a career senior Foreign Service officer of the Depantment of Stale. conducted the research for this bouk while a senior fellow at the National Defense Universily. For six years previously he served in Europe as Coun. selor of Embassy in the US Mission to the European Communities in Brussels and in the American Embassy. Slockholm. Also. he served as Director of the Office of Bilateral and Mululateral Scienufic and Technological Affairs of the Department of State and Depuly Director of the Uffice of Science and Technology of the Agency for International Development

A nalive of Uregon. Mr. Fry received his BS from the US Naval Academy and MS from the Universily of California's Scnpps Institution of Oceanography. After duty in the President's Office of Science and Technology. the retured from the Navy in 1967. to join the Vice President's staff. He retired with the rank of Minister. Counselor of the United Stutes of America in 1988. after 42 years of government service. 
THE HEISINKI PROCESS

Negotiating Security and Cooperation in Europe

Text typeset in Times Roman Book design hy Thomas C. Gill Cover an by Rhonda Story Gross

NDU Press Editors:

Thomas C. Gill and George C. Maer 